Nevada

Environmental

Restoration

Project

Corrective Action Decision Document for Corrective Action Unit 322: Areas 1 and 3 Release Sites and Injection Wells Nevada Test Site, Nevada

Controlled Copy No::

Revision No.: 0

December 2004

Approved for public release; further dissemination unlimited.

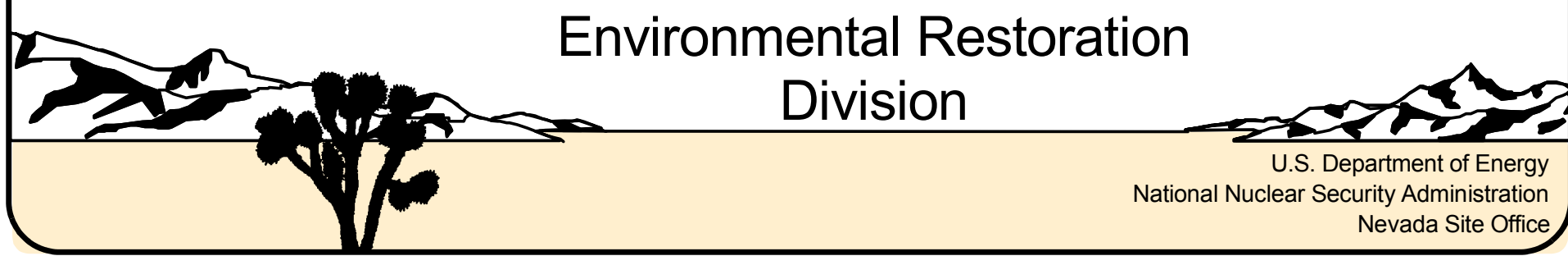


Available for public sale, in paper, from:

U.S. Department of Commerce

National Technical Information Service

5285 Port Royal Road

Springfield, VA 22161

Phone: 800.553 .6847

Fax: 703.605.6900

Email: orders@ntis.gov

Online ordering: http://www.ntis.gov/ordering.htm

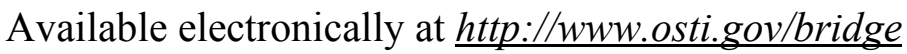

Available for a processing fee to U.S. Department of Energy and its contractors, in paper, from:

\section{U.S. Department of Energy}

Office of Scientific and Technical Information

P.O. Box 62

Oak Ridge, TN 37831-0062

Phone: 865.576 .8401

Fax: 865.576.5728

Email: reports@adonis.osti.gov

Reference herein to any specific commercial product, process, or service by trade name, trademark, manufacturer, or otherwise, does not necessarily constitute or imply its endorsement, recommendation, or favoring by the United States Government or any agency thereof or its contractors or subcontractors. 


\title{
CORRECTIVE ACTION DECISION DOCUMENT FOR CORRECTIVE ACTION UNIT 322: AREAS 1 AND 3 RELEASE SITES AND INJECTION WELLS NEVADA TEST SITE, NEVADA
}

\author{
U.S. Department of Energy \\ National Nuclear Security Administration \\ Nevada Site Office \\ Las Vegas, Nevada
}

Controlled Copy No.:

Revision No.: 0

December 2004

Approved for public release; further dissemination unlimited. 


\section{CORRECTIVE ACTION DECISION DOCUMENT \\ FOR CORRECTIVE ACTION UNIT 322: AREAS 1 AND 3 \\ RELEASE SITES AND INJECTION WELLS \\ NEVADA TEST SITE, NEVADA}

Approved by: $\frac{\text { Signature Approved }}{\begin{array}{l}\text { Janet Appenzeller-Wing, Project Manager } \\ \text { Industrial Sites Project }\end{array}}$ Date: $111 / 29 / 04$

Approved by: Signature Approved Date: 11 11/29/04

Robert M. Bangerter, Acting Division Director

Environmental Restoration Division 


\section{Table of Contents}

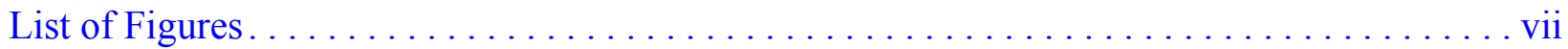

List of Tables. . . . . . . . . . . . . . . . . . . . . . . . . . . . . . . . vii

List of Acronyms and Abbreviations $\ldots \ldots \ldots \ldots \ldots \ldots \ldots \ldots \ldots \ldots \ldots \ldots \ldots \ldots \ldots \ldots \ldots \ldots$

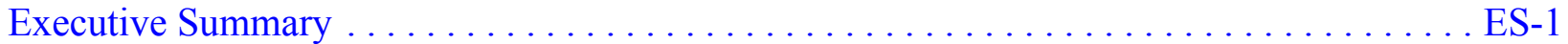

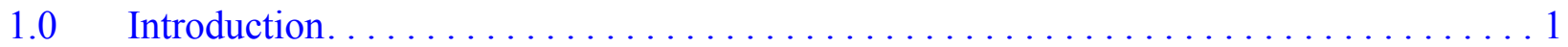

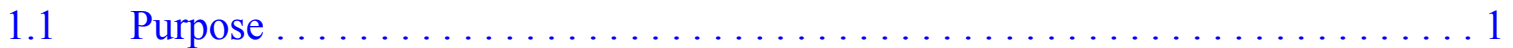

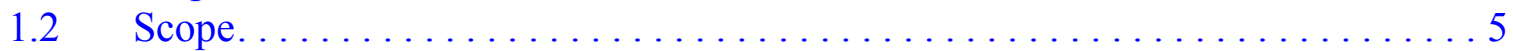

1.3 Corrective Action Decision Document Contents ..................... 5

$2.0 \quad$ Corrective Action Investigation Summary $\ldots \ldots \ldots \ldots \ldots \ldots \ldots \ldots \ldots$

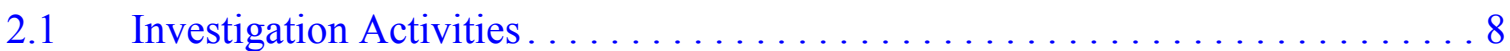

2.1.1 CAS 01-25-01, AST Release.................... 10

2.1.2 CAS 03-25-03, Mud Plant and AST Diesel Release ............ 11

2.1.2.1 CAS 03-25-03, Area A, AST Release ............. 11

2.1.2.2 CAS 03-25-03, Area B, Mud Plant .............. 11

2.1.3 CAS 03-20-05, Injection Wells . . . . . . . . . . . . . . 11

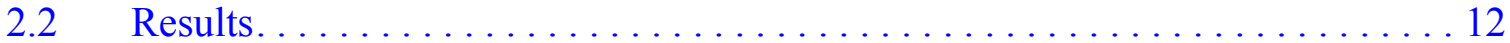

2.2.1 Summary of Characterization Data ................. 12

2.2.1.1 CAS 01-25-01, AST Release ................ 13

2.2.1.2 CAS 03-25-03, Mud Plant and AST Diesel Release .... . 14

2.2.1.2.1 Area A ......................... . . . . . .

2.2.1.2.2 Area B ..................... 15

2.2.1.3 CAS 03-20-05, Injection Wells .............. 15

2.2.2 Data Assessment Summary ........................ 18

$2.3 \quad$ Need for Corrective Action. . . . . . . . . . . . . . . . . . . . . . . . . . . 19

2.3.1 CAS 01-25-01, AST Release...................... 20

2.3.2 CAS 03-25-03, Mud Plant and AST Diesel Release........... 20

2.3.2.1 CAS 03-25-03, Area A, AST Release ............ 20

2.3.2.2 CAS 03-25-03, Area B, Mud Plant ............. 20

2.3.3 CAS 03-20-05, Injection Wells .................... 21

$3.0 \quad$ Evaluation of Alternatives . . . . . . . . . . . . . . . . . . . . . . . 22

$3.1 \quad$ Corrective Action Objectives . . . . . . . . . . . . . . . . . . . . . 22

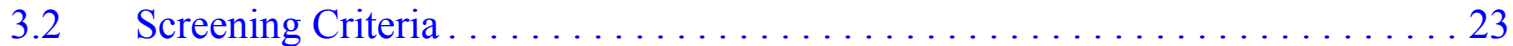

3.2.1 Corrective Action Standards ..................... 23

3.2.2 Remedy Selection Decision Factors ................... 24

3.3 Development of Corrective Action Alternatives ................. 26

3.3.1 Alternative 1 - No Further Action ...................... 27

3.3.2 Alternative 2 - Clean Closure ...................... 27

3.3.2.1 CAS 01-25-01 AST Release $\ldots \ldots \ldots \ldots \ldots \ldots \ldots . \ldots 28$ 


\section{Table of Contents (Continued)}

3.3.2.2 CAS 03-25-03 Area B, Mud Plant ............ . 28

3.3.2.3 CAS 03-20-05 Injection Wells .............. 28

3.3.3 Alternative 3 - Close in Place with Administrative Controls . . . . . . 29

3.3.3.1 CAS 01-25-01, AST Release ................. 29

3.3.3.2 CAS 03-25-03 Area B, Mud Plant................ . 30

3.3.3.3 CAS 03-20-05, Injection Wells .............. 32

3.4 Evaluation and Comparison of Alternatives. . . . . . . . . . . . . . 34

$4.0 \quad$ Recommended Alternatives . . . . . . . . . . . . . . . . . . . . . . 39

$5.0 \quad$ References..................................... 41

\section{Appendix A - Corrective Action Investigation Results for CAU 322}

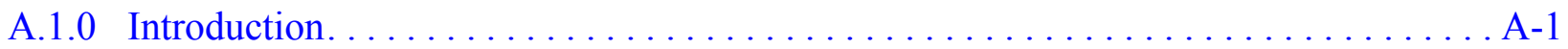

A.1.1 Project Objectives............................ A-2

A.1.2 Content ................................... A-2

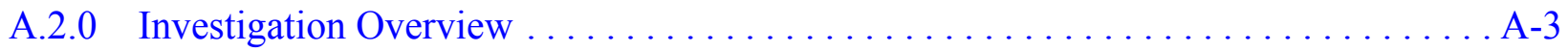

A.2.1 Preliminary Conceptual Models . . . . . . . . . . . . . . . . . . A-4

A.2.2 Sample Locations . . . . . . . . . . . . . . . . . . . . . A-4

A.2.2.1 Housekeeping Removal of Debris . . . . . . . . . . . . A-5

A.2.3 Investigation Activities . . . . . . . . . . . . . . . . .

A.2.3.1 Surface Radiological Surveys . . . . . . . . . . . . . . A-5

A.2.3.2 Site Walk-Overs. . . . . . . . . . . . . . . . . . . A-6

A.2.3.3 Field Screening . . . . . . . . . . . . . . . . . . . A-6

A.2.3.4 Surface and Subsurface Sampling ... . . . . . . . . . . A-6

A.2.3.4.1 Surface Radiological Surveys and Swiping . . . . . . . . A-7

A.2.3.4.2 Waste Characterization and Sampling . . . . . . . . . . A-7

A.2.3.4.3 Sample Location Documentation ............. A-8

A.2.4 Laboratory Analytical Information. . . . . . . . . . . . . . A-8

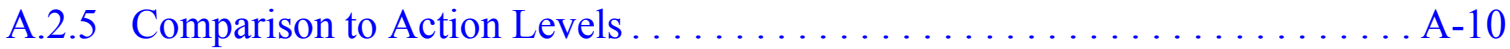

A.2.6 Geology. . . . . . . . . . . . . . . . . . . . . . . . . . A 10

A.2.7 Hydrology . . . . . . . . . . . . . . . . . . . A-10

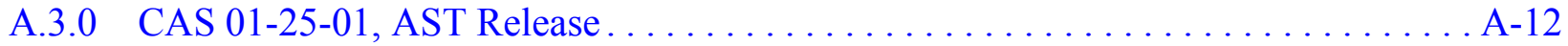

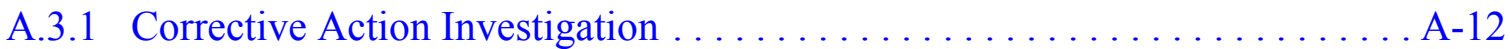

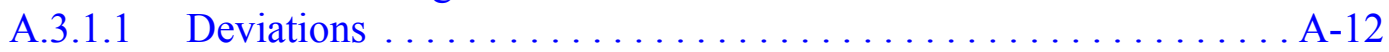

A.3.2 Investigation Results. . . . . . . . . . . . . . . . . A-15

A.3.2.1 Radiological Survey Results . . . . . . . . . . . . . . A-15

A.3.2.2 Sampling .......................... A-15 


\section{Table of Contents (Continued)}

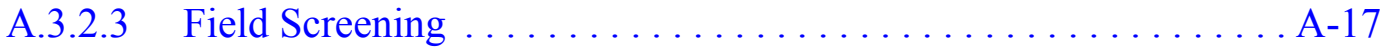

A.3.2.4 Sample Analysis ........................... A-17

A.3.2.5 Analytes Detected Above Minimum Reporting Limits......... . A-17

A.3.2.5.1 Total VOCs .......................... A-18

A.3.2.5.2 Total SVOCs ...................... A-18

A.3.2.5.3 Total RCRA Metals and Beryllium .............. A-18

A.3.2.5.4 PCBs .......................... A-18

A.3.2.5.5 TPH-GRO and TPH-DRO . .............. A-19

A.3.2.5.6 Gamma-Emitting Radionuclides ............. A-19

A.3.2.6 Contaminants of Concern . . . . . . . . . . . . . . . . A-20

A.3.3 Nature and Extent of Contamination . . . . . . . . . . . . . . . . . A-20

A.3.4 Revised Conceptual Site Model . . . . . . . . . . . . . . . . . . A-22

A.4.0 CAS 03-25-03, AST Release and Mud Plant ..................... A-25

A.4.1 Corrective Action Investigation . . . . . . . . . . . . . . . . . . . A-25

A.4.1.1 Deviations ............................. A-26

A.4.2 Investigation Results. . . . . . . . . . . . . . . . . . . . A-26

A.4.2.1 Radiological Survey Results ..................... A-26

A.4.2.2 Inspection and Sampling . . . . . . . . . . . . . . A-30

A.4.2.3 Field-Screening Results . . . . . . . . . . . . . . . A-35

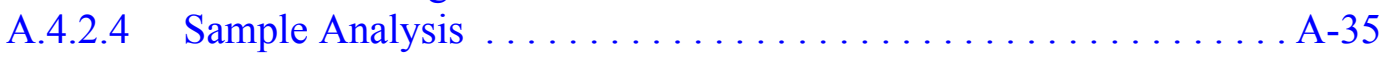

A.4.2.5 Analytes Detected Above Minimum Reporting Limits......... A-35

A.4.2.5.1 Total VOCs . . . . . . . . . . . . . . . . . . . . . . . A-36

A.4.2.5.2 Total SVOCs $\ldots \ldots \ldots \ldots \ldots \ldots \ldots \ldots \ldots \ldots \ldots . \ldots \ldots$

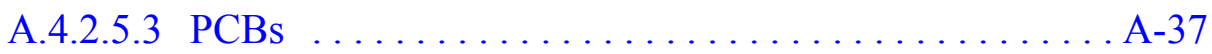

A.4.2.5.4 Total RCRA Metals and Beryllium ............ A-37

A.4.2.5.5 TPH (DRO/GRO) ....................... A-37

A.4.2.5.6 Gamma-Emitting Isotopes . . . . . . . . . . A-44

A.4.2.5.7 Strontium-90 ..................... A-46

A.4.2.5.8 Plutonium . . . . . . . . . . . . . . . . . A-46

A.4.2.5.9 Uranium . ....................... A-46

A.4.2.6 Contaminants of Concern .................... A-52

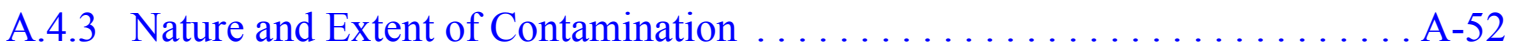

A.4.4 Revised Conceptual Site Model . . . . . . . . . . . . . . . . . . . . A-53

A.5.0 CAS 03-20-05, Injection Well . . . . . . . . . . . . . . . . . . . . . . . A A-54

A.5.1 Corrective Action Investigation . . . . . . . . . . . . . . . . A 54

A.5.1.1 Deviations ................................ A 54

A.5.2 Investigation Results............................ A-54

A.5.2.1 Radiological Survey Results ................... A-59

A.5.2.2 Inspection and Sampling ........................ A-63 


\section{Table of Contents (Continued)}

A.5.2.3 Field-Screening Results . . . . . . . . . . . . . . . . . . . A-64

A.5.2.4 Sample Analysis .............................. A-64

A.5.2.5 Analytes Detected Above Minimum Reporting Limits....... . . A-64

A.5.2.5.1 Total VOCs .............................. A-65

A.5.2.5.2 Total SVOCs ......................... A-65

A.5.2.5.3 Total RCRA Metals and Beryllium .............. A-65

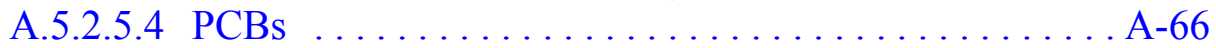

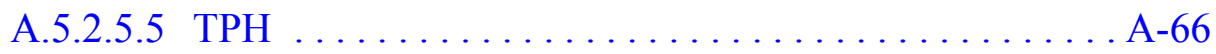

A.5.2.5.6 Gamma-Emitting Radionuclides .............. A-74

A.5.2.5.7 Plutonium ........................ A-81

A.5.2.5.8 Strontium-90 . . . . . . . . . . . . . . . . . A-82

A.5.2.5.9 Uranium ......................... A-82

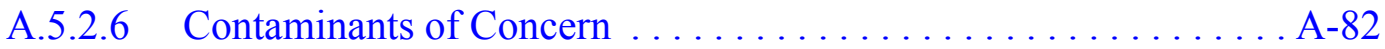

A.5.3 Nature and Extent of Contamination . . . . . . . . . . . . . . . . A-90

A.5.4 Revised Conceptual Site Model . . . . . . . . . . . . . . . . . . . . . A-91

A.6.0 Waste Management. . . . . . . . . . . . . . . . . . . . . . . . . . . A-92

A.6.1 Characterization ................................. A-93

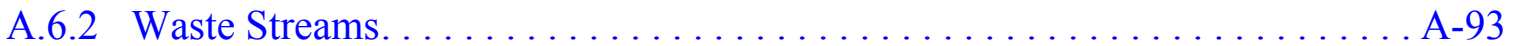

A.6.3 Investigation-derived Waste Generated $\ldots \ldots \ldots \ldots \ldots \ldots \ldots \ldots \ldots$ A-93

A.6.4 Waste Characterization Samples ...................... A-94

A.6.5 Additional Analytical Results Collected For Remediation

Waste Characterization ............................ A-94

A.6.5.1 Results for Liquid and Oil Samples. . . . . . . . . . . . . A-94

A.6.5.2 TCLP Metals ............................. A-97

A.7.0 Quality Assurance .................................... A 99

A.7.1 Data Validation............................... A-99

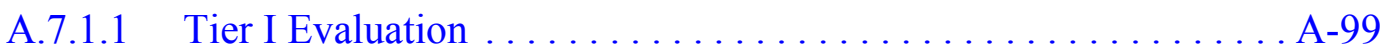

A.7.1.2 Tier II Evaluation. . . . . . . . . . . . . . . . . A-100

A.7.1.3 Tier III ................................ A-101

A.7.2 Field Quality Control Samples ...................... A-102

A.7.2.1 Field Quality Control Samples ................. A-102

A.7.2.2 Laboratory Quality Control Samples................. A-103

A.7.3 Field Nonconformances . . . . . . . . . . . . . . . . . . . . . A-103

A.7.4 Laboratory Nonconformances $\ldots \ldots \ldots \ldots \ldots \ldots \ldots \ldots \ldots \ldots \ldots \ldots \ldots \ldots \ldots \ldots$

A.8.0 Summary ...................................... A-104

A.9.0 References...................................... A-106 


\section{Table of Contents (Continued)}

\section{Appendix B - Data Assessment}

B.1.0 Data Assessment. . . . . . . . . . . . . . . . . . . . . . . . . B-1

B.1.1 Precision . . . . . . . . . . . . . . . . . . . . . . . .

B.1.1.1 Precision for Chemical Analysis . . . . . . . . . . . . . . B-2

B.1.1.2 Precision for Radiochemical Analysis. . . . . . . . . . . . . B-3

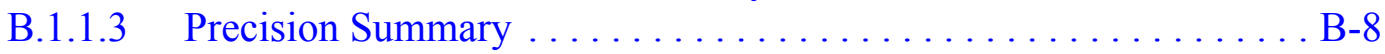

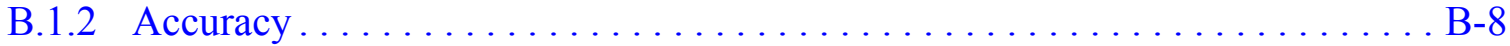

B.1.2.1 Accuracy for Chemical Analysis . . . . . . . . . . . . . . . . B-8

B.1.2.2 Accuracy for Radiochemical Analysis . . . . . . . . . . . . . B-11

B.1.2.3 Accuracy Summary . . . . . . . . . . . . . . . . B-14

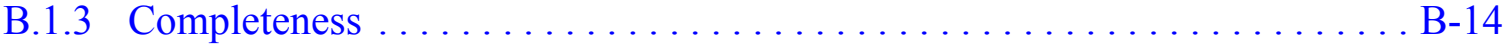

B.1.3.1 Completeness Summary . . . . . . . . . . . . . . . . B-16

B.1.4 Rejected Data . . . . . . . . . . . . . . . . . . . . . . . . . . . . . . . . . . . .

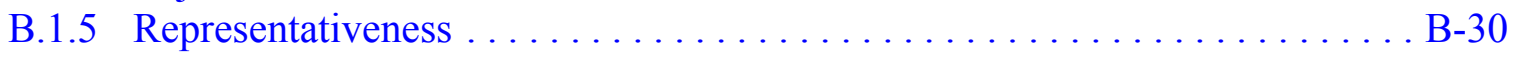

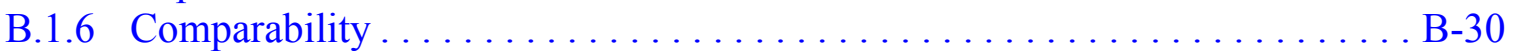

B.1.7 Reconciliation of Conceptual Site Models to the Data. . . . . . . . . . . . . . . B-30

B.1.7.1 Conceptual Site Models. . . . . . . . . . . . . . . . . . . B-30

B.1.7.1.1 Leakage or Spilling from ASTs and

Associated Processes Conceptual Site Model ... . . . . B-31

B.1.7.1.2 Injection Wells and Associated Soils Conceptual

Site Model . . . . . . . . . . . . . . . . . . B-31

B.1.7.2 Contaminant Nature and Extent. . . . . . . . . . . . . B-32

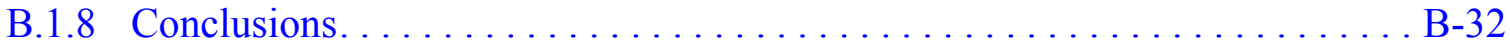

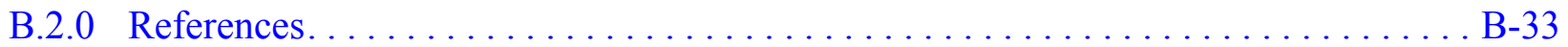

\section{Appendix C - Cost Estimates for CAU 322}

Appendix D - Sample Location Coordinates for CAU 322: Release Sites and Injection Wells Nevada Test Site, Nevada

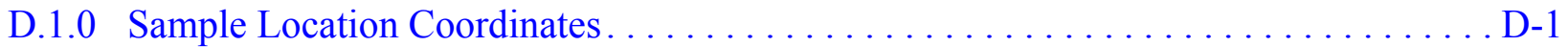

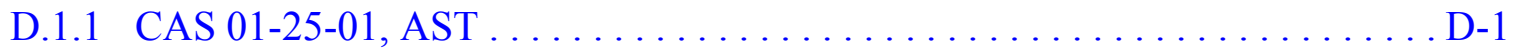

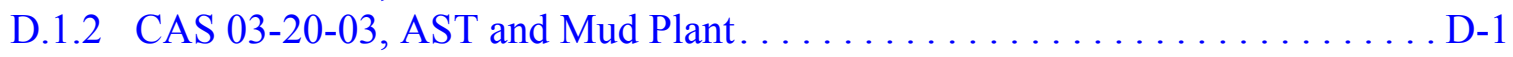

D.1.3 CAS $03-20-05$, Injection Wells ........................

\section{Appendix E - Evaluation of Risk}

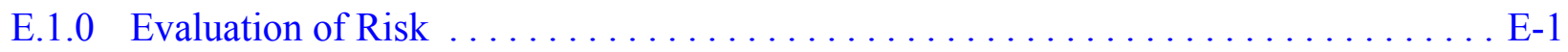




\section{Table of Contents (Continued)}

E.1.1 Human Health Screening $\ldots \ldots \ldots \ldots \ldots \ldots \ldots \ldots \ldots \ldots \ldots \ldots \ldots \ldots \ldots \ldots \ldots$

E.1.2 Risk Evaluation. . . . . . . . . . . . . . . . . . . . . . . . E-2

E.1.3 Uncertainty Analysis. . . . . . . . . . . . . . . . . . . . . E-4

E.1.4 Interpretation. . . . . . . . . . .

E.2.0 References................................... E-6

Appendix F - Project Organization for CAU 322

F.1.0 Project Organization $\ldots \ldots \ldots \ldots \ldots \ldots \ldots \ldots \ldots \ldots \ldots \ldots \ldots \ldots \ldots \ldots \ldots \ldots \ldots \ldots$ Appendix G - Nevada Division of Environmental Protection Comments 


\section{List of Figures}

Number

Title

Page

1-1 Nevada Test Site Location Map . . . . . . . . . . . . . . . . . 2

1-2 CAU 322 CAS Location Map $\ldots \ldots \ldots \ldots \ldots \ldots \ldots \ldots \ldots \ldots \ldots \ldots \ldots$

A.3-1 Sample Location Map, CAS 01-25-01, AST Berm . . . . . . . . . . . . . . . . A-14

A.3-2 Radiological Survey Map for CAS 01-25-01, AST Berm . . . . . . . . . . A-16

A.3-3 Vertical Profile of TPH-DRO Concentrations for CAS 01-25-01, AST Berm .... A-21

A.3-4 TPH-DRO Data Regression Plot for CAS 01-25-01, AST Berm . . . . . . . . A-23

A.4-1 Sample Location Map for CAS 03-25-03, AST Release

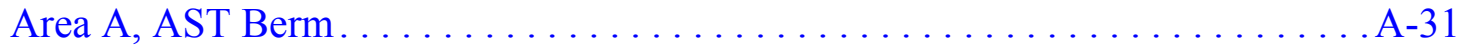

A.4-2 Sample Location Map for CAS 03-25-03, AST Release

Area B, Mud Plant . . . . . . . . . . . . . . . . . . . . . . . A-32

A.4-3 Radiological Survey Map for CAS 03-25-03, AST Release . . . . . . . . . . . . A-34

A.4-4 Plan View Plot of TPH-DRO Hits above PALs at

CAS 03-25-03, AST Release, Site B (East Side of Mud Plant). . . . . . . . . . . . A-47

A.4-5 Vertical Cross Section of TPH-DRO Concentrations at

CAS 03-25-03, AST Release, Site B (East Side of Mud Plant) . . . . . . . . . . . . A-48

A.5-1 Soil Sample Location Map for CAS 03-20-05, Injection Wells . . . . . . . . . . A-60

A.5-2 Sample Locations for Tanks and Sumps at CAS 03-20-05, Injection Wells ..... . A-61

A.5-3 Radiological Survey Map for CAS 03-20-05, Injection Wells . . . . . . . . . . . . A-62

A.5-4 Profile of Injection Well Sump and Vault with Analytical Results . . . . . . . . . A-75 


\section{List of Tables}

Number

Title

Page

1-1 Corrective Action Unit 322 Corrective Action Sites . . . . . . . . . . . . . . . 1

3-1 Corrective Action Alternatives Evaluated for CAU $322 \ldots \ldots \ldots \ldots \ldots$

3-2 Detailed Evaluation of Alternatives for Corrective Action Unit 322 . . . . . . 35

3-3 Comparative Evaluation of Alternatives for Corrective Action Unit $322 \ldots \ldots$. . . 38

A.2-1 Corrective Action Investigation Activities Conducted at Each

Corrective Action Site to Meet Corrective Action Investigation

Plan Requirements

A.2-2 Laboratory Analytical Parameters and Methods,

CAU 322 Investigation Samples

A.3-1 Samples Collected at CAS 01-25-01, AST . . . . . . . . . . . A-13

A.3-2 Soil Sample Results for Total VOCs Detected Above Minimum Reporting Limits at CAS $01-25-01$ AST . . . . . . . . . . . . .

A.3-3 Soil Sample Results for Metals Detected Above Minimum Reporting Limits at CAS $01-25-01$, AST . . . . . . . . . . . . . . . . . . A-19

A.3-4 Soil Sample Results for TPH (DRO and GRO) Detected Above Minimum Reporting Limits at CAS 01-25-01, AST . . . . . . . . . . . . A-20

A.3-5 Soil Sample Results for Gamma-Emitting Radionuclides

Detected Above Minimum Detectable Concentrations at CAS 01-25-01, AST.

A.4-1 Samples Collected at CAS 03-25-03, AST and Mud Plant

A.4-2 Samples Collected During the CAU 34 CAI at CAS 03-25-03, Area B (East of Mud Plant)

A.4-3 Soil Sample Results for Total VOCs Detected Above Minimum Reporting Limits at CAS 03-25-03, Mud Plant AST

Diesel Release A-36 


\section{List of Tables (Continued)}

Number

Title

Page

A.4-4 Soil Sample Result for Total SVOCs Detected Above Minimum

Reporting Limits at CAS 03-25-03, Mud Plant AST Diesel Release . . . . . . . A-36

A.4-5 Soil Sample Results for PCBs Detected Above Minimum

Reporting Limits at CAS 03-25-03, Mud Plant AST Diesel Release . . . . . . . A-37

A.4-6 Soil Sample Results for Metals Detected Above Minimum

Reporting Limits at CAS 03-25-03, Mud Plant AST Diesel Release . . . . . . . A-38

A.4-7 Soil Sample Results for TPH (DRO and GRO) Detected Above

Minimum Reporting Limits at CAS 03-25-03, Mud Plant AST

Diesel Release

A.4-8 Vertical Bounding of TPH-DRO at Area B . . . . . . . . . . . A A-45

A.4-9 Soil Sample Results for Gamma-Emitting Radionuclides Detected

Above Minimum Reporting Limits at CAS 03-25-03, Mud Plant AST

Diesel Release . . . . . . . . . . . . . . . . . . . . . . . . . A A-49

A.4-10 Soil Sample Results for Isotopes Detected Above Minimum

Reporting Limits at CAS 03-25-03, Mud Plant AST Diesel Release . . . . . . . A-51

A.5-1 Samples Collected at CAS 03-20-05, Injection Well. . . . . . . . . . . A-55

A.5-2 Soil Sample Results for Total VOCs Detected

Above Minimum Reporting Limits at CAS 03-20-05, Injection Well . . . . . . A-65

A.5-3 Soil Sample Results for Total SVOCs Detected

Above Minimum Reporting Limits at CAS 03-20-05, Injection Well . . . . . . A-66

A.5-4 Soil Sample Results for Metals Detected Above Minimum Reporting Limits at

CAS 03-20-05, Injection Well . . . . . . . . . . . . . . . . . . . A-67

A.5-5 Soil Sample Results for PCBs Detected Above

Minimum Reporting Limits at CAS 03-20-05, Injection Well . . . . . . . . . . A-72

A.5-6 Soil Sample Results for TPH-DRO Detected Above

Minimum Reporting Limits at CAS 03-20-05, Injection Well . . . . . . . . . . . A-73 


\section{List of Tables (Continued)}

Number

Title

Page

A.5-7 Soil Sample Results for Gamma-Emitting Radionuclides

Detected Above Minimum Reporting Limits at CAS 03-20-05, Injection Well.

A.5-8 Soil Sample Results for Isotopes Detected Above Minimum Reporting Limits at CAS $03-20-05$, Injection Well . . . . . . . . . . . . . . A-83

A.6-1 Liquid and Oil Samples Collected at CAS 03-20-05, Injection Well . . . . . . A-94

A.6-2 Soil Samples for TCLP Metals Detected Above Minimum Reporting Limits at CAS 03-20-05, Injection Well.

B.1-1 Chemical Precision Measurements for CAU $322 \ldots \ldots \ldots \ldots \ldots \ldots \ldots \ldots$. . . . . . . .

B.1-2 Radiological Precision Measurements for CAU $322 \ldots \ldots \ldots \ldots \ldots \ldots$. . . . . . . .

B.1-3 Chemical Accuracy Measurements for CAU $322 \ldots \ldots \ldots \ldots \ldots \ldots$. . . . . . .

B.1-4 Radiological Accuracy Measurements for CAU 322. . . . . . . . . . . . B-12

B.1-5 Chemical Completeness Measurements for CAU $322 \ldots \ldots \ldots \ldots \ldots \ldots \ldots$. . . . 14

B.1-6 Radiological Completeness Measurements for CAU $322 \ldots \ldots \ldots \ldots \ldots$. . . B-15

B.1-7 CAU 322 Rejected Data at CAS 01-25-01, AST . . . . . . . . . . . B-17

B.1-8 CAU 322 Rejected Data at CAS 03-25-03, Mud Plant AST Diesel Release. .. . B-18

B.1-9 CAU 322 Rejected Data at CAS 03-20-05, Injection Well . . . . . . . . . B-21

D.1-1 Sample Location GPS Coordinates for CAS $01-25-01 \ldots \ldots \ldots \ldots \ldots \ldots$. . . .

D.1-2 Sample Location GPS Coordinates for CAS $03-25-03 \ldots \ldots \ldots \ldots \ldots \ldots$. . . .

D.1-3 Sample Location GPS Coordinates for CAS 03-20-05 . . . . . . . . . . D-3 


\section{List of Acronyms and Abbreviations}

$\mathrm{AL}$

Am

$\mathrm{AR} / \mathrm{COC}$

AST

bgs

BOP

CADD

CAI

CAIP

CAS

CAU

CFR

CLP

$\mathrm{COC}$

COPC

Cs

CSM

DOE

DQI

DQO

DRO

EPA

FADL

FAL

FID

FFACO
Action level

Americium

Analysis requests/chain-of-custody

Aboveground storage tank

Below ground surface

Blowout Preventer

Corrective Action Decision Document

Corrective Action Investigation

Corrective Action Investigation Plan

Corrective Action Site

Corrective Action Unit

Code of Federal Regulations

Contract Laboratory Program

Contaminants of concern

Contaminants of potential concern

Cesium

Conceptual site models

U.S. Department of Energy

Data quality indicators

Data quality objectives

Diesel-range organics

U.S. Environmental Protection Agency

Field activity daily log

Final action level

Flame ionization detector

Federal Facility Agreement and Consent Order 


\section{List of Acronyms and Abbreviations (Continued)}

\begin{tabular}{|c|c|}
\hline FSL & Field-screening levels \\
\hline FSR & Field-screening results \\
\hline $\mathrm{ft}$ & Foot (feet) \\
\hline $\mathrm{ft}^{2}$ & Square feet \\
\hline $\mathrm{ft}^{3}$ & Cubic feet \\
\hline GPS & Global positioning system \\
\hline GRO & Gasoline-range organics \\
\hline HWAA & Hazardous Waste Accumulation Area \\
\hline IDW & Investigation-derived waste \\
\hline ID & Identification number \\
\hline in. & Inch \\
\hline LCS & Laboratory control samples \\
\hline LCSD & Laboratory control sample duplicates \\
\hline LD & Laboratory duplicate \\
\hline LLNL & Lawrence Livermore National Laboratory \\
\hline LLW & Low-level radioactive waste \\
\hline MADEP & Massachusetts Department of Environmental Protection \\
\hline MDC & Minimum detectable concentration \\
\hline $\mathrm{mg} / \mathrm{kg}$ & Milligrams per kilogram \\
\hline $\mathrm{mg} / \mathrm{L}$ & Milligrams per liter \\
\hline $\mathrm{mi}$ & Mile \\
\hline MRL & Minimum reporting limit \\
\hline $\mathrm{mrem} / \mathrm{yr}$ & Millirem per year \\
\hline MS & Matrix spike \\
\hline MSD & Matrix spike duplicate \\
\hline $\mathrm{NAC}$ & Nevada Administrative Code \\
\hline NCRP & National Council on Radiation Protection and Measuren \\
\hline
\end{tabular}




\section{List of Acronyms and Abbreviations (Continued)}

\begin{tabular}{|c|c|}
\hline ND & Normalized difference \\
\hline NDEP & Nevada Division of Environmental Protection \\
\hline NIST & National Institute for Standards and Technology \\
\hline NNSA/NSO & $\begin{array}{l}\text { U.S. Department of Energy, National Nuclear Security Administration } \\
\text { Nevada Site Office }\end{array}$ \\
\hline NTS & Nevada Test Site \\
\hline NTSWAC & Nevada Test Site Waste Acceptance Criteria \\
\hline PAL & Preliminary action level \\
\hline PB & Preparation blanks \\
\hline PCB & Polychlorinated biphenyls \\
\hline POC & Performance objective criteria \\
\hline PPE & Personal protective equipment \\
\hline ppm & Parts per million \\
\hline PRG & Preliminary Remediation Goal \\
\hline $\mathrm{Pu}$ & Plutonium \\
\hline QA & Quality assurance \\
\hline QAPP & Quality Assurance Project Plan \\
\hline QC & Quality control \\
\hline RAGS & Risk Assessment Guidance \\
\hline RCRA & Resource Conservation and Recovery Act \\
\hline ROTC & Record of Technical Change \\
\hline RPD & Relative percent difference \\
\hline RWMS & Radioactive Waste Management Site \\
\hline SCL & Sample collection log \\
\hline SDG & Sample delivery group \\
\hline SVOC & Semivolatile organic compounds \\
\hline TCLP & Toxicity characteristic leaching procedure \\
\hline
\end{tabular}




\section{List of Acronyms and Abbreviations (Continued)}

TPH Total petroleum hydrocarbons

VOC Volatile organic compounds

VSP Visual Sample Plan

$\mathrm{yd}^{3} \quad$ Cubic yards

$\mu \mathrm{g} \quad$ Microgram

$\%$ Percent recovery 


\section{Executive Summary}

This Corrective Action Decision Document has been prepared for Corrective Action Unit (CAU) 322, Areas 1 and 3 Release Sites and Injection Wells, Nevada Test Site, Nevada, in accordance with the Federal Facility Agreement and Consent Order (1996). Corrective Action Unit 322 is comprised of the following corrective action sites (CASs):

- 01-25-01 - AST Release Site

- 03-25-03 - Mud Plant and AST Diesel Release*

- 03-20-05 - Injection Wells and BOP Shop

*Note: CAS 03-25-03 is presented as Areas A and B based on technical evaluations.

The purpose of this Corrective Action Decision Document is to identify and provide the rationale for the recommendation of a corrective action alternative for each CAS within CAU 322. Corrective action investigation activities were performed from April 2004 through September 2004, as set forth in the Corrective Action Investigation Plan. The purposes of the activities as defined during the data quality objectives process were:

- Determine if contaminants of concern (COCs) are present

- If COCs are present, determine their nature and extent

- Provide sufficient information and data to recommend appropriate corrective actions for the CASs.

Analytes detected during the corrective action investigation were evaluated against appropriate preliminary action levels to identify contaminants of concern for each corrective action site. Radiological field measurements were compared to unrestricted release criteria. Assessment of the data generated from investigation activities revealed the following:

- CAS 01-25-01 contains an AST berm contaminated with total petroleum hydrocarbons (TPH) diesel-range organics (DRO).

- CAS 03-25-03 includes two distinct areas: Area A where no contamination remains from a potential spill associated with an AST, and Area B where TPH-DRO contamination associated with various activities at the mud plant was identified. The Area B contamination was found at various locations and depths. 
- CAS 03-25-03 Area B contains TPH-DRO contamination at various locations and depths in the area associated with the Mud Plant.

- CAS 03-20-05 contains TPH-DRO, metals, and radiological contamination within the injection well casing soil and TPH-DRO contamination at the depth coincidental with the bottom of the injection well sump.

Based on the evaluation of analytical data from the corrective action investigation, review of future and current operations in Areas 1 and 3 of the Nevada Test Site, and the detailed and comparative analysis of the potential corrective action alternatives, the following corrective actions are recommended for the Corrective Action Unit 322 CASs.

Closure in Place with Administrative Controls is the preferred corrective action for the following CASs:

- CAS 01-25-01, removal of TPH-DRO contamination would pose a significant safety hazard due to the site location.

- CAS 03-25-03 No contamination remains at Area A (AST Berm); and thus, no further action is the preferred alternative at this part of the CAS. However at Area B, TPH-DRO contamination is varied in concentration and location and the footprint of the CAS is large, removal of contaminated "pockets" would be laborious and cost prohibitive.

The plutonium-239 surface contamination identified at CAS 03-25-03 Area B has been removed and drummed as a best management practice.

- CAS 03-20-05, TPH-DRO, metals, and radiological contamination are present in the injection well casing soils. Recommend corrective action includes removal of the liquid in the injection well sump (approximately $3 \mathrm{feet}(\mathrm{ft}$ ) of liquid at $60 \mathrm{ft}$ below ground surface), grouting the sump, and the area within the injection well casing.

The plutonium-239 surface contamination identified at CAS 03-20-05 has been removed and drummed as a best management practice and will be disposed of as low-level radioactive waste. It is recommended that the liquids be removed from the holding tank wells and the sumps of the two outer holding tanks within the BOP Shop, and the sumps be grouted, and the holding tanks filled in to the BOP Shop floor surface.

The preferred corrective action alternatives were evaluated on technical merit focusing on performance, reliability, feasibility, and safety. The alternatives were judged to meet all requirements 
CAU 322 CADD

Executive Summary

Revision: 0

Date: December 2004

Page ES-3 of ES-3

for the technical components evaluated. The alternatives meet all applicable state and federal regulations for closure of the site and will reduce potential future exposure pathways to the contaminated media at Corrective Action Unit 322. 


\subsection{Introduction}

This Corrective Action Decision Document (CADD) has been prepared for Corrective Action Unit (CAU) 322: Areas 1 and 3 Release Sites and Injection Wells, Nevada Test Site (NTS), Nevada, in accordance with the Federal Facility Agreement and Consent Order (FFACO) that was agreed to by the State of Nevada, U.S. Department of Energy (DOE), and the U.S. Department of Defense (FFACO, 1996).

This CADD provides or references the specific information necessary to recommend corrective actions for the three CAU 322 corrective action sites (CASs) indicated in Table 1-1

Table 1-1

Corrective Action Unit 322 Corrective Action Sites

\begin{tabular}{|c|c|c|c|}
\hline $\begin{array}{l}\text { Nevada Test } \\
\text { Site Area }\end{array}$ & Corrective Action Site & CAS Description ${ }^{a}$ & $\begin{array}{l}\text { Facility, Program, or } \\
\text { Location Association }^{b}\end{array}$ \\
\hline Area 1 & $01-25-01$ & AST Release & Area 1 Batch Plant \\
\hline \multirow[b]{2}{*}{ Area 3} & $03-25-03$ & Mud Plant AST Diesel Release & Former Area 3 Mud Plant \\
\hline & $03-20-05$ & Injection Wells & $\begin{array}{l}\text { Blowout Preventer Shop and } \\
\text { Injection Wells }\end{array}$ \\
\hline
\end{tabular}

${ }^{\mathrm{a} C A S}$ description from the FFACO (1996)

${ }^{\mathrm{b}}$ General location from the FFACO (1996)

The NTS is located approximately 65 miles (mi) northwest of Las Vegas in Nye County, Nevada (Figure 1-1). The CASs within CAU 322 are located in Areas 1 and 3 of the NTS, as shown on Figure 1-2.

\subsection{Purpose}

This CADD develops and evaluates potential corrective action alternatives for each CAS within CAU 322 and provides a rationale for the selection of a recommended corrective action alternative for each CAS. The need for evaluation of corrective action alternatives is based on process knowledge and the results of investigative activities conducted in accordance with the CAU 322 Corrective Action Investigation Plan (CAIP) (NNSA/NSO, 2003). 


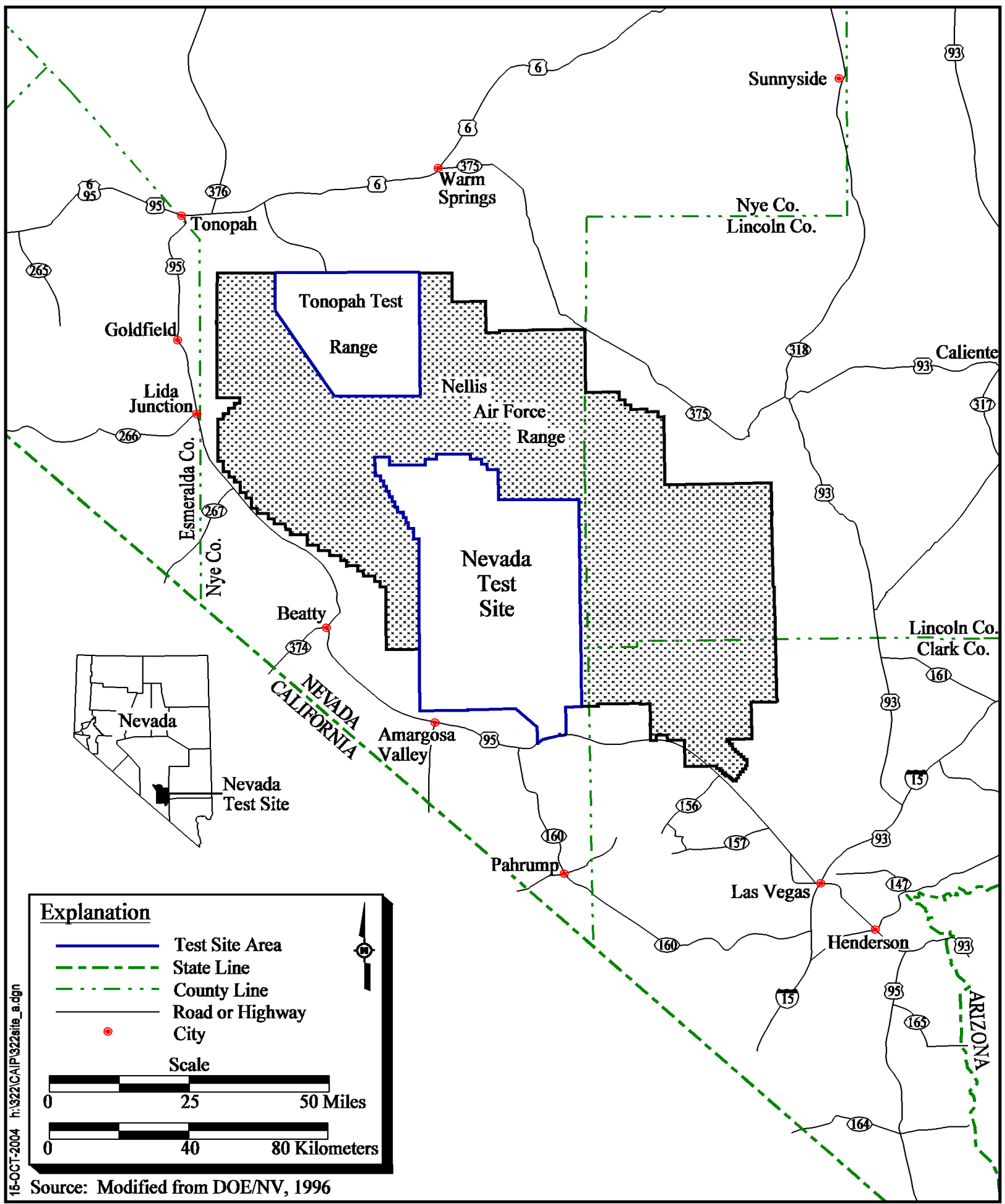

Figure 1-1

Nevada Test Site Location Map 


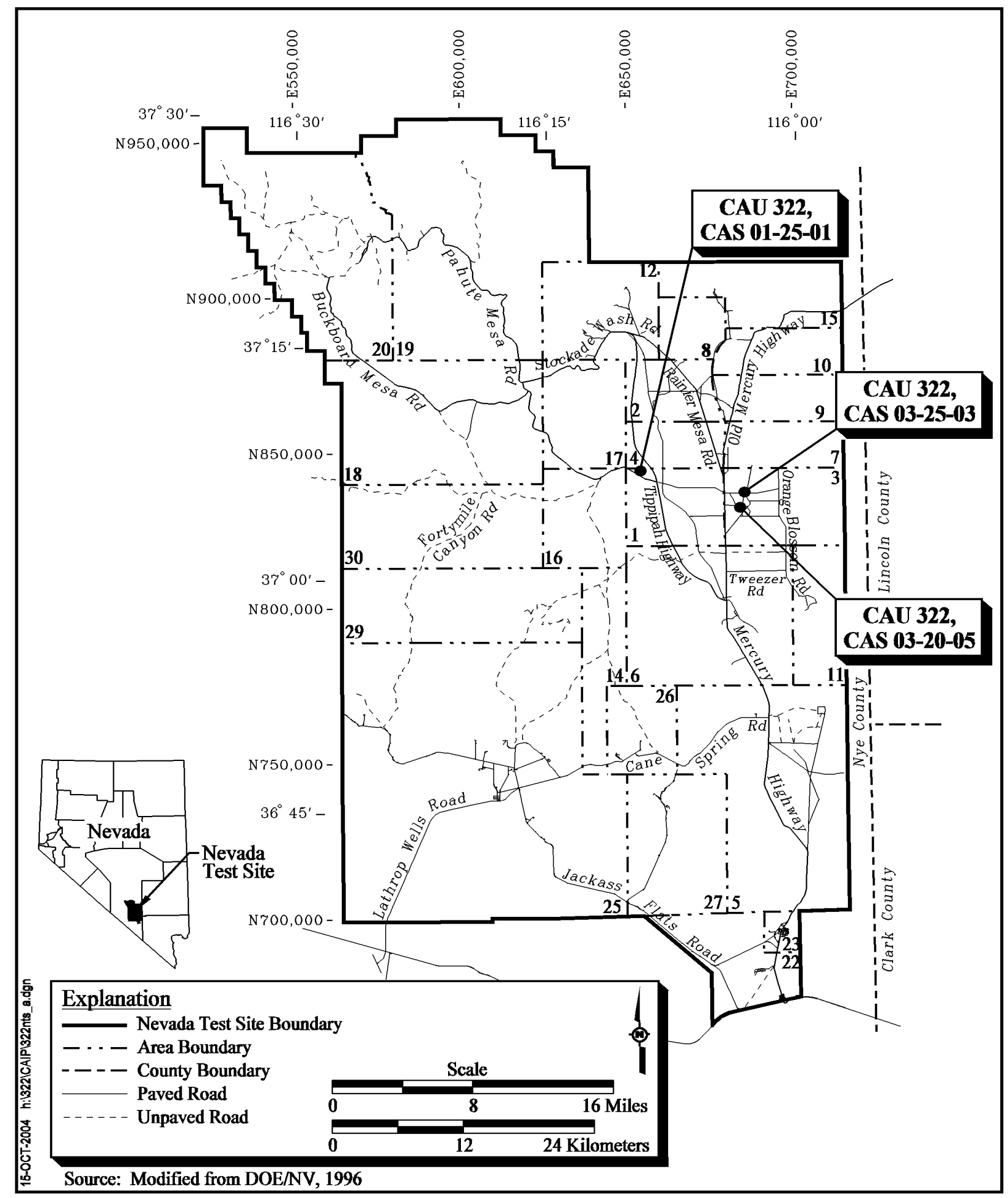

Figure 1-2

CAU 322 CAS Location Map 
This CAU was investigated due to the existing process knowledge which indicated that the CASs within this CAU may have been used to store or dispose of material considered to be hazardous or radioactive waste by current standards. All CASs within CAU 322 were found to be as described in the CAIP and are discussed below:

Corrective Action Site 01-25-01 is located in the northern portion of the Shaker Plant facility in Area 1 of the NTS. The CAS consists of a potential release from a 10,000 gallon diesel fuel tank housed in an earthen and gravel berm that was once used to fuel the batch plant operation.

Corrective Action Site 03-25-03 is located at the Mud Plant in Area 3 of the NTS, in an area referred to as the Area 3 Man Camp. The CAS consists of two distinct areas (Area A and Area B). Area A, on the western end of the CAS, consists of a potential release from a diesel fuel tank once housed in a J-shaped berm. Area B is located on the eastern end of the CAS and on the east side of the Mud Plant. Area B was theorized to consist of multiple potential discrete fuel releases or was contaminated by subsurface migration of contaminants from Area A.

Corrective Action Site 03-20-05 is located in Area 3 of the NTS at the Blowout Preventer (BOP) Shop in an area referred to as the Area 3 Man Camp. This CAS consists of several potential releases, including contaminants from one or more of the three in-ground holding tanks and sumps (in the two outermost tanks only) within the BOP Shop, overflow of one or more of the holding tanks onto the floor of the BOP Shop, leakage from the underground transfer line from the holding tanks to the injection well, dispersion from the injection well sump into the surrounding soils, and percolation from the injection well casing soils into underlying soils. The injection well is located approximately 65 feet (ft) to the east of the southern end of the BOP Shop. The well is fed by an underground pipe from the BOP Shop, and is approximately $65 \mathrm{ft}$ in depth. The sump in the injection well is approximately 10 inches (in.) in diameter and slotted beginning at approximately $28 \mathrm{ft}$ below ground surface (bgs). Approximately 2 to $3 \mathrm{ft}$ of liquid is currently at the bottom of the sump.

Additional information regarding the history of each site, planning, and the scope of the investigation is presented in the CAU 322 CAIP (NNSA/NSO, 2003). 


\subsection{Scope}

The scope of the activities used to identify, evaluate, and recommend corrective action alternatives for each CAS within CAU 322 included the following:

- Evaluation of current site conditions, including the concentration and extent of contaminants of concern (COCs)

- Development of corrective action objectives commensurate with the complexity of each CAS

- Identification of corrective action alternative screening criteria

- Performance of detailed and comparative evaluations of corrective action alternatives in relation to corrective action objectives and screening criteria

\subsection{Corrective Action Decision Document Contents}

This CADD is divided into the following sections and appendices:

Section 1.0 - Introduction: Summarizes the purpose, scope, and contents of this CADD.

Section 2.0 - Corrective Action Investigation Summary: Summarizes the investigation field activities, the results of the investigation, and the need for corrective action at this CAU.

Section 3.0 - Evaluation of Alternatives: Describes, identifies, and evaluates the steps taken to determine a preferred corrective action alternative for each CAS.

Section 4.0 - Recommended Alternatives: Presents the preferred corrective action alternative for each CAS and the rationale for selecting that alternative based on the corrective action objectives and screening criteria.

Section 5.0 - References: Provides a list of all referenced documents used in the preparation of this CADD.

Appendix A: Corrective Action Investigation Results for CAU 322: Provides a description of the project objectives, field investigation and sampling activities, investigation results, waste management, and quality assurance practices. Section A.3.0 through Section A.5.0 provide 
CAS-specific information regarding field activities, sampling methods, and laboratory analytical results from the investigation sampling.

Appendix B: Data Assessment of Sample Results for CAU 322: Provides an assessment of data obtained during the CAU 322 investigation. The appendix also summarizes and compares the investigation results to the requirements set forth during the data quality objective (DQO) process.

Appendix C: Cost Estimates for CAU 322: Presents cost estimates for the construction, operation, and maintenance of each corrective action alternative evaluated for each CAS.

Appendix D: Sample Location Coordinates for CAU 322: Provides the global positioning system (GPS) coordinates for investigation sample locations and points of interest at each CAS.

Appendix E: Risk Evaluation for CAU 322: Provides a discussion of the risks associated with leaving contamination above action levels (ALs) in place.

Appendix F: Project Organization: Identifies the Project Manager and other appropriate personnel involved with the CAU 322 characterization and closure activities.

Appendix G: Response to Nevada Division of Environmental Protection comments.

To ensure all project objectives, health and safety requirements, and quality control procedures were adhered to, all investigation activities were performed in accordance with the following documents:

- Corrective Action Investigation Plan for CAU 322: Area 1 and 3 Release Sites and Injection Wells (NNSA/NSO, 2003).

- Record of Technical Change (ROTC) No. 1 to the CAIP (NNSA/NSO, 2003), was prepared in April 2004 and has been approved by the Nevada Division of Environmental Protection (NDEP). This ROTC documents changes to the radiological PALs and adds appropriate references. The ROTC also changes a requirement for laboratory analysis of all samples obtained at the Mud Plant aboveground storage tank (AST) release site to indicate that all samples collected will be field screened for total petroleum hydrocarbon (TPH) diesel-range organics (DRO), and appropriate samples will be forwarded for laboratory analysis. Finally, references to quick turn-around analyses for samples taken at the Mud Plant AST release site were removed.

- Industrial Sites Quality Assurance Project Plan (QAPP) (NNSA/NV, 2002) 
CAU 322 CADD

Section: 1.0

Revision: 0

Date: December 2004

Page 7 of 43

- Federal Facility Agreement and Consent Order (1996)

- Project Management Plan (DOE/NV, 1994) 


\subsection{Corrective Action Investigation Summary}

The following sections summarize the CAU 322 investigation activities, investigation results, and identify the need for corrective action at each CAS. Detailed investigation activities and results for CAU 322 are presented in Appendix A.

\section{$2.1 \quad$ Investigation Activities}

Corrective action investigation activities were performed from April 12 through September 12, 2004, as set forth in the CAU 322 CAIP (NNSA/NSO, 2003). Investigation activities were conducted to:

- Determine if contaminants of potential concern (COPCs) are present within environmental media at the CAS

- Determine whether the COPCs, if present, exceed ALs, thereby becoming COCs

- Determine the lateral and vertical extent of identified COCs

- Collect sufficient data to address the decision statements as outlined in the CAIP

- Ensure adequate data have been collected to evaluate and recommend a corrective action alternative

- Collect sufficient data to make waste disposal decisions

Sufficient information was obtained to define the nature and extent of contamination associated with each CAS, and develop and evaluate corrective action alternatives for each CAS located within CAU 322.

General investigation activities included:

- Collecting environmental soil samples for laboratory analyses to determine the nature of COCs.

- Identifying COCs at CASs and collected additional environmental samples for laboratory analyses to define the vertical and lateral extent of contamination.

- Collecting GPS coordinates at sample locations. 
- Collecting and analyzing samples to support waste characterization.

- Field-screening soil samples at each CAS for alpha and beta/gamma radiation, volatile organic compounds (VOCs), and TPH at all CASs.

- Collecting quality control (QC) samples for laboratory analyses to ensure that the data generated from the analysis of investigation samples meet the requirements of the data quality indicators (DQIs).

A judgemental (nonprobabilistic) sampling scheme was implemented to select sample locations and evaluate analytical results. Judgemental sampling allows the methodological selection of sample locations that target the populations of interest (defined in the DQOs) rather than the non-selective random locations. Random sample locations are used to generate average contaminant concentrations that estimate the true average (characteristic) contaminant concentration of the site to some specified degree of confidence.

Since individual sample results, rather than an average concentration, will be used to compare to action levels, statistical methods used to generate site characteristics (averages) will not be necessary. Section 0.4.4 of the U.S. Environmental Protection Agency (EPA) Data Quality Objectives for Hazardous Waste Site Investigations (EPA, 2000) guidance states that the use of statistical methods may not be warranted by program guidelines of site-specific sampling objectives. The need for statistical methods is dependent upon the decisions being made. Section 7.1 of the EPA QA/G-4HW guidance states that a nonprobabilistic (judgemental) sampling design is developed when there is sufficient information on the contamination sources and history to develop a valid conceptual site model and to select specific sampling locations. This design was used to confirm the existence of contamination at specific locations and provide information (such as extent of contamination) about specific areas of the site.

Confidence in judgemental sampling results will be established qualitatively through the validation of the conceptual site model (CSM) developed and concurred to by stakeholder participants (U.S. Department of Energy, National Nuclear Security Administration Nevada Site Office [NNSA/NSO] and NDEP) during the DQO process based on investigation results and by evaluating the quality of the data based on DQI parameters. 
Two CSMs were developed for CAU 322 to represent the release mechanisms and potential migration pathways for each CAS. These are provided in Appendix A of the CAU 322 CAIP. The system configurations, migration pathways, and release mechanisms identified during the field investigation were consistent with the CSMs provided in the CAIP except where otherwise specified in this CADD. The CSMs included soil potentially impacted by surface and/or subsurface disposal and or release of contaminants. The release mechanisms include intentional and accidental releases. The models assumed that any contamination would be concentrated in the soil immediately beneath and adjacent to the location of the release. The extent of underlying soil impacted was expected to be variable and dependent upon the volume of material released, physical and chemical properties of the surrounding media, geological conditions, and physical and chemical properties of the impacted media as well as the COPCs.

The following sections summarize the specific investigation activities at each CAS and discusses the validity of the CSMs.

\subsubsection{CAS 01-25-01, AST Release}

Investigation activities conducted at CAS 01-25-01 included walk-over radiological survey, biased surface and shallow subsurface soil sampling, field screening for TPH-DRO and VOCs, and collection and analysis of material suspected of containing TPH-DRO.

Investigation results indicate TPH-DRO contamination was more extensive than indicated in the Preliminary Assessments investigation; however, it was not necessary to modify the CSM for this CAS. The entire soil surface of the berm floor contained TPH-DRO at concentrations exceeding the preliminary action level (PAL). Additional samples were obtained outside the berm to determine lateral extent of contamination and a backhoe was used to obtain samples to demonstrate vertical depth within the berm.

Samples were shipped to an off-site laboratory for the analyses listed in Table A.3-1. Investigation activities associated with CAS 01-25-01 are further detailed in Section A.3.0. 


\subsubsection{CAS 03-25-03, Mud Plant and AST Diesel Release}

Investigation activities at CAS 03-25-03 involved characterization sampling of the CAS components including soils at the site of a J-shaped berm that once contained a diesel fuel AST (Area A). Additional activities include the sampling of soils along the east side of the Mud Plant (Area B) for TPH-DRO contamination based on sample results obtained from CAU 34.

\subsubsection{CAS 03-25-03, Area A, AST Release}

Activities at this area of interest included a radiological walk-over survey, surface and shallow subsurface soil sampling using hand augurs and a backhoe, drilling with a rotosonic drill rig, and field screening for TPH-DRO and VOCs.

Samples were shipped to an off-site laboratory for the analyses listed in Table A.4-1. Investigation activities associated with CAS 03-25-03 are further detailed in Section A.4.0.

\subsubsection{CAS 03-25-03, Area B, Mud Plant}

Activities at this area of interest included a radiological walk-over survey, surface and shallow subsurface soil sampling using hand augurs and a backhoe, drilling with a rotosonic drill rig, and field screening for TPH-DRO and VOCs. Samples were shipped to an off-site laboratory for the analyses outlined in Table A.4-1. Investigation activities associated with CAS 03-25-03 are further detailed in Section A.4.0.

\subsubsection{CAS 03-20-05, Injection Wells}

Investigation activities at CAS 03-20-05 were comprised of a radiological walk-over survey, characterization sampling of three in-ground holding tanks and their sumps (present in only two of the tanks) within the BOP Shop, sampling of soils adjacent to the holding tanks outside the BOP Shop, sampling of surface and shallow subsurface soils outside the BOP Shop, sampling of soils adjacent to the injection well, and soil sampling along the underground piping leading from the BOP Shop holding tanks to the injection well. Liquid samples were collected from the sump of the injection well (at a depth of approximately $62 \mathrm{ft} \mathrm{bgs)}$ ), as well as soil samples from within the injection well vault surrounding the injection well sump. Radiation surveys were also conducted of the BOP 
Shop floor, the lids covering the in-ground holding tanks, the inner walls of the in-ground holding tanks, the lid covering the injection well, the inner walls of the casing surrounding the injection well, and the injection well sump to its depth of approximately $62 \mathrm{ft}$ bgs.

Samples were shipped to an off-site laboratory for the analyses listed in Table A.5-1. Investigation activities associated with CAS 03-20-05 are further detailed in Section A.5.0.

For each CAS, the conceptual site model is considered valid based upon the analytical results provided by the laboratory.

\subsection{Results}

A summary of characterization data from the CAU $322 \mathrm{CAI}$ is provided in Section 2.2.1. This information illustrates the degree of characterization accomplished through the field effort and identifies those COPCs that exceed PALs and were subsequently classified as COCs. Section 2.2.2 summarizes the assessment made in Appendix B which demonstrates the correlation between the investigation results and the DQOs.

\subsubsection{Summary of Characterization Data}

Chemical and radiological results for investigation samples collected at each of the CASs are summarized in Section 2.2.1.1 through Section 2.2.1.3. The PALs for the CAU 322 investigation were determined during the DQO process and are discussed in Section 3.3 of the CAIP (NNSA/NSO, 2003). Record of Technical Change No. 1 to the CAS was completed to document subsequent agreements between NDEP and NNSA/NSO regarding the reference source and values for dose-based radiological PALs and the application of those PALs to the findings of the CAU 322 CAI.

Details about the methods used during this investigation and a comparison of environmental sample results to the ALs defined in Section 3.1 are presented in Appendix A. Sample locations that support the presence and/or extent of contamination at each CAS are shown in the Appendix A figures. Based on the results presented in Appendix A, the nature and extent of COCs at CAU 322 have been adequately identified to develop and evaluate corrective action alternatives. 
The following sections summarize CAI analytical results on a CAS-specific basis.

\subsubsection{CAS 01-25-01, AST Release}

The TPH-DRO was identified as a COC based on analytical results of soil samples collected within the AST berm. Additional sampling was performed both within and outside the bermed area to delineate the lateral and vertical extent of the TPH-DRO contamination. Results of the analyses provide the following information for CAS 01-25-01.

Samples collected at locations A01 and A02 confirm the presence of TPH-DRO above the PAL at all depths. Samples 322A004 and 322A009 through 322A011 at sample location A02 show a decrease in TPH-DRO concentration with depth and distance from the source, as theorized in the CSM. Samples collected at location A02 were unable to define the vertical depth to TPH-DRO concentrations below the PAL due to safety considerations. The deepest sample (collected at $10 \mathrm{ft}$ beneath the berm floor in the native soil at sample site A02) indicated the concentration of TPH-DRO was 140 parts per million (ppm). Contamination associated with the AST berm was laterally bounded by samples 322A008 and 322A012 through 322A015 at sample location A04, and samples 322A016 through 322A020 at sample location A05.

Because of site-specific conditions, the sampling at this CAS was limited. The steep slope on the north side of the berm restricted sampling to the north and west, and the presence of a power substation and an aboveground diesel fuel line from the current AST to the Shaker Plant prevented additional sampling to the east of the berm. No discoloration was identified in the soil within the sheer wall north of the berm. The wall is approximately $3 \mathrm{ft}$ north of the berm perimeter, and drops approximately 50 to $60 \mathrm{ft}$ at a nearly vertical slope.

Based on these results, the nature and extent of TPH-DRO contamination at CAS 01-25-01 has been defined as being restricted to within the physical boundaries of the berm laterally, but not completely defined vertically within the berm. Additional depth sampling using such equipment as a sonic drill rig is not advisable from a safety viewpoint owing to the close proximity and steepness of the land immediately to the north of the berm. An estimate was developed and applied to the existing concentrations and depth to identify a depth at which TPH-DRO is expected to decrease to a level of one-half the PAL. This theoretical depth is $12 \mathrm{ft} \mathrm{bgs} \mathrm{(see} \mathrm{Appendix} \mathrm{A} \mathrm{for} \mathrm{further} \mathrm{explanation} \mathrm{of} \mathrm{the}$ 
estimation method used to determine this depth). Details of analytical results associated with this CAS are located in Section A.3.0.

\subsubsection{CAS 03-25-03, Mud Plant and AST Diesel Release}

This CAS is divided into Area A (the J-shaped AST berm located at the west end) and Area B (the Mud Plant located at the east end).

\subsection{Area $A$}

TPH-DRO was identified above the PAL at two locations in Area A. The first was a surface sample collected at sample location B04. The concentration of TPH-DRO was 370 milligrams per kilogram $(\mathrm{mg} / \mathrm{kg})$ at this location. TPH-DRO was not identified at other depths at this location or adjacent sample locations; therefore, the contamination is considered bounded. The soil at sample location B04 was removed to a depth of $1 \mathrm{ft}$ bgs and drummed for management as hydrocarbon waste. A confirmation sample was collected at the bottom of the excavation and determined to be free of TPH-DRO.

A second sample location with TPH-DRO contamination $(140 \mathrm{mg} / \mathrm{kg})$ was identified at 2 to $3 \mathrm{ft}$ bgs at sample location B01. No other TPH-DRO contamination was identified above the PAL vertically or laterally from this location and depth. The 2 to $3 \mathrm{ft}$ bgs interval was removed and drummed for management as hydrocarbon waste. Confirmation samples were collected from the bottom of the excavation, as well as the northwest and southeast walls of the excavation (the excavation itself ran northeast to southwest). These results were nondetect for TPH-DRO.

Historical documentation indicated the potential presence of significant TPH-DRO contamination in addition to that described above. This contamination was not encountered despite the biasing of sample locations to areas identified during previous field activities.

No contamination remains at this location. 


\subsection{Area $B$}

At area B, TPH-DRO was identified above the PAL at several locations and at varying depths. The two sample locations with the highest TPH-DRO contamination are located off the southeast corner of the Mud Plant facility and to the east-northeast along a compacted gravel roadway running between the Mud Pit Disposal Crater and the Mud Plant Pond (both described in the CADD for CAU 34). Identification of a TPH-DRO plume from any single potential source was not possible. The TPH-DRO contamination appeared highly variable in both concentration and location, both vertically and laterally. These areas of contamination have been delineated both vertically and horizontally through step-out sampling efforts within the physical constraints associated with the Mud Pit Disposal Crater located to the north and the Mud Plant Pond located to the southeast of the site. The analytical results did not suggest the presence of a TPH-DRO plume from a single source but suggested that multiple small releases and anomalies resulting from equipment fueling activities, dust suppression applications, and soil excavation/placement were the source of the contamination. Partial excavation of contaminated locations is another possible explanation for TPH-DRO presence at depth, while samples collected above these areas show no contamination. Analytical results indicate that the TPH-DRO contamination in Area B is not, as hypothesized in the CAIP, the result of TPH-DRO migration from Area A of this CAS.

Plutonium contamination was identified at one surface sample location in Area B (sample location B12). The plutonium contaminated soil was removed and drummed for waste disposal. Step-out samples collected to confirm the removal of plutonium contamination indicated no contamination above the PAL.

Based on these results, the nature and extent of COCs at CAS 03-20-05 has been defined and in accordance with the CSM. No contamination other than TPH-DRO remains in Area B. Details of analytical results associated with this CAS are located in Section A.5.0.

\subsubsection{CAS 03-20-05, Injection Wells}

No contamination was identified in association with the liquid contents of the holding tanks within the BOP Shop. However, samples collected from the central sumps in the two outer holding tanks contained two discreet layers. For analytical purposes, these were designated as an oil layer and a 
water layer by the analytical laboratory. The water layer samples collected from both sumps contains no COPCs above their respective PALs. The oil layers were essentially pure TPH. The sample from the sump in holding tank \#1 (HT-1) contains TPH-DRO at a concentration of 990,000 milligrams per liter (mg/L), and that from the sump of holding tank \#3, (HT-3) is $880,000 \mathrm{mg} / \mathrm{L}$. In addition to TPH-DRO, the samples from the two holding tank sumps also contained bis(2-ethylhexyl) phthalate at concentrations of 210,000 and $300,000 \mathrm{mg} / \mathrm{L}$ for HT-1 and HT-3, respectively. No other COPCs are identified above their respective PALs from these holding tank sumps. Based on radiological surveys, no contamination was associated with the floor of the BOP Shop, the interior of the holding tanks or their covers, or the interior of the injection well vault and its cover. No contamination was identified in association with the underground rinsate transfer line running from the BOP Shop to the injection well.

Aroclor-1254 was identified at the surface of sample location C08 at a concentration of $1.1 \mathrm{mg} / \mathrm{kg}$, and was bounded laterally and vertically.

Total petroleum hydrocarbon-DRO was identified at levels above the PAL in surface soil samples adjacent to the injection well, and the extent of contamination was bounded vertically. These surface samples contained small pieces of asphalt, and it was believed this provided the TPH-DRO results above the PAL.

Total petroleum hydrocarbon-DRO contamination was identified above the PAL at sample locations $\mathrm{C} 08$ and $\mathrm{C} 19$ at a depth of $60 \mathrm{ft}$ bgs. The TPH-DRO contamination at these locations $(730 \mathrm{mg} / \mathrm{kg}$ at $\mathrm{C} 08$ and $1,800 \mathrm{mg} / \mathrm{kg}$ at $\mathrm{C} 19)$ coincides with the approximate depth of the injection well sump. The physical configuration of the injection well was designed for the siphoning off of the lighter TPH-DRO components from liquids injected into the well casing. No other deep subsurface TPH-DRO concentration above the PAL was identified in any other of the samples taken from sample location C08 to a depth of $120 \mathrm{ft}$ bgs or C19 to a depth of $70 \mathrm{ft}$ bgs. No other TPH-DRO contamination was identified at any depth to $120 \mathrm{ft}$ bgs in samples collected from deep-subsurface borings surrounding the identified contamination and the injection well (sample locations $\mathrm{C} 11$ and $\mathrm{C} 12)$. It is believed that this contamination is a component of a lens-shaped plume of contamination that extends in all directions from the bottom of the injection well sump. 
The soil within the injection well casing was sampled at two locations to a depth of $6 \mathrm{ft}$ bgs. Additional sampling below this depth using a drill rig was not possible owing to site physical constraints as well as the structure of the drill rig itself. The soil within the injection well casing received the liquids from the holding tanks within the BOP Shop, and resided there until the level of liquid reached the top of the sump, where the lighter components of the liquid drained down the sump, or leached through the soils within the vault surrounding the sump. The semiporous material making up the soil surrounding the injection well sump to the depth investigated appeared to have allowed a significant amount of COPCs to accumulate. The soil was clearly hydrocarbon stained and emitted a musty hydrocarbon odor. Concentrations of TPH-DRO decreased with depth, ranging from $45,000 \mathrm{mg} / \mathrm{kg}$ (surface) to $6,600 \mathrm{mg} / \mathrm{kg}$ (3 to $4 \mathrm{ft} \mathrm{bgs}$ ) to $6,400 \mathrm{mg} / \mathrm{kg}$ (6 to $7 \mathrm{ft} \mathrm{bgs}$ ) at location C06, and from $35,000 \mathrm{mg} / \mathrm{kg}$ (surface) to $5,900 \mathrm{mg} / \mathrm{kg}$ (3 to $4 \mathrm{ft} \mathrm{bgs}$ ) to $3,300 \mathrm{mg} / \mathrm{kg}$ (5 to $6 \mathrm{ft} \mathrm{bgs}$ ) at location C07. Sample location C06 was from the soil beneath the underground pipe that fed liquids from the holding tanks into the injection well casing. TPH-DRO contamination was not completely bounded vertically within this boring. Because of this lack of vertical bounding, it is conservatively estimated that the TPH-DRO contamination extends in a cylindrical geometry to the depth of the injection well sump bottom (approximately $62 \mathrm{ft}$ bgs), where it becomes part of the lens-shaped plume emanating from base of the sump.

Aroclor-1254 concentrations are above the PAL in the same two surface soil samples at locations C06 and C07. The Aroclor-1254 concentration at sample location C06 is $3.3 \mathrm{mg} / \mathrm{kg}$, and $2.4 \mathrm{mg} / \mathrm{kg}$ at sample location C07. The concentrations of Aroclor-1254 decrease to below the PALs in the two samples collected beneath each surface sample location, a depth of 4 to $5 \mathrm{ft}$ bgs.

Lead is also identified above the PAL in the surface soil samples at both locations within the injection well casing. The sample location C06 showed a lead concentration of 2,500 mg/kg, and 1,500 mg/kg at sample location C07. The lead concentrations decrease to below the PALs in the two samples collected beneath each surface sample location, a depth of 4 to $5 \mathrm{ft}$ bgs.

Toxicity characteristic leaching procedure (TCLP) cadmium was identified at a concentration of $2.9 \mathrm{mg} / \mathrm{L}$, which was above the Resource Conservation and Recovery Act (RCRA) regulatory limit for toxicity of $1 \mathrm{mg} / \mathrm{L}$ at location C06 (2 to $3 \mathrm{ft} \mathrm{bgs)} \mathrm{and} 1.9 \mathrm{mg} / \mathrm{L}$ at sample location C07 (2 to $3 \mathrm{ft}$ bgs). TCLP results for samples collected below these depth intervals indicate that the TCLP 
regulatory limit is not exceeded vertically. Lateral contamination for TCLP metals was not found above the RCRA regulatory limit in any samples collected.

Plutonium $(\mathrm{Pu})-239$ was identified above the PAL in the surface sample collected at sample location $\mathrm{C} 09$. The $\mathrm{Pu}-239$ contamination is bounded both vertically and laterally. Pu-239 is also identified above the PAL in the surface sample taken at sample location C08. The Pu-239 contamination is bounded vertically, but additional $\mathrm{Pu}-239$ surface contamination was identified southeast of sample location $\mathrm{C} 08$ at sample location $\mathrm{C} 18$ and to the southwest at sample location C14. The surface soils at these locations were removed and drummed, and the material beneath the removed soils was sampled and analyzed. The drummed soil will be disposed of as low-level radioactive waste. The results for these analyses indicate the contamination was removed. There was no modification to the CSM as this surface contamination is the result of deposition from aboveground testing; therefore, not a COPC for this CAS.

Sample locations C06 and C07 also showed contamination above the PALs for Pu-239 (15 pCi/g at 2 to $3 \mathrm{ft}$ bgs and $29.1 \mathrm{pCi} / \mathrm{g}$ at 5 to $6 \mathrm{ft} \mathrm{bgs})$, americium (Am)-241 (19.7 pCi/g at 2 to $3 \mathrm{ft}$ bgs and $11.9 \mathrm{pCi} / \mathrm{g}$ at 5 to $6 \mathrm{ft} \mathrm{bgs})$, and cesium (Cs)-137 (10.1 pCi $/ \mathrm{g}$ at 5 to $6 \mathrm{ft}$ bgs). Because the vertical extent of these contaminants was not bounded, additional sampling was required. The additional samples collected to a depth of $25 \mathrm{ft}$ bgs showed contaminant levels for these parameters decreased below their respective PALs at a depth of $14 \mathrm{ft}$ bgs, and remained below their respective PALs in samples collected at 19 to 20 and 24 to $25 \mathrm{ft}$ bgs, vertically bounding these radiological contaminants.

Samples were collected from the liquid contained in the sump of the injection well. No COPCs are identified above their respective PALs. It is believed that the liquid is predominantly rainwater.

Based on these results, the nature and extent of COCs at CAS 03-20-05 has been defined. Details of analytical results associated with this CAS are located in Section A.5.0.

\subsubsection{Data Assessment Summary}

An assessment of CAU 322 investigation results determined that the data collected met the DQOs and support their intended use in the decision-making process. The assessment, provided in Appendix B, includes an evaluation of the DQIs to determine the degree of acceptability and usability of the 
reported data in the decision-making process. Additionally, a reconciliation of the data with the CSMs established for this project was conducted. Conclusions were based on results of the quality control measurements and are discussed in Appendix A and Appendix B.

The overall results of the assessment indicate that the DQI goals for precision, accuracy, completeness, representativeness, and comparability have been achieved. Precision and accuracy of the datasets were demonstrated to be within acceptable limits for a high percentage of the data. It should be noted that the percentage of acceptable laboratory control spikes was greater than 98 percent for all analyses, indicating that the low recoveries were not an analytical or laboratory problem, but may be due to matrix interference. Therefore, accuracy results for CAU 322 are considered acceptable.

Completeness objectives for this CAU have been achieved. Completeness for chemical analyses were 97 percent or better. Completeness for radiochemical analyses was 100 percent. Rejected data were thoroughly reviewed and questions concerning these data have been addressed in Appendix B. The rejected data are not considered to have adversely impacted the decision-making process.

Representativeness of site characteristics was demonstrated with the CAU 322 data. An evaluation of comparability provides high confidence that the datasets for this project are comparable to other NTS projects and other data generated by accepted industry standards. The evaluation also ensures that project data are comparable to PALs and regulatory disposal limits. Data were analyzed per SW-846 protocols, meeting specifications identified in the CAU 322 CAIP (NNSA/NSO, 2003). Achieving all of the DQI goals supports acceptance of the CAU 322 datasets; thereby, meeting the DQOs established for this project and the subsequent use of these data in the decision-making process.

\subsection{Need for Corrective Action}

Analytes detected during the corrective action investigation were evaluated against ALs to determine COCs for each CAS in CAU 322. The identification of COCs above ALs in surface and subsurface soil requires that corrective action alternatives be considered and evaluated. The impacted volume/characteristics and site-specific constraints are provided in each CAS-specific section. 


\subsubsection{CAS 01-25-01, AST Release}

One COC, TPH-DRO, was identified at CAS 01-25-01. Approximately 267 cubic yards (yd ${ }^{3}$ ) of soil within the berm's confines and extending to a depth of approximately $12 \mathrm{ft}$ bgs is contaminated with TPH-DRO at concentrations above the PAL (100 mg/kg) and up to 7,000 mg/kg. The source of the TPH-DRO is associated with AST filling operations, in which overfilling of the AST occurred regularly. If excavated, the contaminated soil would not be considered a RCRA-listed hazardous waste.

\subsubsection{CAS 03-25-03, Mud Plant and AST Diesel Release}

The need for corrective action at this CAS is addressed separately for the two areas, Area A (the AST Release) and Area B (the Mud Plant), and are presented individually in the following sections.

\subsubsection{CAS 03-25-03, Area A, AST Release}

Total petroleum hydrocarbon-DRO is the only COC identified at this CAS. TPH-DRO was identified at two locations in Area A. The contaminated soil was removed for disposal and confirmation samples collected. All confirmation samples were clean. The Area A portion of this CAS is considered clean, and no further action is required.

\subsubsection{CAS 03-25-03, Area B, Mud Plant}

Total petroleum hydrocarbon-DRO was identified at several locations at concentrations above the PAL at various depths within the Area B portion of the CAS. The random appearance of TPH-DRO contamination suggests several isolated sources. Removal of the identified TPH-DRO contamination would require the removal of large volumes of clean material in order to access the contaminated soils because the depths and locations of the contamination are widely scattered across the footprint of the area of interest.

The Pu-239 surface contamination identified during sampling was removed and drummed. Confirmation samples indicated no additional $\mathrm{Pu}-239$ contamination. 


\subsubsection{CAS 03-20-05, Injection Wells}

Analytical results from samples collected from the soil around the BOP Shop indicated some surface TPH-DRO contamination likely due to the presence of asphalt in certain sample locations. Although bounded both vertically and laterally, TPH-DRO arising from asphalt is not a COC associated with this CAS. Some surface sample locations indicated the presence of $\mathrm{Pu}-239$, which was delineated both vertically and laterally. Although not a COC associated with this CAS, the Pu-239 contamination was removed and drummed as a Best Management Practice to mitigate potential personnel exposures.

Aroclor-1254 contamination was identified above its PAL at sample location C08. Samples collected below and surrounding this sample location bound this contamination both laterally and vertically. No other contaminants were identified in the samples collected around the BOP Shop and injection well.

Soils within the injection well vault are contaminated with TPH-DRO above it PAL. These soils are also contaminated with metals, polychlorinated biphenyls (PCBs), and radionuclides above their respective PALs to a depth of $14 \mathrm{ft}$ bgs. These contaminants are bounded below this depth. The samples collected at sample locations C06 and C07 are also contaminated with TCLP cadmium at a depth of 2 to $3 \mathrm{ft}$ bgs). Samples collected below this interval are clean for this parameter.

The soils collected at a depth of $60 \mathrm{ft}$ bgs at locations C08 and C19 are contaminated with TPH-DRO above the PAL. Samples collected both above and below this sample depth are clean. It is assumed that the TPH-DRO contamination from the injection well vault soils is connected to this contamination as a cylindrically-shaped plume, as no interception of a laterally-extending plume of contamination was identified in any of the soil borings.

It is recommended that the liquids from the holding tanks and sumps within the BOP Shop and the liquids from the injection well sump be removed as a Best Management Practice. 


\subsection{Evaluation of Alternatives}

The purpose of this section is to present the corrective action objectives for CAU 214, describe the general standards and decision factors used to screen the various corrective action alternatives, and develop and evaluate a set of corrective action alternatives that will meet the corrective action objectives.

\subsection{Corrective Action Objectives}

The corrective action objectives ensure that each release site will not pose an unacceptable risk to human health and the environment and that conditions at each site are in compliance with all applicable laws and regulations. To ensure that these objectives are met, DQOs identified the information necessary to evaluate the available data against the investigation objectives. This process ensured sufficient data was collected to support the DQO decisions for each CAS. This process involved the comparison of CAI analytical data to risk-based cleanup goals defined herein as final action levels (FALs). The FALs for all the constituents detected at CAU 322 CASs are the PALs determined during the DQO process. For chemical COPCs, PALs are based on EPA Region 9 Industrial Preliminary Remediation Goals (PRGs) (EPA, 2002) and 100 milligrams per kilogram (mg/kg) for hydrocarbon-impacted soil (NAC, 2002a).

The background concentration for arsenic at NTS was used for the arsenic PAL instead of its PRG because natural concentrations at NTS exceed the Region 9 PRG. The background concentration for arsenic is considered to be the mean plus two times the standard deviation for sediment samples collected by the Nevada Bureau of Mines and Geology throughout the Nevada Test and Training Range (formerly the Nellis Air Force Range) (NBMG, 1998; Moore, 1999).

The radiological PALs are as presented in ROTC No. 1 to the CAIP (NNSA/NSO, 2003). The PALs for radiological contaminants are based on the National Council on Radiation Protection and Measurement (NCRP) Report No. 129 recommended screening limits for construction, commercial, and industrial land use scenario (NCRP, 1999) scaled from 25 to 15 millirem (mrem) per year dose and the generic guidelines for residual concentrations of radionuclides in DOE Order No. 5400.5 (DOE, 1993). 


\subsection{Screening Criteria}

The screening criteria used to evaluate and select the preferred corrective action alternatives are identified in the EPA Guidance on RCRA Corrective Action Decision Documents (EPA, 1991) and the Final RCRA Corrective Action Plan (EPA, 1994).

Corrective action alternatives are evaluated based on four general corrective action standards and five remedy selection decision factors. All corrective action alternatives must meet the general standards to be selected for evaluation using the remedy selection decision factors.

The general corrective action standards are as follows:

- Protection of human health and the environment

- Compliance with media cleanup standards

- Control the source(s) of the release

- Comply with applicable federal, state, and local standards for waste management

The remedy selection decision factors are as follows:

- Short-term reliability and effectiveness

- Reduction of toxicity, mobility, and/or volume

- Long-term reliability and effectiveness

- Feasibility

- Cost

\subsubsection{Corrective Action Standards}

The following text describes the corrective action standards used to evaluate the corrective action alternatives.

\section{Protection of Human Health and the Environment}

Protection of human health and the environment is a general mandate of the RCRA statute (EPA, 1994). This mandate requires that the corrective action include any necessary protective measures. These measures may or may not be directly related to media cleanup, source control, or management of wastes. The corrective action alternatives are evaluated for the ability to meet corrective action objectives as defined in Section 3.1. 


\section{Compliance With Media Cleanup Standards}

Each corrective action alternative must meet the proposed media cleanup standards as set forth in applicable state and federal regulations, and as specified in the CAU 322 CAIP (NNSA/NSO, 2003). For this CAU, the media cleanup standards are the FALs defined in Section 3.1.

\section{Control the Source(s) of the Release}

An objective of a corrective action remedy is to stop further environmental degradation by controlling or eliminating additional releases that may pose a threat to human health and the environment. Unless source control measures are taken, efforts to clean up releases may be ineffective or, at best, will essentially involve a perpetual cleanup. Therefore, each corrective action alternative must use an effective source control program to ensure the long-term effectiveness and protectiveness of the corrective action.

\section{Comply with Applicable Federal, State, and Local Standards for Waste Management}

During implementation of any corrective action alternative, all waste management activities must be conducted in accordance with applicable state and federal regulations (e.g., Nevada Revised Statues [NRS] 459.400-459.600, "Disposal of Hazardous Waste” [NRS, 1998]; Title 40 Code of Federal Regulations (CFR) Parts 260-282, “Hazardous Waste Management” [CFR, 2002]; and NAC 459.9974, "Disposal and Evaluation of Contaminated Soil” [NAC, 2002b]).

The requirements for management of the waste, if any, derived from the corrective action will be determined based on applicable state and federal regulations, field observations, process knowledge, characterization data, and data collected and analyzed during corrective action implementation. Administrative controls (e.g., decontamination procedures and corrective action strategies) will minimize waste generated during site corrective action activities. Decontamination activities will be performed in accordance with approved procedures and will be designated according to the COCs present at the site.

\subsubsection{Remedy Selection Decision Factors}

The following text describes the remedy selection decision factors used to evaluate the corrective action alternatives. 


\section{Short-Term Reliability and Effectiveness}

Each corrective action alternative must be evaluated with respect to its effects on human health and the environment during implementation of the corrective action. The following factors will be addressed for each alternative:

- Protection of the community from potential risks associated with implementation, such as fugitive dusts, transportation of hazardous materials, and explosion

- Protection of workers during implementation

- Environmental impacts that may result from implementation

- The amount of time until the corrective action objectives are achieved

\section{Reduction of Toxicity, Mobility, and/or Volume}

Each corrective action alternative must be evaluated for its ability to reduce the toxicity, mobility, and/or volume of the contaminated media. Reduction in toxicity, mobility, and/or volume refers to changes in one or more characteristics of the contaminated media by the use of corrective measures that decrease the inherent threats associated with that media.

\section{Long-Term Reliability and Effectiveness}

Each corrective action alternative must be evaluated in terms of risk remaining at the CAU after the corrective action alternative has been implemented. The primary focus of this evaluation is on the extent and effectiveness of the control that may be required to manage the risk posed by treatment residuals and/or untreated wastes.

\section{Feasibility}

The feasibility criterion addresses the technical and administrative feasibility of implementing a corrective action alternative and the availability of services and materials needed during implementation. Each corrective action alternative must be evaluated for the following criteria:

- Construction and Operation: Refers to the feasibility of implementing a corrective action alternative given the existing set of waste and site-specific conditions. 
- Administrative Feasibility: Refers to the administrative activities needed to implement the corrective action alternative (e.g., permits, public acceptance, rights of way, off-site approval).

- Availability of Services and Materials: Refers to the availability of adequate off-site and on-site treatment, storage capacity, disposal services, necessary technical services and materials, and prospective technologies for each corrective action alternative.

\section{Cost}

Costs for each alternative are estimated for comparison purposes only. The cost estimate for each corrective action alternative includes both capital and operation and maintenance costs, as applicable. The following is a brief description of each component:

- Capital Costs: These costs include both direct and indirect costs. Direct costs may consist of materials, labor, mobilization, demobilization, site preparation, construction materials, equipment purchase and rental, sampling and analysis, waste disposal, and health and safety measures. Indirect costs include such items as engineering design, permits and/or fees, start-up costs, and any contingency allowances.

- Operation and Maintenance: These costs include labor, training, sampling and analysis, maintenance materials, utilities, and health and safety measures.

Cost estimates for the corrective action alternatives are provided in Appendix C.

\subsection{Development of Corrective Action Alternatives}

This section identifies and briefly describes the viable corrective action technologies and the corrective action alternatives considered for the affected media at the various CASs within CAU 322. Based on the review of existing data, future use, and current operations at the NTS, the following alternatives have been developed for consideration at CAU 322:

- Alternative 1 - No Further Action

- Alternative 2 - Clean Closure

- Alternative 3 - Closure in Place with Administrative Controls

Other technologies, such as bioremediation, were considered; however, it would not be effective because of the limited volume and concentrations of contaminated material. These alternatives will not receive further consideration in this CADD. Table 3-1 summarizes the corrective action alternatives evaluated for each CAS within CAU 322. 
Table 3-1

Corrective Action Alternatives Evaluated for CAU 322

\begin{tabular}{|c|c|c|c|}
\hline Corrective Action Site & Alternative 1 & Alternative 2 & Alternative 3 \\
\hline \hline CAS 01-25-01 & $\mathrm{X}$ & $\mathrm{X}$ & $\mathrm{X}$ \\
\hline CAS 03-25-03 Area A & $\mathrm{X}$ & & $\mathrm{X}$ \\
\hline CAS 03-25-03 Area B & $\mathrm{X}$ & $\mathrm{X}$ & $\mathrm{X}$ \\
\hline CAS 03-20-05 & $\mathrm{X}$ & $\mathrm{X}$ & \\
\hline
\end{tabular}

\subsubsection{Alternative 1 - No Further Action}

Under the No Further Action Alternative, no corrective action activities will be implemented. This alternative is a baseline case, considered for all CASs, with which to compare and assess the other corrective action alternatives and their ability to meet the corrective action standards.

This alternative meets the corrective action objectives for CASs 03-25-03 Area A, where there are no COCs remaining in the soil.

\subsubsection{Alternative 2 - Clean Closure}

For contaminated surface and subsurface soil, Alternative 2 includes excavating and disposing of soil and debris containing COCs. Impacted soil will be removed. Contaminated media with activity exceeding the unrestricted release criteria will be excavated and properly disposed. A visual inspection will be conducted to ensure that debris and visible contamination have been removed. Verification soil samples will also be collected and analyzed for the presence of COCs. This will verify that the removal of COCs is complete.

Any contaminated material that is removed will be disposed of at an appropriate disposal facility. All excavated areas will be returned to surface conditions compatible with the intended future use of the site. Clean fill will be used to backfill excavations after removal of the contaminated soil. As feasible, clean borrow soil will be removed from a nearby location for placement in voids.

The following subsections provide appropriate CAS-specific information regarding Alternative 2, Clean Closure. 


\subsubsection{CAS 01-25-01 AST Release}

Alternative 2 includes removal and proper disposal of the TPH-DRO contaminated soil. Verification samples would be collected from the excavation floor and sidewalls and analyzed for site-specific COCs to ensure adequate removal of the contaminated soil. As necessary, the excavated area will be backfilled with clean soil and/or graded to satisfaction. The AST berm is located on an elevated ledge on the south side of the Shaker Plant. The northern border of the berm drops off approximately 50 to $60 \mathrm{ft}$ at a steep slope (angle of approximately 80 degrees from the edge of the berm). This severe physical feature makes removal of the contaminated soil at this location highly problematic. Removal of the contaminated soil from this location would compromise the integrity of the northern wall of the remaining berm, and the presence of any heavy equipment compressing and vibrating the soil around and within the northern wall of the berm would enhance its instability. Therefore, soil removal is not a viable option.

\subsubsection{CAS 03-25-03 Area B, Mud Plant}

Alternative 2 includes removal and proper disposal of the TPH-DRO contaminated soil. Verification samples would be collected from the excavation floor and sidewalls and analyzed for site-specific COCs to ensure adequate removal of the contaminated soil. As necessary, the excavated area will be backfilled with clean soil and/or graded. This alternative is not considered viable because of the large amount of soil that would require removal to achieve clean closure, and the added complications associated with the extensive amount of underground utilities located at this site. Additionally, two craters adjacent to Area B are closed in place with administrative controls for TPH-DRO as a result of CAU 34 investigations. Removing TPH-DRO contamination from Area B does not necessarily mean the area will be clean.

This CAS would be closed in accordance with the administrative requirements identified in NAC 445A (NAC, 2002a), as described in this section.

\subsubsection{CAS 03-20-05 Injection Wells}

Alternative 2 includes removal and proper disposal of soils contaminated with TPH-DRO and other contaminants within the injection well vault. Although feasible for the shallow subsurface 
contamination, it is not feasible to remove the TPH-DRO contamination at the $60 \mathrm{ft}$ bgs level. Therefore, Alternative 2 is not a viable option for this CAS.

\subsubsection{Alternative 3 - Close in Place with Administrative Controls}

Alternative 3 will use administrative controls to prevent inadvertent contact with chemical COCs and contaminated media with radiological activity exceeding the unrestricted release criteria. These controls would consist of use restrictions to minimize access and prevent unauthorized intrusive activities (e.g., fencing and signage). The future use of the CAS would be restricted from any activity that would alter or modify the containment control unless appropriate concurrence was obtained from NDEP. The combination of these measures will effectively prevent inadvertent intrusive activities by humans and native wildlife and the potential subsequent mobilization of COCs.

The following subsections provide appropriate CAS-specific information regarding Alternative 3, Closure in Place with Administrative Controls.

\subsubsection{CAS 01-25-01, AST Release}

Alternative 3 includes administrative activities and costs associated with the use restriction for the AST Release site. Additionally, appropriate signage around the AST berm is recommended for this alternative. This site is located within the Shaker Plant facility of the NTS Area 1.

The following evaluation of NAC 445A.227 (2) (a-k) (NAC, 2002) supports the protection of groundwater from COCs at this CAS:

a. Depth to groundwater at the nearest water supply well, UE-16d, located approximately $7,875 \mathrm{ft}$ west of the site (situated upon the western edge of Yucca Flat on Syncline Ridge), is approximately $755 \mathrm{ft}$ bgs (USGS, 2002). Groundwater flow in this region generally is from the northeast to the southwest, eventually discharging at Ash Meadows (USGS, 1996).

b. The distance to the nearest active water-supply well, UE-16d, is approximately 1.5 miles west of the site (USGS, 2002). This well is primarily used to provide drinking water for this area. Groundwater flow is generally to the southwest (DOE/NV, 1996)

c. Soil type at this CAS is typical desert alluvium composed of mostly fine soil and rock particles and includes loose rocks measuring up to 3 in. in diameter. 
d. Average annual precipitation in the vicinity of the Shaker Plant is approximately 5.51 to 6.61 in. annually (NOAA, 2002). Annual evaporation is roughly 5 to 25 times the annual precipitation. The high potential evaporation and low precipitation rates create a negative water balance for the area; therefore, no driving force associated with precipitation is available to mobilize COCs vertically.

e. TPH-DRO is present above PALs in the soil directly beneath the berm floor and is believed to have occurred as a result of years of AST overfilling.

f. TPH-DRO contamination existed to a depth of approximately $12 \mathrm{ft}$ bgs and is confined to the vertical volume beneath the berm floor.

g. Presently, CAS 01-25-01 is located on a government-controlled facility. The NTS is a restricted area that is guarded on a 24-hour, 365 day-per-year basis; unauthorized personnel are not admitted to this facility. The site is currently inactive, and no known future use of the site is identified.

h. Preferred routes of vertical and lateral migration are seepage into the native soil beneath the contaminated area. The source of the contamination has been removed, so no additional TPH-DRO is being released.

i. See Section 2.3.1 of this CADD for site-specific considerations.

j. The potential for hazard related to fire, vapor, or explosion is nonexistent for the COCs at this site.

k. No other site-specific factors are known at this site.

Based on this evaluation, impacts to groundwater are not expected from this site. Therefore, groundwater monitoring is not proposed for this site and is not considered an element of the alternatives.

\subsubsection{CAS 03-25-03 Area B, Mud Plant}

Alternative 3 includes administrative activities and costs associated with use restrictions for the storage yards. Additionally, appropriate signage around the east side of the Mud Plant is recommended for this alternative. 
The following evaluation of NAC 445A.227 (2) (a-k) (NAC, 2002a) supports the protection of groundwater from COCs at this CAS:

a. Depth to groundwater at the nearest well (USGS Water Well A, located approximately 4,515 ft southwest of the CAS) is approximately 1,610 ft bgs (Winograd and Thordarson 1975). Movement of groundwater within the Ash Meadows subbasin is to the south-southwest, towards Death Valley and Ash Meadows.

b. The distance to the nearest active water-supply well (USGS Water Well A) is approximately $4,515 \mathrm{ft}$ southwest of this CAS (USGS, 2002). This well was primarily used to provide potable water for Area 3 until 1991. Groundwater flow is generally to the south-southwest (DOE/NV, 1996).

c. Soil type at this CAS is generally compacted silty sands with gravel, typical of the desert in this area.

d. Average annual precipitation for valleys in the South-Central Great Basin ranges from 3 to 6 in. (Winograd and Thordarson, 1975). Annual evaporation is roughly 5 to 25 times the annual precipitation. The high potential evaporation and low precipitation rates create a negative water balance for the area; therefore, no driving force associated with precipitation is available to mobilize COCs vertically.

e. TPH-DRO contamination was identified above the PAL.

f. Contaminant concentrations in sampling horizons below the widespread TPH-DRO-stained soil were below PALs, demonstrating minimal vertical migration. The vertical extent of the widespread TPH-DRO contamination is varied in both concentration and location. The lateral and vertical extent of the TPH-DRO contamination is isolated such that no contaminant plume originating from an identifiable source can be ascertained. Removal of all isolated locations of TPH-DRO contamination at this CAS amounts to the removal of approximately $1,500 \mathrm{yd}^{3}$ of soil.

g. Presently, CAS 03-25-03 Area B is located on a government-controlled facility. The NTS is a restricted area that is guarded on a 24-hour, 365 day-per-year basis; unauthorized personnel are not admitted to this facility. The site is currently inactive and no known future use of the site is identified.

h. Preferred routes of vertical and lateral migration are seepage into the native soil beneath the contaminated locations. No additional source of TPH-DRO is identified at this location.

i. See Section 4.0 of this CADD for site-specific considerations. 
j. The potential for hazard related to fire, vapor, or explosion is nonexistent for the COCs at this site.

k. No other site-specific factors are known at this site.

Based on this evaluation, impacts to groundwater are not expected from this site. Therefore, groundwater monitoring is not proposed for this site and is not considered an element of the alternatives.

\subsubsection{CAS 03-20-05, Injection Wells}

Alternative 3 includes administrative activities and costs associated with use restrictions for the injection well. Additionally, appropriate signage around the injection well is recommended for this alternative.

The following evaluation of NAC 445A.227 (2) (a-k) (NAC, 2002) supports the protection of groundwater from COCs at this CAS:

a. Depth to groundwater at the nearest well (USGS Water Well A, located approximately $392 \mathrm{ft}$ northeast of the CAS) is approximately 1,610 ft bgs (Price and Thordarson 1961; Wuellner 1994). Movement of groundwater within the Ash Meadows subbasin is to the south-southwest, towards Death Valley and Ash Meadows.

b. The distance to the nearest active water-supply well (USGS Water Well A) is approximately $392 \mathrm{ft}$ northeast of this CAS (USGS, 2002). This well was primarily used to provide potable water for Area 3 until 1991 (Wuellner, 1994). Groundwater flow is generally to the south-southwest.

c. Soil type at this CAS is generally fill material composed of silty sands with gravel.

d. Average annual precipitation for valleys in the South-Central Great Basin ranges from 3 to 6 in. (Winograd and Thordarson, 1975). Annual evaporation is roughly 5 to 25 times the annual precipitation. The high potential evaporation and low precipitation rates create a negative water balance for the area; therefore, no driving force associated with precipitation is available to mobilize COCs vertically.

e. TPH-DRO, lead, Aroclor-1254, americium-221, cesium-137, and plutonium-239 were identified above their respective PALs at this CAS.

f. The nature and extent of contaminants in soil within the injection well casing have been delineated. The activities at the BOP Shop that led to the contamination no longer exist, 
precluding the addition of more contaminants. The injection well is covered, reducing the likelihood of additional contaminant migration through percolation from rainwater intrusion. The lateral extent of the contamination is isolated to the confines of the injection well casing. Removal of the contaminated soils from the injection well casing would eliminate the need to provide an impervious cap to the immediate area. It is infeasible to remove the TPH-DRO contamination at $60 \mathrm{ft}$ bgs. Removal of the radiological and metals contaminated soils from the injection well casing amounts to a depth of $14 \mathrm{ft}$ bgs and requires the removal of approximately $30 \mathrm{yd}^{3}$ of soil. However, TPH-DRO contamination will remain below $14 \mathrm{ft}$ bgs.

g. Presently, CASs 03-20-05 is located on a government-controlled facility. The NTS is a restricted area that is guarded on a 24-hour, 365 day-per-year basis; unauthorized personnel are not admitted to this facility. The site is currently inactive and no known future use of the site is identified.

h. Preferred routes of vertical and lateral migration are seepage into the native soil beneath the contaminated locations, and no additional source of contaminants has been identified at this location.

i. See Section 4.0 of this CADD for site-specific considerations.

j. The potential for hazard related to fire, vapor, or explosion is nonexistent for the COCs at this site.

k. No other site-specific factors are known at this site.

Based on this evaluation, impacts to groundwater are not expected from this site. Therefore, groundwater monitoring is not proposed for this site and is not considered an element of the alternatives.

In addition to the actions described above, Best Management Practices are also recommended for CAS 03-20-05 to eliminate the potential for environmental contamination in the future and to remove the areas of highest contamination to limit the potential for human exposure. These include:

- Removal and disposal of approximately 52 cubic yards of soil contaminated with metals, PCBs, radionuclides, and TPH-DRO, from the injection well vault and backfill to grade

- Removal and disposal of approximately 2 to 5 cubic $\mathrm{ft}$ of PCB-contaminated soil at location $\mathrm{C} 08$

- Removal and disposal of liquids from the holding tanks and the holding tank sumps 
- Grouting of the holding tanks and holding tank sumps

- Grouting of the injection well

\subsection{Evaluation and Comparison of Alternatives}

The general corrective action standards and remedy selection decision factors described in Section 3.2 were used to conduct detailed and comparative analyses of each corrective action alternative presented in Section 3.3. The advantages and disadvantages of each alternative were assessed to select preferred alternatives for CAU 322. Table 3-2 and Table 3-3 present the detailed comparative evaluation of closure alternatives for each CAS requiring corrective action. The cost estimates listed in Table 3-2 and Table 3-3 are detailed in Appendix C. 
Table 3-2

Detailed Evaluation of Alternatives for Corrective Action Unit 322 (Page 1 of 3 )

\begin{tabular}{|c|c|c|c|}
\hline Evaluation Criteria & $\begin{array}{c}\text { Alternative } 1 \\
\text { No Further Action }\end{array}$ & $\begin{array}{l}\text { Alternative } 2 \\
\text { Clean Closure }\end{array}$ & $\begin{array}{c}\text { Alternative } 3 \\
\text { Closure in Place with } \\
\text { Administrative Controls }\end{array}$ \\
\hline \multicolumn{4}{|c|}{ Closure Standards } \\
\hline $\begin{array}{l}\text { Protection of Human Health and the } \\
\text { Environment }\end{array}$ & $\begin{array}{l}\text { Does not meet corrective action } \\
\text { objective of preventing or mitigating } \\
\text { exposure to surface and subsurface } \\
\text { soil containing COCs or media } \\
\text { exceeding unrestricted release } \\
\text { criteria. } \\
\text { - Does not meet corrective action } \\
\text { objective of preventing or mitigating } \\
\text { exposure to contamination with } \\
\text { concentrations exceeding } \\
\text { unrestricted release criteria. } \\
\text { Does not prevent potential spread of } \\
\text { COCs. } \\
\text { NAC } 445.227 \text { (2) (a-k) analysis } \\
\text { shows the contaminants are not } \\
\text { expected to impact groundwater. } \\
\text { No worker exposure associated with } \\
\text { implementation. }\end{array}$ & $\begin{array}{l}\text { - Low to moderate risk to workers } \\
\text { associated with heavy equipment } \\
\text { and potential contact with impacted } \\
\text { media during excavation, } \\
\text { transportation, and closure } \\
\text { activities. } \\
\text { - Low risk to public due to remote } \\
\text { location and controlled access to } \\
\text { NTS. Low to moderate risk to public } \\
\text { during transportation off NTS. } \\
\text { NAC } 445.227 \text { (2) (a-k) analysis } \\
\text { shows the contaminants are not } \\
\text { expected to impact groundwater. } \\
\text { Moving contaminated media to an } \\
\text { appropriate disposal facility } \\
\text { mitigates exposure to impacted } \\
\text { media after closure. }\end{array}$ & $\begin{array}{l}\text { - Meets corrective action objectives. } \\
\text { - } \text { Prevents inadvertent intrusion into } \\
\text { the contaminated media. } \\
\text { heavy equipment and potential } \\
\text { contact with impacted media during } \\
\text { closure activities. } \\
\text { - Low risk to public because of } \\
\text { remote location and controlled } \\
\text { access to the NTS. } \\
\text { NAC } 445.227 \text { (2) (a-k) analysis } \\
\text { shows the contaminants are not } \\
\text { expected to impact groundwater. } \\
\text { Proposed alternative would } \\
\text { eliminate the potential exposure } \\
\text { pathway. }\end{array}$ \\
\hline $\begin{array}{l}\text { Compliance with Media Cleanup } \\
\text { Standards }\end{array}$ & $\begin{array}{l}\text { Does not comply with media } \\
\text { cleanup standards because COCs } \\
\text { exceeding unrestricted release } \\
\text { criteria remain. } \\
\text { NAC } 445.227(2)(a-k) \text { analysis } \\
\text { shows the contaminants are not } \\
\text { expected to impact groundwater. }\end{array}$ & $\begin{array}{l}\text { - Complies with media cleanup } \\
\text { standards because media } \\
\text { containing COCs will be excavated } \\
\text { and disposed of at an appropriate } \\
\text { facility. } \\
\text { - Removal of COCs will be verified } \\
\text { with confirmation sampling. } \\
\text { NAC } 445.227 \text { (2) (a-k) analysis } \\
\text { shows the contaminants are not } \\
\text { expected to impact groundwater. }\end{array}$ & $\begin{array}{l}\text { - Complies with media cleanup } \\
\text { standards by controlling exposure } \\
\text { pathways. } \\
\text { NAC } 445.227(2)(a-k) \text { analysis } \\
\text { shows the contaminants are not } \\
\text { expected to impact groundwater. }\end{array}$ \\
\hline
\end{tabular}


Table 3-2

Detailed Evaluation of Alternatives for Corrective Action Unit 322

(Page 2 of 3 )

\begin{tabular}{|c|c|c|c|}
\hline Evaluation Criteria & $\begin{array}{l}\text { Alternative } 1 \\
\text { No Further Action }\end{array}$ & $\begin{array}{l}\text { Alternative } 2 \\
\text { Clean Closure }\end{array}$ & $\begin{array}{c}\text { Alternative } 3 \\
\text { Closure in Place with } \\
\text { Administrative Controls }\end{array}$ \\
\hline Control the Source(s) of Release & $\begin{array}{l}\text { The sources of each Corrective } \\
\text { Action Site (CAS) have been } \\
\text { discontinued. }\end{array}$ & $\begin{array}{l}\text { The sources of each CAS have } \\
\text { been discontinued. }\end{array}$ & $\begin{array}{l}\text { The sources of each CAS have } \\
\text { been discontinued. }\end{array}$ \\
\hline $\begin{array}{c}\text { Comply with Applicable Federal, State, } \\
\text { and Local Standards for Waste } \\
\text { Management }\end{array}$ & - No waste generated & $\begin{array}{l}\text { All waste (primarily contaminated } \\
\text { soil, CAS components, and } \\
\text { disposable personal protective } \\
\text { equipment) will be handled and } \\
\text { disposed of in accordance with } \\
\text { applicable standards. }\end{array}$ & $\begin{array}{l}\text { All waste (primarily disposable PPE, } \\
\text { system components) will be handled } \\
\text { and disposed of in accordance with } \\
\text { applicable standards. }\end{array}$ \\
\hline \multicolumn{4}{|c|}{ Remedy Selection Decision Factors } \\
\hline $\begin{array}{l}\text { Short-Term Reliability and } \\
\text { Effectiveness }\end{array}$ & Not evaluated & $\begin{array}{l}\text { - Low risk to workers associated with } \\
\text { heavy equipment and potential } \\
\text { contact with impacted media during } \\
\text { excavation, transportation, and } \\
\text { closure activities. } \\
\text { - Public protected during removal by } \\
\text { remote location and NTS site } \\
\text { access controls. } \\
\text { - Low to moderate risk to public } \\
\text { during transportation off NTS. } \\
\text { Environmental impacts are not } \\
\text { anticipated due to implementation. } \\
\text { Appropriate measures will be taken } \\
\text { at the site to protect desert tortoises. } \\
\text { Implementation should not require } \\
\text { an extended period of time. }\end{array}$ & $\begin{array}{l}\text { - Low risk to workers associated with } \\
\text { heavy equipment and potential } \\
\text { contact with impacted media during } \\
\text { closure activities. } \\
\text { - } \text { Public protected by remote location } \\
\text { and NTS site access controls. } \\
\text { - Environmental impacts are not } \\
\text { anticipated due to implementation. } \\
\text { Appropriate measures will be taken } \\
\text { at the site to protect desert tortoises. } \\
\text { Implementation should not require } \\
\text { an extended period of time. }\end{array}$ \\
\hline
\end{tabular}


Table 3-2

Detailed Evaluation of Alternatives for Corrective Action Unit 322

(Page 3 of 3 )

\begin{tabular}{|c|c|c|c|}
\hline Evaluation Criteria & $\begin{array}{l}\text { Alternative } 1 \\
\text { No Further Action }\end{array}$ & $\begin{array}{l}\text { Alternative } 2 \\
\text { Clean Closure }\end{array}$ & $\begin{array}{c}\text { Alternative } 3 \\
\text { Closure in Place with } \\
\text { Administrative Controls }\end{array}$ \\
\hline $\begin{array}{c}\text { Reduction of Toxicity, Mobility, and/or } \\
\text { Volume }\end{array}$ & Not evaluated & $\begin{array}{l}\text { Clean closure would effectively } \\
\text { eliminate associated toxicity, } \\
\text { mobility, and volume of wastes at } \\
\text { each CAS. } \\
\text { Proper disposal of the waste will } \\
\text { result in an ultimate reduction of } \\
\text { mobility. }\end{array}$ & $\begin{array}{l}\text { The mobility of the remaining soil } \\
\text { contamination is significantly } \\
\text { reduced by administrative controls, } \\
\text { solidification of any free liquid, and } \\
\text { lack of viable driving forces. } \\
\text { - Toxicity and volume of the soil } \\
\text { contamination are effectively } \\
\text { unchanged. } \\
\text { - The mobility of the remaining } \\
\text { subsurface soil contamination is } \\
\text { significantly reduced by } \\
\text { administrative controls and lack of } \\
\text { viable driving forces. }\end{array}$ \\
\hline $\begin{array}{l}\text { Long-Term Reliability and } \\
\text { Effectiveness }\end{array}$ & Not evaluated & $\begin{array}{l}\text { - All risk will be eliminated on site } \\
\text { upon completion. } \\
\text { - No maintenance required. } \\
\text { - Moving contaminated media to an } \\
\text { appropriate disposal media facility } \\
\text { addresses the persistent adsorption } \\
\text { of contaminants. }\end{array}$ & $\begin{array}{l}\text { - Controls inadvertent intrusion to } \\
\text { remaining contaminated media. } \\
\text { - Administrative controls must be } \\
\text { maintained. }\end{array}$ \\
\hline Feasibility & Not evaluated & $\begin{array}{l}\text { Removal of contaminated media } \\
\text { requires controls to protect workers. } \\
\text { Options for disposal of } \\
\text { contaminated media is limited and } \\
\text { require coordination with multiple } \\
\text { entities. }\end{array}$ & $\begin{array}{l}\text { - Easily implemented } \\
\text { - Coordination of all entities is } \\
\text { necessary to ensure compliance } \\
\text { with administrative controls to } \\
\text { prevent intrusion into contaminated } \\
\text { zones. }\end{array}$ \\
\hline Cost & $\begin{array}{l}\text { CAS 01-25-01: } \$ 0 \\
\text { CAS 03-25-03 Areas A and B: } \$ 0 \\
\text { CAS 03-20-05: } \$ 0\end{array}$ & CAS 03-25-03 Area B: $\$ 262,078$ & $\begin{array}{l}\text { CAS 01-25-01: } \$ 22,151 \\
\text { CAS 03-25-03 Area B: } \$ 22,420 \\
\text { CAS 03-20-05: } \$ 156,591\end{array}$ \\
\hline
\end{tabular}

$\mathrm{NA}=$ Not applicable 
Table 3-3

Comparative Evaluation of Alternatives for Corrective Action Unit 322

\begin{tabular}{|c|c|c|c|}
\hline Evaluation Criteria & \multicolumn{3}{|c|}{ Comparative Evaluation } \\
\hline \multicolumn{4}{|c|}{ Closure Standards } \\
\hline $\begin{array}{l}\text { Protection of Human Health and the } \\
\text { Environment }\end{array}$ & \multicolumn{3}{|c|}{$\begin{array}{l}\text { Alternatives } 2 \text { and } 3 \text { meet corrective action objectives; Alternative } 1 \text { does not. No worker exposures to risks are } \\
\text { associated with Alternative 1. Low risks are associated with Alternative } 3 \text { and slightly higher risks with Alternative } 2 . \\
\text { Nevada Administrative Code 445A.227 (2) (a-k) analysis shows the contaminants are not threatening groundwater. }\end{array}$} \\
\hline $\begin{array}{l}\text { Compliance with Media Cleanup } \\
\qquad \text { Standards }\end{array}$ & \multicolumn{3}{|c|}{$\begin{array}{l}\text { Alternative } 1 \text { does not comply with media cleanup standards. Alternative } 2 \text { meets media cleanup standards by removing } \\
\text { contaminated soil and CAS components exceeding unrestricted release criteria and eliminating exposure pathways at the } \\
\text { site. Alternative } 3 \text { controls access to contaminants, effectively eliminating exposure pathways. }\end{array}$} \\
\hline Control the Source(s) of Release & \multicolumn{3}{|c|}{ The sources at each Corrective Action Site (CAS) have been discontinued. } \\
\hline $\begin{array}{l}\text { Comply with Applicable Federal, State, } \\
\text { and Local Standards for Waste } \\
\text { Management }\end{array}$ & \multicolumn{3}{|c|}{$\begin{array}{l}\text { Alternative } 1 \text { does not generate waste. Alternatives } 2 \text { and } 3 \text { will generate waste that will be handled in accordance with } \\
\text { applicable standards. }\end{array}$} \\
\hline \multicolumn{4}{|c|}{ Remedy Selection Decision Factors } \\
\hline $\begin{array}{l}\text { Short-Term Reliability and } \\
\text { Effectiveness }\end{array}$ & \multicolumn{3}{|c|}{ Low risks are associated with Alternative 3 and slightly higher risks with Alternative 2.} \\
\hline $\begin{array}{l}\text { Reduction of Toxicity, Mobility, and/or } \\
\text { Volume }\end{array}$ & \multicolumn{3}{|c|}{$\begin{array}{l}\text { Alternative } 2 \text { results in an immediate reduction of all three characteristics at each CAS. Alternative } 3 \text { results in a reduction } \\
\text { of mobility, but does not reduce toxicity or volume. Worker exposure to risks associated with Alternative } 2 \text {. }\end{array}$} \\
\hline $\begin{array}{l}\text { Long-Term Reliability and } \\
\text { Effectiveness }\end{array}$ & \multicolumn{3}{|c|}{$\begin{array}{l}\text { Residual risk at each CAS is low for Alternative } 3 \text { and nonexistent for Alternative 2. Alternative } 3 \text { requires administrative } \\
\text { measures to control intrusive activities. }\end{array}$} \\
\hline Feasibility & \multicolumn{3}{|c|}{$\begin{array}{l}\text { Alternatives } 2 \text { and } 3 \text { are feasible; however, Alternative } 2 \text { will be more resource intensive, and beyond the capability of } \\
\text { current technology to remove deep ( } 60 \mathrm{ft} \text { bgs) contamination efficiently and cost effectively. }\end{array}$} \\
\hline Cost & $\begin{array}{l}\text { CAS 01-25-01: } \$ 0 \\
\text { CAS 03-25-03, Area A: } \$ 0 \\
\text { CAS 03-25-03, Area B: } \$ 0 \\
\text { CAS 03-20-05: } \$ 0\end{array}$ & CAS 03-25-03, Area B: $\$ 262,078$ & $\begin{array}{l}\text { CAS 01-25-01: } \$ 22,151 \\
\text { CAS 03-25-03, Area B: } \$ 22,420 \\
\text { CAS 03-20-05: } \$ 156,591\end{array}$ \\
\hline
\end{tabular}

$\mathrm{NA}=$ Not applicable 


\subsection{Recommended Alternatives}

The preferred corrective action alternatives were evaluated on their technical merit with focus on performance, reliability, feasibility, and safety. The selected alternatives were judged to meet all requirements for the technical components evaluated. The selected alternatives meet all applicable state and federal regulations for closure of the sites and will minimize potential future exposure pathways to the contaminated media at CAU 322. Cost estimates, and in one case safety and site stability considerations, were used to support the selection of preferred corrective action alternatives.

Alternative 1, No Further Action, is the preferred corrective action for the following CAS:

- None

Alternative 2, Clean Closure, is the preferred corrective action for the following CAS:

- None

Alternative 3, Closure in Place with Administrative Controls, is the preferred corrective action for the following CASs:

- CAS 01-25-01, AST Berm - Because of safety and site stability concerns, this corrective action was selected. Owing to its isolated location, access to the CAS is easily limited by administrative controls. Because there is no current source of additional contamination, natural bioattenuation is expected to be a factor in reducing contamination over time. Administrative controls will be implemented for the remaining TPH-DRO contamination.

- CAS 03-25-03, Area B - Even though CAS 03-25-03 Area A, AST Berm does not contain contamination, the presence of contamination at Area B, the Mud Plant, and the requirement that the corrective action alternative applies to the entire CAS, a corrective action is required at this CAS. This corrective action was selected because of the nature of occurrence of TPH-DRO contamination at this CAS, in addition to the large footprint of the area of interest and the extensive network of underground utilities. As there is no identifiable isolated source of TPH-DRO contamination and no identifiable continued source of TPH-DRO contamination, natural bioattenuation is expected to be a significant factor in reducing contamination over time. In addition, TPH-DRO contamination will remain in the surrounding craters identified as contaminated in CAU 34. Administrative controls will be implemented for the remaining TPH-DRO contamination. 
- CAS 03-20-05, Injection Wells - Because of the depth of the TPH-DRO contamination associated with the injection well, Alternatives 1 and 2 are necessarily excluded. It is unreasonable to remove the TPH-DRO contamination from this depth. As a Best Management Practice the following actions will be taken to reduce the potential for further contamination and to reduce the risk to human health and the environment to acceptable levels:

- Removal of the higher toxicity soil associated with the lead, TCLP cadmium, Aroclor-1254, Am-241, Pu-239, and Cs-137, and higher levels of TPH-DRO contamination in the soils within and directly below the injection well vault (represented by sample locations $\mathrm{C} 06$ and $\mathrm{C} 07$ ) to a depth of at least $10 \mathrm{ft}$ bgs, followed by backfilling the void created from the removed soil

- Removal of a 2 by $2 \mathrm{ft}$ area approximately $1 \mathrm{ft}$ deep to ensure complete removal of Aroclor-1254 at sample location C08 (the borehole at C08 is grouted to a depth of $120 \mathrm{ft}$ bgs; some of the surface grouting will require removal as well)

- Grout the injection well sump

- Grout the holding tank sumps and the holding tanks themselves

Implementation of corrective actions at any of these CASs may potentially present risks to site workers and equipment. 


\subsection{References}

CFR, see Code of Federal Regulations.

Code of Federal Regulations. 2002. Title 40 CFR Parts 260 - 282, "Hazardous Waste Regulations." Washington, DC: U.S. Government Printing Office.

DOE, see U.S. Department of Energy.

DOE/NV, see U.S. Department of Energy, Nevada Operations Office.

EPA, see U.S. Environmental Protection Agency.

FFACO, see Federal Facility Agreement and Consent Order.

Federal Facility Agreement and Consent Order. 1996 (as amended). Agreed to by the State of Nevada, the U.S. Department of Energy, and the U.S. Department of Defense.

Moore, J., Science Applications International Corporation. Las Vegas. 1999. Memo to M. Todd (ITLV) entitled, "Background Concentrations for NTS and TTR Soil Samples," 3 February. Las Vegas, NV.

NAC, see Nevada Administrative Code.

NCRP, see National Council on Radiation Protection and Measurements.

NMBG, see Nevada Bureau of Mines and Geology.

NNSA/NSO, see U.S. Department of Energy, National Nuclear Security Administration Nevada Site Office.

NOAA, see National Oceanic and Atmospheric Administration.

NRS, see Nevada Revised Statutes.

National Council on Radiation Protection and Measurements. 1999. Recommended Screening Limits for Contaminated Surface Soil and Review of Factors Relevant to Site-Specific Studies, Report No. 129. Bethesda, MD.

National Oceanic and Atmospheric Administration. 2002. "Precipitation Summary." As accessed at http://www.sord.nv.doe.gov/home_climate.httm on 13 November.

Nevada Administrative Code. 2002a. NAC 445A, "Water Controls." Carson City, NV. 
Nevada Administrative Code. 2002b. NAC 459, "Hazardous Materials.” Carson City, NV.

Nevada Bureau of Mines and Geology. 1998. Mineral and Energy Resource Assessment of the Nellis Air Force Range, Open-File Report 98-1. Reno, NV.

Nevada Revised Statutes. 1998. NRS 459.400-459.600, “Disposal of Hazardous Waste.” Carson City, NV.

USGS, see U.S. Geological Survey.

U.S. Department of Energy. 1993. DOE Order 5400.5 Change 2, "Radiation Protection of the Public and the Environment." Washington, D.C.

U.S. Department of Energy, National Nuclear Security Administration Nevada Operations Office. 2002. Industrial Sites Quality Assurance Project Plan, Nevada Test Site, Nevada, Rev. 3, DOE/NV-372. Las Vegas, NV.

U.S. Department of Energy, National Nuclear Security Administration Nevada Site Office. 2003. Corrective Action Investigation Plan for Corrective Action Unit 322: Areas 1 and 3 Release Sites and Injection Wells, Nevada Test Site, Nevada, Rev. 0, DOE/NV--901. Las Vegas, NV.

U.S. Department of Energy, Nevada Operations Office. 1994. Project Management Plan, Rev. 0. Las Vegas, NV.

U.S. Department of Energy, Nevada Operations Office. 1996. Final Environmental Impact Statement for the Nevada Test Site and Off-Site Locations in the State of Nevada, DOE/EIS-0243. Las Vegas, NV.

U.S. Environmental Protection Agency. 1991. Guidance on RCRA Corrective Action Decision Documents, EPA/540/G-91/011. Washington, DC: Office of Research and Development.

U.S. Environmental Protection Agency. 1994. Final RCRA Corrective Action Plan, EPA/520-R-94-004. Washington, DC: Office of Solid Waste and Emergency Response.

U.S. Environmental Protection Agency. 2000. Data Quality Objectives Process for Hazardous Waste Site Investigations, EPA/600/R-00/007. Washington, DC: Office of Environmental Information.

U.S. Environmental Protection Agency. 2002. Region IX Preliminary Remediation Goals (PRGs). As accessed at www.epa.gov/region09/waste/sfund/prg/index.htm on 8 January. Prepared by S.J. Smucker. San Francisco, CA.

U.S. Geological Survey. 2002. "USGS/DOE Nevada Water Use Wells," as accessed at http://nevada.ugsgs.gov/doe_nv/wateruse/ on 19 June. 
CAU 322 CADD

Section: 5.0

Revision: 0

Date: December 2004

Page 43 of 43

Winograd, I.J., and W. Thordarson. 1975. Hydrologic and Hydrochemical Framework

South-Central Great Basin, Nevada-California, with Special Reference to the Nevada Test Site, USGS Professional Paper 712C. Washington, DC: U.S. Government Printing Office. 


\section{Appendix A}

Corrective Action Investigation Results for CAU 322 


\section{A.1.0 Introduction}

This appendix details corrective action investigation activities and analytical results for CAU 322. Corrective Action Unit 322 is located in Areas 1 and 3 of the NTS (Figure 1-1 of the main document), and is comprised of the three CASs listed below:

- $01-25-01$, AST

- 03-25-03, AST and Mud Plant

- 03-20-05, Injection Well

Corrective Action Site 01-25-01 is located in Area 1 of the NTS and consists of a release from an AST that once contained diesel fuel.

Corrective Action Site 03-25-03 is located in Area 3 of the NTS, in an area referred to as the Mud Plant and AST Diesel Release, and consists of two distinct release sites: Area A which consists of a release from an AST and fueling station west of the Mud Plant and Area B which consists of multiple potential releases in the area immediately to the east of the Mud Plant where diesel-fueled equipment and heavy vehicular traffic once resided.

Corrective Action Site 03-20-05 is located in Area 3 and consists of potential releases from the operations at the Lawrence Livermore National Laboratory (LLNL) BOP Shop including three in-ground cleaning/holding tanks and an injection well located approximately $65 \mathrm{ft}$ from the southeast corner of the BOP Shop. Two of the three cleaning/holding tanks and the injection well are posted as containing "Underground Radiation".

This CAU was investigated because process knowledge indicated the associated CASs were the site of fuel spillage and/or radiation contamination at levels that may be considered to be hazardous or radioactive waste by current standards. The CAI was conducted in accordance with the CAU 322 CAIP as developed under the FFACO (1996).

Additional information regarding the history of each site, planning, and the scope of the investigation is presented in the CAU 322 CAIP (NNSA/NSO, 2003a). 


\section{A.1.1 Project Objectives}

The primary objective of the investigation was to provide sufficient information and data to develop appropriate corrective action alternatives for each CAS in CAU 322. This objective was achieved by identifying the absence or presence of COPCs, the nature of the COCs (i.e., COPCs at concentrations above PALs), and the vertical and lateral extent of the COCs.

The selection of soil and/or waste characterization sample locations was based on site conditions, and the strategy developed during the DQO process as outlined in the CAU 322 CAIP. The sampling strategy primarily involved bias sample locations.

\section{A.1.2 Content}

This appendix contains information and data in sufficient detail to support the selection of a preferred corrective action alternative in the CADD. The contents of this appendix are as follows:

- Section A.1.0 describes the investigation background, objectives, and content

- Section A.2.0 provides an investigation overview

- Section A.3.0 through Section A.5.0 provides CAS-specific information regarding the field activities, sampling methods, and laboratory analytical results from investigation sampling

- Section A.6.0 summarizes waste management activities

- Section A.7.0 discusses the quality assurance (QA) and QC procedures followed and results of the QA/QC activities

- Section A.8.0 is a summary of the investigation results

- Section A.9.0 lists the cited references

The complete field documentation and laboratory data, including field activity daily logs (FADLs), sample collection logs (SCLs), analysis request/chain-of-custody forms (AR/COCs), soil sample descriptions, laboratory certificates of analyses, analytical results, and surveillance results are retained in project files as hard copy files or electronic media. 


\section{A.2.0 Investigation Overview}

Field investigation and sampling activities for the CAU 322 CAI were conducted from April 12 through September 16, 2004. Table A.2-1 lists the CAI activities conducted at each of the CASs.

Table A.2-1

Corrective Action Investigation Activities Conducted at Each Corrective Action Site to Meet Corrective Action Investigation Plan Requirements

\begin{tabular}{|c|c|c|c|}
\hline \multirow[b]{2}{*}{ Corrective Action Investigation Activities } & \multicolumn{3}{|c|}{ Corrective Action Site } \\
\hline & \begin{tabular}{l}
$\overleftarrow{o}$ \\
ஸे \\
\multirow{1}{0}{} \\
$\frac{1}{0}$
\end{tabular} & 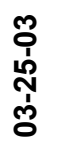 & $\begin{array}{l}\text { o̊ } \\
\text { o̊ } \\
\text { ஸે }\end{array}$ \\
\hline Inspected CAS system components & $\mathrm{X}$ & $\mathrm{X}$ & $\bar{X}$ \\
\hline Conducted surface land area radiological surveys & $\mathrm{X}$ & $\mathrm{X}$ & $\mathrm{x}$ \\
\hline Collected biased soil samples & $\mathrm{X}$ & $\mathrm{X}$ & $\mathrm{x}$ \\
\hline Field screened samples for alpha and beta/gamma radiation & $\mathrm{X}$ & $\mathrm{X}$ & $\mathrm{x}$ \\
\hline $\begin{array}{l}\text { Field screened soil samples for volatile organic compounds (Decision I } \\
\text { sampling only) }\end{array}$ & $\mathrm{X}$ & & \\
\hline $\begin{array}{l}\text { Field screened soil samples for total petroleum hydrocarbons via on-site } \\
\text { gas chromatograph }\end{array}$ & $\mathrm{X}$ & $\mathrm{X}$ & $\mathrm{X}$ \\
\hline Submitted select samples for off-site laboratory analysis & $\mathrm{X}$ & $\mathrm{X}$ & $\mathrm{x}$ \\
\hline $\begin{array}{l}\text { Removed minor surface and near surface contamination and collected } \\
\text { confirmation samples }\end{array}$ & & $\mathrm{X}$ & $x$ \\
\hline Conducted waste characterization sampling & & & $\bar{x}$ \\
\hline Performed swipe sampling for removable radioactivity and/or metals & & $\mathrm{X}$ & $\bar{x}$ \\
\hline
\end{tabular}

The investigation and sampling program was managed in accordance with the requirements set forth in the CAU 322 CAIP (NNSA/NSO, 2003a). Field activities were performed in accordance with the approved CAU 322 site-specific health and safety plan (SNJV, 2003) which is consistent with the DOE Integrated Safety Management System. Samples were collected and documented following approved protocols and procedures indicated in the CAU 322 CAIP (NNSA/NSO, 2003a). Quality control samples (e.g., field blanks, equipment rinsate blanks, trip blanks, and duplicate samples) were collected as required by the Industrial Sites Quality Assurance Project Plan (QAPP) (NNSA/NV, 2002) and approved procedures. During field activities, waste minimization practices were followed according to approved procedures, including segregation of waste by waste stream. 
Weather conditions at the site varied to include sun (moderate to high temperatures), rain, intermittent cloudiness, and light to strong winds. Winds and storms (accompanied by lightening) occasionally delayed site operations.

The CASs were investigated by various combinations of sampling potential contaminant sources, radiological surface screening and surveys, and surface and subsurface soil sampling. Surface soil samples were collected by hand. Subsurface soil samples were collected using hand augering and drilling operations. Investigation intervals and soil samples were field screened for VOCs, alpha and beta/gamma radiation, and TPH at specific locations. The results were compared against screening levels to guide in the CAS-specific investigations. Samples were shipped to off-site laboratories to be analyzed for appropriate chemical and radiological parameters.

Except as noted in the following CAS-specific sections, CAU 322 sampling locations were accessible and sampling activities at planned locations were not restricted by buildings, storage areas, active operations, or aboveground/underground utilities. Required sampling step-out locations were accessible and remained within anticipated spatial boundaries except where otherwise noted.

Section A.2.1 through Section A.2.7 provide the investigation methodology, site geology and hydrology, and laboratory analytical information. Additional activity-specific details for the individual CASs are presented in Section A.3.0 through Section A.5.0.

\section{A.2.1 Preliminary Conceptual Models}

The revised conceptual site models for CAU 322 are generally consistent with the preliminary conceptual site models provided in the CAU 322 CAIP. Variations to the CSMs are discussed in detail in the CAS-specific sections.

\section{A.2.2 Sample Locations}

Investigation locations selected for sampling were based on interpretation of existing engineering drawings, aerial and land photographs, interviews with former and current site employees, information obtained during site visits, and site conditions as provided in the CAU 322 CAIP. Sampling points for each site were selected based on the approach provided in the CAIP. The planned biased sample locations are discussed in text and shown on figures in the CAIP. All actual 
sample locations are depicted on the figures included in Section A.3.0 through Section A.5.0. Some locations were modified slightly from planned positions due to field conditions and observations. In some cases, field-screening results (FSR) and/or laboratory analytical results determined the need for step-out sampling locations. Sample locations were staked, labeled appropriately, and surveyed with a GPS instrument. The actual locations have been plotted based on the coordinates collected by the GPS instrument. In addition to the sampling locations, the figures in Appendix D of this document show points of interest with their associated GPS coordinates.

\section{A.2.2.1 Housekeeping Removal of Debris}

Before the CAU $322 \mathrm{CAI}$, removal and/or disposition of housekeeping items were performed at CAS 03-20-05. Animal waste was removed from the interior of the LLNL BOP Shop, and vegetation surrounding the injection well and adjacent to the east side of the BOP Shop building was removed.

\section{A.2.3 Investigation Activities}

The investigation activities performed at CAU 322 were based on general field investigation activities discussed in the CAU 322 CAIP (NNSA/NSO, 2003a). The technical approach consisted of the activities listed in Section A.2-1. The investigation strategy allowed the nature and extent of contamination associated with each CAS to be established. The following sections describe the specific investigation activities that took place at CAU 322.

\section{A.2.3.1 Surface Radiological Surveys}

Surface radiological land surveys were performed on all thee CASs within CAU 322 during the CAI. The surveys were performed to identify the presence and extent of surficial beta/gamma-emitting radiological contaminants at activities statistically greater than background. This was done using a TSA Model PRM-470B scintillation detector in conjunction with a Trimble Pathfinder Pro XRS ${ }^{\mathrm{TM}}$ Global Positioning Receiver with $\mathrm{TSCI}^{\mathrm{TM}}$ Datalogger. The CASs surveyed were:

- CAS 01-25-01

- CAS 03-25-03

- CAS 03-20-05 
The radiological land area survey for these CASs generally did not indicate the presence of radiological contamination above background levels.

\section{A.2.3.2 Site Walk-Overs}

Site walkovers were performed on the CASs within CAU 322. Observations were made to identify biased sampling locations (e.g., stained soil, unidentified or out-of-place objects).

\section{A.2.3.3 Field Screening}

Field-screening activities for VOCs, TPH, and alpha and beta/gamma radiation were performed as specified in the CAU 322 CAIP. The field-screening level (FSL) for VOC headspace was established at 20 ppm or 2.5 times background, whichever was greater. The TPH FSL was established at 75 ppm. Site-specific FSLs for alpha and beta/gamma radiation were defined as the mean background activity level plus two times the standard deviation of readings from 10 background locations selected near each CAS. The radiation FSLs are instrument-specific and were established for each instrument and CAS prior to use.

All field screening for VOCs was conducted using a flame ionization detector (FID) during Decision I activities at all CASs. Alpha and beta/gamma radiation screening was performed at each CAS using a handheld alpha and beta/gamma survey instrument. Field screening for TPH was conducted using a SRI Gas Chromatograph.

The CAS-specific sections of this document identify the CASs where field screening was conducted and how the FSLs were used to aid in the selection of sample locations. Field-screening results are recorded on sample collection logs that are retained in project files.

\section{A.2.3.4 Surface and Subsurface Sampling}

Intrusive investigation activities (i.e., surface and subsurface soil sampling), were conducted at all CASs within CAU 322 to support Decision I and Decision II investigation activities. Soil samples were collected using "scoop and trowel" (surface hand-grab sampling), hand auger, backhoe, and rotosonic drilling. Field screening for alpha and beta/gamma radiation was conducted during sample collection to both guide the investigation and serve as a health and safety control to protect the 
sampling team. Labeled sample containers were filled according to the following sequence: total VOCs and TPH-gasoline-range organics (GRO) sample containers were filled with soil directly from the surface location, backhoe bucket, or core bag, followed by the collection of soil for VOC field screening using headspace analysis as appropriate. Additional soil was transferred into an aluminum pan, homogenized, and field screened for alpha and beta/gamma radiation. All remaining sample containers were then filled. Excess soil was returned to its original location.

Surface soil samples were collected from 0.0 to $0.5 \mathrm{ft}$ bgs at biased locations focusing on stained soil, potential effluent locations, or areas with elevated radiological measurements. Subsurface soil samples were collected as a continuation at a surface soil sample location where staining was noted and/or analytical results indicated contamination.

\section{A.2.3.4.1 Surface Radiological Surveys and Swiping}

To support unrestricted release determinations per the NV/YMP Radiological Control Manual (DOE/NV, 2000), radiological surveys were performed at all CASs using a NE Technology Electra with dual-alpha and beta/gamma radiation scintillation probe. Swipe samples were also collected for determination of removable activity at the injection well, holding tanks, BOP Shop floor, and all lids covering the tanks and well at CAS 03-20-05. Both the surveys and swipe samples indicated all surfaces met unrestricted release criteria (Alderson, 2004). A datalogger was used to measure radiation levels at 10-ft intervals within the injection well sump, to the liquid level depth of $62 \mathrm{ft}$ bgs. The interior walls of the holding tanks within the BOP Shop, and the interior walls of the casing surrounding the injection well were also screened using swipe samples. The analytical results of the swipe samples are presented in Section A.4.0.

\section{A.2.3.4.2 Waste Characterization and Sampling}

Characterization of CAS-specific soils and liquids was performed to support disposal of these items during anticipated closure activities. The information collected at CAS 03-20-05 was used to determine if the holding tank/sump and injection well sump liquids in question could be acting as a source of potential soil contamination. Investigation methods included visual inspection, radiological surveys, swipe sample collection, and direct sampling of feature contents. Waste characterization 
activities were intended to gather adequate information and data about the CAS to support decisions regarding the disposal of materials located within the CAS.

Samples were analyzed in accordance with the procedures specified in the CAU 322 CAIP. The specific analyses for CAS 03-20-05 are listed and the analytical results are compared to the Federal limits for hazardous waste (40 CFR 261 [CFR, 2002]), NDEP hydrocarbon action limit, landfill acceptance criteria, and the limits in the NTS performance objective criteria (POC) (BN, 1995). The POC limits have been established for NTS hazardous waste generators to ensure that all hazardous waste being shipped off-site contains no "added radioactivity."

Specific waste characterization sampling and analysis were conducted on the following potential waste streams at CAS 03-20-05:

- Liquid contents of the holding tanks within the BOP Shop

- Liquid contents of the holding tank sumps within the BOP Shop

- Liquid within the injection well sump

\section{A.2.3.4.3 Sample Location Documentation}

A GPS instrument was used for determining the sample location coordinates as well as CAS points of interest. Appendix D presents this data in both tabular and graphic forms.

\section{A.2.4 Laboratory Analytical Information}

Chemical and radiological analyses were performed by Paragon Analytics, Inc., Fort Collins, Colorado. The analytical parameters and laboratory analytical methods used to analyze investigation samples are listed in Table A.2-2. Organic and inorganic analytical results are reported in this appendix if they were detected at or above the minimum reporting levels (MRLs) established in Table 3-3 of the CAU 322 CAIP (NNSA/NSO, 2003a). Radionuclide analytical results are reported in this appendix if they are detected at or above minimum detectable concentrations (MDCs).

Validated analytical data for CAU 322 investigation samples have been compiled and evaluated to confirm the presence of contamination and define the extent of contamination, if present. The analytical results for each CAS are presented in Section A.3.0 through Section A.5.0. The analytical results have been compared to MRLs or MDCs as appropriate, and only those above MRLs or MDCs 
Table A.2-2

\section{Laboratory Analytical Parameters and Methods,} CAU 322 Investigation Samples

\begin{tabular}{|c|c|}
\hline Analytical Parameter & Analytical Method \\
\hline Total volatile organic compounds & SW-846 8260B ${ }^{a}$ \\
\hline Total semivolatile organic compounds & SW-846 8270C ${ }^{a}$ \\
\hline Total petroleum hydrocarbons - gasoline-range organics & \multirow{2}{*}{ SW-846 8015B (modified) ${ }^{a}$} \\
\hline Total petroleum hydrocarbons - diesel-range organics & \\
\hline Polychlorinated biphenyls & SW-846 $8082^{a}$ \\
\hline $\begin{array}{l}\text { Total Resource Conservation and Recovery Act (RCRA) } \\
\text { metals }^{\text {b }}\end{array}$ & \multirow{2}{*}{$\begin{array}{l}\text { Water - SW-846 6010B/7470A }{ }^{a} \\
\text { Soil - SW-846 6010B/7471A }{ }^{a}\end{array}$} \\
\hline Total Beryllium & \\
\hline $\begin{array}{l}\text { Toxicity characteristic leaching procedure (TCLP) } \\
\text { volatile organic compounds }\end{array}$ & SW-846 1311/8260B ${ }^{a}$ \\
\hline TCLP semivolatile organic compounds & SW-846 1311/8270C ${ }^{a}$ \\
\hline TCLP RCRA metals ${ }^{b}$ & SW-846 1311/6010B/7470A \\
\hline Tritium & Paragon Method 754/704 \\
\hline Gamma-Emitting Radionuclides & $\begin{array}{l}\text { Water - EPA } 901.1 \\
\text { Soil - HASL-300 }\end{array}$ \\
\hline Isotopic Uranium & $\begin{array}{l}\text { Water - ASTM D3972-02 } \\
\text { Soil - ASTM C1000-00 }\end{array}$ \\
\hline Isotopic Plutonium & $\begin{array}{l}\text { Water - ASTM D3865-02 } \\
\text { Soil - ASTM C1001-90 }\end{array}$ \\
\hline Strontium-90 & $\begin{array}{l}\text { Water - ASTM D5811-00 } \\
\text { Soil - HASL-300 }\end{array}$ \\
\hline
\end{tabular}

aU.S. Environmental Protection Agency (EPA), Test Methods for Evaluating Solid Waste, Physical/Chemical Methods, 3rd Edition, Parts 1-4, SW-846 CD ROM. Washington, DC. (EPA, 1996)

${ }^{b}$ Arsenic, barium, cadmium, chromium, lead, mercury, selenium, and silver

are included in CAS-specific tables. The complete laboratory data packages are available in the project files.

The analytical parameters are CAS-specific and were selected through the application of site process knowledge according to the EPA's Guidance for the Data Quality Objectives Process (EPA, 1994b). Samples collected during step-out sampling were only analyzed for the COPCs that exceeded PALs in the original samples. Bioassessment samples were not collected because FSRs and observations did not indicate the need. 


\section{A.2.5 Comparison to Action Levels}

Chemicals and radionuclides detected in samples at concentrations greater than ALs are identified as COCs. If COCs are present, corrective action must be considered for the CAS. The PALs for the CAU 322 investigation were identified and agreed to during the DQO process. The FALs are defined in Section 3.1 of this CADD.

Sample data that exceed MRLs are tabulated in the CAS-specific sections that follow. Results that are greater than FALs (a subset of those that exceed MRLs) are identified by bold text in the corresponding tables and discussed in Section A.3.0 through Section A.5.0.

Nondetected results and results below MRLs have been excluded to minimize the size of this document. However, the unedited dataset for CAU 322 is retained in an electronic format in the project files.

\section{A.2.6 Geology}

Regional native surface soil consists of poorly graded, moderately consolidated, alluvial silty sands with gravel, and some cobble-sized volcanic and sedimentary detritus. Subsurface soil ranged from gravelly sands with fines to well-graded sands. The percentage of organic matter in the soil is low and decreases with depth beyond the native soil interface.

Auger refusal (buried railroad tie) was encountered during hand-auger sampling at CAS 01-25-01 at locations A01 and A02 at a depth of 30 in. bgs at each location. However, a backhoe was able to unearth the railroad tie and soil samples were collected at deeper intervals.

A general field description for each sample was recorded on SCLs. A more detailed description of the regional geology for the NTS is provided in the CAU 322 CAIP (NNSA/NSO, 2003a).

\section{A.2.7 Hydrology}

Dry washes provide channels that concentrate surface runoff; however, there is no perennial stream flow in the region. Surface topography at the CAU 322 CASs range from generally flat at CASs 03-25-03 and 03-20-05 to steeply sloping outside the AST berm at CAS 01-25-01. 
Due to the depth to groundwater and climatic conditions, groundwater at the NTS in Areas 1 and 3 is not expected to have been impacted by COPCs. In Area 1, the depth to groundwater is estimated to be $750 \mathrm{ft}$ bgs based on depth to water found at the UE-16d Eleana Water Well located some 3,000 ft from the CAS. In Area 3, the closest well is designated as USGS Water Well A, and the depth to water here is approximately 1,610 ft bgs. (Winograd and Thordarson, 1975).

No saturated zones (e.g., perched water, contaminant saturation) were found anywhere in the subsurface adjacent to or below the CASs, nor were saturated intervals identified during sampling activities.

Potential evapotranspiration at the NTS is significantly greater than precipitation, thus limiting vertical migration of contaminants. The annual average precipitation for the area associated with all CASs within CAU 322 is approximately 5.5 to 6.6 in. per year (DRI, 1985). The potential annual evaporation is the dominant factor influencing the movement of water in the upper saturated zone. Therefore, recharge to groundwater from precipitation is not significant at the NTS and does not provide a significant mechanism for migration of contaminants to groundwater. 


\section{A.3.0 CAS 01-25-01, AST Release}

The location of the former AST is located in Area 1 of the NTS, within the boundaries of the Shaker Plant, and is located in the northern portion of the plant grounds. The berm in which the AST was located is constructed of earth and gravel, and the berm floor contains several pieces of large wooden plyboard for tank support. Additional pieces of heavy railroad ties were discovered under the berm floor surface while conducting backhoe excavation. The berm once contained a 10,000 gallon diesel fuel AST, which has been relocated to a concrete berm approximately $40 \mathrm{ft}$ to the southeast of the CAS. The AST once provided fuel to the Shaker Plant for its operation. The terrain surrounding the AST drops off steeply to the entire north side of the berm. Drop-offs of a less severe sloping also occur to the west and southwest of the AST. The pipeline running from the current AST location to the Shaker Plant and an electrical substation bound the CAS immediately to the east. Additional detail is provided in the CAIP (NNSA/NSO, 2003a).

\section{A.3.1 Corrective Action Investigation}

A total of 20 soil samples (including 2 field duplicates) were collected during investigation activities at CAS 01-25-01. The sample identification numbers (IDs), locations, types and analyses are listed in Table A.3-1. The sample locations are shown on Figure A.3-1. The specific CAI activities conducted to satisfy the CAIP requirements at this CAS are described in the following sections.

\section{A.3.1.1 Deviations}

There were no significant deviations to the CAIP requirements at this CAS. However, the visual assessment of the site during sampling activities and field screening analyses indicated the presence of TPH-DRO contamination within the floor of the berm. The sampling strategy was altered to account for this evidence. All samples submitted to the laboratory from this CAS were requested to be analyzed for TPH-DRO analysis. 
Table A.3-1

Samples Collected at CAS 01-25-01, AST

\begin{tabular}{|c|c|c|c|c|c|}
\hline $\begin{array}{l}\text { Sample } \\
\text { Location }\end{array}$ & $\begin{array}{l}\text { Sample } \\
\text { Number }\end{array}$ & $\begin{array}{c}\text { Depth } \\
\text { (ft bgs) }\end{array}$ & $\begin{array}{l}\text { Sample } \\
\text { Matrix }\end{array}$ & Purpose & Analyses \\
\hline \multirow{2}{*}{$\mathrm{A} 01$} & 322A001 & $0-0.5$ & Soil & SC & Set 1 , Set 2 \\
\hline & $322 \mathrm{~A} 002$ & $2-3$ & Soil & SC & Set 1 , Set 2 \\
\hline \multirow{6}{*}{ A02 } & $322 \mathrm{~A} 003$ & $0-0.5$ & Soil & SC, MS/MSD & Set 1 , Set 2 \\
\hline & 322A004 & $2-3$ & Soil & SC & Set 2 , Set 3 \\
\hline & $322 \mathrm{~A} 005$ & $2-3$ & Soil & $\begin{array}{c}\text { Field Duplicate of } \\
\text { 322A004 }\end{array}$ & Set 2 , Set 3 \\
\hline & $322 \mathrm{~A} 009$ & $4-5$ & Soil & SC & TPH-DRO \\
\hline & $322 \mathrm{~A} 010$ & $6-7$ & Soil & SC & TPH-DRO \\
\hline & $322 \mathrm{~A} 011$ & $9-10$ & Soil & SC & TPH-DRO \\
\hline \multirow{5}{*}{$\mathrm{A} 04$} & $322 \mathrm{~A} 008$ & $0-0.5$ & Soil & SC, MS/MSD & TPH-DRO \\
\hline & $322 \mathrm{~A} 012$ & $2-3$ & Soil & SC & TPH-DRO \\
\hline & $322 \mathrm{~A} 013$ & $4-5$ & Soil & SC & TPH-DRO \\
\hline & 322A014 & $7-8$ & Soil & SC & TPH-DRO \\
\hline & $322 \mathrm{~A} 015$ & $9-10$ & Soil & SC & TPH-DRO \\
\hline \multirow{5}{*}{ A05 } & $322 \mathrm{~A} 016$ & $0-0.5$ & Soil & SC & TPH-DRO \\
\hline & $322 \mathrm{~A} 017$ & $2-3$ & Soil & SC & TPH-DRO \\
\hline & $322 \mathrm{~A} 018$ & $4-5$ & Soil & SC & TPH-DRO \\
\hline & $322 \mathrm{~A} 019$ & $7-8$ & Soil & SC & TPH-DRO \\
\hline & $322 \mathrm{~A} 020$ & $9-10$ & Soil & SC & TPH-DRO \\
\hline \multirow{4}{*}{ NA } & $322 \mathrm{~A} 301$ & NA & Water & Trip Blank & Total VOCs \\
\hline & $322 A 302$ & NA & Water & Field Blank & Set 1 , Set 2 \\
\hline & $322 \mathrm{~A} 303$ & NA & Water & $\begin{array}{c}\text { Equipment } \\
\text { Rinsate Blank }\end{array}$ & TPH-DRO \\
\hline & $322 A 304$ & NA & Water & Field Blank & TPH-DRO \\
\hline
\end{tabular}

No samples were collected from sample location designation A03.

Set 1 = Total VOCs, Total SVOCs, Total RCRA Metals, Total Beryllium, PCBs, Gamma Spectroscopy

Set $2=$ TPH-GRO, TPH-DRO

Set 3 = Total VOCs, Total SVOCs, Total RCRA Metals, Total Beryllium, PCBs

$\mathrm{ft}$ bgs $=$ feet below ground surface

$\mathrm{SC}=$ Site characterization

MS/MSD = Matrix spike/matrix spike duplicate

$\mathrm{NA}=$ Not applicable 


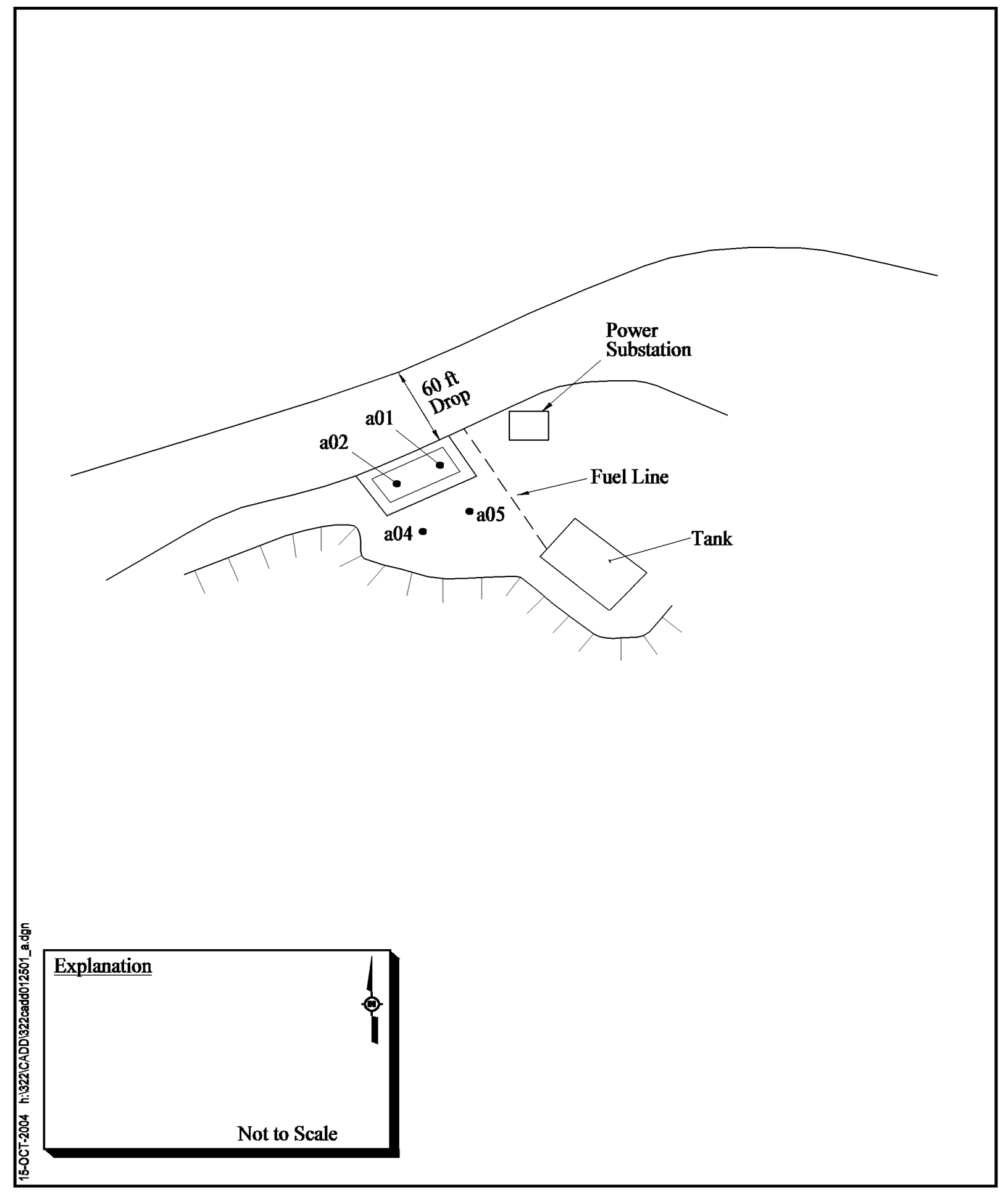

Figure A.3-1

Sample Location Map, CAS 01-25-01, AST Berm 


\section{A.3.2 Investigation Results}

The following sections provide descriptions of the CAS-specific activities conducted to complete investigation activities as outlined in the CAIP. Investigation activities included, visual inspection of the CAS, field screening, and soil and liquid sampling and analysis.

\section{A.3.2.1 Radiological Survey Results}

A radiological walk-over survey was performed at CAS 01-25-01 in April 2004. The survey was performed to determine if radiological contamination is present in surficial soil at CAS 01-25-01 at concentrations statistically greater than surface soil from undisturbed background locations. The results were plotted on a color-coded contour map (Figure A.3-2).

Measurements of the gamma radiation emission rate for surface soil were taken with a TSA Systems Model PRM-470B handheld plastic scintillator over an area of approximately 1,386 square feet $\left(\mathrm{ft}^{2}\right)$. A total of 370 data points were recorded at this site with a mean gamma radiation emission rate of 138 counts per second versus the mean undisturbed background radiation emission rate of 154 counts per second. The maximum gamma radiation emission rate was 175 counts per second. This rate is approximately 1.1 times the mean undisturbed background gamma emission rate (Alderson, 2004).

\section{A.3.2.2 Sampling}

No obvious release of contaminants was observed during the visual inspection of the site surface.

Decision I sampling activities included the collection of two surface and shallow subsurface soil samples from western and eastern ends of the berm where the fuel input and output locations were believed to have been located. Visual examination of the extracted samples indicated the presence of petroleum hydrocarbons adhering to the subsurface material. Laboratory analyses indicated the presence of high level of TPH-DRO (i.e., above the PAL) at both sample locations at both depths collected. Additional soil sampling at increased depths was attempted by hand collection; however, refusal was met at approximately $3 \mathrm{ft} \mathrm{bgs,} \mathrm{and} \mathrm{a} \mathrm{backhoe} \mathrm{was} \mathrm{brought} \mathrm{in} \mathrm{to} \mathrm{collect} \mathrm{samples.} \mathrm{No} \mathrm{other}$ COPCs were identified. 


\section{CAU 322 CAS 01-25-01}

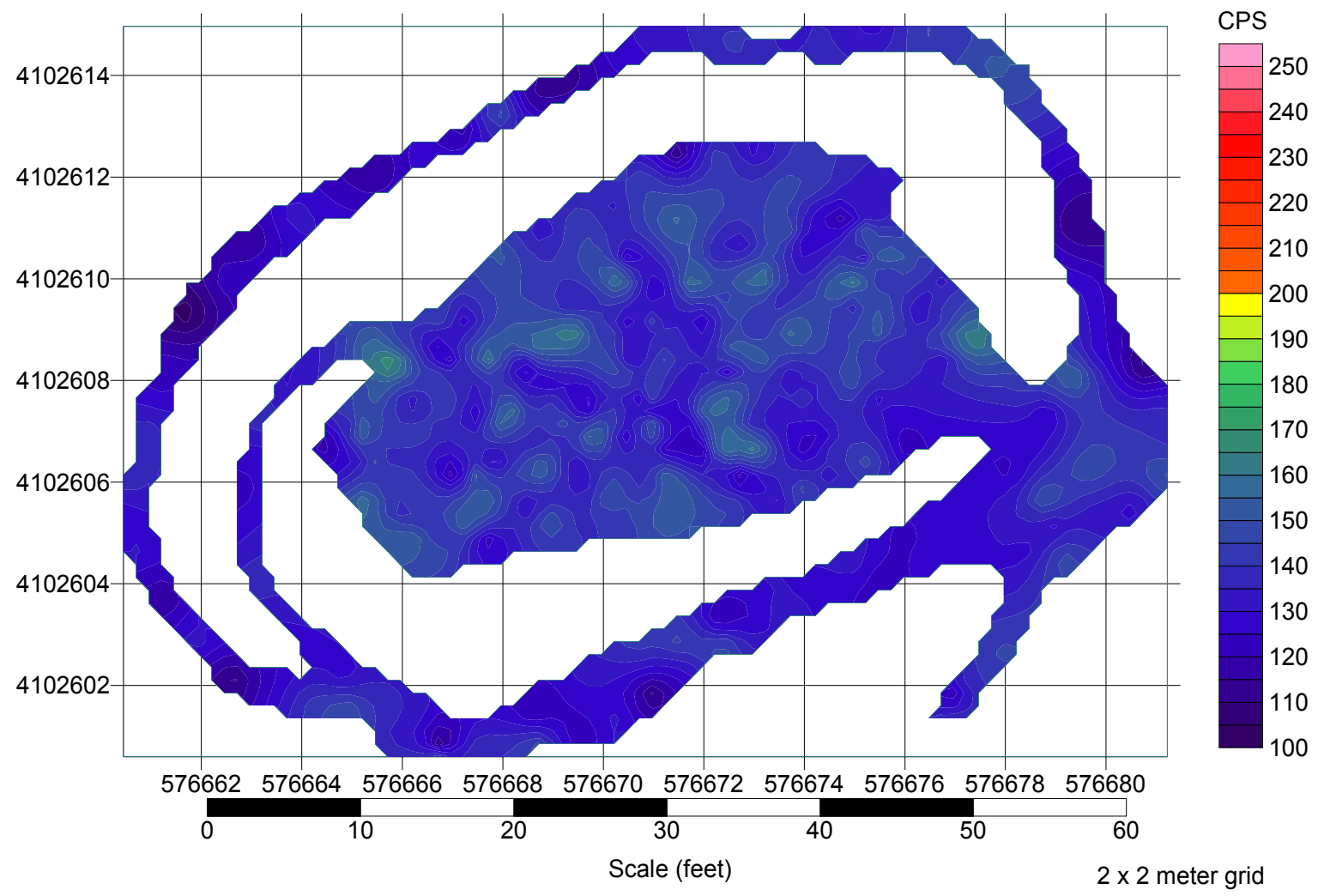

Average Background In Counts Per Second (CPS) 154

Confidence Level That Observed Count Rate Exceeds Background

$68 \% 169$ CPS

$95.4 \% \quad 179$ CPS

$99.7 \% \quad 195$ CPS

$99.9 \% \quad 200$ CPS
Coordinates in UTM 11 North NAD 1927 (WESTERN), meters

Figure A.3-2

Radiological Survey Map for CAS 01-25-01, AST Berm 
Decision II sampling activities included the collection of additional subsurface samples at the location within the berm with the highest levels of TPH-DRO contamination (i.e., location A02). This coincides with the end of the AST where fuel was added, (i.e., the west end of the berm). This location was excavated to the depth determined to be practical based on the berm's physical location and for safety considerations (approximately $10 \mathrm{ft} \mathrm{bgs).}$

Samples were collected as outlined in the CAU 322 CAIP (NNSA/NSO, 2003) and submitted for laboratory analysis.

\section{A.3.2.3 Field Screening}

Soil samples were field screened for VOCs, TPH, and alpha and beta/gamma radiation. The FSRs were compared to FSLs to guide subsequent sampling decisions, with the exception of the samples collected from within the berm, where practical and safety constraints limited the depth of sample collection. The VOC headspace and alpha and beta/gamma radiation FSLs were not exceeded during sampling activities. The TPH FSRs indicated that the deepest sample collected from location A02 within the berm was still above the FSL for TPH-DRO.

\section{A.3.2.4 Sample Analysis}

Investigation samples were analyzed for the CAIP-specified COPCs which included total VOCs, total SVOCs, TPH (DRO/GRO), total RCRA metals and beryllium, and PCBs. The analytical parameters and laboratory methods used to analyze the investigation samples are listed in Table A.2-2. Table A.3-1 lists the sample-specific analytical suite for CAS 01-25-01.

\section{A.3.2.5 Analytes Detected Above Minimum Reporting Limits}

Analytical results from the soil samples with concentrations exceeding MRLs or MDCs are summarized in the following sections. These results are compared to PALs and are a subset of the results that exceed MRLs or MDCs. Results greater than PALs are identified by bold text in the analytical tables. A portion of the analytical results for this CAS were rejected during validation; however, these rejected data did not adversely impact closure decisions as discussed in Appendix B, Section B.1.4. 


\section{A.3.2.5.1 Total VOCs}

Total VOC analytical results for soil samples collected at CAS 01-25-01, which were detected above MRLs, are presented in Table A.3-2. No VOCs were detected in soil samples above PALs.

Table A.3-2

Soil Sample Results for Total VOCs Detected Above Minimum Reporting Limits at CAS 01-25-01, AST

\begin{tabular}{|c|c|c|c|c|c|c|}
\hline \multirow{2}{*}{$\begin{array}{c}\text { Sample } \\
\text { Location }\end{array}$} & \multirow{2}{*}{$\begin{array}{c}\text { Sample } \\
\text { Number }\end{array}$} & \multirow{2}{*}{$\begin{array}{c}\text { Depth } \\
\text { (ft bgs) }\end{array}$} & \multicolumn{4}{|c|}{ Contaminants of Potential Concern $(\mu \mathrm{g} / \mathrm{kg})$} \\
\cline { 5 - 8 } & & & $\mathbf{1 , 3 , 5 - T r i m e t h y l b e n z e n e}$ & Acetone & P-Isopropyltoluene & Tetrachloroethene \\
\hline \multicolumn{2}{|c|}{ Preliminary Action Levels } \\
\end{tabular}

a'Based on U.S. Environmental Protection Agency, Region 9 Preliminary Remediation Goals (PRGs) (EPA, 2002)

$\mathrm{ft}$ bgs $=$ Feet below ground surface

$\mu \mathrm{g} / \mathrm{kg}=$ Micrograms per kilogram

\section{A.3.2.5.2 Total SVOCs}

Total SVOC analytical results for soil samples collected at CAS 01-25-01 were not detected above the MRLs or the PALs.

\section{A.3.2.5.3 Total RCRA Metals and Beryllium}

Total RCRA metals and beryllium analytical results for soil samples collected at CAS 01-25-01, which were detected above MRLs, are presented in Table A.3-3. No metals were detected in soil samples above PALs.

\section{A.3.2.5.4 PCBs}

Analytical results for PCBs in soil samples collected at CAS 01-25-01 did not exceed the MRLs or PALs. 
Table A.3-3

Soil Sample Results for Metals Detected

Above Minimum Reporting Limits at CAS 01-25-01, AST

\begin{tabular}{|c|c|c|c|c|c|c|c|c|}
\hline \multirow{2}{*}{$\begin{array}{l}\text { Sample } \\
\text { Location }\end{array}$} & \multirow{2}{*}{$\begin{array}{l}\text { Sample } \\
\text { Number }\end{array}$} & \multirow{2}{*}{$\begin{array}{c}\text { Depth } \\
\text { (ft bgs) }\end{array}$} & \multicolumn{6}{|c|}{ Contaminants of Potential Concern (mg/kg) } \\
\hline & & & Arsenic $^{a}$ & Barium $^{b}$ & Beryllium $^{b}$ & Chromium $^{b}$ & Lead $^{b}$ & Selenium $^{b}$ \\
\hline \multicolumn{3}{|c|}{ Preliminary Action Levels } & 23 & 67,000 & 1,900 & 450 & 750 & 5,100 \\
\hline \multirow{2}{*}{ A01 } & $\overline{322 \mathrm{~A} 001}$ & $\overline{0-0.5}$ & 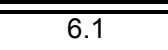 & $\overline{2230(\mathrm{~J})}$ & 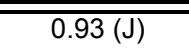 & $\overline{24}$ & 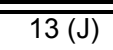 & $\overline{0.98}$ \\
\hline & 322A002 & $2-3$ & 6.6 & $250(\mathrm{~J})$ & $1.1(\mathrm{~J})$ & 13 & $12(\mathrm{~J})$ & $0.98(\mathrm{~J})$ \\
\hline \multirow{3}{*}{ A02 } & $322 \mathrm{~A} 003$ & $0-0.5$ & 4.9 & $180(\mathrm{~J})$ & - & 9.4 & $9.6(\mathrm{~J})$ & -- \\
\hline & $322 A 004$ & $2-3$ & 11 & $320(\mathrm{~J})$ & $0.74(\mathrm{~J})$ & 10 & $9(\mathrm{~J})$ & -- \\
\hline & $322 \mathrm{~A} 005$ & $2-3$ & 11 & $260(\mathrm{~J})$ & $0.77(\mathrm{~J})$ & 11 & $8.7(\mathrm{~J})$ & $1.1(\mathrm{~J})$ \\
\hline
\end{tabular}

${ }^{a}$ Based on the background concentrations for metals. Background is considered the mean plus two times the standard deviation for sediment samples collected by the Nevada Bureau of Mines and Geology throughout the Nevada Test and Training Range (NBMG, 1998; Moore, 1999).

based on U.S. Environmental Protection Agency, Region 9 Preliminary Remediation Goals (PRGs) (EPA, 2002).

$\mathrm{ft}$ bgs $=$ Feet below ground surface

$\mathrm{mg} / \mathrm{kg}=$ Milligrams per kilogram

$\mathrm{J}=$ Estimated value

$--=$ Not detected above minimum reporting limits

\section{A.3.2.5.5 TPH-GRO and TPH-DRO}

Analytical results for TPH-GRO and TPH-DRO in soil samples collected at CAS 01-25-01 that exceeded the MRLs are presented in Table A.3-4. Samples collected at both Decision I locations indicated TPH-DRO concentrations above the PALs. Location A02 was chosen for further sampling to define the depth of contamination. Samples collected from location A02 up to $10 \mathrm{ft}$ bgs all contained TPH-DRO above the PAL (highest concentration is $7,000 \mathrm{mg} / \mathrm{kg}$ ). The concentrations of TPH-DRO decreased with increasing depth (see Figure A.3-3). Sampling was halted at approximately $10 \mathrm{ft}$ bgs due to both physical and safety considerations.

\section{A.3.2.5.6 Gamma-Emitting Radionuclides}

Analytical results for gamma-emitting radionuclides in soil samples collected at CAS 01-25-01, that exceeded MDCs are presented in Table A.3-5. No gamma-emitting radionuclides were detected above PALs. 
Table A.3-4

Soil Sample Results for TPH (DRO and GRO) Detected Above Minimum Reporting Limits at CAS 01-25-01, AST

\begin{tabular}{|c|c|c|c|c|}
\hline \multirow{2}{*}{$\begin{array}{l}\text { Sample } \\
\text { Location }\end{array}$} & \multirow{2}{*}{$\begin{array}{c}\text { Sample } \\
\text { Number }\end{array}$} & \multirow{2}{*}{$\begin{array}{l}\text { Depth } \\
\text { (ft bgs) }\end{array}$} & \multicolumn{2}{|c|}{ Contaminants of Potential Concern (mg/kg) } \\
\hline & & & Gasoline Range Organics & Diesel Range Organics \\
\hline \multicolumn{3}{|c|}{ Preliminary Action Levels ${ }^{a}$} & 100 & 100 \\
\hline \multirow{2}{*}{$\mathrm{A} 01$} & 322A001 & $0-0.5$ & $\overline{---}$ & $\overline{2,900(\mathrm{~J})}$ \\
\hline & $322 \mathrm{~A} 002$ & $2-3$ & -- & 480 (D) \\
\hline \multirow{6}{*}{ A02 } & $322 \mathrm{~A} 003$ & $0-0.5$ & -- & $5,900(\mathrm{~J})$ \\
\hline & $322 \mathrm{~A} 004$ & $2-3$ & $10(\mathrm{H})$ & $7,000(\mathrm{~J})$ \\
\hline & $322 \mathrm{~A} 005$ & $2-3$ & $15(\mathrm{H})$ & $6,900(\mathrm{D})$ \\
\hline & $322 A 009$ & $4-5$ & -- & $6,700(\mathrm{D})$ \\
\hline & $322 \mathrm{~A} 010$ & $6-7$ & -- & $1,100(D)$ \\
\hline & $322 \mathrm{~A} 011$ & $9-10$ & -- & $140(\mathrm{D})$ \\
\hline
\end{tabular}

${ }^{a}$ Based on Nevada Administrative Code; Contamination of soil: Establishment of action levels (NAC, 2002)

$\mathrm{ft}$ bgs $=$ Feet below ground surface

$\mathrm{mg} / \mathrm{kg}=$ Milligrams per kilogram

$\mathrm{D}=\mathrm{A}$ pattern resembling diesel was detected in the samples

$\mathrm{H}=$ The fuel pattern was in the heavier end of the retention time window for the analyte of interest

$\mathrm{J}=$ Estimated value; qualifier added to laboratory data, record accepted; surrogates diluted out

\section{A.3.2.6 Contaminants of Concern}

Based on the analytical results, the only COC identified was TPH-DRO within the AST berm.

\section{A.3.3 Nature and Extent of Contamination}

Analytical results from within the berm indicate TPH-DRO is present at concentrations above the PAL. Because sampling had to be halted at approximately $10 \mathrm{ft}$ bgs due to safety considerations, a "clean" vertical sample was not obtained. The TPH-DRO concentrations for the five samples collected at location A01 were applied to a model in order to estimate the depth beneath the berm at which the TPH-DRO concentration fell below the PAL. Analytical results suggested that the adsorption of TPH-DRO with depth in the soil column is not a linear phenomenon. Application of a logarithmic adsorption model versus soil depth for the laboratory analytical results provides a linear correlation (correlation coefficient of -0.966 [Figure A.3-4]). Applying a conservative value of $50 \mathrm{ppm}$ TPH-DRO (the PAL is $100 \mathrm{ppm}$ ) to the model resulted in a corresponding depth of $11.7 \mathrm{ft}$ bgs (rounded off to $12 \mathrm{ft}$ bgs, again as a conservative measure). 


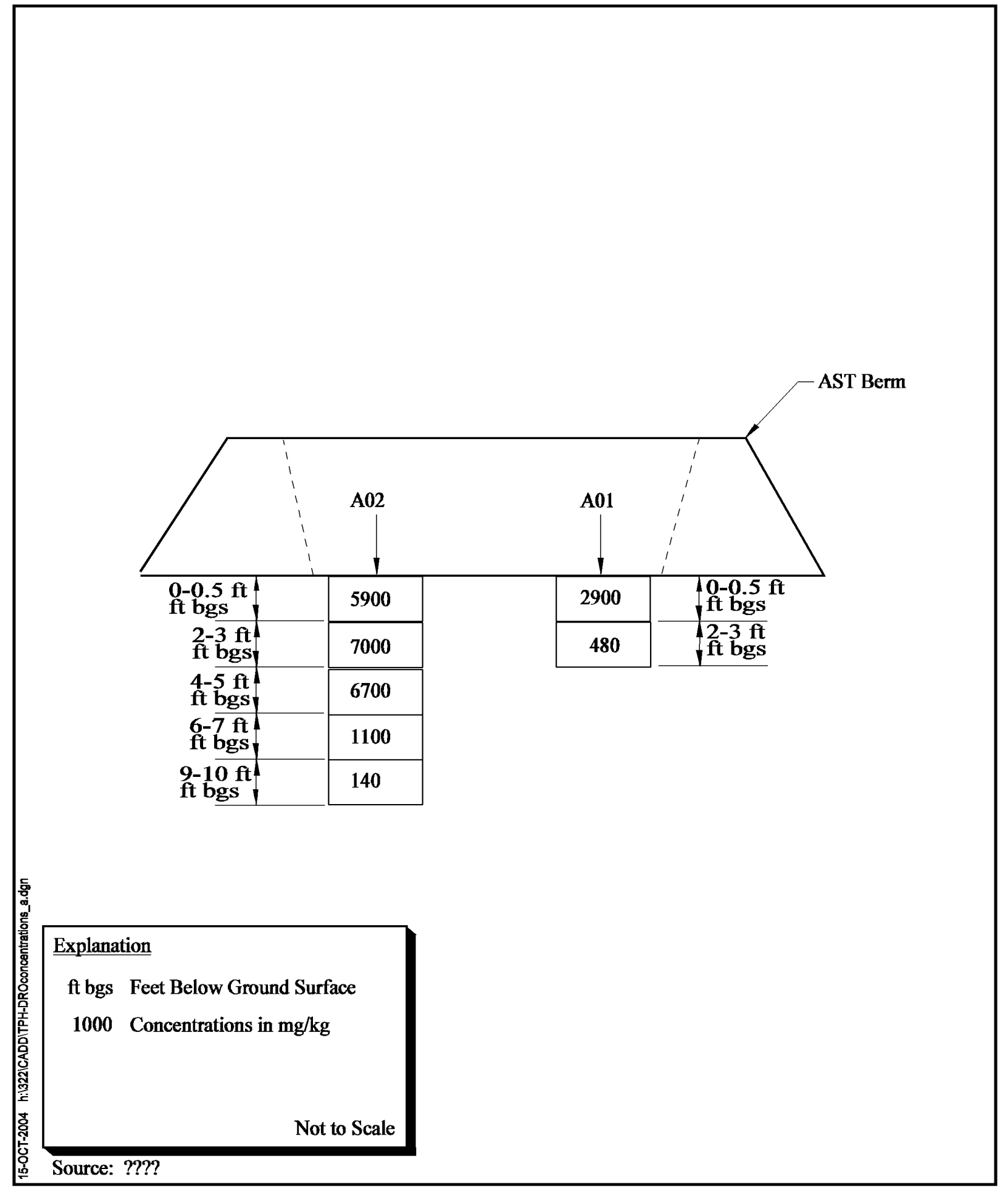

Figure A.3-3

Vertical Profile of TPH-DRO Concentrations for CAS 01-25-01, AST Berm 
Table A.3-5

Soil Sample Results for Gamma-Emitting Radionuclides Detected Above Minimum Detectable Concentrations at CAS 01-25-01, AST

\begin{tabular}{||c|c|c|c|c|c|c||}
\hline \multirow{2}{*}{$\begin{array}{c}\text { Sample } \\
\text { Location }\end{array}$} & \multirow{2}{*}{$\begin{array}{c}\text { Sample } \\
\text { Number }\end{array}$} & \multirow{2}{*}{$\begin{array}{c}\text { Depth } \\
(\mathrm{ft} \text { bgs) }\end{array}$} & \multicolumn{4}{|c|}{ Contaminants of Potential Concern (pCi/g) } \\
\cline { 4 - 7 } & & Actinium-228 & Bismuth-214 & Lead-212 & Lead-214 \\
\hline \multicolumn{3}{|c|}{ Preliminary Action Levels ${ }^{\mathrm{a}}$} & $\mathbf{5}$ & $\mathbf{5}$ & $\mathbf{5}$ & $\mathbf{5}$ \\
\hline \multicolumn{3}{|c|}{ Depth bgs (cm) } & $<15$ & $<15$ & $<15$ & $<15$ \\
\hline \hline $\mathrm{A} 01$ & $322 \mathrm{~A} 001$ & $0-0.5$ & $1.93(\mathrm{G})$ & $0.85(\mathrm{G})$ & $1.66(\mathrm{~J})$ & $1.04(\mathrm{~J})$ \\
\hline $\mathrm{A} 02$ & $322 \mathrm{~A} 003$ & $0-0.5$ & $2.14(\mathrm{G})$ & $1.19(\mathrm{G})$ & $1.32(\mathrm{~J})$ & $1.03(\mathrm{~J})$ \\
\hline
\end{tabular}

aBased on the generic guidelines for residual concentrations of radium-226, radium-228, thorium-230, and thorium-232 as found in Chapter IV of DOE order 5400.5 Change 2 Radiation Protection of the Public and Environment. The PAL for these isotopes is specified as 5 picocuries per gram $(\mathrm{pCi} / \mathrm{g})$ averaged over the first 15 centimeters of soil and $15 \mathrm{pCi} / \mathrm{g}$ for deeper soils. For purposes of this document, 15 centimeters is assumed to be equivalent to $0.5 \mathrm{ft}$ ( 6 inches) (DOE, 1993).

$\mathrm{ft}$ bgs $=$ Feet below ground surface

$\mathrm{cm}=$ Centimeter

$\mathrm{pCi} / \mathrm{g}=$ Picocuries per gram

$<=$ Less than

$\mathrm{G}=$ Sample density differs by more than 15 percent of laboratory control sample density.

$\mathrm{J}=$ Estimated value. Qualifier added to laboratory data; record accepted. Sample does not meet counting geometry requirements.

Step-out samples located outside the berm at sample locations A04 and A05 indicated no TPH-DRO presence. Due to the physical constraints of the site, step-out samples were collected at only two locations. The TPH-DRO contamination was determined to be within the confines of the berm.

There is an estimated $267 \mathrm{yd}^{3}$ of soil contaminated with TPH-DRO above the PAL at this CAS.

\section{A.3.4 Revised Conceptual Site Model}

While the CSM is satisfied for this CAS, the magnitude of the TPH-DRO contamination is significantly greater than originally thought. It was originally believed that no TPH-DRO contamination existed at this site. However, once the gravel covering of the berm floor was moved aside (a gravel thickness of 2 to $3 \mathrm{in}$.) and the first penetration into the underlying soil was made, it was clear TPH-DRO contamination existed. During the Decision I sampling, refusal was encountered at the 2 to $3 \mathrm{ft}$ bgs depth at both sampling locations, requiring the use of a backhoe and the planning for Decision II sampling. The CSM indicated the contamination that might arise from TPH-DRO spillage/overfilling at this CAS would migrate both laterally and vertically. The Decision 
A TPH-DRO concentration of $50 \mathrm{mg} / \mathrm{kg}$ was used as a conservative estimate of "depth to clean" The "depth to clean" was determined to be $11.7 \mathrm{ft}$ bgs (rounded off to $12 \mathrm{ft} \mathrm{bgs}$ )

$\begin{array}{rr}\text { Log (conc) } & \text { Depth } \\ 3.85 & 3 \\ 3.82 & 5 \\ 3.04 & 7 \\ 2.15 & 10\end{array}$

Corr coeff $=\quad-0.966$

$r$ squared $=0.9320$

\section{Semi-Log Graph}

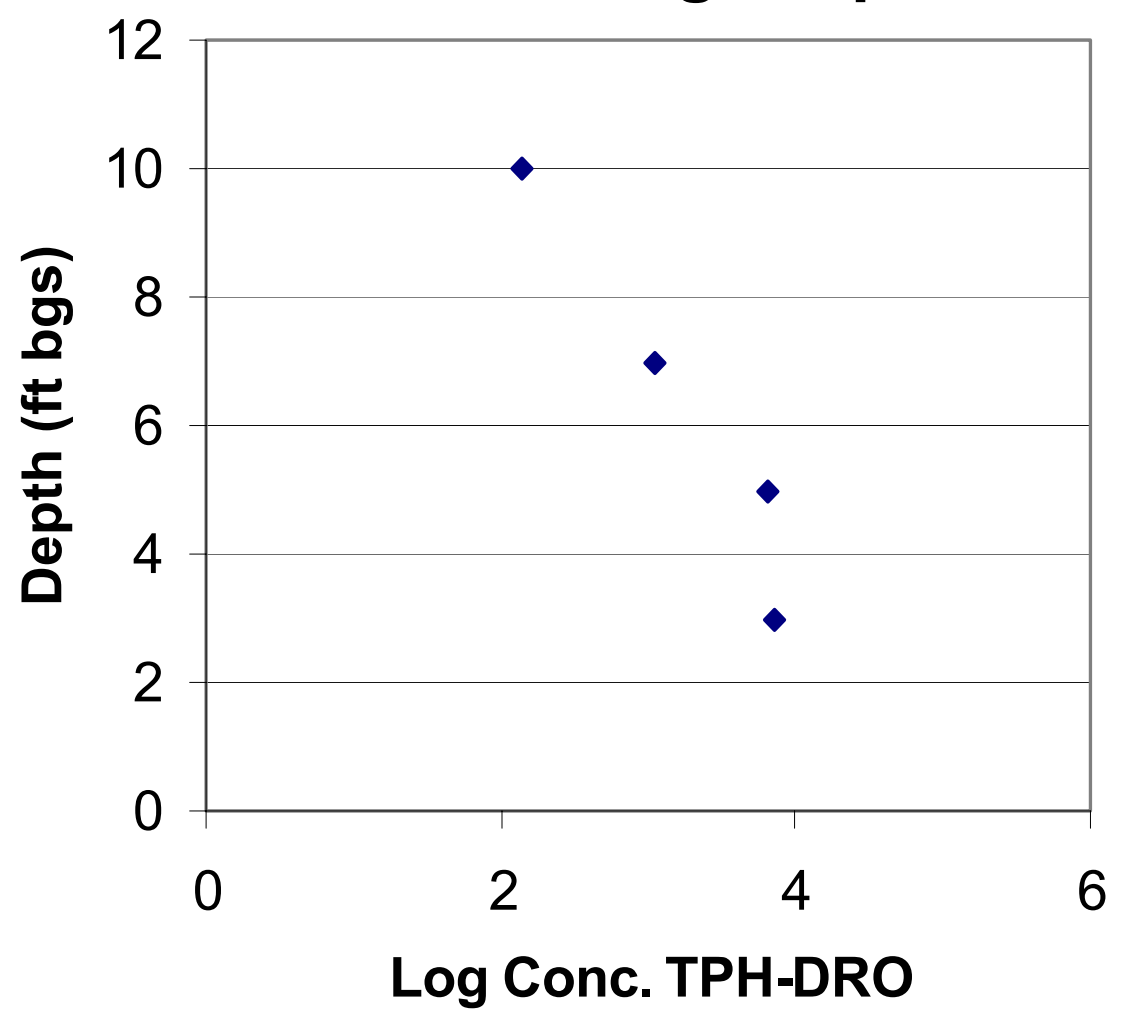

Figure A.3-4

TPH-DRO Data Regression Plot for CAS 01-25-01, AST Berm 
II sampling demonstrates vertical movement of TPH-DRO, and the step-out samples indicate that any lateral movement does not extend beyond the bounds of the berm. 


\section{A.4.0 CAS 03-25-03, AST Release and Mud Plant}

Corrective Action Site 03-25-03 is located in Area 3 of the NTS. The CAS is divided into two "Areas" (A and B). Area A is in the western portion of the CAS and consists of a J-shaped berm which once housed a diesel fuel AST. The Area B portion of the CAS is located along the eastern side of the Area 3 Mud Plant, and is bounded to the west by the Mud Plant footprint, to the north by the Mud Disposal Crater (CAU 34) and to the east by the Mud Plant Pond (CAU 34).

Investigation activities at CAS 03-25-03 Area A included characterization sampling of selected locations to identify the presence and concentrations of COPCs, especially TPH-DRO which was historically documented to have spilled onto the surface at the AST and filling pump, and leaked from the piping from the AST. Based on information available at the time the CAIP was written, much of the spilled fuel was remediated, but it was reported that some remained at depth between 10 to $15 \mathrm{ft}$ bgs.

Investigation activities at Area B include collection of data to complement the data obtained from CAU 34 conducted two years earlier. In the course of investigation activities for CAU 34, several locations and various depth were found to be contaminated with TPH-DRO. However, none of the TPH-DRO contamination was removed and the CAU 322 CAI was to augment the information from CAU 34 to identify any potential sources and the extent of the contamination.

The CSM for CAS 03-25-03 included potential soil contamination originating from COPCs associated with a leaking AST (Area A) and from potential unknown point sources and/or general activity associated with Mud Plant operations (Area B). Radioactive contamination resulting from safety experiments and atmospheric nuclear testing is not considered part of the CAS.

\section{A.4.1 Corrective Action Investigation}

A visual assessment of both areas (A and B) was made to identify any biasing factors such as staining and/or sheens that might indicate contamination to the soil. No biasing factors were noted at the site surface. 
A total of 75 soil samples and 1 swipe sample were collected at CAS 03-25-03. The swipe sample was collected in Area B when a concrete pad was discovered under approximately 2 in. of soil that was removed because analytical results indicated the location was over the PAL for plutonium-239. The concrete pad was swipe sampled, and three step-out soil samples were collected around the hot spot. Thirty-six samples were collected from Area A of CAS 03-25-03 and thirty-nine samples were collected from Area B. These samples were analyzed for the parameters listed in Table A.4-1. Sample locations for Area A are shown on Figure A.4-1 and sample locations for Area B are shown in Figure A.4-2.

The CAI for CAS 03-25-03 Area B also used sample analytical results for TPH-DRO generated during the CAI for CAU 34. Table A.4-2 includes the samples collected during the CAI for CAU 34 that provided information used for the CAS 03-25-03 Area B investigation. These locations are also included on Figure A.4-2.

\section{A.4.1.1 Deviations}

There were no deviations to the CAIP requirements at this CAS. The investigation and sampling at CAS 03-25-03 is considered sufficient to meet the DQOs.

\section{A.4.2 Investigation Results}

The following sections provide descriptions of the CAS-specific activities conducted to complete investigation activities as outlined in the CAIP. Investigation activities included visual inspection of the CAS, collection of soil samples, collection of a swipe sample from the location of a localized area of elevated radiological activity, and sample analysis.

\section{A.4.2.1 Radiological Survey Results}

A radiological walk-over survey was performed at CAS 03-25-03 in April 2004. The survey was performed to determine if radiological contamination is present in surficial soil at CAS 03-25-03 at concentrations statistically greater than surficial soil from undisturbed background locations. The results were plotted on a color-coded contour map (Figure A.4-3). 
Table A.4-1

Samples Collected at CAS 03-25-03, AST and Mud Plant (Page 1 of 4 )

\begin{tabular}{|c|c|c|c|c|c|c|}
\hline $\begin{array}{l}\text { Sample } \\
\text { Location }\end{array}$ & Area & $\begin{array}{l}\text { Sample } \\
\text { Number }\end{array}$ & $\begin{array}{c}\text { Depth } \\
\text { (ft bgs) }\end{array}$ & $\begin{array}{l}\text { Sample } \\
\text { Matrix }\end{array}$ & Purpose & Analyses \\
\hline \multirow{6}{*}{ B01 } & \multirow{6}{*}{ A } & 322B007 & $0-0.5$ & Soil & SC & Sets $1,2,3$, and 4 \\
\hline & & 322B038 & $2-3$ & Soil & SC & Sets 1 and 3 \\
\hline & & 322B069A & $4.5-5.5$ & Soil & Confirmation & TPH-DRO \\
\hline & & 322B070A & $4.5-5.5$ & Soil & Confirmation & TPH-DRO \\
\hline & & 322B071 & $4.5-5.5$ & Soil & Confirmation & TPH-DRO \\
\hline & & 322B039 & $19-20$ & Soil & SC & Sets 1 and 3 \\
\hline \multirow{3}{*}{ B02 } & \multirow{3}{*}{ A } & 322B008 & $0-0.5$ & Soil & SC & Sets $1,2,3$ and 4 \\
\hline & & 322B036 & $2-3$ & Soil & SC & Sets 1 and 3 \\
\hline & & 322B037 & $19-20$ & Soil & SC & Sets 1 and 2 \\
\hline \multirow{4}{*}{ B03 } & \multirow{4}{*}{ A } & 322B009 & $0-0.5$ & Soil & SC & Sets $1,2,3$ and 4 \\
\hline & & 322B033 & $2-3$ & Soil & SC & Sets 1 and 3 \\
\hline & & 322B034 & $2-3$ & Soil & $\begin{array}{l}\text { Field Duplicate of } \\
\text { 322B033 }\end{array}$ & Sets 1 and 3 \\
\hline & & 322B035 & $19-20$ & Soil & SC & Sets 1 and 3 \\
\hline \multirow{4}{*}{ B04 } & \multirow{4}{*}{ A } & 322B010 & $0-0.5$ & Soil & SC & Sets $1,2,3$ and 4 \\
\hline & & 322B028 & $2-3$ & Soil & SC & Sets 1 and 3 \\
\hline & & 322B032 & $19-20$ & Soil & SC, MS/MSD & Sets 1 and 3 \\
\hline & & 322B068A & $0-0.5$ & Soil & Confirmation & TPH-DRO \\
\hline \multirow{6}{*}{ B05 } & \multirow{6}{*}{ A } & 322B011 & $0-0.5$ & Soil & SC & Sets $1,2,3$ and 4 \\
\hline & & 322B023 & $3-4$ & Soil & SC & Sets 1 and 3 \\
\hline & & 322B024 & $7-8$ & Soil & SC & Sets 1 and 3 \\
\hline & & 322B025 & $11-12$ & Soil & SC & Sets 1 and 3 \\
\hline & & 322B026 & $15-16$ & Soil & SC & Sets 1 and 3 \\
\hline & & 322B027 & $19-20$ & Soil & SC & Sets 1 and 3 \\
\hline \multirow{4}{*}{ B06 } & \multirow{4}{*}{ A } & 322B001 & $0-0.5$ & Soil & SC & Sets $1,2,3$ and 4 \\
\hline & & 322B003 & $2-3$ & Soil & SC & $\begin{array}{c}\text { Sets } 1,4 \text {, and } \\
\text { TPH-GRO }\end{array}$ \\
\hline & & 322B004 & $6-7$ & Soil & SC & $\begin{array}{c}\text { Sets } 1,4 \text {, and } \\
\text { TPH-GRO }\end{array}$ \\
\hline & & 322B021 & $15-16$ & Soil & SC & Sets 1 and 3 \\
\hline
\end{tabular}


Table A.4-1

Samples Collected at CAS 03-25-03, AST and Mud Plant (Page 2 of 4 )

\begin{tabular}{|c|c|c|c|c|c|c|}
\hline $\begin{array}{l}\text { Sample } \\
\text { Location }\end{array}$ & Area & $\begin{array}{l}\text { Sample } \\
\text { Number }\end{array}$ & $\begin{array}{l}\text { Depth } \\
\text { (ft bgs) }\end{array}$ & $\begin{array}{l}\text { Sample } \\
\text { Matrix }\end{array}$ & Purpose & Analyses \\
\hline \multirow{4}{*}{ B07 } & \multirow{4}{*}{ A } & 322B002 & $0-0.5$ & Soil & $\mathrm{SC}$ & Sets 1,3 and 4 \\
\hline & & 322B005 & $2-3$ & Soil & SC & Sets 1,3 and 4 \\
\hline & & 322B006 & $5-6$ & Soil & SC & Sets 1,3 and 4 \\
\hline & & 322B022 & $15-16$ & Soil & SC & Sets 1 and 3 \\
\hline \multirow{6}{*}{ B08 } & \multirow{6}{*}{ B } & 322B012 & $0-0.5$ & Soil & SC & Sets $1,2,3$ and 4 \\
\hline & & 322B053 & $2-3$ & Soil & SC & Sets 1 and 3 \\
\hline & & 322B054 & $14-15$ & Soil & SC & Sets 1 and 3 \\
\hline & & 322B055 & $14-15$ & Soil & $\begin{array}{l}\text { Field Duplicate of } \\
\text { 322B054 }\end{array}$ & Sets 1 and 3 \\
\hline & & 322B072 & $4-5$ & Soil & SC & TPH-DRO \\
\hline & & 322B073 & $4-5$ & Soil & $\begin{array}{l}\text { Field Duplicate of } \\
\text { 322B072 }\end{array}$ & TPH-DRO \\
\hline \multirow{3}{*}{ B09 } & \multirow{3}{*}{ B } & 322B013 & $0-0.5$ & Soil & SC & Sets $1,2,3$ and 4 \\
\hline & & 322B051 & $2-3$ & Soil & SC & Sets 1 and 3 \\
\hline & & 322B052 & $14-15$ & Soil & SC, MS/MSD & Sets 1 and 3 \\
\hline B10 & B & 322B014 & $0-0.5$ & Soil & SC, MS/MSD & Sets $1,2,3$ and 4 \\
\hline \multirow{3}{*}{ B11 } & \multirow{3}{*}{ B } & 322B015 & $0-0.5$ & Soil & SC & Sets $1,2,3$ and 4 \\
\hline & & 322B047 & $2-3$ & Soil & SC & Sets 1 and 3 \\
\hline & & 322B048 & $14-15$ & Soil & SC & Sets 1 and 3 \\
\hline \multirow{4}{*}{ B12 } & \multirow{4}{*}{ B } & 322B016 & $0-0.5$ & Soil & SC & Sets $1,2,3$, and 4 \\
\hline & & 322B017 & $0-0.5$ & Soil & $\begin{array}{l}\text { Field Duplicate of } \\
\text { 322B016 }\end{array}$ & Sets $1,2,3$ and 4 \\
\hline & & 322B049 & $2-3$ & Soil & SC & Sets 1 and 3 \\
\hline & & 322B050 & $14-15$ & Soil & SC & Sets 1 and 3 \\
\hline \multirow{3}{*}{ B13 } & \multirow{3}{*}{ B } & 322B018 & $0-0.5$ & Soil & SC & Sets $1,2,3$ and 4 \\
\hline & & 322B040 & $2-3$ & Soil & SC & Sts 1 and 3 \\
\hline & & 322B041 & $14-15$ & Soil & SC & Sets 1 and 3 \\
\hline \multirow{3}{*}{ B14 } & \multirow{3}{*}{ B } & 322B019 & $0-0.5$ & Soil & SC & Sets $1,2,3$ and 4 \\
\hline & & 322B042 & $2-3$ & Soil & SC & Sets 1 and 3 \\
\hline & & 322B043 & $14-15$ & Soil & SC & Sets 1 and 3 \\
\hline
\end{tabular}


Table A.4-1

Samples Collected at CAS 03-25-03, AST and Mud Plant (Page 3 of 4 )

\begin{tabular}{|c|c|c|c|c|c|c|}
\hline $\begin{array}{l}\text { Sample } \\
\text { Location }\end{array}$ & Area & $\begin{array}{l}\text { Sample } \\
\text { Number }\end{array}$ & $\begin{array}{l}\text { Depth } \\
\text { (ft bgs) }\end{array}$ & $\begin{array}{l}\text { Sample } \\
\text { Matrix }\end{array}$ & Purpose & Analyses \\
\hline \multirow{4}{*}{ B15 } & \multirow{4}{*}{$B$} & 322B020 & $0-0.5$ & Soil & SC & Sets $1,2,3$ and 4 \\
\hline & & 322B044 & $2-3$ & Soil & SC & Sets 1 and 3 \\
\hline & & 322B045 & $10-11$ & Soil & SC & Sets 1 and 3 \\
\hline & & 322B046 & $14-15$ & Soil & SC & Sets 1 and 3 \\
\hline \multirow{3}{*}{ B16 } & \multirow{3}{*}{$B$} & 322B059 & $1-2$ & Soil & SC & Sets 1 and 3 \\
\hline & & 322B060 & $15-16$ & Soil & SC & Sets 1 and 3 \\
\hline & & 322B061 & $20-21$ & Soil & SC & Sets 1 and 3 \\
\hline \multirow{2}{*}{ B17 } & \multirow{2}{*}{ B } & 322B062 & $2-3$ & Soil & SC & Sets 1 and 3 \\
\hline & & 322B063 & $7-8$ & Soil & $\mathrm{SC}$ & Sets 1 and 3 \\
\hline \multirow{3}{*}{ B18 } & \multirow{3}{*}{ B } & 322B056 & $15-16$ & Soil & SC & Sets 1 and 3 \\
\hline & & 322B057 & $20-21$ & Soil & SC & Sets 1 and 3 \\
\hline & & 322B058 & $25-26$ & Soil & SC & Sets 1 and 3 \\
\hline \multirow{4}{*}{ B19 } & \multirow{4}{*}{ A } & 322B064 & $0-1$ & Soil & SC, MS/MSD & Sets $1,2,3$ and 4 \\
\hline & & 322B065 & $15-16$ & Soil & SC & Sets 1 and 3 \\
\hline & & 322B066 & $19-20$ & Soil & SC & Sets 1 and 3 \\
\hline & & 322B067 & $19-20$ & Soil & $\begin{array}{l}\text { Field Duplicate of } \\
\text { 322B066 }\end{array}$ & Sets 1 and 3 \\
\hline \multirow{3}{*}{ B20 } & \multirow{3}{*}{$B$} & 322B068 & $2-3$ & Soil & SC & Sets 1 and 3 \\
\hline & & 322B069 & $6-7$ & Soil & $\mathrm{SC}$ & Sets 1 and 3 \\
\hline & & 322B070 & $9-10$ & Soil & SC & Sets 1 and 3 \\
\hline B21 & $B$ & 322B074 & $4-5$ & Soil & SC, MS/MSD & TPH-DRO \\
\hline B22 & B & 322B075 & $4-5$ & Soil & SC & TPH-DRO \\
\hline B23 & $B$ & 322B076 & $0-0.5$ & Soil & SC & Iso-Pu \\
\hline B24 & B & 322B077 & $0-0.5$ & Soil & SC & Iso-Pu \\
\hline B25 & B & 322B078 & $0-0.5$ & Soil & SC & Iso-Pu \\
\hline
\end{tabular}


Table A.4-1

Samples Collected at CAS 03-25-03, AST and Mud Plant

(Page 4 of 4 )

\begin{tabular}{|c|c|c|c|c|c|c|}
\hline $\begin{array}{l}\text { Sample } \\
\text { Location }\end{array}$ & Area & $\begin{array}{l}\text { Sample } \\
\text { Number }\end{array}$ & $\begin{array}{c}\text { Depth } \\
\text { (ft bgs) }\end{array}$ & $\begin{array}{l}\text { Sample } \\
\text { Matrix }\end{array}$ & Purpose & Analyses \\
\hline \multirow{11}{*}{ NA } & \multirow{11}{*}{ NA } & 322B301 & NA & Water & Trip Blank & Total VOCs \\
\hline & & 322B302 & NA & Water & Trip Blank & Total VOCs \\
\hline & & 322B303 & NA & Water & Trip Blank & Total VOCs \\
\hline & & 322B304 & NA & Water & Trip Blank & Total VOCs \\
\hline & & 322B305 & NA & Water & Trip Blank & Total VOCs \\
\hline & & 322B306 & NA & Water & Field Blank & Sets 1,2 , and 3 \\
\hline & & 322B307 & NA & Water & Trip Blank & Total VOCs \\
\hline & & 322B308 & NA & Water & Trip Blank & Total VOCs \\
\hline & & 322B309 & NA & Water & Trip Blank & Total VOCs \\
\hline & & 322B310 & NA & Water & Field Blank & Sets 1,2 , and 3 \\
\hline & & 322B311 & NA & Water & Field Blank & TPH-DRO \\
\hline
\end{tabular}

Set 1 = Total VOCs, Total SVOCs, Total RCRA Metals, PCBs, Total Beryllium

Set 2 = Gamma Spectroscopy

Set $3=$ TPH-GRO, TPH-DRO

Set 4 = Isotopic Uranium, Isotopic Plutonium, Strontium-90

$\mathrm{ft}$ bgs $=$ Feet below ground surface

NA = Not applicable

$\mathrm{SC}=$ Site characterization

$\mathrm{MS} / \mathrm{MSD}=$ Matrix spike/matrix spike duplicate

Measurements of the gamma radiation emission rate for surficial soil were taken with a TSA Systems Model PRM-470B handheld plastic scintillator over an area of approximately $68,512 \mathrm{ft}^{2}$. A total of 5,724 data points were recorded at this site with a mean gamma radiation emission rate of 1,770 counts per second versus the mean undisturbed background radiation emission rate of 1,805 counts per second. The maximum gamma radiation emission rate was 2,241 counts per second. This rate is approximately 1.2 times the mean undisturbed background gamma emission rate (Alderson, 2004).

\section{A.4.2.2 Inspection and Sampling}

No obvious release of contaminants or biasing factors were observed at the surface of either Area A; or Area B during the visual inspection. Decision I sampling included collection of soil samples from 


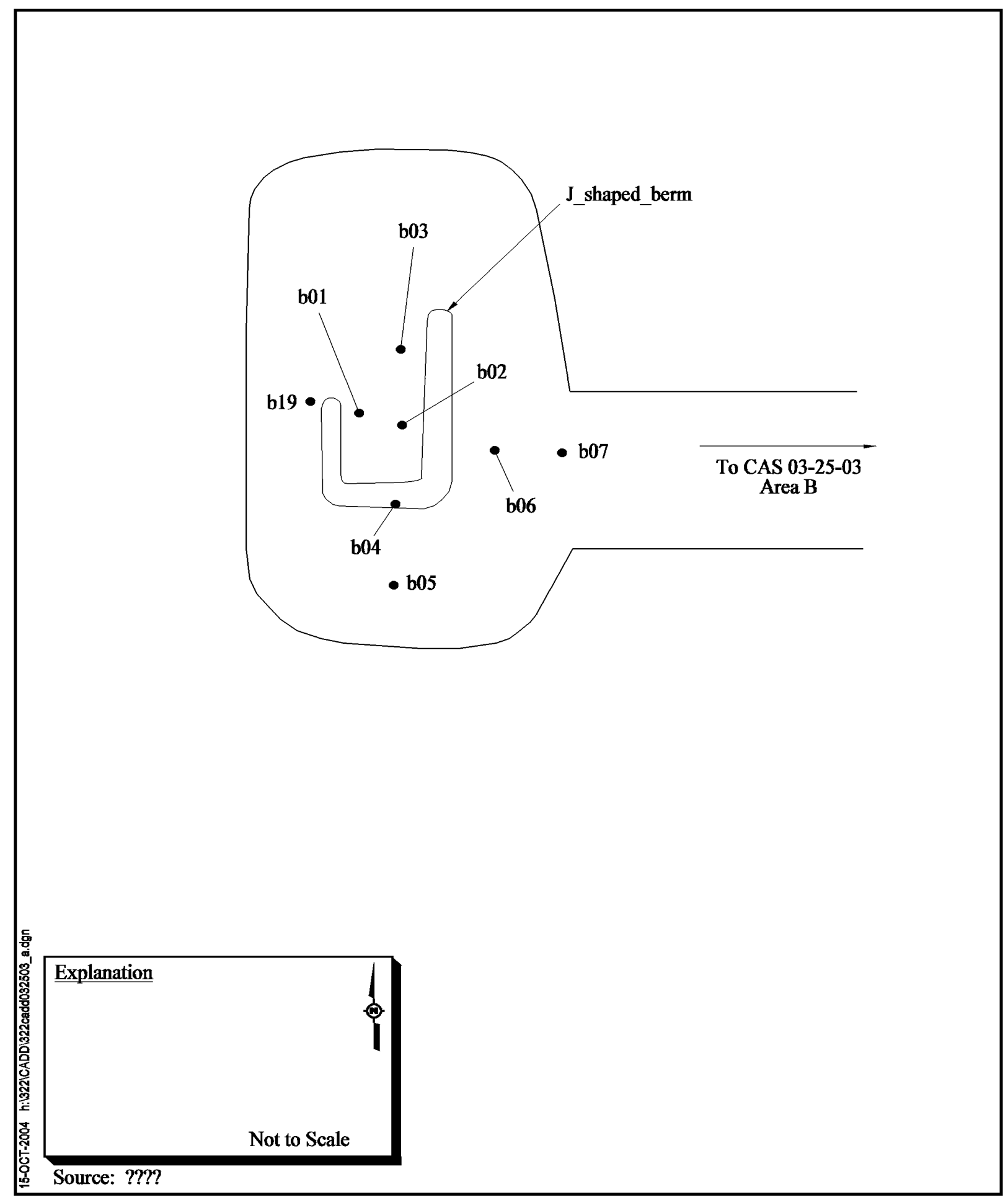

Figure A.4-1

Sample Location Map for CAS 03-25-03, AST Release Area A, AST Berm 


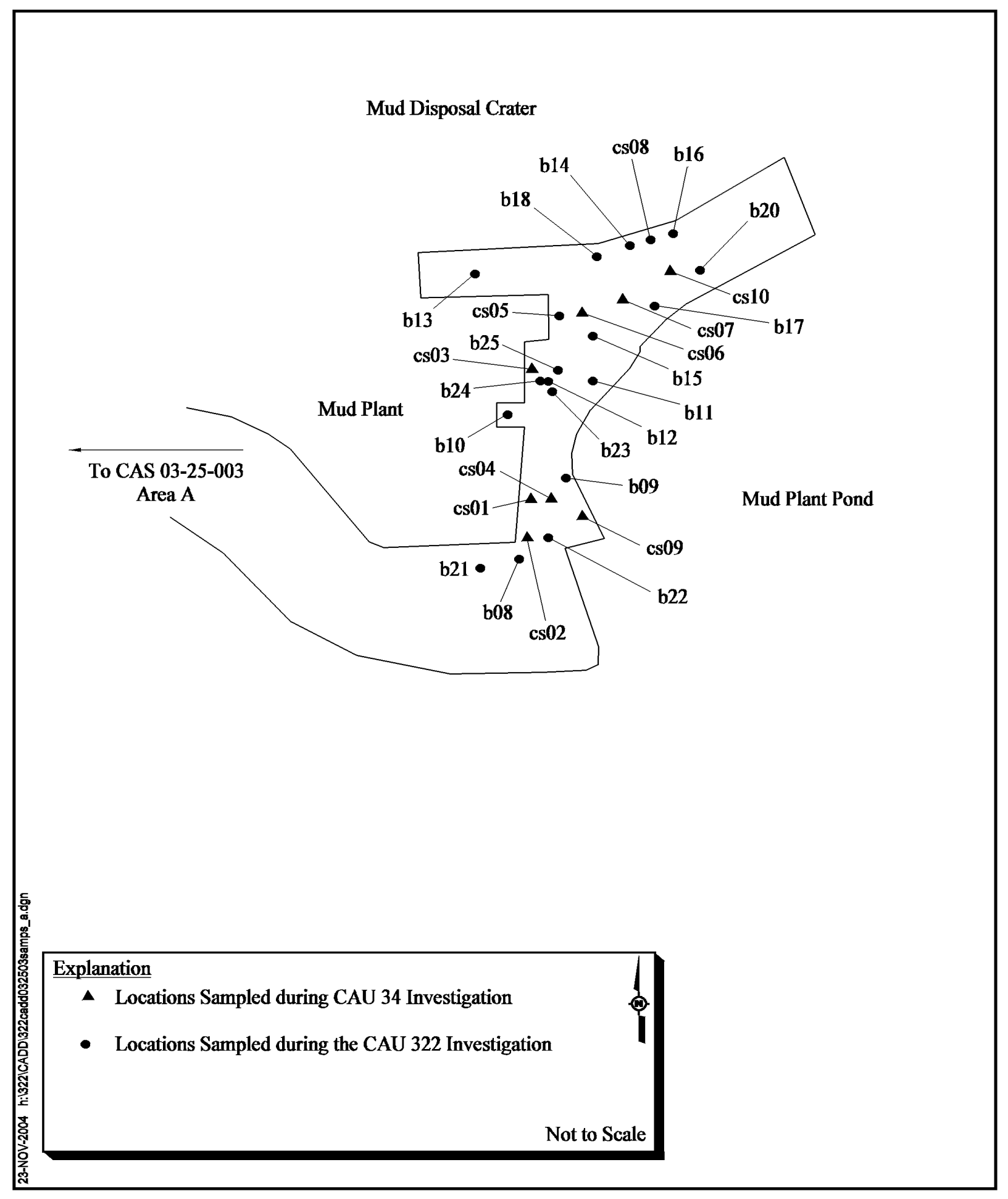

Figure A.4-2

Sample Location Map for CAS 03-25-03, AST Release Area B, Mud Plant 
Table A.4-2

Samples Collected During the CAU 34 CAI at CAS 03-25-03, Area B (East of Mud Plant)

\begin{tabular}{|c|c|c|c|c|}
\hline $\begin{array}{l}\text { Sample } \\
\text { Location }\end{array}$ & $\begin{array}{l}\text { Sample } \\
\text { Number }\end{array}$ & $\begin{array}{c}\text { Depth } \\
\text { (ft bgs) }\end{array}$ & $\begin{array}{c}\text { Sample } \\
\text { Matrix }\end{array}$ & Analyses \\
\hline \multirow{3}{*}{ CS-01 } & CS0100 & $0-0.5$ & soil & $\mathrm{TPH}$ \\
\hline & CS0101 & $0.5-1.5$ & soil & TPH \\
\hline & CS0102 & $1.5-2.5$ & soil & $\mathrm{TPH}$ \\
\hline \multirow{3}{*}{ CS-02 } & CS0200 & $0-0.5$ & soil & TPH \\
\hline & CS0201 & $0.5-1.5$ & soil & TPH \\
\hline & CS0202 & $1.5-2.5$ & soil & $\mathrm{TPH}$ \\
\hline \multirow{4}{*}{ CS-03 } & CS0300 & $0-0.5$ & soil & TPH \\
\hline & CS0301 & $0.5-1.5$ & soil & $\mathrm{TPH}$ \\
\hline & CS0302 & $1.5-2.5$ & soil & $\mathrm{TPH}$ \\
\hline & CS0306 & $6-7$ & soil & TPH \\
\hline \multirow{3}{*}{ CS-04 } & CS0400 & $0-0.5$ & soil & $\mathrm{TPH}$ \\
\hline & CS0401 & $1-2$ & soil & TPH \\
\hline & CS0402 & $2-3$ & soil & $\mathrm{TPH}$ \\
\hline \multirow{3}{*}{ CS-06 } & CS0601 & $1.5-2.5$ & soil & TPH \\
\hline & CS0699 & $1.5-2.5$ & soil & $\mathrm{TPH}$ \\
\hline & CS0610 & $10-12$ & soil & TPH \\
\hline CS-07 & CS0710 & $10-12$ & soil & TPH \\
\hline \multirow{2}{*}{ CS-08 } & CS0806 & $6-7$ & soil & $\mathrm{TPH}$ \\
\hline & CS0810 & $10-12$ & soil & $\mathrm{TPH}$ \\
\hline CS-09 & CS0902 & $2.5-3.5$ & soil & $\mathrm{TPH}$ \\
\hline \multirow{2}{*}{ CS-10 } & CS1002 & $2.5-3.5$ & soil & TPH \\
\hline & CS1006 & $6-7$ & soil & $\mathrm{TPH}$ \\
\hline
\end{tabular}

$\mathrm{ft}$ bgs $=$ Feet below ground surface 


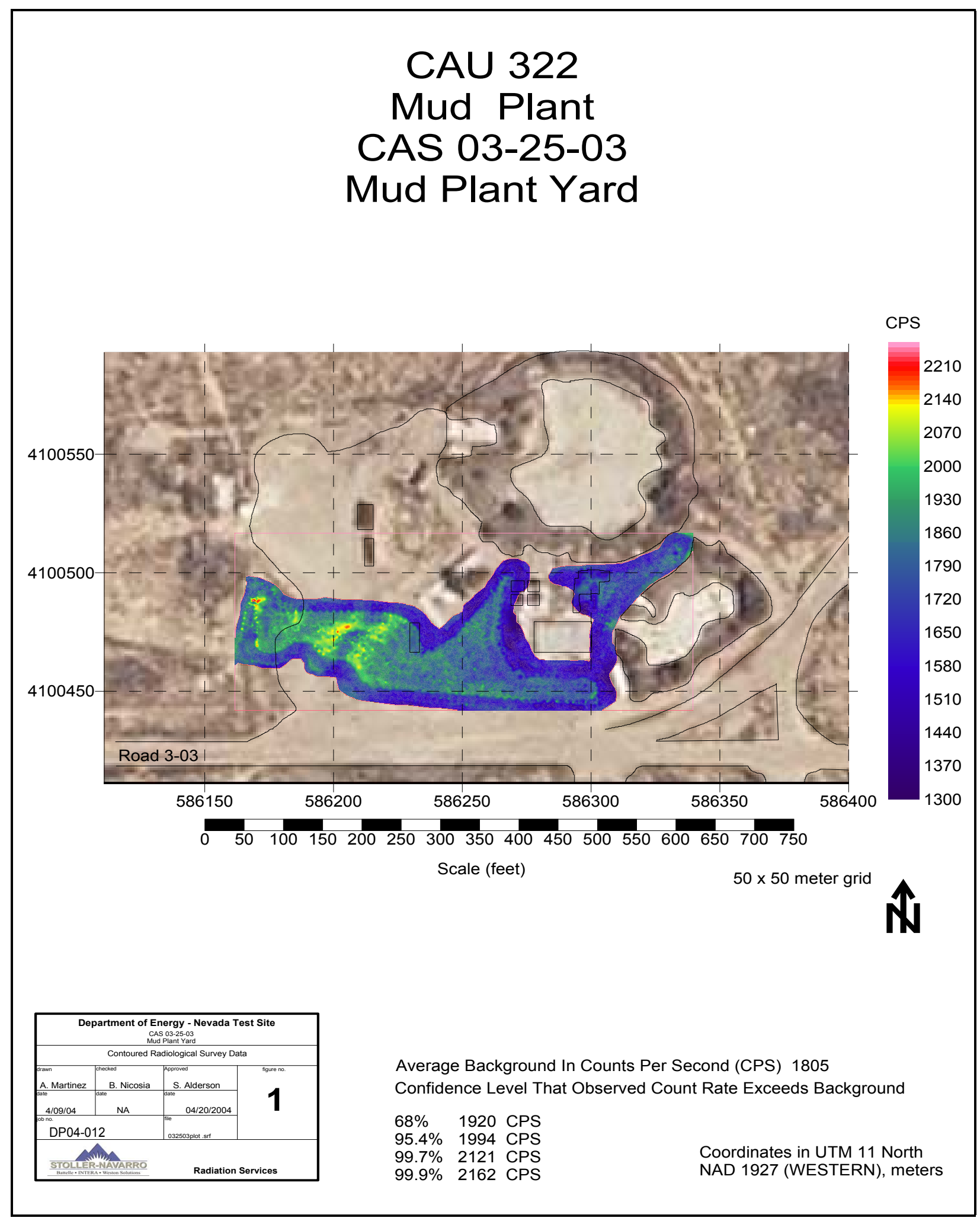

Figure A.4-3

Radiological Survey Map for CAS 03-25-03, AST Release 
predesignated locations throughout the CAS. Decision II soil sampling was necessary to define the extent of contamination at Area B. In addition a swipe sample was collected from a concrete pad located beneath a shallow soil layer where a elevated area of radiological activity was identified at Area B.

Confirmation soil samples were collected after the removal of a small amount of TPH-DRO contaminated soil at Area A.

\section{A.4.2.3 Field-Screening Results}

Field-screening results for VOCs using a FID provided no readings above the FSL of $20 \mathrm{mg} / \mathrm{kg}$. Field-screening results obtained using a thermal desorption gas chromatograph with FID detector indicated the presence of TPH-DRO above the PAL at various locations and was used to guide additional sampling. Field-screening results for radiological contamination provided no results above background.

\section{A.4.2.4 Sample Analysis}

Investigation samples were analyzed for the CAIP-specified COPCs which included total RCRA metals and total beryllium, total VOCs, total SVOCs, PCBs, TPH (DRO/GRO), gamma-emitting radionuclides, isotopic uranium, isotopic plutonium, and strontium-90. The analytical parameters and laboratory methods used to analyze the investigation samples are listed in Table A.2-2. Table A.4-1 lists the sample-specific analytical suite for CAS 03-25-03.

\section{A.4.2.5 Analytes Detected Above Minimum Reporting Limits}

Analytical results from the soil samples with concentrations exceeding MRLs or MDCs are summarized in the following sections. These results are compared to PALs and are a subset of the results that exceed MRLs or MDCs. Results greater than PALs are identified by bold text in the analytical tables. A portion of the analytical results for this CAS were rejected during validation; however, these rejected data did not adversely impact closure decisions as discussed in Appendix B, Section B.1.4. 


\section{A.4.2.5.1 Total VOCs}

Total VOC analytical results for soil samples collected at CAS 03-25-03, which were detected above MRLs, are presented in Table A.4-3. No VOCs were detected in soil samples above PALs.

Table A.4-3

Soil Sample Results for Total VOCs Detected Above Minimum Reporting Limits at CAS 03-25-03, Mud Plant AST Diesel Release

\begin{tabular}{|c|c|c|c|}
\hline \multirow{2}{*}{$\begin{array}{c}\text { Sample } \\
\text { Location }\end{array}$} & $\begin{array}{c}\text { Sample } \\
\text { Number }\end{array}$ & $\begin{array}{c}\text { Depth } \\
\text { (ft bgs) }\end{array}$ & Contaminants of Potential Concern $(\mu \mathbf{g} / \mathbf{k g})$ \\
\cline { 3 - 4 } & & Acetone \\
\hline \hline \multicolumn{2}{|c|}{ Preliminary Action Levels } & $\mathbf{6 , 0 0 0 , 0 0 0}$ \\
\hline B08 & $322 \mathrm{~B} 053$ & $2-3$ & 23 \\
\hline \multirow{2}{*}{ B18 } & $322 \mathrm{~B} 056$ & $15-16$ & 33 \\
\cline { 2 - 4 } & $322 \mathrm{~B} 057$ & $20-21$ & 36 \\
\hline
\end{tabular}

aased on U.S. Environmental Protection Agency, Region 9 Preliminary Remediation Goals (PRGs) (EPA, 2002)

$\mathrm{ft}$ bgs $=$ Feet below ground surface $\mu \mathrm{g} / \mathrm{kg}=$ Micrograms per kilogram

\section{A.4.2.5.2 Total SVOCs}

Total SVOC analytical results for soil samples collected at CAS 03-25-03, which were detected above MRLs, are presented in Table A.4-4. No SVOCs were detected in soil samples above PALs.

Table A.4-4

Soil Sample Result for Total SVOCs Detected Above Minimum Reporting Limits at CAS 03-25-03, Mud Plant AST Diesel Release

\begin{tabular}{|c|c|c|c|}
\hline \multirow{2}{*}{$\begin{array}{c}\text { Sample } \\
\text { Location }\end{array}$} & $\begin{array}{c}\text { Sample } \\
\text { Number }\end{array}$ & $\begin{array}{c}\text { Depth } \\
(\mathbf{f t} \text { bgs })\end{array}$ & Contaminants of Potential Concern $(\mu \mathrm{g} / \mathrm{kg})$ \\
\cline { 4 - 4 } & & & Di-N-Butyl Phthalate \\
\hline \multicolumn{2}{|c|}{ Preliminary Action Levels ${ }^{\mathrm{a}}$} & $\mathbf{6 2 , 0 0 0 , 0 0 0}$ \\
\hline \hline B07 & $322 \mathrm{~B} 002$ & $0-0.5$ & 370 \\
\hline
\end{tabular}

aBased on U.S. Environmental Protection Agency, Region 9 Preliminary Remediation Goals (PRGs) (EPA, 2002)

$\mathrm{ft}$ bgs $=$ Feet below ground surface $\mu \mathrm{g} / \mathrm{kg}=$ Micrograms per kilogram 


\section{A.4.2.5.3 PCBs}

Polychlorinated biphenyl analytical results for soil samples collected at CAS 03-25-03, which were detected above MRLs, are presented in Table A.4-5. No PCBs were detected in soil samples above PALs.

Table A.4-5

Soil Sample Results for PCBs Detected Above Minimum Reporting Limits at CAS 03-25-03, Mud Plant AST Diesel Release

\begin{tabular}{|c|c|c|c|c||}
\hline \multirow{2}{*}{$\begin{array}{c}\text { Sample } \\
\text { Location }\end{array}$} & $\begin{array}{c}\text { Sample } \\
\text { Number }\end{array}$ & $\begin{array}{c}\text { Depth } \\
(\mathrm{ft} \text { bgs) }\end{array}$ & \multicolumn{2}{c|}{ Contaminants of Potential Concern $(\mu \mathrm{g} / \mathrm{kg})$} \\
\cline { 3 - 5 } & & Aroclor 1016 & Aroclor 1254 \\
\hline \multicolumn{3}{|c|}{ Preliminary Action Levels } & $\mathbf{2 1 , 0 0 0}$ & $\mathbf{7 4 0}$ \\
\hline \hline B08 & 322B012 & $0-0.5$ & -- & $94(\mathrm{~J})$ \\
\hline B15 & $322 \mathrm{~B} 020$ & $0-0.5$ & 41 & -- \\
\hline
\end{tabular}

${ }^{\mathrm{a} B a s e d}$ on U.S. Environmental Protection Agency, Region 9 Preliminary Remediation Goals (PRGs) (EPA, 2002)

$\mathrm{ft}$ bgs $=$ Feet below ground surface $\mu \mathrm{g} / \mathrm{kg}=$ Micrograms per kilogram

$--=$ Not detected above minimum reporting limits

$\mathrm{J}=$ Estimated value; qualifier added to laboratory data, record accepted; percent difference between columns $>25$.

\section{A.4.2.5.4 Total RCRA Metals and Beryllium}

Total RCRA metals and beryllium analytical results for soil samples collected at CAS 03-25-03, which were detected above MRLs, are presented in Table A.4-6. No metals were detected in soil samples above PALs.

\section{A.4.2.5.5 TPH (DRO/GRO)}

Total petroleum hydrocarbons analytical results for soil samples collected at CAS 03-25-03, which were detected above MRLs, are presented in Table A.4-7. Table A.4-7 also identifies the portion of CAS 03-25-03 from which each sample was collected (i.e., Area A or B). The results for each of these areas are discussed in following subsections. 
Table A.4-6

Soil Sample Results for Metals Detected Above Minimum Reporting Limits at CAS 03-25-03, Mud Plant AST Diesel Release (Page 1 of 5)

\begin{tabular}{|c|c|c|c|c|c|c|c|c|c|c|c|}
\hline \multirow[b]{2}{*}{$\begin{array}{c}\text { Sample } \\
\text { Location }\end{array}$} & \multirow[b]{2}{*}{$\begin{array}{l}\text { Sample } \\
\text { Number }\end{array}$} & \multirow[b]{2}{*}{$\begin{array}{c}\text { Depth } \\
\text { (ft bgs) }\end{array}$} & \multicolumn{9}{|c|}{ Contaminants of Potential Concern (mg/kg) } \\
\hline & & & 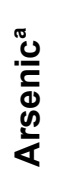 & 롤 & 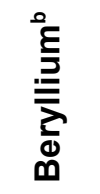 & 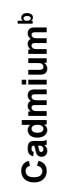 & 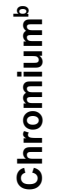 & 용 & 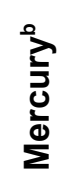 & है & $\stackrel{\stackrel{2}{d}}{\frac{2}{\bar{\omega}}}$ \\
\hline \multicolumn{3}{|c|}{ Preliminary Action Levels } & 23 & 67,000 & 1,900 & 450 & 450 & 750 & 310 & 5,100 & 5,100 \\
\hline \multirow{3}{*}{ B01 } & 322B007 & $0-0.5$ & $\overline{4.3}$ & $\overline{140}$ & 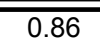 & $\overline{---}$ & $\overline{6.5}$ & $\overline{10}$ & $\overline{---}$ & $\overline{0.58(J)^{c}}$ & $\overline{---}$ \\
\hline & 322B038 & $2-3$ & 4.4 & 140 & 0.79 & -- & 6 & 16 & -- & -- & -- \\
\hline & 322B039 & $19-20$ & 4.1 & 120 & 0.6 & -- & 5.5 & 8 & -- & -- & -- \\
\hline \multirow{3}{*}{ B02 } & 322B008 & $0-0.5$ & 4.6 & 200 & 0.83 & -- & 6.3 & 13 & -- & $0.81(\mathrm{~J})^{\mathrm{C}}$ & -- \\
\hline & 322B036 & $2-3$ & 5 & 140 & 0.87 & -- & 6.7 & 11 & -- & -- & -- \\
\hline & 322B037 & $19-20$ & 3.5 & 170 & 0.64 & -- & 4.9 & 7.3 & -- & -- & -- \\
\hline \multirow{4}{*}{ B03 } & 322B009 & $0-0.5$ & 4.3 & 130 & 0.81 & -- & 6 & 11 & - & - & $\overline{--}$ \\
\hline & 322B033 & $2-3$ & 4.6 & 140 & 0.79 & -- & 5.8 & 9.2 & -- & -- & -- \\
\hline & 322B034 & $2-3$ & 4.2 & 150 & 0.78 & -- & 5.7 & 10 & -- & 0.63 & -- \\
\hline & 322B035 & $19-20$ & 4 & 130 & 0.61 & -- & 4.7 & 8.3 & -- & -- & -- \\
\hline \multirow{3}{*}{ B04 } & 322B010 & $0-0.5$ & 4.6 & 250 & 0.75 & -- & 6.4 & 27 & -- & -- & -- \\
\hline & 322B028 & $2-3$ & 3 & 140 & 0.61 & -- & 4.1 & 7.5 & -- & -- & -- \\
\hline & 322B032 & $19-20$ & 5 & 150 & 0.68 & -- & 7.6 & 11 & -- & -- & -- \\
\hline \multirow{6}{*}{ B05 } & 322B011 & $0-0.5$ & 4 & 160 & 0.83 & $\overline{--}$ & 5.3 & 10 & $\overline{--}$ & -- & $\overline{--}$ \\
\hline & 322B023 & $3-4$ & 4 & 160 & 0.64 & -- & 4.3 & 9.5 & -- & -- & -- \\
\hline & 322B024 & $7-8$ & 3.7 & 100 & 0.75 & -- & 5.3 & 8.9 & - & - & -- \\
\hline & 322B025 & $11-12$ & 3.9 & 82 & 0.79 & -- & 5.2 & 9.6 & -- & -- & -- \\
\hline & 322B026 & $15-16$ & 4.6 & 170 & 0.71 & -- & 8.2 & 9.4 & -- & -- & -- \\
\hline & 322B027 & $19-20$ & 4.5 & 120 & 0.62 & -- & 6.3 & 7.4 & -- & -- & -- \\
\hline
\end{tabular}


Table A.4-6

Soil Sample Results for Metals Detected Above Minimum Reporting Limits at CAS 03-25-03, Mud Plant AST Diesel Release (Page 2 of 5 )

\begin{tabular}{|c|c|c|c|c|c|c|c|c|c|c|c|}
\hline \multirow[b]{2}{*}{$\begin{array}{l}\text { Sample } \\
\text { Location }\end{array}$} & \multirow[b]{2}{*}{$\begin{array}{l}\text { Sample } \\
\text { Number }\end{array}$} & \multirow[b]{2}{*}{$\begin{array}{c}\text { Depth } \\
\text { (ft bgs) }\end{array}$} & \multicolumn{9}{|c|}{ Contaminants of Potential Concern (mg/kg) } \\
\hline & & & 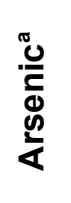 & 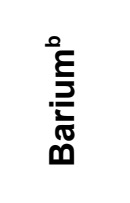 & 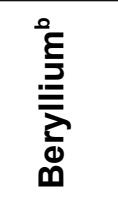 & है & 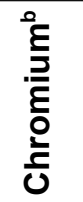 & 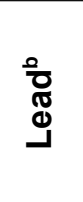 & 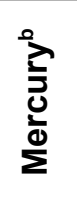 & 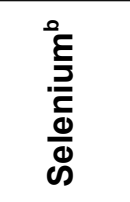 & $\frac{\stackrel{2}{d}}{\bar{D}}$ \\
\hline \multicolumn{3}{|c|}{ Preliminary Action Levels } & 23 & 67,000 & 1,900 & 450 & 450 & 750 & 310 & 5,100 & 5,100 \\
\hline \multirow{4}{*}{ B06 } & 322B001 & $0-0.5$ & 4.5 & 260 & 0.63 & $\overline{--}$ & 6.5 & $\overline{9} 9.5$ & $\overline{---}$ & $\overline{1(J)^{c}}$ & $\overline{---}$ \\
\hline & 322B003 & $2-3$ & 4.6 & 140 & 0.89 & -- & 6.6 & 11 & -- & $0.75(J)^{c}$ & -- \\
\hline & 322B004 & $6-7$ & 4.2 & 120 & -- & -- & 4 & 8.7 & -- & -- & -- \\
\hline & 322B021 & $15-16$ & 3.7 & 160 & 0.86 & -- & 4.8 & 9.8 & -- & -- & -- \\
\hline \multirow{4}{*}{ B07 } & 322B002 & $0-0.5$ & 5.2 & 210 & 0.73 & -- & 7.2 & 9.4 & -- & $0.66(\mathrm{~J})^{\mathrm{c}}$ & -- \\
\hline & 322B005 & $2-3$ & 6 & 140 & 0.97 & -- & 7.2 & 11 & -- & $0.71(\mathrm{~J})^{\mathrm{c}}$ & -- \\
\hline & 322B006 & $5-6$ & 8 & 120 & 0.97 & -- & 7.9 & 11 & -- & $0.64(\mathrm{~J})^{\mathrm{c}}$ & -- \\
\hline & 322B022 & $15-16$ & 4.9 & 180 & 0.7 & -- & 7.9 & 10 & -- & -- & -- \\
\hline \multirow{4}{*}{ B08 } & 322B012 & $0-0.5$ & 5.6 & 770 & 0.7 & -- & 17 & 15 & -- & $0.65(\mathrm{~J})^{\mathrm{c}}$ & -- \\
\hline & 322B053 & $2-3$ & 4.2 & 580 & 0.62 & -- & 14 & 12 & -- & -- & -- \\
\hline & 322B054 & $14-15$ & 3.9 & 120 & 0.54 & -- & 8 & 6.6 & -- & -- & -- \\
\hline & 322B055 & $14-15$ & 4.6 & 150 & 0.64 & -- & 6.9 & 9.4 & -- & -- & -- \\
\hline \multirow{3}{*}{ B09 } & 322B013 & $0-0.5$ & 6.3 & 820 & 0.69 & -- & 15 & 11 & -- & $0.77(\mathrm{~J})^{\mathrm{c}}$ & -- \\
\hline & 322B051 & $2-3$ & 4.1 & 140 & 0.73 & -- & 6.1 & 9.8 & - & - & -- \\
\hline & 322B052 & $14-15$ & 3 & 130 & -- & -- & 8.1 & 6.1 & -- & -- & -- \\
\hline B10 & 322B014 & $0-0.5$ & 5.6 & 1,300 & 0.74 & $1.6(\mathrm{~J}-)^{\mathrm{d}}$ & 16 & 20 & 0.11 & $0.73(\mathrm{~J})^{\mathrm{c}}$ & -- \\
\hline
\end{tabular}


Table A.4-6

Soil Sample Results for Metals Detected Above Minimum Reporting Limits at CAS 03-25-03, Mud Plant AST Diesel Release (Page 3 of 5)

\begin{tabular}{|c|c|c|c|c|c|c|c|c|c|c|c|}
\hline \multirow[b]{2}{*}{$\begin{array}{c}\text { Sample } \\
\text { Location }\end{array}$} & \multirow[b]{2}{*}{$\begin{array}{l}\text { Sample } \\
\text { Number }\end{array}$} & \multirow[b]{2}{*}{$\begin{array}{c}\text { Depth } \\
\text { (ft bgs) }\end{array}$} & \multicolumn{9}{|c|}{ Contaminants of Potential Concern $(\mathrm{mg} / \mathrm{kg})$} \\
\hline & & & 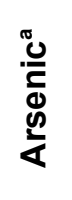 & 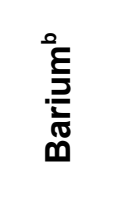 & 로 & 疋 & 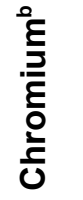 & తొర్తి & 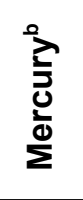 & 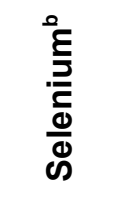 & 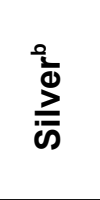 \\
\hline \multicolumn{3}{|c|}{ Preliminary Action Levels } & 23 & 67,000 & 1,900 & 450 & 450 & 750 & 310 & 5,100 & 5,100 \\
\hline \multirow{3}{*}{ B11 } & 322B015 & $0-0.5$ & 5.1 & 580 & 0.73 & -- & 14 & 12 & $\overline{--}$ & $0.83(\mathrm{~J})^{\mathrm{c}}$ & $\overline{--}$ \\
\hline & 322B047 & $2-3$ & 3.9 & 120 & 0.68 & -- & 5.9 & 9.3 & -- & -- & -- \\
\hline & 322B048 & $14-15$ & 3.3 & 91 & -- & -- & 4.3 & 6.8 & -- & -- & -- \\
\hline \multirow{4}{*}{ B12 } & 322B016 & $0-0.5$ & 3.6 & 180 & 0.72 & -- & 7 & 9.1 & -- & -- & -- \\
\hline & 322B017 & $0-0.5$ & 4 & 200 & 0.72 & -- & 6.2 & 12 & -- & $0.52(J)^{c}$ & -- \\
\hline & 322B049 & $2-3$ & 3.5 & 140 & 0.6 & -- & 5.5 & 7.9 & - & -- & - \\
\hline & 322B050 & $14-15$ & 4.4 & 100 & -- & -- & 7.2 & 7 & - & -- & -- \\
\hline \multirow{3}{*}{ B13 } & 322B018 & $0-0.5$ & 5.6 & 680 & 0.74 & -- & 15 & 11 & -- & -- & -- \\
\hline & 322B040 & $2-3$ & 3.9 & 130 & -- & -- & 5.2 & 8.3 & -- & -- & -- \\
\hline & 322B041 & $14-15$ & 3.9 & 110 & 0.84 & -- & 6.9 & 11 & -- & $0.56(\mathrm{~B})$ & - \\
\hline \multirow{3}{*}{ B14 } & 322B019 & $0-0.5$ & 5.7 & 370 & 0.7 & -- & 10 & 12 & -- & $0.67(\mathrm{~J})^{\mathrm{c}}$ & -- \\
\hline & 322B042 & $2-3$ & 3.1 & 120 & -- & -- & 5.3 & 7.4 & -- & -- & -- \\
\hline & 322B043 & $14-15$ & 4.3 & 88 & 0.56 & -- & 8.3 & 7.9 & -- & 0.55 & -- \\
\hline \multirow{4}{*}{ B15 } & 322B020 & $0-0.5$ & 4.5 & 1,400 & 0.67 & -- & 18 & 16 & -- & $0.52(\mathrm{~J})^{\mathrm{c}}$ & -- \\
\hline & 322B044 & $2-3$ & 3.7 & 190 & 0.77 & -- & 6 & 11 & -- & -- & -- \\
\hline & 322B045 & $10-11$ & 3 & 210 & -- & -- & 3.2 & 13 & -- & -- & -- \\
\hline & 322B046 & $14-15$ & 5.3 & 98 & 0.6 & -- & 10 & 8 & -- & 0.86 & -- \\
\hline
\end{tabular}


Table A.4-6

Soil Sample Results for Metals Detected Above Minimum Reporting Limits at CAS 03-25-03, Mud Plant AST Diesel Release (Page 4 of 5)

\begin{tabular}{|c|c|c|c|c|c|c|c|c|c|c|c|}
\hline \multirow[b]{2}{*}{$\begin{array}{c}\text { Sample } \\
\text { Location }\end{array}$} & \multirow[b]{2}{*}{$\begin{array}{l}\text { Sample } \\
\text { Number }\end{array}$} & \multirow[b]{2}{*}{$\begin{array}{c}\text { Depth } \\
\text { (ft bgs) }\end{array}$} & \multicolumn{9}{|c|}{ Contaminants of Potential Concern $(\mathrm{mg} / \mathrm{kg})$} \\
\hline & & & 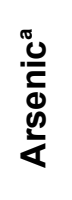 & हี & 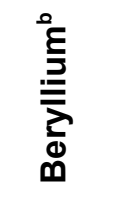 & 疋 & 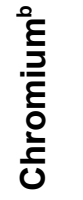 & 욣 & 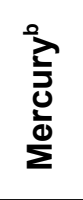 & 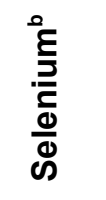 & $\stackrel{\frac{2}{0}}{\frac{1}{\omega}}$ \\
\hline \multicolumn{3}{|c|}{ Preliminary Action Levels } & 23 & 67,000 & 1,900 & 450 & 450 & 750 & 310 & 5,100 & 5,100 \\
\hline \multirow{3}{*}{ B16 } & 322B059 & $1-2$ & 4.9 & $360(J)^{e}$ & $0.69(\mathrm{~J})^{f}$ & -- & 8.8 & $11(\mathrm{~J})^{\mathrm{e}}$ & $\overline{--}$ & $\overline{--}$ & -- \\
\hline & 322B060 & $15-16$ & 5.3 & $120(J)^{e}$ & $0.7(J)^{f}$ & -- & 7.7 & $12(\mathrm{~J})^{\mathrm{e}}$ & -- & -- & -- \\
\hline & 322B061 & $20-21$ & 5.7 & $140(\mathrm{~J})^{\mathrm{e}}$ & $1.1(J)^{f}$ & -- & 8.1 & $11(\mathrm{~J})^{\mathrm{e}}$ & -- & -- & -- \\
\hline \multirow{2}{*}{ B17 } & 322B062 & $2-3$ & 5 & $140(J)^{e}$ & $0.72(\mathrm{~J})^{f}$ & -- & 6.3 & $12(\mathrm{~J})^{\mathrm{e}}$ & -- & -- & -- \\
\hline & 322B063 & $7-8$ & 2.7 & $98(J)^{\mathrm{e}}$ & -- & -- & 3.7 & $7.6(\mathrm{~J})^{\mathrm{e}}$ & -- & -- & -- \\
\hline \multirow{3}{*}{ B18 } & 322B056 & $15-16$ & 4.9 & $110(\mathrm{~J})^{\mathrm{e}}$ & -- & -- & 12 & $8.6(J)^{e}$ & -- & -- & -- \\
\hline & 322B057 & $20-21$ & 5.6 & $210(\mathrm{~J})^{\mathrm{e}}$ & $0.71(J)^{f}$ & -- & 11 & $9.3(J)^{\mathrm{e}}$ & -- & -- & -- \\
\hline & 322B058 & $25-26$ & 4.4 & $150(\mathrm{~J})^{\mathrm{e}}$ & $0.87(\mathrm{~J})^{f}$ & -- & 5.5 & $9.3(\mathrm{~J})^{\mathrm{e}}$ & -- & -- & -- \\
\hline \multirow{4}{*}{ B19 } & 322B064 & $0-1$ & 4.5 & $130(\mathrm{~J})^{\mathrm{e}}$ & $0.71(J)^{f}$ & -- & 6 & $11(\mathrm{~J})^{\mathrm{e}}$ & -- & 0.63 & -- \\
\hline & 322B065 & $15-16$ & 4.8 & $140(\mathrm{~J})^{\mathrm{e}}$ & $0.81(J)^{f}$ & -- & 7.3 & $11(\mathrm{~J})^{\mathrm{e}}$ & -- & 0.73 & -- \\
\hline & 322B066 & $19-20$ & 4.6 & $180(\mathrm{~J})^{\mathrm{e}}$ & $0.71(J)^{f}$ & -- & 5.5 & $8(\mathrm{~J})^{\mathrm{e}}$ & -- & -- & -- \\
\hline & 322B067 & $19-20$ & 4.1 & $160(\mathrm{~J})^{\mathrm{e}}$ & $0.73(\mathrm{~J})^{f}$ & -- & 6.5 & $9.9(\mathrm{~J})^{\mathrm{e}}$ & -- & -- & -- \\
\hline
\end{tabular}


Table A.4-6

Soil Sample Results for Metals Detected Above Minimum Reporting Limits at CAS 03-25-03, Mud Plant AST Diesel Release (Page 5 of 5 )

\begin{tabular}{|c|c|c|c|c|c|c|c|c|c|c|c|}
\hline \multirow[b]{2}{*}{$\begin{array}{c}\text { Sample } \\
\text { Location }\end{array}$} & \multirow[b]{2}{*}{$\begin{array}{l}\text { Sample } \\
\text { Number }\end{array}$} & \multirow[b]{2}{*}{$\begin{array}{c}\text { Depth } \\
\text { (ft bgs) }\end{array}$} & \multicolumn{9}{|c|}{ Contaminants of Potential Concern (mg/kg) } \\
\hline & & & 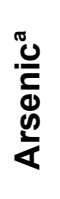 & 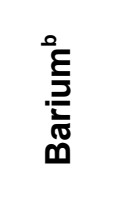 & 롤 & 疋 & 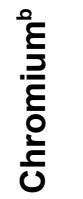 & తొర్త & $\begin{array}{l}\sum^{2} \\
\frac{0}{0} \\
\frac{0}{0} \\
\Sigma\end{array}$ & 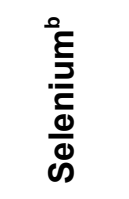 & 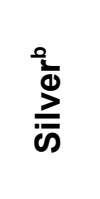 \\
\hline \multicolumn{3}{|c|}{ Preliminary Action Levels } & 23 & 67,000 & 1,900 & 450 & 450 & 750 & 310 & 5,100 & 5,100 \\
\hline \multirow{3}{*}{ B20 } & $\overline{\text { 322B068 }}$ & $2-3$ & $\overline{4.6}$ & $\overline{130}$ & $\overline{0.71}$ & $\overline{---}$ & $\overline{\overline{8.7}}$ & $\overline{8.8}$ & $\overline{---}$ & $\overline{---}$ & $\overline{\overline{3.2}}$ \\
\hline & 322B069 & $6-7$ & 5.5 & 210 & 0.69 & -- & 13 & 16 & -- & -- & -- \\
\hline & 322B070 & $19-20$ & 4.6 & 110 & 0.86 & -- & 6.5 & 9.9 & -- & $0.77(\mathrm{~J}-)^{\mathrm{g}}$ & -- \\
\hline
\end{tabular}

a Based on the background concentrations for metals. Background is considered the mean plus two times the standard deviation for sediment samples collected by the Nevada Bureau of Mines and Geology throughout the Nevada Test and Training Range (NBMG, 1998; Moore, 1999).

${ }^{\mathrm{b}}$ Based on U.S. Environmental Protection Agency, Region 9 Preliminary Remediation Goals (PRGs) (EPA, 2002)

${ }^{6} Q$ Qualifier added to laboratory data; record accepted. Value less than 5 times contamination in continuing calibration/method blank.

dMatrix spike recovery outside control limits. Duplicate precision analysis (relative percent difference) outside control limits.

Qualifier added to laboratory data; record accepted. Matrix spike recovery outside control limits.

Qualifier added to laboratory data; record accepted. Serial dilution \%D outside control limits. Matrix effects may exist.

9Negative bias found in continuing calibration/method blank.

$\mathrm{ft}$ bgs $=$ Feet below ground surface

$\mathrm{mg} / \mathrm{kg}=$ Milligrams per kilogram

$\mathrm{B}=$ Analyte found in both sample and associated blank.

$\mathrm{J}=$ Estimated value.

$\mathrm{J}-=$ The result is an estimated quantity, but the result may be biased low.

- = Not detected above minimum reporting limits 
Table A.4-7

Soil Sample Results for TPH (DRO and GRO) Detected Above Minimum Reporting Limits at CAS 03-25-03, Mud Plant AST Diesel Release

\begin{tabular}{|c|c|c|c|c|c|}
\hline \multirow{2}{*}{$\begin{array}{l}\text { Sample } \\
\text { Location }\end{array}$} & \multirow{2}{*}{ Area } & \multirow{2}{*}{$\begin{array}{l}\text { Sample } \\
\text { Number }\end{array}$} & \multirow{2}{*}{$\begin{array}{l}\text { Depth } \\
\text { (ft bgs) }\end{array}$} & \multicolumn{2}{|c|}{ Contaminants of Potential Concern (mg/kg) } \\
\hline & & & & \multirow{2}{*}{$\begin{array}{c}\text { Diesel Range Organics } \\
100\end{array}$} & Gasoline Range Organics \\
\hline \multicolumn{4}{|c|}{ Preliminary Action Levels ${ }^{a}$} & & 100 \\
\hline$\overline{\mathrm{B} 01}$ & \multirow{2}{*}{ A } & 322B038 & $2-3$ & $140(\mathrm{D}, \mathrm{H}, \mathrm{M})$ & 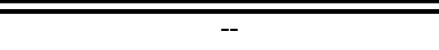 \\
\hline B04 & & 322B010 & $0-0.5$ & $370(H, M)$ & $\overline{--}$ \\
\hline \multirow{2}{*}{ B08 } & \multirow{9}{*}{ B } & 322B012 & $0-0.5$ & $72(\mathrm{H}, \mathrm{M})$ & $\overline{--}$ \\
\hline & & 322B053 & $2-3$ & $170(\mathrm{H}, \mathrm{M})$ & $\overline{--}$ \\
\hline B09 & & 322B051 & $2-3$ & $74(\mathrm{H}, \mathrm{M})$ & -- \\
\hline B10 & & 322B014 & $0-0.5$ & $76(H, M)$ & -- \\
\hline B11 & & 322B015 & $0-0.5$ & $86(\mathrm{H}, \mathrm{M})$ & $\overline{--}$ \\
\hline B14 & & 322B043 & $14-15$ & $300(H, Y)$ & -- \\
\hline \multirow{2}{*}{ B15 } & & 322B020 & $0-0.5$ & $150(\mathrm{H}, \mathrm{M})$ & $\overline{--}$ \\
\hline & & 322B044 & $2-3$ & $4,000(Y)$ & $5.3(\mathrm{H})$ \\
\hline B17 & & 322B062 & $2-3$ & $1,500(\mathrm{H}, \mathrm{M})$ & -- \\
\hline
\end{tabular}

aBased on Nevada Administrative Code; Contamination of soil: Establishment of action levels (NAC, 2002)

$\mathrm{ft}$ bgs $=$ Feet below ground surface $\mathrm{mg} / \mathrm{kg}=$ Milligrams per kilogram

$\mathrm{D}=\mathrm{A}$ pattern resembling diesel was detected in the sample.

$\mathrm{H}=$ The fuel pattern was in the heavier end of the retention time window for the analyte of interest

$M=A$ pattern resembling motor oil was detected

$\mathrm{Y}=$ Multipeak chromatogram does not match target analyte

-- = Not detected above minimum reporting limits

Total petroleum hydrocarbon-DRO was identified at two locations in Area A. One location (B04) contained TPH-DRO above the PAL. Based on visual observation of the sample location it is possible the positive TPH-DRO results may be due to the presence of paint chips (from oil based paint) which appear to have flaked off of an old wooden road barricade that was found lying directly on top of the sample location. Approximately 2 cubic feet $\left(\mathrm{ft}^{3}\right)$ of soil was removed and drummed, and the underlying soil sampled. The analytical results of this verification sample indicate the contamination above PALs was removed.

The second location (B01) contained TPH-DRO contamination above the PAL at the 2 to $3 \mathrm{ft}$ bgs interval. The overlying soil was removed and the 2 to $3 \mathrm{ft}$ bgs interval (approximately $4 \mathrm{ft}^{3}$ ) was collected and drummed. Confirmation samples were collected from the excavation floor and from the 
sides of the excavation at the 2 to $3 \mathrm{ft}$ bgs interval. Analytical results indicated that the TPH-DRO contamination was removed. No TPH-DRO contamination remained at Area A.

Sampling at sites B06 and B07 were intended to determine if TPH-DRO contamination had migrated along a buried utility corridor and showed up as TPH-DRO contamination at Area B. This was determined not to be the case, and Areas A and B were isolated as discreet areas of interest within this CAS.

At Area B, TPH-DRO was identified at several locations and various depths. Each of the TPH-DRO detections above the PAL and all other samples collected from the same borehole are presented in Table A.4-8. The identification of TPH-DRO contaminated locations in Area B do not appear to be associated with specific identifiable point sources of contamination. There is no anticipated gradient of contamination, as expected when a point source (e.g., fuel overfilling, leaking piping, tank rupture) is identifiable. The highest concentrations of TPH-DRO are not associated with surface samples, but instead with deeper subsurface samples at noncontiguous locations. The TPH-DRO contamination is defined laterally where physical barriers do not interfere with step-out locations (Figure A.4-4). The vertical extent of contamination is defined at each location where TPH was detected above PALs as shown in Table A.4-8 except where otherwise noted. Figure A.4-5 provides a cross section view of the TPH-DRO contamination along one transect. Specific vertical boundary samples were not obtained at three locations. At each of these locations (CS01, CS02, and CS04), TPH-DRO was detected above the PAL to a depth of approximately $3 \mathrm{ft}$ bgs. These specific locations were not further evaluated during the CAU 322 CAI. However, vertical boundary was demonstrated at other nearby locations (Table A.4-8 and Figure A.4-4).

\section{A.4.2.5.6 Gamma-Emitting Isotopes}

Analytical results for gamma-emitting radionuclides in soil samples collected at CAS 03-25-03 that exceeded MDCs are presented in Table A.4-9. No gamma-emitting radionuclides were detected above PALs. 
Table A.4-8

Vertical Bounding of TPH-DRO at Area B

(Page 1 of 2)

\begin{tabular}{|c|c|c|c|c|}
\hline Borehole & Sample Number & $\begin{array}{c}\text { Depth } \\
\text { (ft bgs) }\end{array}$ & $\begin{array}{c}\text { TPH-DRO } \\
\text { (mg/kg) }\end{array}$ & Comments \\
\hline \multirow{6}{*}{ B08 } & 322B012 & $0-0.5$ & $72(\mathrm{H}, \mathrm{M})$ & \multirow{6}{*}{ Vertical bounding sample obtained } \\
\hline & 322B053 & $2-3$ & $170(H, M)$ & \\
\hline & 322B072 & $4-5$ & ND & \\
\hline & $\begin{array}{c}\text { 322B073 } \\
\text { (Duplicate of 322B072) }\end{array}$ & $4-5$ & ND & \\
\hline & 322B054 & $14-15$ & ND & \\
\hline & $\begin{array}{c}\text { 322B055 } \\
\text { (Duplicate of 322B054) } \\
\end{array}$ & $14-15$ & ND & \\
\hline \multirow{6}{*}{ B14 \& B18 } & 322B019 & $0-0.5$ & $\overline{\mathrm{ND}}$ & \multirow{6}{*}{$\begin{array}{l}\text { Vertical bounding sample obtained } \\
\text { Borehole B14 was completed at } 15 \mathrm{ft} \text { bgs. } \\
\text { When sample results were returned and } \\
\text { indicated contamination above the PAL at } \\
15 \mathrm{ft} \text { bgs, borehole B18 was drilled } \\
\text { alongside B14 (approximately } 6 \mathrm{ft} \text { away) as } \\
\text { a continuation of sampling at this location. }\end{array}$} \\
\hline & 322B042 & $2-3$ & ND & \\
\hline & 322B043 & $14-15$ & $300(\mathrm{H}, \mathrm{Y})$ & \\
\hline & 322B056 & $15-16$ & ND & \\
\hline & 322B057 & $20-21$ & ND & \\
\hline & 322B058 & $25-26$ & ND & \\
\hline \multirow{6}{*}{ B15 \& CS06 } & 322B020 & $\overline{0-0.5}$ & 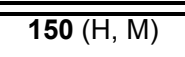 & \multirow{6}{*}{$\begin{array}{l}\text { Vertical bounding sample obtained } \\
\text { Borehole CS06 and Borehole B15 were } \\
\text { drilled within approximately } 10 \mathrm{ft} \text { of each } \\
\text { other. }\end{array}$} \\
\hline & CS0601 & $1.5-2.5$ & $3,800(J)$ & \\
\hline & CS0699 & $1.5-2.5$ & $10,000(\mathrm{~J})$ & \\
\hline & 322B044 & $2-3$ & $4,000(Y)$ & \\
\hline & 322B045 & $10-11$ & ND & \\
\hline & 322B046 & $14-15$ & ND & \\
\hline \multirow{2}{*}{ B17 } & $\overline{~ 322 \mathrm{~B} 062}$ & $2-3$ & $1,500(\mathrm{H}, \mathrm{M})$ & \multirow{2}{*}{ Vertical bounding sample obtained } \\
\hline & 322B063 & $7-8$ & ND & \\
\hline \multirow{3}{*}{ CS01 } & CS0100 & $\overline{0-0.5}$ & $\overline{100}$ & \multirow{3}{*}{$\begin{array}{l}\text { Samples were collected at this location } \\
\text { during investigation of CAU } 34 \text {. No specific } \\
\text { vertical bounding samples were collected for } \\
\text { this borehole. However, all locations } \\
\text { sampled during the } 322 \text { CAl were bounded. }\end{array}$} \\
\hline & CS0101 & $0.5-1.5$ & 540 & \\
\hline & CS0102 & $1.5-2.5$ & 510 & \\
\hline \multirow[b]{2}{*}{ CS02 } & CS0200 & $0-0.5$ & 91 & \multirow{2}{*}{$\begin{array}{l}\text { Samples were collected at this location } \\
\text { during investigation of CAU } 34 \text {. No specific } \\
\text { vertical bounding samples were collected for } \\
\text { this borehole. However, all locations } \\
\text { sampled during the } 322 \text { CAl were bounded. }\end{array}$} \\
\hline & CS0202 & $1.5-2.5$ & 160 & \\
\hline \multirow{8}{*}{ CS03 \& B12 } & $\overline{\mathrm{CS} 0300}$ & $\overline{0-0.5}$ & $\overline{100}$ & \multirow{8}{*}{$\begin{array}{l}\text { Vertical bounding sample obtained } \\
\text { Boreholes CS03 and B12 were drilled within } \\
\text { approximately } 10 \mathrm{ft} \text { of each other. }\end{array}$} \\
\hline & 322B016 & $0-0.5$ & ND & \\
\hline & 322B017 & $0-0.5$ & ND & \\
\hline & CS0301 & $0.5-1.5$ & 93 & \\
\hline & CS0302 & $1.5-2.5$ & $11,000(\mathrm{~J})$ & \\
\hline & 322B049 & $2-3$ & ND & \\
\hline & CS0306 & $6-7$ & $23,000(\mathrm{~J})$ & \\
\hline & 322B050 & $14-15$ & ND & \\
\hline
\end{tabular}




\section{Table A.4-8 \\ Vertical Bounding of TPH-DRO at Area B}

(Page 2 of 2)

\begin{tabular}{|c|c|c|c|c|}
\hline Borehole & Sample Number & $\begin{array}{c}\text { Depth } \\
\text { (ft bgs) }\end{array}$ & $\begin{array}{c}\text { TPH-DRO } \\
\text { (mg/kg) }\end{array}$ & Comments \\
\hline \multirow[b]{2}{*}{ CSO4 } & $\overline{\overline{C S} 0401}$ & $\overline{1-2}$ & $\overline{\overline{60}}$ & \multirow{2}{*}{$\begin{array}{l}\text { Samples were collected at this location } \\
\text { during investigation of CAU } 34 \text {. No specific } \\
\text { vertical bounding samples were collected for } \\
\text { this borehole. However, all locations } \\
\text { sampled during the } 322 \text { CAl were bounded. }\end{array}$} \\
\hline & CS0402 & $2-3$ & 260 & \\
\hline
\end{tabular}

ND $=$ Not detected above MRLs

$\mathrm{J}=$ Estimated value; qualifier added to laboratory data, record accepted; surrogates diluted out

$\mathrm{H}=$ The fuel pattern was in the heavier end of the retention time window for the analyte of interest

$M=A$ pattern resembling motor oil was detected

$\mathrm{Y}=$ Multipeak chromatogram does not match target analyte

\section{A.4.2.5.7 Strontium-90}

Analytical results for strontium ( $\mathrm{Sr}$ )-90 in soil samples collected at CAS 03-25-03 did not exceed the MDCs or PALs.

\section{A.4.2.5.8 Plutonium}

Analytical results for plutonium in soil samples collected at CAS 03-25-03, that exceeded MDCs are presented in Table A.4-10. Plutonium was detected above the PAL in soil sample $322 \mathrm{~B} 017$ collected at the surface at location B12 at Site B on the east side of the mud plant. The plutonium was likely present at this location due to fallout from atmospheric testing at the NTS; therefore, it is not a COC for this CAS. However, as a best management practice to mitigate potential personnel exposures the impacted soil (less than $1 \mathrm{ft}^{3}$ ) was removed and placed in a drum for disposal. A concrete pad was found immediately under the location where the soil was removed. A swipe sample was collected and analyzed in the field from the pad. Results of this sample indicated that the concrete was below the unrestricted release criteria. Three step out samples around sample location B12 (sample locations B23, B24, and B25) also confirm that the contamination had been removed.

\section{A.4.2.5.9 Uranium}

Analytical results for uranium in soil samples collected at CAS 03-25-03 that exceeded MDCs are presented in Table A.4-10. Uranium was not detected above the PALs. 


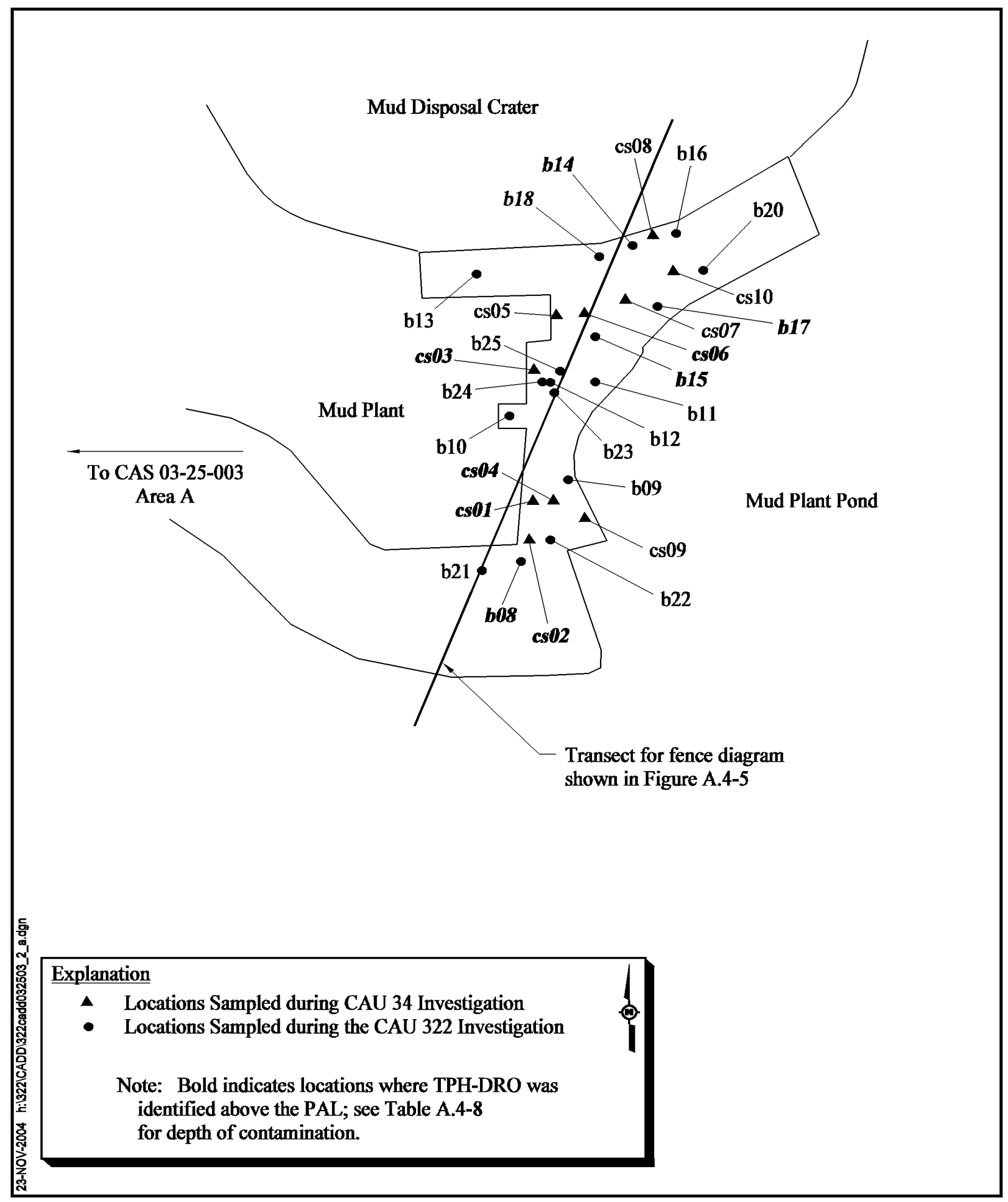

Figure A.4-4

Plan View Plot of TPH-DRO Hits above PALs at CAS 03-25-03, AST Release, Site B (East Side of Mud Plant) 


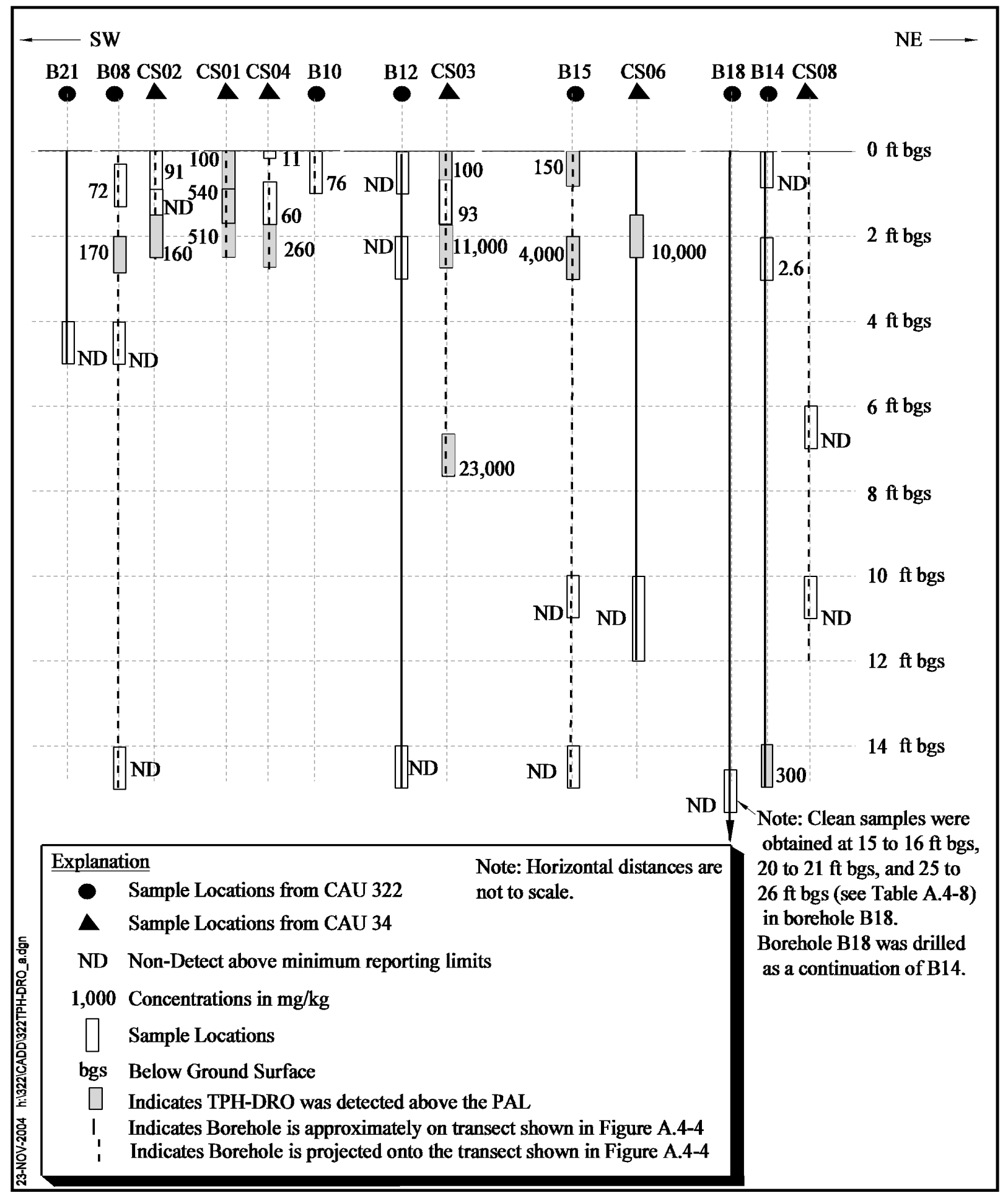

Figure A.4-5

Vertical Cross Section of TPH-DRO Concentrations at CAS 03-25-03, AST Release, Site B (East Side of Mud Plant) 
Table A.4-9

Soil Sample Results for Gamma-Emitting Radionuclides Detected Above Minimum Reporting Limits at CAS 03-25-03, Mud Plant AST Diesel Release (Page 1 of 2)

\begin{tabular}{|c|c|c|c|c|c|c|c|c|c|c|c|c|c|c|}
\hline \multirow[b]{2}{*}{$\begin{array}{c}\text { Sample } \\
\text { Location }\end{array}$} & \multirow[b]{2}{*}{$\begin{array}{l}\text { Sample } \\
\text { Number }\end{array}$} & \multirow{3}{*}{$\begin{array}{c}\text { Depth } \\
\text { (ft bgs) }\end{array}$} & \multicolumn{12}{|c|}{ Contaminants of Potential Concern (pCi/g) } \\
\hline & & & \multicolumn{2}{|c|}{ 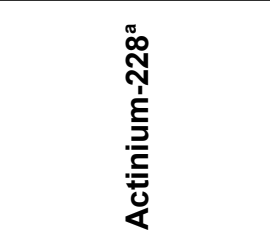 } & 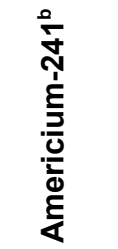 & \multicolumn{2}{|c|}{ 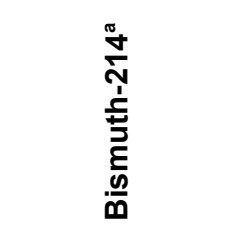 } & 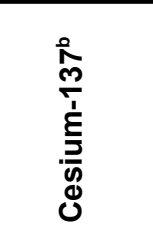 & \multicolumn{2}{|c|}{ 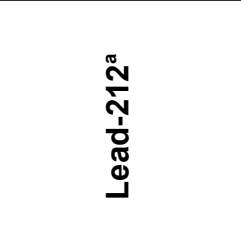 } & \multicolumn{2}{|c|}{ 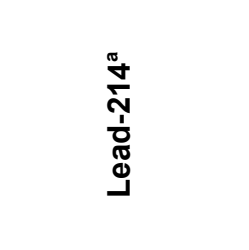 } & \multicolumn{2}{|c|}{ 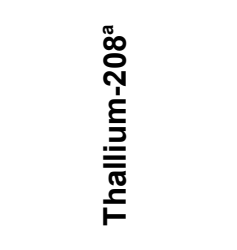 } \\
\hline \multicolumn{2}{|c|}{ Preliminary Action Levels } & & 5 & 15 & \multirow{2}{*}{7.62} & 5 & 15 & \multirow{2}{*}{7.3} & 5 & 15 & 5 & 15 & 5 & 15 \\
\hline \multicolumn{3}{|c|}{ Depth bgs (cm) } & $<15$ & $>15$ & & $<15$ & $>15$ & & $<15$ & $>15$ & $<15$ & $>15$ & $<15$ & $>15$ \\
\hline$\overline{\mathrm{B} 01}$ & 322B007 & $0-0.5$ & $1.98(\mathrm{G})$ & $\overline{\mathrm{NA}}$ & $\overline{---}$ & $1.04(\mathrm{G})$ & $\overline{\mathrm{NA}}$ & $\overline{---}$ & $2.05(\mathrm{~J})$ & $\overline{\mathrm{NA}}$ & $\overline{1.25(\mathrm{~J})}$ & $\overline{\mathrm{NA}}$ & $0.61(G)$ & $\overline{\mathrm{NA}}$ \\
\hline B02 & 322B008 & $0-0.5$ & $1.72(\mathrm{G})$ & NA & -- & $0.76(\mathrm{G})$ & NA & -- & $2.08(\mathrm{~J})$ & NA & $1.06(\mathrm{~J})$ & NA & $0.65(\mathrm{G})$ & NA \\
\hline B03 & 322B009 & $0-0.5$ & $1.89(\mathrm{G})$ & NA & $\overline{--}$ & $1.22(\mathrm{G})$ & NA & $\overline{--}$ & $2.04(\mathrm{~J})$ & NA & $1.17(\mathrm{~J})$ & NA & $0.65(\mathrm{G})$ & $\mathrm{NA}$ \\
\hline B04 & 322B010 & $0-0.5$ & $1.52(\mathrm{G})$ & NA & -- & $1.06(\mathrm{G})$ & NA & -- & $2.08(\mathrm{~J})$ & $\mathrm{NA}$ & $1.15(\mathrm{~J})$ & NA & $0.56(\mathrm{G})$ & NA \\
\hline B05 & 322B011 & $0-0.5$ & $2.03(\mathrm{G})$ & NA & -- & $0.77(\mathrm{G})$ & NA & -- & $2.22(\mathrm{~J})$ & NA & $1.17(\mathrm{~J})$ & NA & $0.56(\mathrm{G})$ & $\mathrm{NA}$ \\
\hline B06 & 322B001 & $0-0.5$ & $1.4(\mathrm{G})$ & NA & -- & $0.89(\mathrm{G})$ & NA & -- & $1.56(\mathrm{~J})$ & NA & $1(\mathrm{~J})$ & NA & $0.48(\mathrm{G})$ & $\mathrm{NA}$ \\
\hline B08 & 322B012 & $0-0.5$ & $1.59(\mathrm{G})$ & NA & $\overline{--}$ & $1.01(\mathrm{G})$ & NA & -- & $1.69(\mathrm{~J})$ & NA & $1.23(\mathrm{~J})$ & NA & $0.56(\mathrm{G})$ & $\mathrm{NA}$ \\
\hline B09 & 322B013 & $0-0.5$ & $1.33(\mathrm{G})$ & NA & -- & $1.13(\mathrm{G})$ & NA & -- & $1.57(\mathrm{~J})$ & NA & $1.19(\mathrm{~J})$ & NA & $0.58(\mathrm{G})$ & NA \\
\hline B10 & 322B014 & $0-0.5$ & $1.46(\mathrm{G})$ & NA & $0.78(\mathrm{~J})$ & $1.14(\mathrm{G})$ & NA & -- & $1.86(\mathrm{~J})$ & NA & $1.33(\mathrm{~J})$ & NA & $0.55(\mathrm{G})$ & $\mathrm{NA}$ \\
\hline B11 & 322B015 & $0-0.5$ & $1.64(\mathrm{G})$ & NA & -- & $1.12(\mathrm{G})$ & NA & -- & $1.83(\mathrm{~J})$ & NA & $1.2(\mathrm{~J})$ & NA & $0.56(\mathrm{G})$ & NA \\
\hline \multirow{2}{*}{ B12 } & 322B016 & $0-0.5$ & $1.69(\mathrm{G})$ & NA & -- & $0.9(\mathrm{G})$ & NA & $0.3(\mathrm{G}, \mathrm{LT})$ & $2.1(\mathrm{~J})$ & NA & $0.97(\mathrm{~J})$ & NA & $0.6(G)$ & NA \\
\hline & 322B017 & $0-0.5$ & $1.71(\mathrm{G})$ & NA & -- & $1.07(\mathrm{G})$ & NA & - & $2.09(\mathrm{~J})$ & NA & $1.03(\mathrm{~J})$ & NA & $0.74(G)$ & NA \\
\hline B13 & 322B018 & $0-0.5$ & $1.47(\mathrm{G})$ & NA & -- & $0.93(\mathrm{G})$ & NA & -- & $1.82(\mathrm{~J})$ & NA & $1.15(\mathrm{~J})$ & NA & $0.53(\mathrm{G})$ & $\mathrm{NA}$ \\
\hline B14 & 322B019 & $0-0.5$ & $1.37(\mathrm{G})$ & NA & -- & $0.94(\mathrm{G})$ & NA & $\overline{--}$ & $1.91(\mathrm{~J})$ & NA & $1.27(\mathrm{~J})$ & NA & $0.5(\mathrm{G})$ & NA \\
\hline
\end{tabular}


Table A.4-9

Soil Sample Results for Gamma-Emitting Radionuclides Detected Above Minimum Reporting Limits at CAS 03-25-03, Mud Plant AST Diesel Release (Page 2 of 2)

\begin{tabular}{|c|c|c|c|c|c|c|c|c|c|c|c|c|c|c|}
\hline \multirow[b]{2}{*}{$\begin{array}{l}\text { Sample } \\
\text { Location }\end{array}$} & \multirow[b]{2}{*}{$\begin{array}{l}\text { Sample } \\
\text { Number }\end{array}$} & \multirow[b]{2}{*}{$\begin{array}{c}\text { Depth } \\
\text { (ft bgs) }\end{array}$} & \multicolumn{12}{|c|}{ Contaminants of Potential Concern (pCi/g) } \\
\hline & & & \multicolumn{2}{|c|}{ 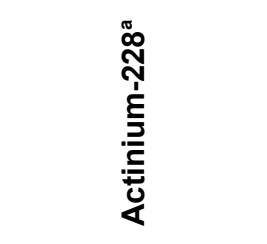 } & 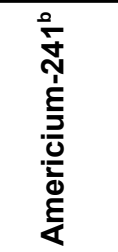 & \multicolumn{2}{|c|}{ 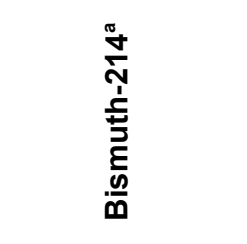 } & 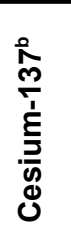 & \multicolumn{2}{|c|}{ 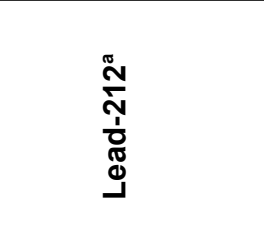 } & \multicolumn{2}{|c|}{ 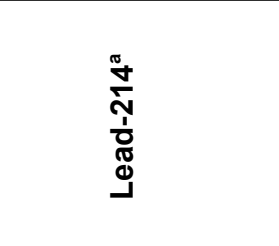 } & \multicolumn{2}{|c|}{ 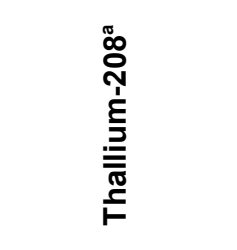 } \\
\hline \multicolumn{3}{|c|}{ Preliminary Action Levels } & 5 & 15 & \multirow{2}{*}{7.62} & 5 & 15 & \multirow{2}{*}{7.3} & 5 & 15 & 5 & 15 & 5 & 15 \\
\hline \multicolumn{3}{|c|}{ Depth bgs (cm) } & $<15$ & $>15$ & & $<15$ & $>15$ & & $<15$ & $>15$ & $<15$ & $>15$ & $<15$ & $>15$ \\
\hline B15 & 322B020 & $0-0.5$ & $1.82(\mathrm{G})$ & $\overline{\mathrm{NA}}$ & $0.48(\mathrm{~J})$ & $1.23(\mathrm{G})$ & $\overline{\mathrm{NA}}$ & $\overline{---}$ & $2.08(\mathrm{~J})$ & $\overline{\mathrm{NA}}$ & $\overline{1.05(\mathrm{~J})}$ & $\overline{\mathrm{NA}}$ & $0.69(\mathrm{G})$ & $\overline{\mathrm{NA}}$ \\
\hline B19 & 322B064 & $0-1$ & NA & 1.31 & - & NA & 0.86 & 0.98 & NA & $1.92(\mathrm{~J})$ & NA & $0.77(\mathrm{~J})$ & NA & 0.39 \\
\hline
\end{tabular}

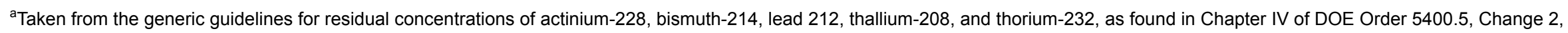

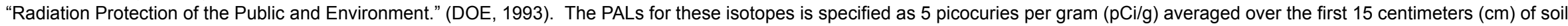

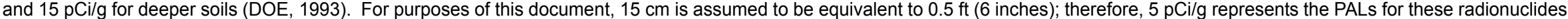
in the surface soil ( 0 to $0.5 \mathrm{ft}$ depth).

${ }^{\mathrm{b}}$ Taken from the construction, commercial, industrial land use scenario in Table 2.1 of the NCRP Report No. 129, Recommended Screening Limits for Contaminated Surface Soil and Review Factors Relevant to Site-Specific Studies (NCRP, 1999). The values provided in this source document were scaled to a 15-mrem/yr. dose.

$\mathrm{ft}$ bgs $=$ Feet below ground surface

$\mathrm{cm}=$ Centimeter

$\mathrm{pCi} / \mathrm{g}=$ Picocuries per gram

-- = Not detected above minimum reporting limits

$>=$ Greater than

$<=$ Less than

$\mathrm{G}=$ Sample density differs by more than 15 percent of laboratory control sample density.

$\mathrm{J}=$ Estimated value. Qualifier added to laboratory data; record accepted. Sample does not meet counting geometry requirements.

$\mathrm{LT}=$ Result is less than the requested minimum detectable concentration, greater than the sample-specific minimum detectable concentration

$\mathrm{NA}=$ Not applicable 
Table A.4-10

Soil Sample Results for Isotopes Detected Above Minimum Reporting Limits at CAS 03-25-03, Mud Plant AST Diesel Release

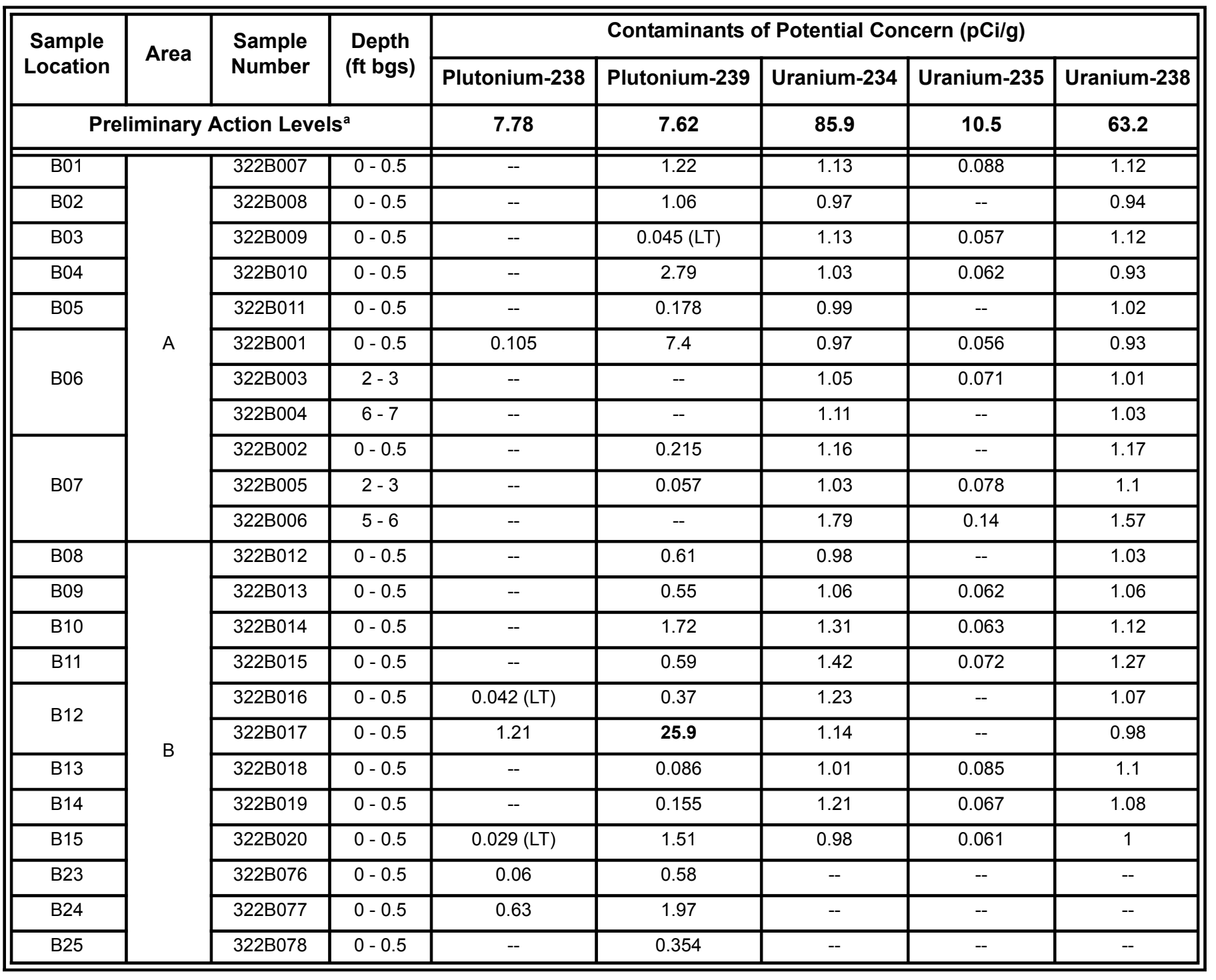

${ }^{a}$ Taken from the construction, commercial, industrial land use scenario in Table 2.1 of the NCRP Report No. 129 Recommended Screening Limits for Contaminated Surface Soil and Review Factors Relevant to Site-Specific Studies (NCRP, 1999). The values provided in this source document were scaled to a $15-\mathrm{mrem} / \mathrm{yr}$ dose.

$\mathrm{ft}$ bgs $=$ Feet below ground surface $\mathrm{pCi} / \mathrm{g}=$ Picocuries per gram

$\mathrm{LT}=$ Result is less than the requested minimum detectable concentration, greater than the sample-specific minimum detectable concentration.

$--=$ Not detected above minimum reporting limits 


\section{A.4.2.6 Contaminants of Concern}

In Area A, the only COC identified was TPH-DRO; however, all soil contaminated with TPH-DRO at Area A was removed and containerized for waste disposal. Verification samples indicated no additional contamination remained. Therefore, there are no COCs remaining a Area A.

In Area B, Pu-239 was identified above PALs. Data obtained from sample 322B017 collected in Area B of this CAS indicated Pu-239 above the PAL. Although the Pu-239 is not believed to be present due to activities associated with CAS 03-25-03 the contaminated soil was removed and drummed for disposal as a best management practice to mitigate potential personnel exposures.

Also in Area B TPH-DRO was identified above the PAL in several locations and is considered a COC.

\section{A.4.3 Nature and Extent of Contamination}

In Area A, no contamination above PALs remains.

In Area B, TPH-DRO contamination was identified at several locations and at varying depths. There was no identifiable pattern or plume to the presence of TPH-DRO contamination that would lend itself to identify a point source for the contamination observed. The TPH-DRO contamination pattern (or lack thereof) supports the CSM which identifies the possibility that TPH-DRO contamination is the result of random spills, leaks, and overflows associated with mobile equipment (e.g., generators), mobile vehicles (e.g., trucks, front-end loaders), or fixed equipment (e.g., pumps) that required diesel fuel for power generation. The lateral extent of contamination was identified by step-out sampling at locations B16 and B20 to the northwest, B13 to the northeast, B21 to the southwest, and B22 to the southeast. The contaminated area is also bordered by CAU 34, CAS 03-09-06, Mud Disposal Crater to the north; the Mud Plant structure to the west; and CAU 34, CAS 03-47-02, Mud Plant Pond to the east. Corrective actions sites 03-09-06 and 03-47-02 were closed in place with use restrictions due to TPH contamination. The contaminated area encompasses approximately 7,600 $\mathrm{ft}^{2}$. The vertical extent of contamination was variable (Table A.4-8); however, the deepest contamination identified was confined to $10 \mathrm{ft}$ bgs. 


\section{A.4.4 Revised Conceptual Site Model}

No variations in the CSM were identified; however, some additional clarification is provided.

At Area A there was no indication of TPH-DRO contamination of the type described in the historical documents referenced in the CAIP. These documents indicated TPH-DRO contamination remained after the 1992 remediation activities. Investigation activities were designed to identify the presence and location of the residual contamination. None was found, with the exception of one surface soil sample (location B04) and one 2 to $3 \mathrm{ft}$ bgs interval (location B01). The surface soil sample TPH-DRO contamination at location B04 may be due to the presence of oil-based paint chips observed at the sample location. Sampling beneath the surface soil revealed no TPH-DRO contamination, and a confirmation sample taken beneath the removed and containerized soil was nondetect for TPH-DRO. The TPH-DRO contamination at the 2 to $3 \mathrm{ft}$ bgs interval at location B01 was removed and confirmation samples indicate no TPH-DRO contamination remained.

The CSM developed in the CAIP for Area B offered several potential sources of TPH-DRO contamination including contaminant transport along a preferred pathway such as utility lines from Area A. However, investigation results indicate the TPH-DRO contamination is more likely the result of random spills, leaks, and overflows associated with mobile equipment (e.g., generators), mobile vehicles (e.g., trucks, front-end loaders), or fixed equipment (e.g., pumps) that required diesel fuel for power generation. The appearance of TPH-DRO at different locations and depths may have been enhanced by grading, removal of soil, and/or placement of fill during operations at the mud plant and the use of diesel and/or oil for dust suppression. 


\section{A.5.0 CAS 03-20-05, Injection Well}

Corrective Action Site 03-20-05, Injection Well, is located in Area 3 and is associated with the LLNL BOP Shop.

The CSM for CAS 03-20-05 included potential soil contamination originating from the holding/cleaning tanks, the injection well, the line running from the BOP Shop to the injection well, and runoff from the BOP Shop floor resulting from possible overfills of the holding/cleaning tanks. The CAIP called for the collection of soil samples commensurate with the depths of possible sources of contamination. Because the assumed depth of the holding/cleaning tanks within the BOP Shop was 30 to $50 \mathrm{ft}$ bgs, samples collected around the holding/cleaning tanks were taken to $100 \mathrm{ft}$ bgs. Because the depth of the injection well sump was estimated to be between 60 and $100 \mathrm{ft}$ bgs, the soil samples taken around the injection well were taken to approximately $120 \mathrm{ft}$ bgs. The soil samples collected just off the BOP Shop floor were taken to a depth of approximately $6 \mathrm{ft}$ bgs.

\section{A.5.1 Corrective Action Investigation}

A total of 106 samples were collected at CAS 03-20-05. Eleven of the samples collected were liquids from the holding/cleaning tanks and associated sumps and the injection well sump. Two of the liquid samples were classified by the laboratory as oil samples. Soil samples were collected at locations identified in the CAU 322 CAIP. The liquid and soil samples were analyzed for the parameters listed in Table A.5-1. The soil sample locations are shown in Figure A.5-1 and the sample locations from tanks and sumps are shown in Figure A.5-2. The specific CAI activities conducted to satisfy the CAIP requirements at CAS 03-20-05 are described in the following sections.

\section{A.5.1.1 Deviations}

There were no deviations to the CAIP requirements at this CAS.

\section{A.5.2 Investigation Results}

The following sections provide descriptions of the CAS-specific activities conducted to complete investigation activities as outlined in the CAIP. Investigation activities included the visual inspection of the CAS, sampling of the liquid contents of the holding/cleaning tanks and associated sumps, the 
Table A.5-1

Samples Collected at CAS 03-20-05, Injection Well (Page 1 of 5 )

\begin{tabular}{|c|c|c|c|c|c|}
\hline $\begin{array}{c}\text { Sample } \\
\text { Location }\end{array}$ & $\begin{array}{l}\text { Sample } \\
\text { Number }\end{array}$ & $\begin{array}{l}\text { Depth } \\
\text { (ft bgs) }\end{array}$ & $\begin{array}{l}\text { Sample } \\
\text { Matrix }\end{array}$ & Purpose & Analyses \\
\hline \multirow{3}{*}{ C01 } & 322C001 & $\overline{0-0.5}$ & $\overline{\overline{\text { Soil }}}$ & $\overline{\mathrm{SC}}$ & $\overline{\text { Sets } 1,2,3 \text {, and } 6}$ \\
\hline & $322 \mathrm{C002}$ & $2-3$ & Soil & $\overline{S C}$ & Sets $1,2,3$, and 6 \\
\hline & $322 \mathrm{C} 003$ & $4-5$ & Soil & $\mathrm{SC}$ & Sets $1,2,3$, and 6 \\
\hline \multirow{3}{*}{$\mathrm{C02}$} & $322 \mathrm{C} 004$ & $0-0.5$ & Soil & SC & Sets $1,2,3$, and 6 \\
\hline & $322 \mathrm{C005}$ & $2-3$ & Soil & $\mathrm{SC}$ & Sets $1,2,3$, and 6 \\
\hline & $322 \mathrm{C006}$ & $5-6$ & Soil & $\mathrm{SC}$ & Sets $1,2,3$, and 6 \\
\hline \multirow{3}{*}{$\mathrm{C03}$} & $322 \mathrm{C007}$ & $0-0.5$ & Soil & $\overline{S C}$ & Sets $1,2,3$, and 6 \\
\hline & $322 \mathrm{C008}$ & $2-3$ & Soil & $\overline{S C}$ & Sets $1,2,3$, and 6 \\
\hline & $322 C 009$ & $5-6$ & Soil & SC & Sets $1,2,3$, and 6 \\
\hline \multirow{4}{*}{$\mathrm{CO4}$} & $322 \mathrm{C} 010$ & $0-0.5$ & Soil & $\overline{S C}$ & Sets $1,2,3$, and 6 \\
\hline & 322C011 & $4-5$ & Soil & SC, MS/MSD & Sets $1,2,3$, and 6 \\
\hline & $322 \mathrm{C} 012$ & $7-8$ & Soil & $\mathrm{SC}$ & Sets $1,2,3$, and 6 \\
\hline & $322 \mathrm{C} 013$ & $7-8$ & Soil & $\begin{array}{c}\text { Field Duplicate } \\
\text { of } 322 \mathrm{C} 012\end{array}$ & Sets $1,2,3$, and 6 \\
\hline \multirow{3}{*}{$\mathrm{C} 05$} & $322 \mathrm{C} 013 \mathrm{~A}$ & $0-0.5$ & Soil & $\mathrm{SC}$ & Sets $1,2,3$, and 6 \\
\hline & $322 \mathrm{C} 014$ & $2-3$ & Soil & $\mathrm{SC}$ & Sets $1,2,3$, and 6 \\
\hline & $322 \mathrm{C} 015$ & $5-6$ & Soil & $\overline{S C}$ & Sets $1,2,3$, and 6 \\
\hline \multirow{3}{*}{$\mathrm{C} 06$} & $322 \mathrm{C} 016$ & $0-1$ & Soil & SC & Sets 1 through 7 \\
\hline & $322 \mathrm{C017}$ & $3-4$ & Soil & $\overline{S C}$ & Sets 1 through 7 \\
\hline & $322 \mathrm{C} 018$ & $5-6$ & Soil & $\overline{S C}$ & Sets 1 through 7 \\
\hline \multirow{6}{*}{$\mathrm{C} 07$} & 322C019 & $0-2$ & Soil & $\mathrm{SC}$ & Sets 1 through 7 \\
\hline & $322 \mathrm{C} 020$ & $3-4$ & Soil & SC & Sets 1 through 7 \\
\hline & $322 \mathrm{C} 021$ & $5-6$ & Soil & $\mathrm{SC}$ & Sets 1 through 7 \\
\hline & 322C091 & $14-15$ & Soil & SC & Set 8 , SVOCs \\
\hline & 322C092 & $19-20$ & Soil & $\mathrm{SC}$ & Set 8, SVOCs \\
\hline & $322 \mathrm{C} 093$ & $24-25$ & Soil & Sc & Set 8 , SVOCs \\
\hline \multirow[b]{2}{*}{ HT-1 } & $322 \mathrm{C} 023$ & NA & Liquid & WC & $\begin{array}{l}\text { TPH-DRO, PCBs, } \\
\text { Tritium, Total SVOCs }\end{array}$ \\
\hline & $322 \mathrm{C} 023 \mathrm{~A}$ & NA & Liquid & WC & $\begin{array}{l}\text { Sets } 2,3,4, \text { Total } \\
\text { VOCs, TPH-GRO, } \\
\text { RCRA Metals, Be }\end{array}$ \\
\hline \multirow{3}{*}{ HT-2 } & $322 C 039$ & NA & Liquid & WC & Sets $1,2,3,4$ and $6^{a}$ \\
\hline & $322 \mathrm{C} 039 \mathrm{~A}$ & NA & Liquid & WC & Tritium \\
\hline & $322 \mathrm{C} 040$ & NA & Liquid & $\begin{array}{c}\text { Field Duplicate } \\
\text { of } 322 \mathrm{C} 039\end{array}$ & Sets 1 through 6 \\
\hline \multirow[b]{2}{*}{ HT-3 } & $322 \mathrm{C} 022$ & NA & Liquid & WC & $\begin{array}{l}\text { TPH-DRO, PCBs, } \\
\text { Tritium, Total SVOCs }\end{array}$ \\
\hline & $322 \mathrm{C} 022 \mathrm{~A}$ & NA & Liquid & WC & $\begin{array}{l}\text { Sets } 2,3,4, \text { Total } \\
\text { VOCs, TPH-GRO, } \\
\text { RCRA Metals, Be }\end{array}$ \\
\hline
\end{tabular}


Table A.5-1

Samples Collected at CAS 03-20-05, Injection Well (Page 2 of 5 )

\begin{tabular}{|c|c|c|c|c|c|}
\hline $\begin{array}{c}\text { Sample } \\
\text { Location }\end{array}$ & $\begin{array}{l}\text { Sample } \\
\text { Number }\end{array}$ & $\begin{array}{c}\text { Depth } \\
\text { (ft bgs) }\end{array}$ & $\begin{array}{l}\text { Sample } \\
\text { Matrix }\end{array}$ & Purpose & Analyses \\
\hline \multirow{14}{*}{$\mathrm{C} 08$} & $\overline{322 \mathrm{C} 024}$ & $\overline{0-2}$ & 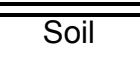 & $\overline{\mathrm{SC}}$ & Sets 1 through 6 \\
\hline & $322 \mathrm{C} 025$ & $9-10$ & Soil & $\mathrm{SC}$ & Sets 1 through 6 \\
\hline & $322 \mathrm{C} 026$ & $20-21$ & Soil & SC, MS/MSD & Sets 1 through 6 \\
\hline & $322 \mathrm{C} 027$ & $30-31$ & Soil & SC & Sets 1 through 6 \\
\hline & $322 \mathrm{C} 028$ & $40-41$ & Soil & $\mathrm{SC}$ & Sets 1 through 6 \\
\hline & $322 C 029$ & $50-51$ & Soil & SC & Sets 1 through 6 \\
\hline & $322 \mathrm{C0} 030$ & $60-61$ & Soil & SC & Sets 1 through 6 \\
\hline & $322 \mathrm{C} 031$ & $70-71$ & Soil & SC & Sets 1 through 6 \\
\hline & $322 \mathrm{C} 032$ & $80-81$ & Soil & SC & Sets 1 through 6 \\
\hline & $322 \mathrm{C} 033$ & $91-92$ & Soil & $\overline{S C}$ & Sets 1 through 6 \\
\hline & $322 \mathrm{C} 034$ & $100-101$ & Soil & $\overline{S C}$ & Sets 1 through 6 \\
\hline & $322 \mathrm{C} 035$ & $111-112$ & Soil & SC & Sets 1 through 6 \\
\hline & $322 \mathrm{C} 036$ & $122-123$ & Soil & $\overline{S C}$ & Sets 1 through 6 \\
\hline & $322 \mathrm{C} 105$ & $0.5-1.5$ & Soil & SC & Iso-Pu \\
\hline \multirow{16}{*}{ Co9 } & $322 \mathrm{C} 037$ & $0-0.5$ & Soil & $\mathrm{SC}$ & Sets 1 through 6 \\
\hline & $322 \mathrm{C} 038$ & $0-0.5$ & Soil & $\begin{array}{c}\text { Field Duplicate } \\
\text { of } 322 \mathrm{C} 037\end{array}$ & Sets 1 through 6 \\
\hline & $322 \mathrm{C} 042$ & $10-11$ & Soil & SC & Sets 1 through 6 \\
\hline & $322 \mathrm{C} 043$ & $20-21$ & Soil & SC & Sets 1 through 6 \\
\hline & $322 \mathrm{C} 044$ & $30-31$ & Soil & SC & Sets 1 through 6 \\
\hline & $322 \mathrm{C} 045$ & $40-41$ & Soil & SC & Sets 1 through 6 \\
\hline & $322 \mathrm{C} 046$ & $51-52$ & Soil & $\overline{S C}$ & Sets 1 through 6 \\
\hline & $322 \mathrm{C} 047$ & $60-61$ & Soil & SC, MS/MSD & Sets 1 through 6 \\
\hline & $322 \mathrm{C} 048$ & $70-71$ & Soil & SC & Sets 1 through 6 \\
\hline & 322C049 & $81-82$ & Soil & SC & Sets 1 through 6 \\
\hline & $322 \mathrm{C} 050$ & $92-93$ & Soil & SC & Sets 1 through 6 \\
\hline & $322 \mathrm{C} 051$ & $101-102$ & Soil & SC & Sets 1 through 6 \\
\hline & $322 \mathrm{C} 052$ & $111-112$ & Soil & $\overline{S C}$ & Sets 1 through 6 \\
\hline & $322 \mathrm{C} 053$ & $121-122$ & Soil & SC & Sets 1 through 6 \\
\hline & $322 C 089$ & $1-2$ & Soil & SC & Iso-Pu \\
\hline & $322 \mathrm{C} 103$ & $0.5-1.5$ & Soil & $\overline{S C}$ & Iso-Pu \\
\hline \multirow{2}{*}{ HT-1 sump } & $322 \mathrm{C055O}$ & $\mathrm{NA}$ & Oil & WC & Sets 1 through 6 \\
\hline & 322C055L & $\mathrm{NA}$ & Liquid & WC & Sets 1 through 6 \\
\hline \multirow{2}{*}{ HT-3 sump } & $322 \mathrm{C054O}$ & $\overline{N A}$ & Oil & WC & Sets 1 through 6 \\
\hline & 322C054L & $\mathrm{NA}$ & Liquid & WC & Sets 1 through 6 \\
\hline
\end{tabular}


Table A.5-1

Samples Collected at CAS 03-20-05, Injection Well (Page 3 of 5 )

\begin{tabular}{|c|c|c|c|c|c|}
\hline $\begin{array}{c}\text { Sample } \\
\text { Location }\end{array}$ & $\begin{array}{l}\text { Sample } \\
\text { Number }\end{array}$ & $\begin{array}{c}\text { Depth } \\
\text { (ft bgs) }\end{array}$ & $\begin{array}{l}\text { Sample } \\
\text { Matrix }\end{array}$ & Purpose & Analyses \\
\hline \multirow{12}{*}{$\mathrm{C} 10$} & 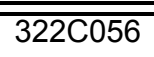 & $\overline{\overline{1-2}}$ & 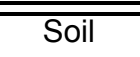 & $\overline{\mathrm{SC}}$ & $\overline{\text { Sets } 1 \text { through } 6}$ \\
\hline & $322 \mathrm{C057}$ & $10-11$ & Soil & $\mathrm{SC}$ & Sets 1 through 6 \\
\hline & $322 \mathrm{C} 058$ & $21-22$ & Soil & SC & Sets 1 through 6 \\
\hline & 322C059 & $30-31$ & Soil & SC & Sets 1 through 6 \\
\hline & $322 \mathrm{C060}$ & $41-42$ & Soil & SC & Sets 1 through 6 \\
\hline & $322 \mathrm{C} 061$ & $51-52$ & Soil & SC & Sets 1 through 6 \\
\hline & $322 \mathrm{C} 062$ & $60-61$ & Soil & $\overline{S C}$ & Sets 1 through 6 \\
\hline & $322 \mathrm{C} 063$ & $71-72$ & Soil & SC, MS/MSD & Sets 1 through 6 \\
\hline & $322 \mathrm{C} 064$ & $81-82$ & Soil & SC & Sets 1 through 6 \\
\hline & $322 \mathrm{C} 065$ & $81-82$ & Soil & $\begin{array}{c}\text { Field Duplicate } \\
\text { of } 322 \mathrm{C} 064\end{array}$ & Sets 1 through 6 \\
\hline & $322 \mathrm{C} 066$ & $91-92$ & Soil & SC & Sets 1 through 6 \\
\hline & $322 \mathrm{C} 067$ & $101-102$ & Soil & $\overline{S C}$ & Sets 1 through 6 \\
\hline \multirow{4}{*}{ C11 } & $322 \mathrm{C} 068$ & $0-1$ & Soil & SC & Sets $1,2,3,4$ and 6 \\
\hline & $322 C 069$ & $49-50$ & Soil & SC & Sets $1,2,3,4$ and 6 \\
\hline & $322 \mathrm{C} 070$ & $59-60$ & Soil & SC & Sets $1,2,3,4$ and 6 \\
\hline & $322 \mathrm{C} 071$ & $69-70$ & Soil & SC & Sets $1,2,3,4$ and 6 \\
\hline \multirow{4}{*}{$\mathrm{C} 12$} & $322 \mathrm{C} 072$ & $0-1$ & Soil & SC & Sets $1,2,3,4$ and 6 \\
\hline & $322 \mathrm{C} 073$ & $49-50$ & Soil & SC & Sets $1,2,3,4$ and 6 \\
\hline & $322 \mathrm{C} 074$ & $59-60$ & Soil & SC & Sets $1,2,3,4$ and 6 \\
\hline & $322 \mathrm{C} 075$ & $69-70$ & Soil & SC & Sets $1,2,3,4$ and 6 \\
\hline \multirow{3}{*}{$\mathrm{C} 13$} & $322 \mathrm{C} 076$ & $0-0.5$ & Soil & SC & Iso-Pu \\
\hline & $322 \mathrm{C} 077$ & $0-0.5$ & Soil & $\begin{array}{c}\text { Field Duplicate } \\
\text { of } 322 \mathrm{C} 076\end{array}$ & Iso-Pu \\
\hline & $322 \mathrm{C} 078$ & $1-2$ & Soil & SC & Iso-Pu \\
\hline \multirow{3}{*}{ C14 } & 322C079 & $0-0.5$ & Soil & SC & Iso-Pu \\
\hline & $322 \mathrm{C} 080$ & $1-2$ & Soil & SC & Iso-Pu \\
\hline & $322 \mathrm{C} 104$ & $0.5-1.5$ & Soil & SC & Iso-Pu \\
\hline \multirow{2}{*}{ C15 } & $322 \mathrm{C} 081$ & $0.5-1$ & Soil & SC & Iso-Pu \\
\hline & $322 \mathrm{C} 082$ & $1-2$ & Soil & SC & Iso-Pu \\
\hline \multirow{2}{*}{ C16 } & $322 \mathrm{C} 083$ & $0.5-1$ & Soil & SC & Iso-Pu \\
\hline & $322 \mathrm{C} 084$ & $1-2$ & Soil & $\overline{S C}$ & Iso-Pu \\
\hline \multirow{2}{*}{$\mathrm{C} 17$} & $322 \mathrm{C} 085$ & $0.5-1$ & Soil & SC & Iso-Pu \\
\hline & $322 \mathrm{C} 086$ & $1-2$ & Soil & SC & Iso-Pu \\
\hline \multirow{3}{*}{$\mathrm{C} 18$} & $322 \mathrm{C} 087$ & $0.5-1$ & Soil & SC & Iso-Pu \\
\hline & $322 \mathrm{C} 088$ & $1-2$ & Soil & SC & Iso-Pu \\
\hline & $322 \mathrm{C} 106$ & $0.5-1.5$ & Soil & $\overline{S C}$ & Iso-Pu \\
\hline
\end{tabular}


Table A.5-1

Samples Collected at CAS 03-20-05, Injection Well

(Page 4 of 5 )

\begin{tabular}{|c|c|c|c|c|c|}
\hline $\begin{array}{c}\text { Sample } \\
\text { Location }\end{array}$ & $\begin{array}{l}\text { Sample } \\
\text { Number }\end{array}$ & $\begin{array}{c}\text { Depth } \\
\text { (ft bgs) }\end{array}$ & $\begin{array}{l}\text { Sample } \\
\text { Matrix }\end{array}$ & Purpose & Analyses \\
\hline \multirow{4}{*}{ C19 } & $322 \mathrm{C} 095$ & $9-10$ & Soil & $\mathrm{SC}$ & Set 8, SVOCs \\
\hline & $322 \mathrm{C} 100$ & $49-50$ & Soil & $\mathrm{SC}$ & Set 8, SVOCs \\
\hline & $322 \mathrm{C} 101$ & $59-60$ & Soil & SC & Set 8, SVOCs \\
\hline & $322 \mathrm{C} 102$ & $69-70$ & Soil & SC & Set 8, SVOCs \\
\hline IJ-1 sump & $322 \mathrm{C} 041$ & $60-61$ & Liquid & SC & $\begin{array}{c}\text { Sets } 1,4, \text { and } \\
\text { TPH-DRO, Iso-U }\end{array}$ \\
\hline NA & $322 C 301$ & NA & Water & Trip Blank & Total VOCs \\
\hline NA & $322 \mathrm{C} 302$ & NA & Water & Trip Blank & Total VOCs \\
\hline NA & $322 \mathrm{C} 303$ & NA & Water & Trip Blank & Total VOCs \\
\hline NA & $322 \mathrm{C} 304$ & NA & Water & $\begin{array}{c}\text { Equipment } \\
\text { Rinsate Blank }\end{array}$ & Sets $1,2,3,5$, and 6 \\
\hline NA & $322 C 305$ & NA & Water & Source Blank & Sets $1,2,3,5$, and 6 \\
\hline $\mathrm{NA}$ & $322 C 306$ & NA & Water & Trip Blank & Total VOCs \\
\hline $\mathrm{NA}$ & $322 \mathrm{C} 307$ & $\mathrm{NA}$ & Water & Trip Blank & Total VOCs \\
\hline NA & $322 C 308$ & NA & Water & $\begin{array}{c}\text { Equipment } \\
\text { Rinsate Blank }\end{array}$ & Sets $1,2,3,5$, and 6 \\
\hline $\mathrm{NA}$ & $322 C 309$ & NA & Water & Field Blank & Sets $1,2,3,5$, and 6 \\
\hline $\mathrm{NA}$ & $322 C 310$ & NA & Water & Source Blank & Sets $1,2,3,5$, and 6 \\
\hline NA & $322 \mathrm{C} 311$ & NA & Water & Trip Blank & Total VOCs \\
\hline $\mathrm{NA}$ & $322 \mathrm{C} 312$ & NA & Water & Trip Blank & Total VOCs \\
\hline $\mathrm{NA}$ & $322 \mathrm{C} 313$ & NA & Water & Trip Blank & Total VOCs \\
\hline $\mathrm{NA}$ & $322 \mathrm{C} 314$ & NA & Water & Trip Blank & Total VOCs \\
\hline NA & $322 \mathrm{C} 315$ & NA & Water & Trip Blank & Total VOCs \\
\hline NA & $322 C 318$ & NA & Water & Trip Blank & Total VOCs \\
\hline NA & $322 C 319$ & NA & Water & Trip Blank & Total VOCs \\
\hline $\mathrm{NA}$ & $322 \mathrm{C} 320$ & NA & Water & Trip Blank & Total VOCs \\
\hline NA & $322 \mathrm{C} 321$ & NA & Water & $\begin{array}{c}\text { Equipment } \\
\text { Rinsate Blank }\end{array}$ & Sets 1 through 6 \\
\hline NA & $322 \mathrm{C} 322$ & NA & Water & $\begin{array}{c}\text { Equipment } \\
\text { Rinsate Blank }\end{array}$ & Sets 1 through 6 \\
\hline $\mathrm{NA}$ & $322 \mathrm{C} 323$ & NA & Water & Trip Blank & Total VOCs \\
\hline $\mathrm{NA}$ & $322 \mathrm{C} 324$ & $\mathrm{NA}$ & Water & Trip Blank & Total VOCs \\
\hline $\mathrm{NA}$ & $322 \mathrm{C} 325$ & $\mathrm{NA}$ & Water & Trip Blank & Total VOCs \\
\hline $\mathrm{NA}$ & $322 \mathrm{C} 326$ & NA & Water & Source Blank & Sets 1 through $6^{b}$ \\
\hline NA & $322 \mathrm{C} 327$ & NA & Water & Trip Blank & Total VOCs \\
\hline $\mathrm{NA}$ & $322 \mathrm{C} 328$ & NA & Water & Trip Blank & Total VOCs \\
\hline NA & $322 C 329$ & NA & Water & $\begin{array}{c}\text { Equipment } \\
\text { Rinsate Blank }\end{array}$ & Sets 1 through 6 \\
\hline $\mathrm{NA}$ & $322 C 330$ & $\mathrm{NA}$ & Water & Trip Blank & Total VOCs \\
\hline
\end{tabular}


Table A.5-1

Samples Collected at CAS 03-20-05, Injection Well

(Page 5 of 5 )

\begin{tabular}{|c|c|c|c|c|c||}
\hline $\begin{array}{c}\text { Sample } \\
\text { Location }\end{array}$ & $\begin{array}{c}\text { Sample } \\
\text { Number }\end{array}$ & $\begin{array}{c}\text { Depth } \\
\text { (ft bgs) }\end{array}$ & $\begin{array}{c}\text { Sample } \\
\text { Matrix }\end{array}$ & Purpose & Analyses \\
\hline \hline NA & $322 \mathrm{C} 331$ & NA & Water & Trip Blank & Total VOCs \\
\hline NA & $322 \mathrm{C} 332$ & NA & Water & Trip Blank & Total VOCs \\
\hline NA & $322 \mathrm{C} 333$ & NA & Water & Trip Blank & Total VOCs \\
\hline NA & $322 \mathrm{C} 334$ & NA & Water & Field Blank & Sets 1 through 6 \\
\hline NA & $322 \mathrm{C} 335$ & NA & Water & Field Blank & Iso-U \\
\hline NA & $322 \mathrm{C} 336$ & NA & Water & Field Blank & Set 8 \\
\hline NA & 322C337 & NA & Water & Field Blank & SVOCs \\
\hline
\end{tabular}

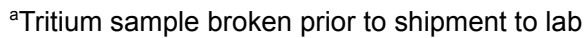

${ }^{\text {bPCB not analyzed }}$

Set 1 = Total VOCs, Total SVOCs, Total RCRA Metals, Total Beryllium, PCBs

Set 2 = Gamma Spectroscopy

Set 3 = Isotopic Uranium, Isotopic Plutonium, Strontium-90

Set $4=$ Gross Alpha, Gross Beta

Set $5=$ Tritium

Set $6=$ TPH-GRO, TPH-DRO

Set $7=$ TCLP VOCs, TCLP SVOCs, TCLP RCRA Metals

Set 8 = Total RCRA Metals, PCBs, Gamma Spectroscopy, Iso-uranium, Iso-plutonium, strontium-90 $\mathrm{ft}$ bgs = Feet below ground surface

$\mathrm{NA}=$ Not applicable

$\mathrm{SC}=$ Site characterization

$\mathrm{WC}=$ Waste characterization

$\mathrm{HT}=$ Holding tank

$\mathrm{IJ}=$ Injection well

injection well sumps, soils, and sample analysis. Also, a full, gridded, rad survey was conducted of the BOP Shop floor, holding/cleaning tank interiors and lids, and injection well casing interior and cover. One additional sample location was identified upon discovery of a sink within the BOP Shop with a flexible tube drain that ran through the shop wall and onto the ground just outside.

\section{A.5.2.1 Radiological Survey Results}

A radiological walk-over survey was performed at CAS 03-20-05 in April 2004. The survey was performed to determine if radiological contamination is present in surficial soil at CAS 03-20-05 at concentrations statistically greater than surficial soil from undisturbed background locations. The results were plotted on a color-coded contour map (Figure A.5-3).

Measurements of the gamma radiation emission rate for surface soils was performed with a TSA Systems Model PRM-470B handheld plastic scintillator over an area of approximately $8,837 \mathrm{ft}^{2} . \mathrm{A}$ total of 4,605 data points were recorded at this site with a mean gamma radiation emission rate of 166 counts per second versus the mean undisturbed background radiation emission rate of 176 counts 


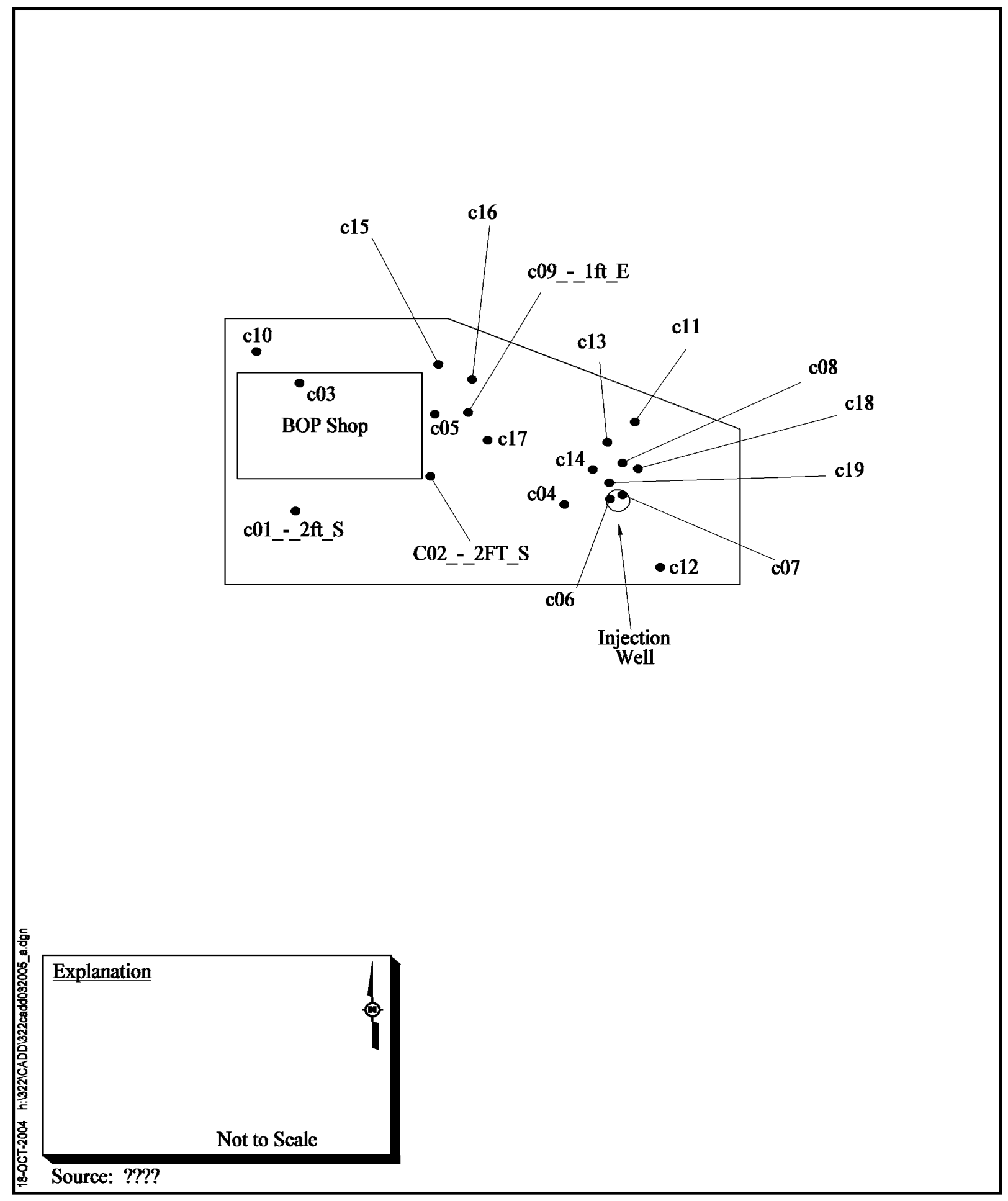

Figure A.5-1

Soil Sample Location Map for CAS 03-20-05, Injection Wells 


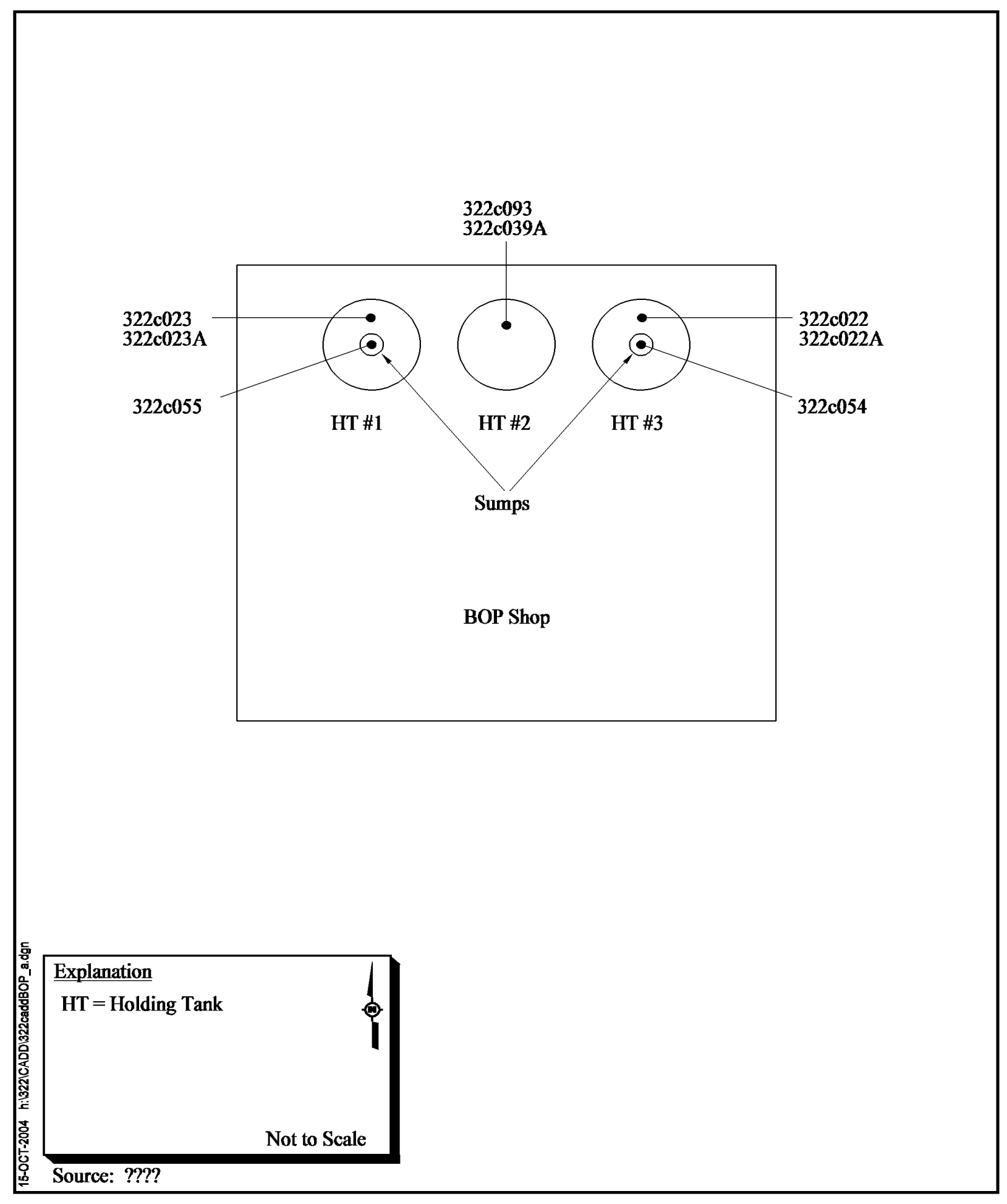

Figure A.5-2

Sample Locations for Tanks and Sumps at CAS 03-20-05, Injection Wells 


\section{CAU 322 \\ Mud Plant \\ CAS 03-20-05 \\ Injection Well and Blowout Prevention Shop}

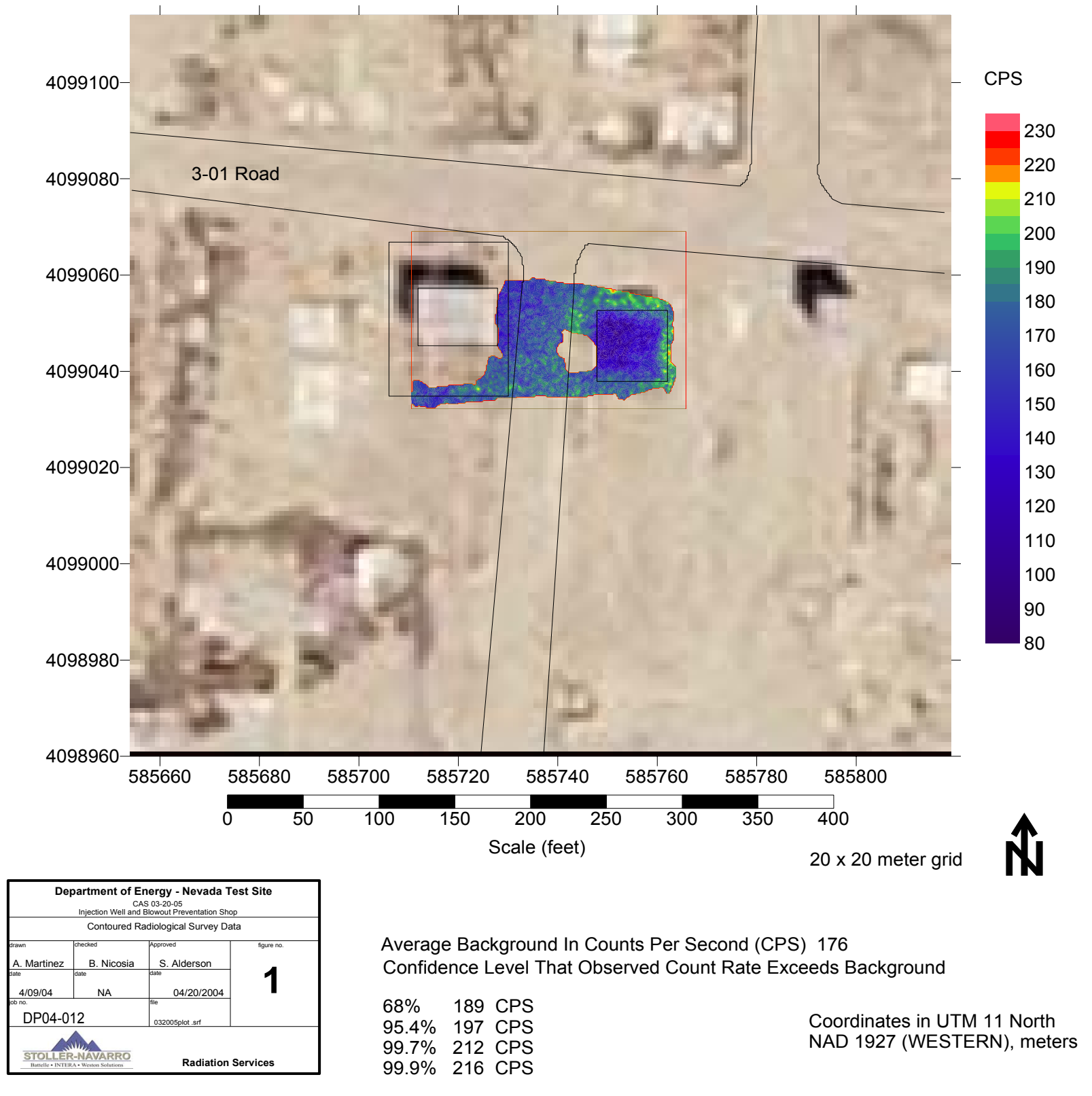

Figure A.5-3

Radiological Survey Map for CAS 03-20-05, Injection Wells 
per second. The maximum gamma radiation emission rate was 234 counts per second. This rate is approximately 1.3 times the mean undisturbed background gamma emission rate (Alderson, 2004).

A gridded survey was performed over the floor of the BOP Shop. The entire floor was divided into 2 by $2 \mathrm{ft}$ square grids, and a swipe sample was taken within each grid. Analysis of the swipe samples indicated that there were no measurements above the unrestricted release criteria.

A radiological survey was conducted on the tank interior walls and lids of the three holding tanks within the BOP Shop. Random swipe samples were collected at various locations on the inside walls of the holding tanks and on the bottom of the tank lids (the tops of the lids were sampled in the gridded survey of the BOP Shop floor). Analysis of the swipe samples indicated that no radiation existed above the unrestricted release criteria.

Swipe samples were collected from the interior walls of the injection well casing and from the top and bottom of the injection well cover. Analysis of these samples indicated that no radiological contamination existed above the unrestricted release criteria.

A datalogger radiological probe was lowered into the injection well sump and readings were collected at 10 -ft intervals from the top of the sump to the level of its liquid contents, beginning approximately $60 \mathrm{ft}$ bgs. The readings were all below background levels established prior to the injection well sump measurements.

\section{A.5.2.2 Inspection and Sampling}

The holding/cleaning tanks within the BOP Shop and line running from the BOP Shop to the injection well were inspected for integrity and leakage. The injection well casing was inspected for standing liquids; none were present. The injection well sump depth was determined to be approximately $62 \mathrm{ft}$ bgs with liquid beginning at $60 \mathrm{ft}$ bgs. A video mole was run the length of the 10 in. diameter injection well sump and it was determined that there was a pipe joint at $25 \mathrm{ft}$ bgs and that the pipe was slotted beginning at $28 \mathrm{ft}$ bgs. The slotting of the lower pipe became more crusted as the depth increased, and by approximately $50 \mathrm{ft}$ bgs, the slotting became difficult to visualize. It was unidentifiable due to crusting over the entire inner pipe surface at a depth of approximately $55 \mathrm{ft}$ bgs. Samples of all liquids in the holding/cleaning tanks and associated sumps and liquids contained 
within the injection well sump were collected. Soil samples were collected from specified locations selected to provide information regarding environmental contamination arising from leakage associated with the holding/cleaning tanks, drain line, and injection well and associated sump.

Swipe samples for radiation contamination were obtained from the locations identified in Section A.5.2 and the CAU 322 CAIP.

\section{A.5.2.3 Field-Screening Results}

Field screening of samples for VOCs using a FID detector identified no contamination above the PAL of $20 \mathrm{ppm}$. Field screening samples for TPH-DRO identified levels of the contaminant above the PAL of 75 ppm at several locations, predominantly within the soils in the injection well vault.

Radiological field screening of all samples was performed, and none of the results indicated readings above that of background.

\section{A.5.2.4 Sample Analysis}

Investigation samples were analyzed for the CAIP-specified COPCs which included total VOCs, total SVOCs, total and TCLP (where applicable) RCRA metals, total beryllium, TPH (DRO and GRO), PCBs, gamma-emitting radionuclides, isotopic uranium, isotopic plutonium, strontium-90, tritium, and alpha/beta emitting radionuclides. The analytical parameters and laboratory methods used to analyze the investigation samples are listed in Table A.2-2. Table A.5-1 lists the sample-specific analytical suite for CAS 03-20-05.

\section{A.5.2.5 Analytes Detected Above Minimum Reporting Limits}

Analytical results from samples with concentrations exceeding MRLs or MDCs are summarized in the following sections. Although the liquid and oil samples obtained from the holding/cleaning tanks and associated sumps will be used primarily for waste characterization purposes, the sample results are presented in this section for completeness. Analytical results from the soil, liquid, and oil samples with concentrations exceeding MRLs or MDCs are summarized in the following sections. These results are compared to PALs and are a subset of the results that exceed MRLs or MDCs. A portion 
of the analytical results for this CAS were rejected during validation; however, these rejected data did not adversely impact closure decisions as discussed in Appendix B, Section B.1.4.

\section{A.5.2.5.1 Total VOCs}

Total VOC analytical results for soil samples collected at CAS 03-20-05, which were detected above MRLs, are presented in Table A.5-2. No VOCs were detected in soil samples above PALs.

Table A.5-2

Soil Sample Results for Total VOCs Detected Above Minimum Reporting Limits at CAS 03-20-05, Injection Well

\begin{tabular}{|c|c|c|c|c|c|c||}
\hline \multirow{2}{*}{$\begin{array}{c}\text { Sample } \\
\text { Location }\end{array}$} & \multirow{2}{*}{$\begin{array}{c}\text { Sample } \\
\text { Number }\end{array}$} & \multirow{2}{*}{$\begin{array}{c}\text { Depth } \\
\text { (ft bgs) }\end{array}$} & \multicolumn{4}{|c|}{ Contaminants of Potential Concern $(\mu \mathrm{g} / \mathrm{kg})$} \\
\cline { 4 - 7 } & & & 2-Butanone & 2-Hexanone & 4-Methyl-2-Pentanone & Acetone \\
\hline \multicolumn{2}{|c|}{ Preliminary Action Levels ${ }^{\mathrm{a}}$} & $\mathbf{2 7 , 0 0 0}$ & $\mathbf{N I}$ & $\mathbf{2 , 8 0 0}$ & $\mathbf{6 , 0 0 0 , 0 0 0}$ \\
\hline \hline \multirow{2}{*}{$\mathrm{C} 07$} & $322 \mathrm{C} 019$ & $0-2$ & $97(\mathrm{~J})$ & $87(\mathrm{~J})$ & $74(\mathrm{~J})$ & $350(\mathrm{~J})$ \\
\cline { 2 - 7 } & $322 \mathrm{C} 021$ & $5-6$ & -- & -- & -- & 25 \\
\hline $\mathrm{C} 08$ & $322 \mathrm{C} 030$ & $60-61$ & -- & -- & -- & 24 \\
\hline
\end{tabular}

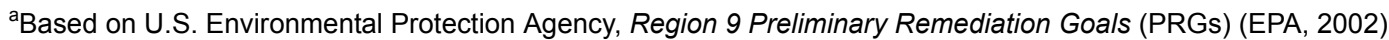

$\mathrm{ft}$ bgs $=$ Feet below ground surface

$\mu \mathrm{g} / \mathrm{kg}=$ Micrograms per kilogram

$\mathrm{J}=$ Estimated value. Qualifier added to laboratory data; record accepted. Surrogate recovery exceeded the upper limits.

-- = Not detected above minimum reporting limits.

\section{A.5.2.5.2 Total SVOCs}

Total SVOC analytical results for soil samples collected at CAS 03-20-05, which were detected above MRLs, are presented in Table A.5-3. No SVOCs were detected in soil samples above PALs.

\section{A.5.2.5.3 Total RCRA Metals and Beryllium}

Analytical results for total RCRA metals and beryllium for soil samples collected at CAS 03-20-05, which were detected above MRLs, are presented in Table A.5-4. Samples collected from the soil within the injection well exhibited results above the PAL for lead. Samples 322C016 and 322C019 collected at locations C06 ( 0 to $0.5 \mathrm{ft}$ bgs interval) and C07 (0 to $2 \mathrm{ft}$ bgs interval) provided results for lead of 2,500 and 1,500 mg/kg respectively. Samples collected below these intervals were below the PAL for lead. 
Table A.5-3

\section{Soil Sample Results for Total SVOCs Detected Above Minimum Reporting Limits at CAS 03-20-05, Injection Well}

\begin{tabular}{|c|c|c|c||}
\hline \multirow{2}{*}{$\begin{array}{c}\text { Sample } \\
\text { Location }\end{array}$} & \multirow{2}{*}{$\begin{array}{c}\text { Sample } \\
\text { Number }\end{array}$} & $\begin{array}{c}\text { Depth } \\
\text { (ft bgs) }\end{array}$ & Contaminants of Potential Concern $(\mu \mathrm{g} / \mathrm{kg})$ \\
\cline { 3 - 4 } & & & Bis(2-Ethylhexyl)Phthalate \\
\hline \multicolumn{2}{|c|}{ Preliminary Action Levels } & $\mathbf{1 2 0 , 0 0 0}$ \\
\hline \hline C06 & $322 \mathrm{C} 016$ & $0-1$ & $8,900(\mathrm{~J})$ \\
\hline $\mathrm{C} 07$ & $322 \mathrm{C} 019$ & $0-2$ & $6,800(\mathrm{~J})$ \\
\hline
\end{tabular}

aBased on U.S. Environmental Protection Agency, Region 9 Preliminary Remediation Goals (PRGs) (EPA, 2002)

$\mathrm{ft}$ bgs $=$ Feet below ground surface $\mu \mathrm{g} / \mathrm{kg}=$ Micrograms per kilogram

$\mathrm{J}=$ Estimated value. Qualifier added to laboratory data; record accepted. Matrix effects may exist. Internal area response show extremely low count.

\section{A.5.2.5.4 PCBs}

Analytical results for PCBs in samples collected at CAS 03-20-05, which were detected above MRLs, are presented in Table A.5-5. Sample 322C024 collected at sample location C08 indicated Aroclor- 1254 at a concentration of $1.1 \mathrm{mg} / \mathrm{kg}$ at a depth of 0 to $2 \mathrm{ft}$ bgs. Samples collected around and below this location and interval were below the PAL. Samples 322C016 and 322C019 collected from the injection well soil at locations $\mathrm{C} 06$ and $\mathrm{C} 07$ at depths of 0 to 1 and 0 to $2 \mathrm{ft} \mathrm{bgs,}$ respectively, indicated Arolclor-1254 results of 3.3 and $2.4 \mathrm{mg} / \mathrm{kg}$. Samples collected below these intervals were below the PAL for Aroclor-1254.

\section{A.5.2.5.5 TPH}

Total TPH-DRO analytical results for soil samples collected at CAS 03-20-05, which were detected above MRLs, are presented in Table A.5-6. Total petroleum hydrocarbons analytical results for samples collected at CAS 03-20-05 indicated the presence of TPH-DRO above PALs at several locations.

At sample location C18, TPH-DRO was detected at a concentration of $150 \mathrm{mg} / \mathrm{kg}$. This detection is presumably due to the presence of asphalt at the site surface. Analytical results for surface samples collected at several other locations (i.e., C02, C04, C05, C08, C09, and C11) indicated TPH-DRO at concentrations over the MRL but less than the PAL. Samples collected below each of these locations 
Table A.5-4

Soil Sample Results for Metals Detected Above Minimum Reporting Limits at CAS 03-20-05, Injection Well (Page 1 of 5 )

\begin{tabular}{|c|c|c|c|c|c|c|c|c|c|c|c|}
\hline \multirow{2}{*}{$\begin{array}{l}\text { Sample } \\
\text { Location }\end{array}$} & \multirow{2}{*}{$\begin{array}{l}\text { Sample } \\
\text { Number }\end{array}$} & \multirow{2}{*}{$\begin{array}{c}\text { Depth } \\
\text { (ft bgs) }\end{array}$} & \multicolumn{9}{|c|}{ Contaminants of Potential Concern (mg/kg) } \\
\hline & & & Arsenic & Barium & Beryllium & Cadmium & Chromium & Lead & Mercury & Selenium & Silver \\
\hline \multicolumn{3}{|c|}{ Preliminary Action Levels } & $23^{a}$ & $67,000^{b}$ & $1,900^{b}$ & $450^{b}$ & $450^{b}$ & $750^{b}$ & $310^{b}$ & $5,100^{b}$ & $5,100^{b}$ \\
\hline \multirow{3}{*}{$\mathrm{C} 01$} & $322 \mathrm{C} 001$ & $0-0.5$ & 6.4 & 300 & 0.66 & -- & 6.4 & 12 & -- & $0.61(\mathrm{~J}-)$ & -- \\
\hline & $322 \mathrm{C} 002$ & $2-3$ & 4.3 & 150 & 0.79 & -- & 5.9 & 9.6 & -- & -- & -- \\
\hline & $322 \mathrm{C003}$ & $4-5$ & 4 & 140 & 0.57 & -- & 4.3 & 12 & -- & - & -- \\
\hline \multirow{3}{*}{$\mathrm{C02}$} & $322 \mathrm{C} 004$ & $0-0.5$ & 4.8 & 170 & 0.76 & 0.89 & 8.8 & 41 & -- & -- & -- \\
\hline & $322 \mathrm{C} 005$ & $2-3$ & 4.3 & 130 & 0.85 & -- & 6.5 & 9.9 & -- & -- & -- \\
\hline & $322 \mathrm{C} 006$ & $5-6$ & 5.4 & 120 & 0.97 & -- & 7 & 12 & -- & -- & -- \\
\hline \multirow{3}{*}{$\mathrm{CO3}$} & $322 \mathrm{C} 007$ & $0-0.5$ & 4.6 & 140 & 0.79 & -- & 6.1 & 15 & -- & -- & -- \\
\hline & $322 \mathrm{C} 008$ & $2-3$ & 4.9 & 150 & 0.96 & -- & 6.9 & 12 & -- & -- & -- \\
\hline & $322 \mathrm{C} 009$ & $5-6$ & 3.1 & 100 & -- & -- & 4.2 & 8.2 & -- & -- & -- \\
\hline \multirow{4}{*}{$\mathrm{C} 04$} & $322 \mathrm{C} 010$ & $0-0.5$ & 6.2 & 190 & 0.67 & -- & 7.6 & 21 & -- & -- & -- \\
\hline & $322 \mathrm{C} 011$ & $4-5$ & 7.1 & 140 & 1.2 & -- & 8.3 & 13 & -- & -- & -- \\
\hline & $322 \mathrm{C} 012$ & $7-8$ & 5.1 & 120 & 0.76 & -- & 5.5 & 12 & -- & -- & -- \\
\hline & $322 \mathrm{C} 013$ & $7-8$ & 5.3 & 120 & 0.78 & -- & 5.9 & 10 & -- & -- & -- \\
\hline \multirow{3}{*}{ C05 } & $322 \mathrm{C} 013 \mathrm{~A}$ & $0-0.5$ & 3.7 & 130 & 0.57 & 7.4 & 7.7 & 42 & -- & -- & -- \\
\hline & $322 \mathrm{C} 014$ & $2-3$ & 4.7 & 160 & 0.87 & 0.6 & 7.5 & 15 & -- & -- & -- \\
\hline & $322 \mathrm{C} 015$ & $5-6$ & 6.2 & 170 & 1 & -- & 7.7 & 16 & -- & -- & -- \\
\hline \multirow{3}{*}{$\mathrm{C} 06$} & $322 \mathrm{C} 016$ & $0-1$ & 8.3 & 460 & -- & 320 & 170 & 2,500 & 1.4 & -- & 1.4 \\
\hline & $322 \mathrm{C} 017$ & $3-4$ & 5.1 & 190 & 0.7 & 22 & 13 & 170 & 0.52 & 0.74 & -- \\
\hline & $322 \mathrm{C} 018$ & $5-6$ & 9 & 240 & 0.74 & 45 & 22 & 420 & 0.77 & 0.94 & -- \\
\hline
\end{tabular}


Table A.5-4

Soil Sample Results for Metals Detected Above Minimum Reporting Limits at CAS 03-20-05, Injection Well (Page 2 of 5 )

\begin{tabular}{|c|c|c|c|c|c|c|c|c|c|c|c|}
\hline \multirow{2}{*}{$\begin{array}{l}\text { Sample } \\
\text { Location }\end{array}$} & \multirow{2}{*}{$\begin{array}{l}\text { Sample } \\
\text { Number }\end{array}$} & \multirow{2}{*}{$\begin{array}{c}\text { Depth } \\
\text { (ft bgs) }\end{array}$} & \multicolumn{9}{|c|}{ Contaminants of Potential Concern (mg/kg) } \\
\hline & & & Arsenic & Barium & Beryllium & Cadmium & Chromium & Lead & Mercury & Selenium & Silver \\
\hline \multicolumn{3}{|c|}{ Preliminary Action Levels } & $23^{a}$ & $67,000^{b}$ & $1,900^{b}$ & $450^{b}$ & $450^{b}$ & $750^{b}$ & $310^{b}$ & $5,100^{b}$ & $5,100^{b}$ \\
\hline \multirow{6}{*}{$\mathrm{C} 07$} & $322 \mathrm{C} 019$ & $0-2$ & 10 & 320 & -- & 130 & 96 & 1,500 & 0.97 & 0.79 & $\overline{2}$ \\
\hline & $322 \mathrm{C} 020$ & $3-4$ & 6.2 & 170 & 0.74 & 13 & 14 & 110 & 0.17 & -- & -- \\
\hline & $322 \mathrm{C} 021$ & $5-6$ & 5.5 & 210 & 0.68 & 17 & 15 & 150 & 0.2 & -- & -- \\
\hline & $322 \mathrm{C} 091$ & $14-15$ & 4.1 & 230 & -- & -- & 4.7 & 13 & -- & - & -- \\
\hline & $322 \mathrm{C} 092$ & $19-20$ & 6.6 & 260 & -- & - & 7.6 & 10 & - & - & -- \\
\hline & $322 \mathrm{C} 093$ & $24-25$ & 3.7 & 120 & - & - & 6.7 & 8.5 & - & - & - \\
\hline \multirow{13}{*}{$\mathrm{C} 08$} & $322 \mathrm{C} 024$ & $0-2$ & 4.6 & 220 & 0.69 & - & 10 & 38 & -- & - & - \\
\hline & $322 \mathrm{C} 025$ & $9-10$ & 4 & 110 & 0.65 & - & 5.2 & 8.4 & - & - & - \\
\hline & $322 \mathrm{C} 026$ & $20-21$ & 6.3 & 260 & 0.92 & - & 7.4 & 12 & -- & - & -- \\
\hline & $322 \mathrm{C} 027$ & $30-31$ & 5.6 & 130 & 0.93 & $\overline{--}$ & 6.5 & 11 & $\overline{--}$ & $\overline{--}$ & 1.6 \\
\hline & $322 \mathrm{C} 028$ & $40-41$ & 4.6 & 140 & 0.89 & -- & 6.1 & 9.8 & - & - & 1.5 \\
\hline & $322 \mathrm{C029}$ & $50-51$ & 4.1 & 150 & 0.71 & - & 8.9 & 16 & - & - & -- \\
\hline & $322 \mathrm{C0} 030$ & $60-61$ & 4.8 & 160 & 0.99 & -- & 6.5 & 12 & -- & - & -- \\
\hline & $322 \mathrm{C} 031$ & $70-71$ & 3.6 & 110 & 0.73 & -- & 5.2 & 8.7 & -- & -- & -- \\
\hline & $322 \mathrm{C} 032$ & $80-81$ & 2.8 & 110 & 0.69 & - & 2.9 & 7.3 & -- & - & -- \\
\hline & $322 \mathrm{C} 033$ & $91-92$ & 5.7 & 130 & 1 & - & 6.6 & 11 & - & - & -- \\
\hline & $322 \mathrm{C} 034$ & $100-101$ & 3.5 & 110 & 0.8 & -- & 4.4 & 11 & - & - & -- \\
\hline & $322 \mathrm{C} 035$ & $111-112$ & 4.1 & 140 & 0.93 & -- & 15 & 8.4 & -- & - & -- \\
\hline & $322 \mathrm{C} 036$ & $122-123$ & 5.3 & 130 & 0.84 & - & 7.6 & 10 & - & - & $1.1(\mathrm{~B})$ \\
\hline
\end{tabular}


Table A.5-4

Soil Sample Results for Metals Detected Above Minimum Reporting Limits at CAS 03-20-05, Injection Well (Page 3 of 5 )

\begin{tabular}{|c|c|c|c|c|c|c|c|c|c|c|c|}
\hline \multirow{2}{*}{$\begin{array}{l}\text { Sample } \\
\text { Location }\end{array}$} & \multirow{2}{*}{$\begin{array}{l}\text { Sample } \\
\text { Number }\end{array}$} & \multirow{2}{*}{$\begin{array}{c}\text { Depth } \\
\text { (ft bgs) }\end{array}$} & \multicolumn{9}{|c|}{ Contaminants of Potential Concern (mg/kg) } \\
\hline & & & Arsenic & Barium & Beryllium & Cadmium & Chromium & Lead & Mercury & Selenium & Silver \\
\hline \multicolumn{3}{|c|}{ Preliminary Action Levels } & $23^{a}$ & $67,000^{b}$ & $1,900^{b}$ & $450^{b}$ & $450^{b}$ & $750^{b}$ & $310^{b}$ & $5,100^{b}$ & $5,100^{b}$ \\
\hline \multirow{14}{*}{ C09 } & $322 \mathrm{C} 037$ & $0-0.5$ & 5.3 & 140 & 0.71 & -- & $6.2(\mathrm{~J}+)$ & 14 & -- & -- & -- \\
\hline & $322 \mathrm{C} 038$ & $0-0.5$ & 4.3 & 140 & 0.75 & -- & $6.7(\mathrm{~J}+)$ & 27 & -- & $0.79(\mathrm{~J}-)$ & -- \\
\hline & $322 \mathrm{C} 042$ & $10-11$ & 4.5 & 160 & 0.92 & -- & $5.6(\mathrm{~J}+)$ & 12 & -- & -- & 1.4 \\
\hline & $322 \mathrm{C} 043$ & $20-21$ & 4.3 & 140 & 0.78 & -- & $6.6(\mathrm{~J}+)$ & 8.4 & -- & -- & -- \\
\hline & $322 \mathrm{C} 044$ & $30-31$ & 3.9 & 130 & 0.7 & -- & $5(\mathrm{~J}+)$ & 7.6 & -- & -- & -- \\
\hline & $322 \mathrm{C} 045$ & $40-41$ & 4.3 & 140 & 0.81 & -- & $5.8(\mathrm{~J}+)$ & 9.3 & -- & -- & -- \\
\hline & $322 \mathrm{C} 046$ & $51-52$ & 4.6 & 180 & 0.76 & -- & 11 & 8.5 & -- & -- & 1.1 \\
\hline & $322 \mathrm{C} 047$ & $60-61$ & 3.3 & 150 & 0.66 & - & $4.8(\mathrm{~J}+)$ & 8.5 & - & 0.67 & -- \\
\hline & $322 C 048$ & $70-71$ & 4.5 & 120 & 0.78 & $\overline{--}$ & 42 & 9.7 & $\overline{--}$ & 0.56 & $\overline{--}$ \\
\hline & $322 C 049$ & $81-82$ & 3.2 & 150 & 0.9 & -- & $4.5(\mathrm{~J}+)$ & 22 & -- & -- & -- \\
\hline & $322 C 050$ & $92-93$ & 5.1 & 120 & 0.81 & -- & 5.6 & 9 & -- & -- & -- \\
\hline & $322 \mathrm{C051}$ & $101-102$ & 3.9 & 110 & 0.9 & -- & 5.5 & 8.2 & -- & -- & -- \\
\hline & $322 \mathrm{C} 052$ & $111-112$ & 5 & 150 & 1.1 & -- & 5.7 & 10 & -- & -- & -- \\
\hline & $322 \mathrm{C} 053$ & $121-122$ & 4.4 & 120 & 0.73 & -- & 5.3 & 8.9 & -- & -- & -- \\
\hline
\end{tabular}


Table A.5-4

Soil Sample Results for Metals Detected Above Minimum Reporting Limits at CAS 03-20-05, Injection Well (Page 4 of 5)

\begin{tabular}{|c|c|c|c|c|c|c|c|c|c|c|c|}
\hline \multirow{2}{*}{$\begin{array}{l}\text { Sample } \\
\text { Location }\end{array}$} & \multirow{2}{*}{$\begin{array}{l}\text { Sample } \\
\text { Number }\end{array}$} & \multirow{2}{*}{$\begin{array}{c}\text { Depth } \\
\text { (ft bgs) }\end{array}$} & \multicolumn{9}{|c|}{ Contaminants of Potential Concern (mg/kg) } \\
\hline & & & Arsenic & Barium & Beryllium & Cadmium & Chromium & Lead & Mercury & Selenium & Silver \\
\hline \multicolumn{3}{|c|}{ Preliminary Action Levels } & $23^{a}$ & $67,000^{b}$ & $1,900^{b}$ & $450^{b}$ & $450^{b}$ & $750^{b}$ & $310^{b}$ & $5,100^{b}$ & $5,100^{b}$ \\
\hline \multirow{12}{*}{ C10 } & $322 \mathrm{C} 056$ & $1-2$ & 3.3 & 130 & 0.69 & -- & 5 & 7.8 & -- & -- & -- \\
\hline & $322 \mathrm{C} 057$ & $10-11$ & 2.7 & 100 & -- & -- & 4.5 & 6.2 & -- & -- & -- \\
\hline & $322 \mathrm{C} 058$ & $21-22$ & 4.4 & 130 & 0.61 & -- & 7.8 & 9.2 & -- & -- & -- \\
\hline & $322 C 059$ & $30-31$ & 4.2 & 150 & 0.75 & -- & 5 & 8.2 & -- & -- & -- \\
\hline & $322 \mathrm{C} 060$ & $41-42$ & 4.9 & 140 & 0.96 & - & 6.1 & 9.6 & -- & - & -- \\
\hline & $322 \mathrm{C} 061$ & $51-52$ & 6 & 160 & 0.92 & - & 8 & 11 & - & 0.91 & - \\
\hline & $322 \mathrm{C} 062$ & $60-61$ & 4.3 & 140 & 0.78 & - & 5.6 & 9.2 & - & - & -- \\
\hline & $322 \mathrm{C} 063$ & $71-72$ & 3.1 & 98 & 0.55 & - & 3.8 & 7.4 & - & - & - \\
\hline & $322 \mathrm{C} 064$ & $81-82$ & 3.4 & 110 & 0.75 & -- & 3.6 & 12 & -- & - & -- \\
\hline & $322 \mathrm{C065}$ & $81-82$ & 2.7 & 99 & 0.68 & - & 3.2 & 7.3 & - & - & -- \\
\hline & $322 \mathrm{C066}$ & $91-92$ & 3 & 120 & 0.62 & -- & 3.4 & 9.2 & - & -- & -- \\
\hline & $322 \mathrm{C} 067$ & $101-102$ & 3.3 & 100 & 0.91 & -- & 5.1 & 8.6 & -- & -- & -- \\
\hline \multirow{4}{*}{ C11 } & $322 \mathrm{C} 068$ & $0-1$ & 4.4 & 140 & 0.82 & -- & 6.3 & 13 & 0.57 & -- & -- \\
\hline & $322 C 069$ & $49-50$ & 4.3 & 250 & 0.65 & -- & 4.2 & 8.6 & -- & -- & -- \\
\hline & $322 \mathrm{C} 070$ & $59-60$ & 3.3 & 200 & 0.73 & -- & 3.1 & 6.2 & -- & -- & -- \\
\hline & $322 \mathrm{C} 071$ & $69-70$ & 4 & 110 & 0.73 & -- & 4.6 & 8.4 & -- & -- & -- \\
\hline
\end{tabular}


Table A.5-4

Soil Sample Results for Metals Detected Above Minimum Reporting Limits at CAS 03-20-05, Injection Well (Page 5 of 5 )

\begin{tabular}{|c|c|c|c|c|c|c|c|c|c|c|c|}
\hline \multirow{2}{*}{$\begin{array}{l}\text { Sample } \\
\text { Location }\end{array}$} & \multirow{2}{*}{$\begin{array}{l}\text { Sample } \\
\text { Number }\end{array}$} & \multirow{2}{*}{$\begin{array}{c}\text { Depth } \\
\text { (ft bgs) }\end{array}$} & \multicolumn{9}{|c|}{ Contaminants of Potential Concern $(\mathrm{mg} / \mathrm{kg})$} \\
\hline & & & Arsenic & Barium & Beryllium & Cadmium & Chromium & Lead & Mercury & Selenium & Silver \\
\hline \multicolumn{3}{|c|}{ Preliminary Action Levels } & $23^{a}$ & $67,000^{b}$ & $1,900^{b}$ & $450^{b}$ & $450^{b}$ & $750^{b}$ & $310^{b}$ & $5,100^{b}$ & $5,100^{b}$ \\
\hline \multirow{4}{*}{$\mathrm{C} 12$} & $322 \mathrm{C} 072$ & $0-1$ & 4.4 & 150 & 0.76 & -- & 5.8 & 10 & -- & -- & -- \\
\hline & $322 \mathrm{C} 073$ & $49-50$ & 4.1 & 180 & 0.89 & -- & 5.9 & 10 & -- & -- & -- \\
\hline & $322 \mathrm{C} 074$ & $59-60$ & 4 & 180 & 0.78 & -- & 4.9 & 11 & -- & -- & -- \\
\hline & $322 \mathrm{C} 075$ & $69-70$ & 5 & 110 & 0.94 & -- & 5.6 & 9.9 & -- & 0.69 & -- \\
\hline \multirow{4}{*}{ C19 } & $322 \mathrm{C} 095$ & $9-10$ & 4.4 & 130 & - & - & 5.5 & 9.9 & - & -- & -- \\
\hline & $322 \mathrm{C} 100$ & $49-50$ & 6.2 & 180 & -- & -- & 8.3 & 10 & - & - & -- \\
\hline & $322 \mathrm{C} 101$ & $59-60$ & 4.2 & 150 & -- & -- & 9.1 & 11 & -- & -- & -- \\
\hline & $322 \mathrm{C} 102$ & $69-70$ & 3.3 & 130 & -- & -- & 6.7 & 7.7 & - & -- & -- \\
\hline
\end{tabular}

${ }^{a}$ Based on the background concentrations for metals. Background is considered the mean plus two times the standard deviation for sediment samples collected by the Nevada Bureau of Mines and Geology throughout the Nevada Test and Training Range (NBMG, 1998; Moore, 1999).

${ }^{\mathrm{b}}$ Based on U.S. Environmental Protection Agency, Region 9 Preliminary Remediation Goals (PRGs) (EPA, 2002)

$\mathrm{ft}$ bgs $=$ Feet below ground surface

$\mathrm{mg} / \mathrm{kg}=$ Milligrams per kilogram

$B=$ Analyte found in both sample and associated blank

$\mathrm{J}+=$ This result is an estimated quantity, but the result may be biased high. Field Blank or Equipment Rinsate Blank or Source Blank contamination.

$\mathrm{J}-=$ The result is an estimated quantity, but the result may be biased low. Negative bias found in continuing calibration/method blank.

-- = Not detected above minimum reporting limits 


\section{Table A.5-5 \\ Soil Sample Results for PCBs Detected Above Minimum Reporting Limits at CAS 03-20-05, Injection Well}

\begin{tabular}{|c|c|c|c|c|}
\hline \multirow{2}{*}{$\begin{array}{l}\text { Sample } \\
\text { Location }\end{array}$} & \multirow{2}{*}{$\begin{array}{l}\text { Sample } \\
\text { Number }\end{array}$} & \multirow{2}{*}{$\begin{array}{c}\text { Depth } \\
\text { (ft bgs) }\end{array}$} & \multicolumn{2}{|c|}{ Contaminants of Potential Concern $(\mu \mathrm{g} / \mathrm{kg})$} \\
\hline & & & Aroclor 1254 & Aroclor 1260 \\
\hline \multicolumn{3}{|c|}{ Preliminary Action Levels $^{a}$} & 740 & 740 \\
\hline$\overline{\mathrm{C} 01}$ & 322C001 & $0-0.5$ & $45(\mathrm{~J})^{\mathrm{b}}$ & $\overline{---}$ \\
\hline $\mathrm{C02}$ & $322 \mathrm{C} 004$ & $0-0.5$ & $71(\mathrm{~J})^{\mathrm{b}}$ & 89 \\
\hline $\mathrm{C03}$ & $322 \mathrm{C007}$ & $0-0.5$ & $130(\mathrm{~J})^{\mathrm{b}}$ & -- \\
\hline $\mathrm{C} 05$ & $322 \mathrm{C} 013 \mathrm{~A}$ & $0-0.5$ & $110(\mathrm{~J})^{\mathrm{b}}$ & -- \\
\hline \multirow{3}{*}{$\mathrm{C} 06$} & $322 \mathrm{C} 016$ & $0-1$ & $3,300(J)^{c}$ & -- \\
\hline & $322 \mathrm{C} 017$ & $3-4$ & $280(\mathrm{~J})^{d}$ & $\overline{--}$ \\
\hline & $322 \mathrm{C} 018$ & $5-6$ & $580(J)^{d}$ & -- \\
\hline \multirow{6}{*}{$\mathrm{C} 07$} & $322 \mathrm{C} 019$ & $0-2$ & $2,400(J)^{c}$ & -- \\
\hline & $322 \mathrm{C} 020$ & $3-4$ & $250(\mathrm{~J})^{\mathrm{d}}$ & -- \\
\hline & $322 \mathrm{C} 021$ & $5-6$ & $180(\mathrm{~J})^{\mathrm{d}}$ & -- \\
\hline & $322 \mathrm{C091}$ & $14-15$ & -- & 69 \\
\hline & $322 \mathrm{C092}$ & $19-20$ & 110 & 160 \\
\hline & $322 \mathrm{C} 093$ & $24-25$ & $130(\mathrm{~J})^{\mathrm{e}}$ & $140(\mathrm{~J})^{\mathrm{e}}$ \\
\hline $\mathrm{C08}$ & $322 \mathrm{C} 024$ & $0-2$ & $1,100(J)^{c}$ & -- \\
\hline \multirow{2}{*}{ C09 } & $322 \mathrm{C} 037$ & $0-0.5$ & $43(\mathrm{~J})^{\mathrm{b}}$ & -- \\
\hline & $322 \mathrm{C} 038$ & $0-0.5$ & $37(\mathrm{~J})^{\mathrm{b}}$ & - \\
\hline C19 & $322 \mathrm{C} 101$ & $59-60$ & $\overline{--}$ & 46 \\
\hline
\end{tabular}

a Based on U.S. Environmental Protection Agency, Region 9 Preliminary Remediation Goals (PRGs) (EPA, 2002)

${ }^{\mathrm{b}}$ Qualifier added to laboratory data; record accepted. \%D between columns $>25$.

${ }^{\mathrm{C}} \mathrm{Qualifier}$ added to laboratory data; record accepted. \%D between columns $>25$. Surrogates diluted out.

${ }^{\mathrm{d}}$ Qualifier added to laboratory data; record accepted. \%D between columns $>25$. Surrogate recovery exceeded the lower limits.

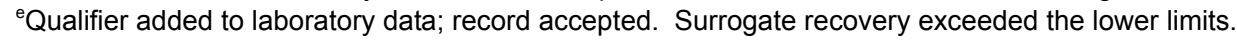

$\mathrm{ft}$ bgs $=$ Feet below ground surface

$\mu \mathrm{g} / \mathrm{kg}=$ Micrograms per kilogram

$\mathrm{J}=$ Estimated value.

-- = Not detected above minimum reporting limits.

and location C18 did not indicate TPH-DRO above the PAL. Asphalt is not considered an environmental contaminant when applied for its intended purpose; therefore, the detection of TPH-DRO above the PAL at location C18 is not considered a COC.

Higher levels of TPH contamination were identified in conjunction with the injection well including sample locations C06 and C07 inside the well vault and C08 and C19 outside the well vault. Concentrations of TPH-DRO at locations $\mathrm{C} 06$ and $\mathrm{C} 07$ were relatively high (maximum of $45,000 \mathrm{mg} / \mathrm{kg}$ ) and generally decreased with depth. At the maximum depth of location C06, 
Table A.5-6

Soil Sample Results for TPH-DRO Detected Above Minimum Reporting Limits at CAS 03-20-05, Injection Well

\begin{tabular}{|c|c|c|c|}
\hline \multirow{2}{*}{$\begin{array}{l}\text { Sample } \\
\text { Location }\end{array}$} & \multirow{2}{*}{$\begin{array}{l}\text { Sample } \\
\text { Number }\end{array}$} & \multirow{2}{*}{$\begin{array}{l}\text { Depth } \\
\text { (ft bgs) }\end{array}$} & \multirow{2}{*}{$\begin{array}{c}\text { Contaminants of Potential Concern }(\mathrm{mg} / \mathrm{kg}) \\
\text { Diesel Range Organics }\end{array}$} \\
\hline & & & \\
\hline \multicolumn{3}{|c|}{ Preliminary Action Levels ${ }^{a}$} & 100 \\
\hline $\mathrm{C02}$ & $322 \mathrm{C004}$ & $0-0.5$ & $26(\mathrm{H}, \mathrm{M})$ \\
\hline $\mathrm{CO4}$ & $322 \mathrm{C} 010$ & $0-0.5$ & $77(\mathrm{H}, \mathrm{M})$ \\
\hline $\mathrm{C} 05$ & $322 \mathrm{C} 013 \mathrm{~A}$ & $0-0.5$ & $40(\mathrm{H}, \mathrm{M})$ \\
\hline \multirow{3}{*}{$\mathrm{C} 06$} & $322 \mathrm{C} 016$ & $0-1$ & $45,000(\mathrm{~J})$ \\
\hline & $322 \mathrm{C} 017$ & $3-4$ & $6,600(\mathrm{~J})$ \\
\hline & $322 \mathrm{C} 018$ & $5-6$ & $6,400(\mathrm{~J})$ \\
\hline \multirow{6}{*}{$\mathrm{C} 07$} & 322C019 & $0-2$ & $35,000(\mathrm{~J})$ \\
\hline & $322 \mathrm{C} 020$ & $3-4$ & $5,900(\mathrm{~J})$ \\
\hline & $322 \mathrm{C} 021$ & $5-6$ & $3,300(\mathrm{~J})$ \\
\hline & 322C091 & $14-15$ & $2,000(\mathrm{H}, \mathrm{M})$ \\
\hline & 322C092 & $19-20$ & $1,100(H, M)$ \\
\hline & $322 \mathrm{C} 093$ & $24-25$ & $1,000(H, M)$ \\
\hline \multirow{3}{*}{$\mathrm{C} 08$} & $322 \mathrm{C} 024$ & $0-2$ & $91(\mathrm{H}, \mathrm{M})$ \\
\hline & $322 \mathrm{C} 029$ & $50-51$ & $57(\mathrm{H}, \mathrm{M})$ \\
\hline & $322 \mathrm{C0} 030$ & $60-61$ & $730(\mathrm{H}, \mathrm{M})$ \\
\hline \multirow{2}{*}{$\mathrm{C} 09$} & $322 \mathrm{C} 037$ & $0-0.5$ & $47(\mathrm{H}, \mathrm{M})$ \\
\hline & $322 \mathrm{C} 038$ & $0-0.5$ & $55(\mathrm{H}, \mathrm{M})$ \\
\hline C11 & 322C068 & $0-1$ & $45(\mathrm{H}, \mathrm{M})$ \\
\hline C18 & $322 \mathrm{C} 087$ & $0.5-1$ & $150(\mathrm{D}, \mathrm{M})$ \\
\hline \multirow{3}{*}{ C19 } & 322C095 & $9-10$ & $33(\mathrm{M})$ \\
\hline & 322C101 & $59-60$ & $1,800(\mathrm{H}, \mathrm{M})$ \\
\hline & $322 \mathrm{C} 102$ & $69-70$ & $32(\mathrm{H})$ \\
\hline
\end{tabular}

aBased on Nevada Administrative Code; Contamination of soil: Establishment of action levels (NAC, 2002)

$\mathrm{ft}$ bgs $=$ Feet below ground surface $\mathrm{mg} / \mathrm{kg}=$ Milligrams per kilogram

$\mathrm{D}=\mathrm{A}$ pattern resembling diesel was detected in the sample.

$\mathrm{H}=$ The fuel pattern was in the heavier end of the retention time window for the Analyte of interest

$M=$ A pattern resembling motor oil was detected.

$\mathrm{J}=$ Estimate value. Qualifier added to laboratory data; record accepted. Surrogates diluted out. 
5 to $6 \mathrm{ft}$ bgs, the concentration of TPH-DRO was $6,400 \mathrm{mg} / \mathrm{kg}$. At the maximum depth of location $\mathrm{C} 07,25$ to $25 \mathrm{ft}$ bgs, the concentration of TPH-DRO was $1,000 \mathrm{mg} / \mathrm{kg}$ (Figure A.5-4).

At locations C08 and C19 located approximately $16 \mathrm{ft}$ and $6 \mathrm{ft}$ from the injection well sump, respectively, TPH-DRO contamination was identified above the PAL only in samples collected at the 60 to $61 \mathrm{ft}$ bgs interval. Samples above and below this interval indicated no TPH-DRO contamination above PALs. The 60 to $61 \mathrm{ft}$ bgs interval approximately coincides with the observed depth of the injection well sump, approximately $62 \mathrm{ft}$ bgs.

The lateral extent of TPH-DRO contamination associated with the Injection Well was established by field screening and sample results at locations C11 to the north and C12 to the south. Contamination associated with the shallow subsurface around the vault does not appear to extend beyond the vault casing as demonstrated by the TPH-DRO results in C04 and C19. Contamination associated with the bottom of the injection well does not extend beyond approximately $20 \mathrm{ft}$ laterally from the injection well sump, as demonstrated by the fact that TPH-DRO was not detected above MRLs in samples collected at location C12. It is unclear if the contamination in the two zones are connected; however, for purposes of recommending a closure alternative it will be assumed the contamination extends the entire length of the injection well sump from the surface of the soils within the injection well vault to a depth of $62 \mathrm{ft}$ bgs (Figure A.5-4).

\section{A.5.2.5.6 Gamma-Emitting Radionuclides}

Analytical results for gamma-emitting radionuclides in soil samples collected at CAS 03-20-05, that exceeded MDCs are presented in Table A.5-7. Samples 322C020 and 322C021 at sample location $\mathrm{C} 07$ indicated americium-141 results of $19.7 \mathrm{pCi} / \mathrm{g}$ and $11.9 \mathrm{pCi} / \mathrm{g}$ at depths of 3 to $4 \mathrm{ft}$ bgs and 5 to $6 \mathrm{ft}$ bgs, respectively. Sample 322C021 at sample location C07 indicated a result for cesium-137 of $10.1 \mathrm{pCi} / \mathrm{g}$ at a depth of 5 to $6 \mathrm{ft}$ bgs. Additional samples were collected to determine the vertical extent of these contaminants. Samples collected below the original samples indicate the radiological contamination ends prior to $14 \mathrm{ft}$ bgs (a clean sample was obtained at 14 to $15 \mathrm{ft}$ bgs and the last dirty sample was obtained at 5 to $6 \mathrm{ft}$ bgs; no samples were collected in between). Sample analytical results for the 14 to $15 \mathrm{ft}$ bgs interval and those below this depth indicate a deficiency of the radiological contaminants relative to background levels. Lateral extent of contamination is believed 


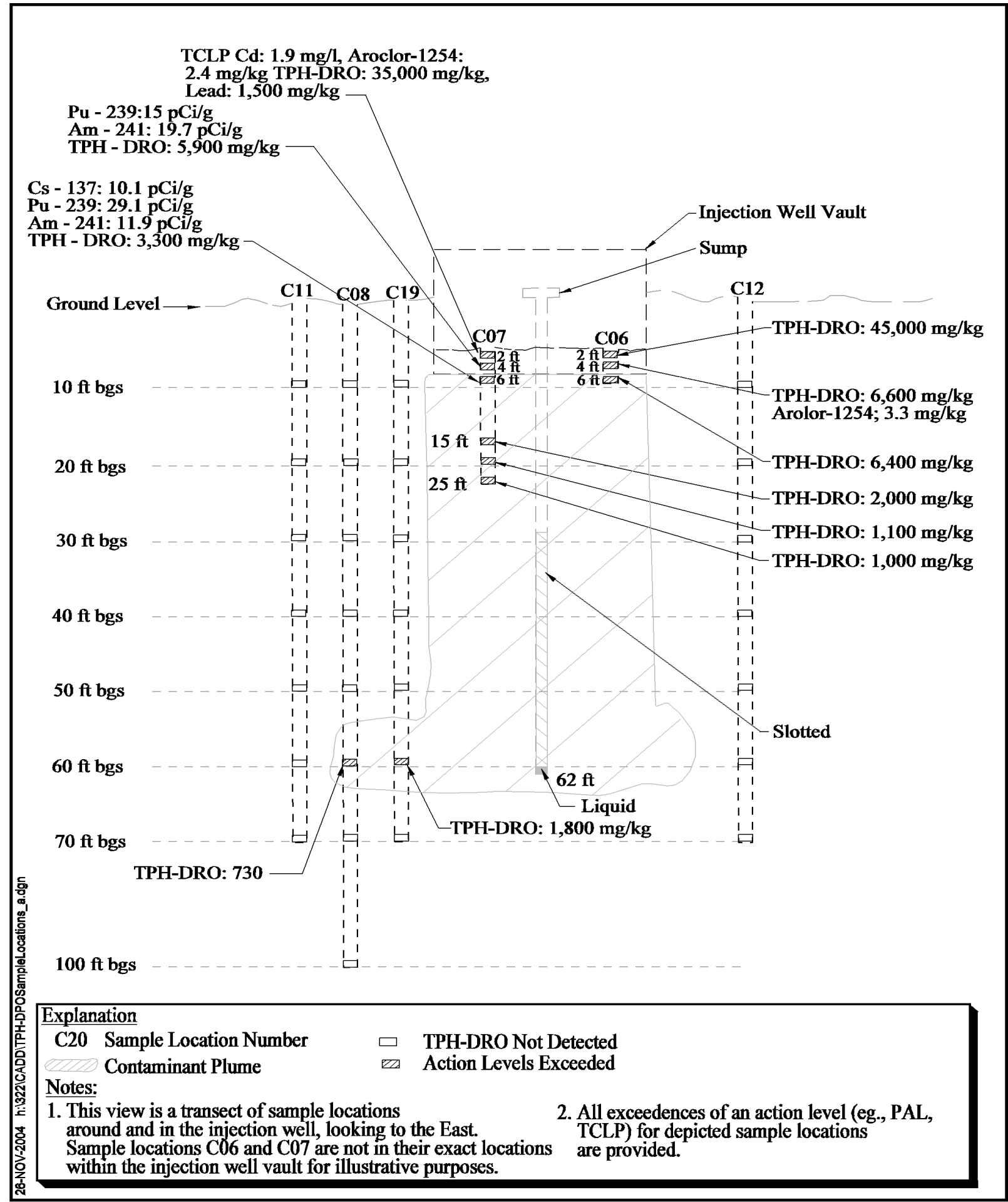

Figure A.5-4

Profile of Injection Well Sump and Vault with Analytical Results 
Table A.5-7

Soil Sample Results for Gamma-Emitting Radionuclides Detected Above Minimum Reporting Limits at CAS 03-20-05, Injection Well (Page 1 of 5)

\begin{tabular}{|c|c|c|c|c|c|c|c|c|c|c|c|c|c|c|c|c|c|c|}
\hline \multirow[b]{2}{*}{$\begin{array}{l}\text { Sample } \\
\text { Location }\end{array}$} & \multirow[b]{2}{*}{$\begin{array}{c}\text { Sample } \\
\text { Number }\end{array}$} & \multirow[b]{2}{*}{$\begin{array}{c}\text { Depth } \\
\text { (ft bgs) }\end{array}$} & \multicolumn{16}{|c|}{ Contaminants of Potential Concern (pCi/g) } \\
\hline & & & \multicolumn{2}{|c|}{ 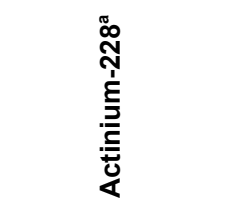 } & 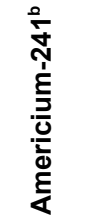 & \multicolumn{2}{|c|}{ 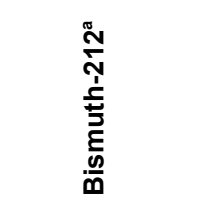 } & \multicolumn{2}{|c|}{ 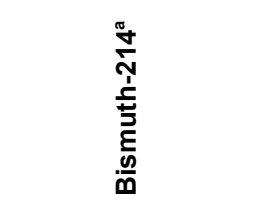 } & \multirow{3}{*}{ 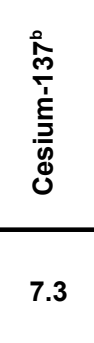 } & \multirow{3}{*}{ 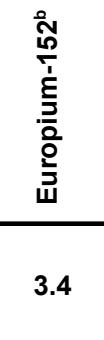 } & \multicolumn{2}{|c|}{ 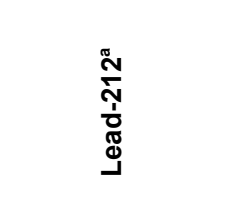 } & \multicolumn{2}{|c|}{ 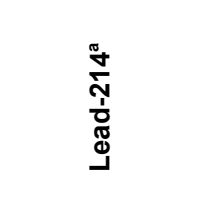 } & \multicolumn{2}{|c|}{ 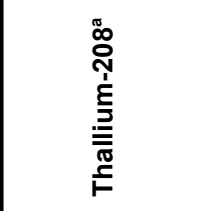 } & \multirow{3}{*}{ 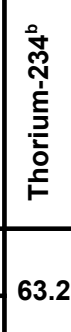 } \\
\hline Prelimin & ary Action & Levels & 5 & 15 & \multirow{2}{*}{7.62} & 5 & 15 & 5 & 15 & & & 5 & 15 & 5 & 15 & 5 & 15 & \\
\hline \multicolumn{3}{|c|}{ Depth bgs $(\mathrm{cm})$} & $<15$ & $>15$ & & $<15$ & $>15$ & $<15$ & $>15$ & & & $<15$ & $>15$ & $<15$ & $>15$ & $<15$ & $>15$ & \\
\hline \multirow{3}{*}{$\mathrm{C} 01$} & $\overline{322 \mathrm{C} 001}$ & $0-0.5$ & $\overline{1.72(\mathrm{G})}$ & $\overline{\mathrm{NA}}$ & $\overline{---}$ & $\overline{---}$ & $\overline{\mathrm{NA}}$ & $1.13(\mathrm{G})$ & $\overline{\mathrm{NA}}$ & $\overline{---}$ & $\overline{---}$ & $1.63(\mathrm{~J})$ & $\overline{\mathrm{NA}}$ & $\overline{c 1.27(\mathrm{~J})}$ & $\overline{\mathrm{NA}}$ & $0.51(\mathrm{G})$ & $\overline{\mathrm{NA}}$ & $3.2(\mathrm{~J})$ \\
\hline & $322 \mathrm{C} 002$ & $2-3$ & NA & $2.08(G)$ & -- & NA & -- & NA & 0.82 (G) & -- & -- & NA & $1.86(\mathrm{~J})$ & NA & $1.18(\mathrm{~J})$ & NA & $0.54(\mathrm{G})$ & -- \\
\hline & $322 \mathrm{C} 003$ & $4-5$ & $\mathrm{NA}$ & $1.68(\mathrm{G})$ & -- & NA & -- & NA & $0.97(\mathrm{G})$ & - & -- & NA & $1.91(\mathrm{~J})$ & $\mathrm{NA}$ & $1.13(\mathrm{~J})$ & $\mathrm{NA}$ & $0.47(G)$ & -- \\
\hline \multirow{3}{*}{$\mathrm{C} 02$} & $322 \mathrm{C} 004$ & $0-0.5$ & $1.65(\mathrm{G})$ & $\mathrm{NA}$ & $0.76(\mathrm{~J})$ & -- & $\mathrm{NA}$ & 1 (G) & $\mathrm{NA}$ & $1.05(\mathrm{G})$ & -- & $2.12(\mathrm{~J})$ & NA & $1.12(\mathrm{~J})$ & NA & $0.63(\mathrm{G})$ & $\mathrm{NA}$ & - \\
\hline & $322 \mathrm{C} 005$ & $2-3$ & $\mathrm{NA}$ & $1.72(\mathrm{G})$ & -- & NA & -- & $\mathrm{NA}$ & $1.32(\mathrm{G})$ & -- & -- & $\mathrm{NA}$ & $2.17(\mathrm{~J})$ & $\mathrm{NA}$ & $1.37(\mathrm{~J})$ & NA & $0.76(G)$ & -- \\
\hline & $322 \mathrm{C} 006$ & $5-6$ & $\mathrm{NA}$ & $1.96(\mathrm{G})$ & -- & NA & -- & $\mathrm{NA}$ & $1.55(\mathrm{G})$ & -- & -- & $\mathrm{NA}$ & $2.35(\mathrm{~J})$ & $\mathrm{NA}$ & $1.34(\mathrm{~J})$ & NA & $0.72(G)$ & - \\
\hline \multirow{3}{*}{$\mathrm{C} 03$} & $322 \mathrm{C} 007$ & $0-0.5$ & $1.93(\mathrm{G})$ & $\mathrm{NA}$ & -- & -- & $\mathrm{NA}$ & $0.86(G)$ & $\mathrm{NA}$ & -- & -- & $2.17(\mathrm{~J})$ & $\mathrm{NA}$ & $1.24(\mathrm{~J})$ & $\mathrm{NA}$ & $0.59(\mathrm{G})$ & $\mathrm{NA}$ & -- \\
\hline & $322 \mathrm{C} 008$ & $2-3$ & NA & $1.79(\mathrm{G})$ & -- & NA & -- & NA & $1.18(\mathrm{G})$ & -- & $1.03(\mathrm{G})$ & NA & $2.17(\mathrm{~J})$ & NA & $1.4(\mathrm{~J})$ & NA & $0.63(\mathrm{G})$ & - \\
\hline & $322 \mathrm{C} 009$ & $5-6$ & $\mathrm{NA}$ & $1.3(\mathrm{G})$ & -- & NA & - & NA & $0.87(\mathrm{G})$ & - & -- & $\mathrm{NA}$ & $1.78(\mathrm{~J})$ & $\mathrm{NA}$ & $0.91(\mathrm{~J})$ & $\mathrm{NA}$ & $0.58(G)$ & -- \\
\hline \multirow{4}{*}{$\mathrm{C} 04$} & $322 \mathrm{C} 010$ & $0-0.5$ & $1.78(\mathrm{G})$ & $\mathrm{NA}$ & -- & -- & $\mathrm{NA}$ & $1.14(\mathrm{G})$ & $\mathrm{NA}$ & -- & -- & $1.84(\mathrm{~J})$ & NA & $0.95(\mathrm{~J})$ & NA & $0.48(G)$ & $\mathrm{NA}$ & -- \\
\hline & $322 \mathrm{C} 011$ & $4-5$ & $\mathrm{NA}$ & $2.04(G)$ & -- & NA & -- & $\mathrm{NA}$ & $1.35(\mathrm{G})$ & -- & -- & $\mathrm{NA}$ & $2.52(\mathrm{~J})$ & $\mathrm{NA}$ & $1.35(\mathrm{~J})$ & NA & $0.76(\mathrm{G})$ & -- \\
\hline & $322 \mathrm{C} 012$ & $7-8$ & $\mathrm{NA}$ & $1.59(\mathrm{G})$ & -- & NA & -- & $\mathrm{NA}$ & $1.29(\mathrm{G})$ & -- & -- & $\mathrm{NA}$ & $2.2(\mathrm{~J})$ & $\mathrm{NA}$ & $0.98(\mathrm{~J})$ & NA & $0.72(\mathrm{G})$ & -- \\
\hline & $322 \mathrm{C} 013$ & $7-8$ & $\mathrm{NA}$ & $1.86(G)$ & $\overline{--}$ & NA & $3.3(\mathrm{G})$ & $\mathrm{NA}$ & $1.23(\mathrm{G})$ & -- & -- & NA & $2.2(\mathrm{~J})$ & $\mathrm{NA}$ & $1.49(\mathrm{~J})$ & NA & $0.6(\mathrm{G})$ & -- \\
\hline \multirow{3}{*}{$\mathrm{C} 05$} & $322 \mathrm{C} 013 \mathrm{~A}$ & $0-0.5$ & $1.66(G)$ & NA & $4.64(\mathrm{~J})$ & -- & NA & $1.25(\mathrm{G})$ & NA & $\begin{array}{c}0.39 \\
(G, L T)\end{array}$ & -- & $2.39(\mathrm{~J})$ & NA & $1.22(\mathrm{~J})$ & NA & $0.61(\mathrm{G})$ & NA & -- \\
\hline & $322 \mathrm{C} 014$ & $2-3$ & $\mathrm{NA}$ & $1.9(G)$ & $1.66(\mathrm{~J})$ & NA & -- & $\mathrm{NA}$ & $0.84(\mathrm{G})$ & $2.86(G)$ & $0.76(G)$ & NA & $2.1(\mathrm{~J})$ & $\mathrm{NA}$ & $1.35(\mathrm{~J})$ & NA & $0.59(\mathrm{G})$ & -- \\
\hline & $322 \mathrm{C} 015$ & $5-6$ & $\mathrm{NA}$ & $2.67(\mathrm{G})$ & -- & NA & -- & $\mathrm{NA}$ & $1.4(\mathrm{G})$ & - & -- & $\mathrm{NA}$ & $2.4(\mathrm{~J})$ & $\mathrm{NA}$ & $1.51(\mathrm{~J})$ & $\mathrm{NA}$ & $0.63(\mathrm{G})$ & -- \\
\hline \multirow{3}{*}{$\mathrm{C} 06$} & $322 \mathrm{C} 016$ & $0-1$ & $\mathrm{NA}$ & -- & $2.51(\mathrm{~J})$ & NA & -- & $\mathrm{NA}$ & -- & $3.03(\mathrm{G})$ & -- & NA & $1.07(\mathrm{~J})$ & $\mathrm{NA}$ & -- & $\mathrm{NA}$ & $0.48(G)$ & -- \\
\hline & $322 \mathrm{C} 017$ & $3-4$ & $\mathrm{NA}$ & -- & $3.91(\mathrm{~J})$ & NA & -- & $\mathrm{NA}$ & -- & $0.84(\mathrm{G})$ & -- & NA & $1.11(\mathrm{~J})$ & $\mathrm{NA}$ & $0.97(\mathrm{~J})$ & $\mathrm{NA}$ & $0.52(\mathrm{G})$ & - \\
\hline & $322 \mathrm{C} 018$ & $5-6$ & NA & - & $2.06(\mathrm{~J})$ & NA & -- & NA & $0.92(G)$ & $2.97(\mathrm{G})$ & -- & NA & $1.44(\mathrm{~J})$ & $\mathrm{NA}$ & $1.04(\mathrm{~J})$ & NA & $0.57(\mathrm{G})$ & -- \\
\hline
\end{tabular}


Table A.5-7

Soil Sample Results for Gamma-Emitting Radionuclides Detected Above Minimum Reporting Limits at CAS 03-20-05, Injection Well (Page 2 of 5 )

\begin{tabular}{|c|c|c|c|c|c|c|c|c|c|c|c|c|c|c|c|c|c|c|}
\hline \multirow[b]{2}{*}{$\begin{array}{l}\text { Sample } \\
\text { Location }\end{array}$} & \multirow[b]{2}{*}{$\begin{array}{c}\text { Sample } \\
\text { Number }\end{array}$} & \multirow[b]{2}{*}{$\begin{array}{c}\text { Depth } \\
\text { (ft bgs) }\end{array}$} & \multicolumn{16}{|c|}{ Contaminants of Potential Concern (pCi/g) } \\
\hline & & & \multicolumn{2}{|c|}{ 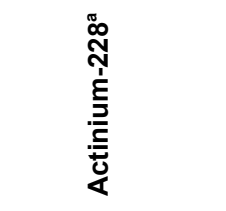 } & \multirow{3}{*}{ 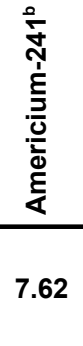 } & \multicolumn{2}{|c|}{ 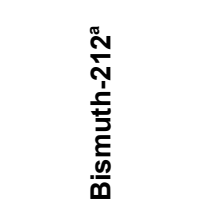 } & \multicolumn{2}{|c|}{ 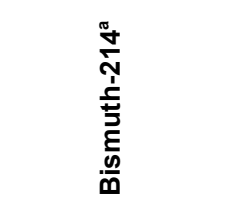 } & \multirow{3}{*}{ 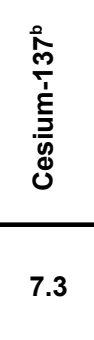 } & \multirow{3}{*}{ 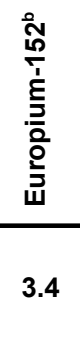 } & \multicolumn{2}{|c|}{ 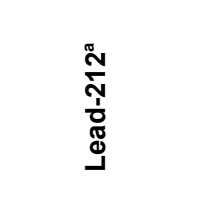 } & \multicolumn{2}{|c|}{ 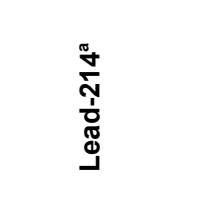 } & \multicolumn{2}{|c|}{ 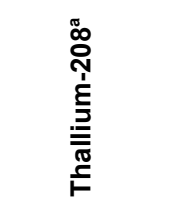 } & \multirow{3}{*}{ 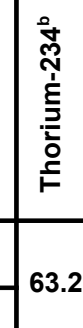 } \\
\hline \multicolumn{3}{|c|}{ Preliminary Action Levels } & 5 & 15 & & 5 & 15 & 5 & 15 & & & 5 & 15 & 5 & 15 & 5 & 15 & \\
\hline \multicolumn{3}{|c|}{ Depth bgs $(\mathrm{cm})$} & $<15$ & $>15$ & & $<15$ & $>15$ & $<15$ & $>15$ & & & $<15$ & $>15$ & $<15$ & $>15$ & $<15$ & $>15$ & \\
\hline \multirow{6}{*}{$\mathrm{C} 07$} & $\overline{322 \mathrm{C} 019}$ & $0-2$ & $\overline{\mathrm{NA}}$ & $\overline{---}$ & $\overline{---}$ & $\overline{N A}$ & $\overline{---}$ & NA & $\overline{---}$ & $2(\mathrm{G})$ & $\overline{---}$ & NA & 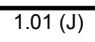 & $\overline{\mathrm{NA}}$ & $\overline{---}$ & NA & $\overline{---}$ & $\overline{---}$ \\
\hline & $322 \mathrm{C} 020$ & $3-4$ & NA & -- & $19.7(\mathrm{~J})$ & NA & -- & NA & -- & $4.23(G)$ & -- & NA & $1.5(\mathrm{~J})$ & $\mathrm{NA}$ & -- & NA & -- & -- \\
\hline & $322 \mathrm{C} 021$ & $5-6$ & NA & -- & $11.9(\mathrm{~J})$ & NA & -- & NA & -- & $10.1(G)$ & -- & NA & $1.34(\mathrm{~J})$ & $\mathrm{NA}$ & $0.98(\mathrm{~J})$ & $\mathrm{NA}$ & -- & -- \\
\hline & $322 \mathrm{C} 091$ & $14-15$ & NA & $1.69(\mathrm{G})$ & -- & NA & -- & NA & $0.83(\mathrm{G}, \mathrm{J})$ & -- & - & NA & $1.83(\mathrm{~J})$ & NA & $1.02(\mathrm{G}, \mathrm{J})$ & NA & $0.56(\mathrm{G})$ & -- \\
\hline & $322 \mathrm{C} 092$ & $19-20$ & NA & $1.74(\mathrm{G})$ & -- & NA & $2.9(\mathrm{G})$ & NA & $1.07(\mathrm{G}, \mathrm{J})$ & -- & -- & NA & $2.11(\mathrm{~J})$ & $\mathrm{NA}$ & $1.4(G, J)$ & $\mathrm{NA}$ & $0.73(G)$ & -- \\
\hline & $322 \mathrm{C} 093$ & $24-25$ & NA & $1.5(\mathrm{G})$ & -- & NA & -- & $\mathrm{NA})$ & $1.14(\mathrm{G}, \mathrm{J})$ & -- & -- & NA & $2.18(\mathrm{~J})$ & $\mathrm{NA}$ & $1.42(\mathrm{G}, \mathrm{J})$ & $\mathrm{NA}$ & $0.59(G)$ & $4.8(\mathrm{~J})$ \\
\hline \multirow{13}{*}{$\mathrm{C} 08$} & $322 \mathrm{C} 024$ & $0-2$ & NA & -- & -- & NA & - & NA & - & $2.19(\mathrm{G})$ & $\begin{array}{c}1.31 \\
(\mathrm{G}, \mathrm{TI})\end{array}$ & NA & $1.39(\mathrm{~J})$ & NA & $0.95(\mathrm{~J})$ & NA & $0.58(\mathrm{G})$ & - \\
\hline & $322 \mathrm{C} 025$ & $9-10$ & NA & -- & -- & NA & -- & NA & 1.15 & -- & -- & NA & 1.44 & $\mathrm{NA}$ & 0.93 & $\mathrm{NA}$ & 0.6 & -- \\
\hline & $322 \mathrm{C} 026$ & $20-21$ & NA & -- & -- & NA & -- & NA & -- & - & - & NA & $1.68(\mathrm{~J})$ & NA & $0.95(\mathrm{~J})$ & $\mathrm{NA}$ & -- & - \\
\hline & $322 \mathrm{C} 027$ & $30-31$ & NA & $1.5(\mathrm{G})$ & -- & NA & -- & NA & $0.9(G)$ & -- & -- & NA & $1.88(\mathrm{~J})$ & $\mathrm{NA}$ & $0.98(\mathrm{~J})$ & $\mathrm{NA}$ & -- & -- \\
\hline & $322 \mathrm{C} 028$ & $40-41$ & NA & $1.71(\mathrm{G})$ & -- & NA & -- & NA & -- & -- & -- & NA & $1.87(\mathrm{~J})$ & $\mathrm{NA}$ & $0.86(\mathrm{~J})$ & $\mathrm{NA}$ & $0.46(G)$ & -- \\
\hline & $322 \mathrm{C} 029$ & $50-51$ & NA & -- & -- & NA & -- & NA & -- & -- & -- & NA & 1.66 & $\mathrm{NA}$ & 0.81 & $\mathrm{NA}$ & -- & -- \\
\hline & $322 \mathrm{C} 030$ & $60-61$ & NA & -- & -- & NA & -- & NA & - & - & - & NA & $1.43(\mathrm{~J})$ & $\mathrm{NA}$ & $0.79(\mathrm{~J})$ & $\mathrm{NA}$ & $0.49(G)$ & - \\
\hline & $322 \mathrm{C} 031$ & $70-71$ & NA & $1.91(\mathrm{G})$ & -- & NA & -- & NA & -- & - & - & NA & $1.4(\mathrm{~J})$ & $\mathrm{NA}$ & $1.18(\mathrm{~J})$ & $\mathrm{NA}$ & $0.5(\mathrm{G})$ & -- \\
\hline & $322 \mathrm{C} 032$ & $80-81$ & NA & $1.67(\mathrm{G})$ & -- & NA & -- & NA & -- & $\overline{--}$ & - & NA & $1.89(\mathrm{~J})$ & $\mathrm{NA}$ & $0.88(\mathrm{~J})$ & $\mathrm{NA}$ & $0.47(G)$ & -- \\
\hline & $322 \mathrm{C} 033$ & $91-92$ & NA & - & -- & NA & -- & NA & -- & - & -- & NA & $1.68(\mathrm{~J})$ & $\mathrm{NA}$ & $1.02(\mathrm{~J})$ & $\mathrm{NA}$ & $0.73(\mathrm{G})$ & -- \\
\hline & $322 \mathrm{C} 034$ & $100-101$ & NA & $2.02(\mathrm{G})$ & -- & NA & -- & NA & -- & -- & -- & NA & $1.65(\mathrm{~J})$ & $\mathrm{NA}$ & $1.21(\mathrm{~J})$ & $\mathrm{NA}$ & $0.81(\mathrm{G})$ & -- \\
\hline & $322 \mathrm{C} 035$ & $111-112$ & NA & -- & -- & NA & -- & NA & $1.47(\mathrm{G})$ & -- & -- & NA & $1.71(\mathrm{~J})$ & $\mathrm{NA}$ & $1.05(\mathrm{~J})$ & $\mathrm{NA}$ & $0.61(G)$ & -- \\
\hline & $322 \mathrm{C} 036$ & $122-123$ & NA & $2.23(\mathrm{G}, \mathrm{TI})$ & -- & NA & -- & NA & $1.22(\mathrm{G})$ & -- & -- & NA & $1.72(\mathrm{~J})$ & NA & $1.06(\mathrm{~J})$ & NA & $0.64(\mathrm{G})$ & -- \\
\hline
\end{tabular}


Table A.5-7

Soil Sample Results for Gamma-Emitting Radionuclides Detected Above Minimum Reporting Limits at CAS 03-20-05, Injection Well (Page 3 of 5 )

\begin{tabular}{|c|c|c|c|c|c|c|c|c|c|c|c|c|c|c|c|c|c|c|}
\hline \multirow[b]{2}{*}{$\begin{array}{l}\text { Sample } \\
\text { Location }\end{array}$} & \multirow[b]{2}{*}{$\begin{array}{l}\text { Sample } \\
\text { Number }\end{array}$} & \multirow[b]{2}{*}{$\begin{array}{c}\text { Depth } \\
\text { (ft bgs) }\end{array}$} & \multicolumn{16}{|c|}{ Contaminants of Potential Concern (pCi/g) } \\
\hline & & & \multicolumn{2}{|c|}{ 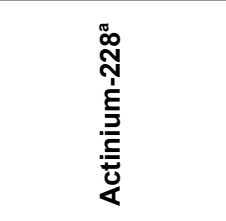 } & 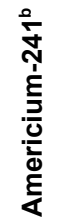 & \multicolumn{2}{|c|}{ 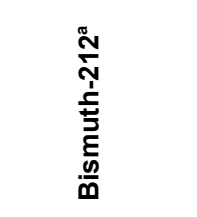 } & \multicolumn{2}{|c|}{ 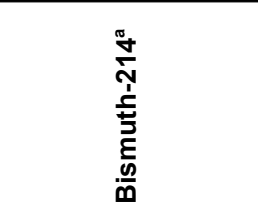 } & \multirow{3}{*}{ 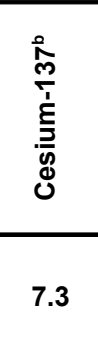 } & \multirow{3}{*}{ 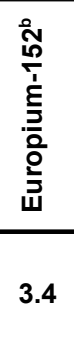 } & \multicolumn{2}{|c|}{ 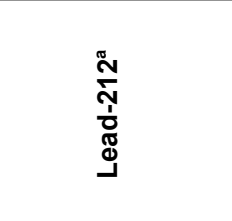 } & \multicolumn{2}{|c|}{ 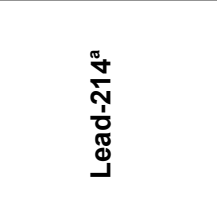 } & \multicolumn{2}{|c|}{ 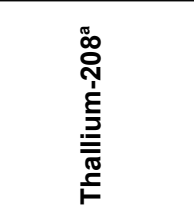 } & \multirow{3}{*}{ 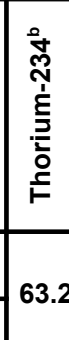 } \\
\hline Prelimin & action & Levels & 5 & 15 & \multirow{2}{*}{7.62} & 5 & 15 & 5 & 15 & & & 5 & 15 & 5 & 15 & 5 & 15 & \\
\hline \multicolumn{3}{|c|}{ Depth bgs (cm) } & $<15$ & $>15$ & & $<15$ & $>15$ & $<15$ & $>15$ & & & $<15$ & $>15$ & $<15$ & $>15$ & $<15$ & $>15$ & \\
\hline \multirow{14}{*}{$\cos$} & $322 \mathrm{C} 037$ & $\overline{0-0.5}$ & $\overline{1.68(\mathrm{G})}$ & $\overline{\mathrm{NA}}$ & $\overline{---}$ & $\overline{---}$ & $\overline{N A}$ & $\overline{1.2(\mathrm{G})}$ & $\overline{\mathrm{NA}}$ & $\overline{0.6(G)}$ & $\overline{--}$ & $\overline{\overline{1.78(\mathrm{~J})}}$ & $\overline{\mathrm{NA}}$ & $1.2(\mathrm{~J})$ & $\overline{\mathrm{NA}}$ & $\overline{0.59(\mathrm{G})}$ & $\overline{\mathrm{NA}}$ & $\overline{--}$ \\
\hline & $322 \mathrm{C} 038$ & $0-0.5$ & $1.62(\mathrm{G})$ & $\mathrm{NA}$ & -- & -- & NA & 1.29 (G) & NA & $0.71(\mathrm{G})$ & -- & $1.79(\mathrm{~J})$ & NA & $1.17(\mathrm{~J})$ & NA & $0.49(\mathrm{G})$ & NA & -- \\
\hline & $322 \mathrm{C} 042$ & $10-11$ & $\mathrm{NA}$ & $1.95(\mathrm{G})$ & -- & $\mathrm{NA}$ & -- & $\mathrm{NA}$ & $1.18(\mathrm{G})$ & -- & -- & NA & $2.17(\mathrm{~J})$ & NA & $1.06(\mathrm{~J})$ & NA & $0.75(\mathrm{G})$ & -- \\
\hline & $322 \mathrm{C} 043$ & $20-21$ & $\mathrm{NA}$ & $1.57(\mathrm{G})$ & -- & $\mathrm{NA}$ & -- & $\mathrm{NA}$ & $0.88(\mathrm{G})$ & -- & -- & NA & $2.02(\mathrm{~J})$ & NA & $1.17(\mathrm{~J})$ & NA & $0.67(\mathrm{G})$ & -- \\
\hline & $322 \mathrm{C} 044$ & $30-31$ & $\mathrm{NA}$ & $1.79(\mathrm{G})$ & - & $\mathrm{NA}$ & - & $\mathrm{NA}$ & $1.12(\mathrm{G})$ & - & $\overline{--}$ & $\mathrm{NA}$ & $1.94(\mathrm{~J})$ & $\mathrm{NA}$ & $1.11(\mathrm{~J})$ & $\mathrm{NA}$ & $0.42(G)$ & $\overline{--}$ \\
\hline & $322 \mathrm{C} 045$ & $40-41$ & $\mathrm{NA}$ & $1.7(\mathrm{G})$ & $\overline{--}$ & NA & -- & $\mathrm{NA}$ & $1.27(\mathrm{G})$ & -- & $\overline{--}$ & $\overline{N A}$ & $2.11(\mathrm{~J})$ & $\overline{\mathrm{NA}}$ & $1.17(\mathrm{~J})$ & $\overline{N A}$ & $0.7(\mathrm{G})$ & -- \\
\hline & $322 \mathrm{C} 046$ & $51-52$ & $\mathrm{NA}$ & $1.75(\mathrm{G})$ & -- & NA & -- & $\mathrm{NA}$ & $1.2(\mathrm{G})$ & -- & -- & $\mathrm{NA}$ & $1.99(\mathrm{~J})$ & $\mathrm{NA}$ & $1.31(\mathrm{~J})$ & NA & $0.63(G)$ & -- \\
\hline & $322 \mathrm{C} 047$ & $60-61$ & $\mathrm{NA}$ & $1.32(\mathrm{G})$ & -- & NA & -- & $\mathrm{NA}$ & $0.86(\mathrm{G})$ & -- & -- & NA & $1.48(\mathrm{~J})$ & $\mathrm{NA}$ & $0.7(\mathrm{~J})$ & NA & $0.55(\mathrm{G})$ & -- \\
\hline & $322 \mathrm{C} 048$ & $70-71$ & $\mathrm{NA}$ & $1.75(\mathrm{G})$ & -- & NA & -- & $\mathrm{NA}$ & $1.02(\mathrm{G})$ & -- & -- & $\mathrm{NA}$ & $2.19(\mathrm{~J})$ & $\mathrm{NA}$ & $1.23(\mathrm{~J})$ & $\mathrm{NA}$ & $0.56(G)$ & -- \\
\hline & $322 \mathrm{C} 049$ & $81-82$ & $\mathrm{NA}$ & $1.64(\mathrm{G})$ & -- & NA & -- & $\mathrm{NA}$ & $1.52(\mathrm{G})$ & -- & $\overline{--}$ & $\overline{N A}$ & $2.23(\mathrm{~J})$ & $\overline{N A}$ & $1.5(\mathrm{~J})$ & $\overline{N A}$ & $0.67(\mathrm{G})$ & -- \\
\hline & $322 \mathrm{C} 050$ & $92-93$ & $\mathrm{NA}$ & - & -- & NA & - & $\mathrm{NA}$ & $1.58(\mathrm{G})$ & - & $\overline{--}$ & $\overline{N A}$ & $2.05(\mathrm{~J})$ & $\overline{N A}$ & $1.31(\mathrm{~J})$ & $\mathrm{NA}$ & $0.48(G)$ & -- \\
\hline & $322 \mathrm{C} 051$ & $101-102$ & $\mathrm{NA}$ & -- & -- & NA & -- & $\mathrm{NA}$ & $1.27(\mathrm{G})$ & -- & -- & NA & $1.53(\mathrm{~J})$ & NA & $1.25(\mathrm{~J})$ & $\overline{\mathrm{NA}}$ & $0.58(G)$ & -- \\
\hline & $322 \mathrm{C} 052$ & 111 - 112 & $\mathrm{NA}$ & -- & -- & NA & -- & $\mathrm{NA}$ & -- & -- & -- & NA & $1.57(\mathrm{~J})$ & NA & $1.03(\mathrm{~J})$ & NA & $0.55(\mathrm{G})$ & -- \\
\hline & $322 \mathrm{C} 053$ & $121-122$ & $\overline{N A}$ & -- & $\overline{--}$ & NA & -- & $\overline{N A}$ & $1.16(\mathrm{G})$ & -- & -- & NA & $1.5(\mathrm{~J})$ & $\overline{N A}$ & $0.91(\mathrm{~J})$ & $\overline{N A}$ & $0.55(\mathrm{G})$ & -- \\
\hline
\end{tabular}


Table A.5-7

Soil Sample Results for Gamma-Emitting Radionuclides Detected Above Minimum Reporting Limits at CAS 03-20-05, Injection Well (Page 4 of 5 )

\begin{tabular}{|c|c|c|c|c|c|c|c|c|c|c|c|c|c|c|c|c|c|c|}
\hline \multirow[b]{2}{*}{$\begin{array}{l}\text { Sample } \\
\text { Location }\end{array}$} & \multirow[b]{2}{*}{$\begin{array}{l}\text { Sample } \\
\text { Number }\end{array}$} & \multirow[b]{2}{*}{$\begin{array}{c}\text { Depth } \\
\text { (ft bgs) }\end{array}$} & \multicolumn{16}{|c|}{ Contaminants of Potential Concern (pCi/g) } \\
\hline & & & \multicolumn{2}{|c|}{ 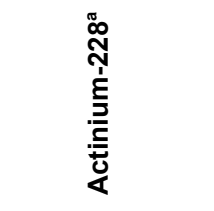 } & 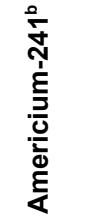 & \multicolumn{2}{|c|}{ 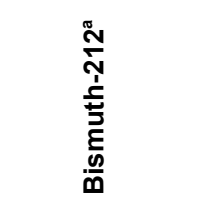 } & \multicolumn{2}{|c|}{ 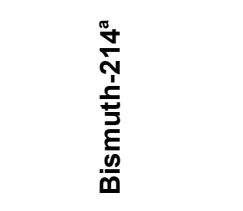 } & \multirow{3}{*}{ 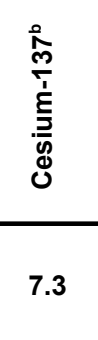 } & \multirow{3}{*}{ 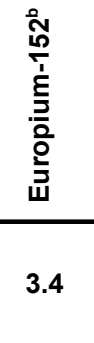 } & \multicolumn{2}{|c|}{ 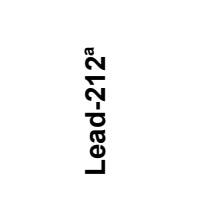 } & \multicolumn{2}{|c|}{ 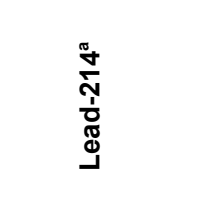 } & \multicolumn{2}{|c|}{ 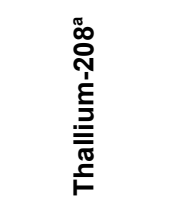 } & \multirow{3}{*}{ 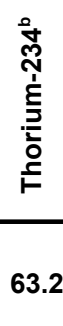 } \\
\hline Prelimin & iry Action & Levels & 5 & 15 & \multirow{2}{*}{7.62} & 5 & 15 & 5 & 15 & & & 5 & 15 & 5 & 15 & 5 & 15 & \\
\hline \multicolumn{3}{|c|}{ Depth bgs $(\mathrm{cm})$} & $<15$ & $>15$ & & $<15$ & $>15$ & $<15$ & $>15$ & & & $<15$ & $>15$ & $<15$ & $>15$ & $<15$ & $>15$ & \\
\hline \multirow{12}{*}{ C10 } & $322 \mathrm{C} 056$ & $1-2$ & NA & $\overline{--}$ & $\overline{---}$ & NA & $\overline{--}$ & NA & $\overline{--}$ & $\overline{---}$ & $\overline{---}$ & NA & $1.47(\mathrm{~J})$ & NA & $0.84(\mathrm{~J})$ & $\overline{\mathrm{NA}}$ & $0.41(\mathrm{G})$ & $\overline{--}$ \\
\hline & $322 \mathrm{C} 057$ & $10-11$ & NA & 1.34 & -- & NA & -- & NA & 0.92 & -- & -- & NA & 1.66 & NA & 0.91 & NA & 0.41 & -- \\
\hline & $322 \mathrm{C} 058$ & $21-22$ & NA & 1.66 & -- & NA & -- & NA & 0.9 & -- & -- & NA & 1.62 & NA & 0.98 & $\mathrm{NA}$ & 0.57 & -- \\
\hline & $322 \mathrm{C} 059$ & $30-31$ & NA & $1.41(\mathrm{G})$ & -- & NA & -- & NA & -- & -- & -- & NA & $1.41(\mathrm{~J})$ & NA & $0.78(\mathrm{~J})$ & $\mathrm{NA}$ & $0.37(\mathrm{G})$ & -- \\
\hline & $322 \mathrm{C} 060$ & $41-42$ & NA & -- & -- & NA & -- & NA & $1.09(\mathrm{G})$ & -- & -- & NA & $1.65(\mathrm{~J})$ & NA & $1.29(\mathrm{~J})$ & $\mathrm{NA}$ & $0.52(\mathrm{G})$ & -- \\
\hline & $322 \mathrm{C} 061$ & $51-52$ & NA & -- & -- & NA & -- & NA & -- & -- & -- & NA & $1.38(\mathrm{~J})$ & NA & $0.92(\mathrm{~J})$ & $\mathrm{NA}$ & $0.51(\mathrm{G})$ & -- \\
\hline & 322C062 & $60-61$ & NA & -- & -- & NA & -- & NA & 0.95 & -- & -- & NA & 1.32 & NA & 0.9 & $\mathrm{NA}$ & 0.54 & -- \\
\hline & $322 \mathrm{C} 063$ & $71-72$ & NA & $1.42(\mathrm{TI})$ & -- & NA & -- & NA & -- & -- & -- & NA & 1.38 & NA & 0.94 & $\mathrm{NA}$ & - & $\overline{--}$ \\
\hline & $322 \mathrm{C} 064$ & $81-82$ & NA & $1.48(G)$ & -- & NA & -- & NA & -- & -- & -- & NA & $1.92(\mathrm{~J})$ & NA & $0.96(\mathrm{~J})$ & NA & $0.54(\mathrm{G})$ & -- \\
\hline & $322 \mathrm{C} 065$ & $81-82$ & NA & $1.49(\mathrm{G})$ & -- & NA & -- & NA & -- & -- & -- & NA & $2.06(\mathrm{~J})$ & NA & $0.92(\mathrm{~J})$ & $\mathrm{NA}$ & $0.39(\mathrm{G})$ & - \\
\hline & $322 \mathrm{C} 066$ & $91-92$ & NA & 1.71 & -- & NA & -- & NA & 0.84 & -- & -- & NA & 1.44 & NA & 0.86 & $\mathrm{NA}$ & 0.4 & -- \\
\hline & $322 \mathrm{C} 067$ & $101-102$ & NA & $1.92(G)$ & -- & NA & -- & NA & $1.18(G)$ & -- & -- & NA & $1.8(\mathrm{~J})$ & NA & $1.25(\mathrm{~J})$ & NA & $0.61(G)$ & -- \\
\hline \multirow{4}{*}{ C11 } & $322 \mathrm{C} 068$ & $0-1$ & NA & $1.95(\mathrm{G})$ & $2.17(\mathrm{~J})$ & NA & -- & NA & $1.35(\mathrm{G})$ & $1.04(\mathrm{G})$ & $1.3(\mathrm{G})$ & NA & $2.14(\mathrm{~J})$ & NA & $1.43(\mathrm{~J})$ & $\mathrm{NA}$ & $0.74(G)$ & - \\
\hline & $322 \mathrm{C} 069$ & $49-50$ & NA & $1.5(\mathrm{G})$ & -- & NA & -- & NA & $1.02(\mathrm{G})$ & -- & -- & NA & $1.84(\mathrm{~J})$ & NA & $1.23(\mathrm{~J})$ & $\mathrm{NA}$ & $0.66(\mathrm{G})$ & -- \\
\hline & $322 \mathrm{C} 070$ & $59-60$ & NA & $1.68(G)$ & -- & NA & -- & NA & $0.95(\mathrm{G})$ & -- & -- & NA & $1.87(\mathrm{~J})$ & NA & $0.97(\mathrm{~J})$ & NA & $0.51(G)$ & -- \\
\hline & $322 \mathrm{C} 071$ & $69-70$ & NA & $1.92(\mathrm{G})$ & -- & NA & -- & NA & $1.14(\mathrm{G})$ & -- & -- & NA & $2.14(\mathrm{~J})$ & NA & $1.2(\mathrm{~J})$ & NA & $0.63(\mathrm{G})$ & -- \\
\hline
\end{tabular}


Table A.5-7

Soil Sample Results for Gamma-Emitting Radionuclides Detected Above Minimum Reporting Limits at CAS 03-20-05, Injection Well (Page 5 of 5 )

\begin{tabular}{|c|c|c|c|c|c|c|c|c|c|c|c|c|c|c|c|c|c|c|}
\hline \multirow[b]{2}{*}{$\begin{array}{c}\text { Sample } \\
\text { Location }\end{array}$} & \multirow[b]{2}{*}{$\begin{array}{l}\text { Sample } \\
\text { Number }\end{array}$} & \multirow[b]{2}{*}{$\begin{array}{l}\text { Depth } \\
\text { (ft bgs) }\end{array}$} & \multicolumn{16}{|c|}{ Contaminants of Potential Concern (pCi/g) } \\
\hline & & & \multicolumn{2}{|c|}{ 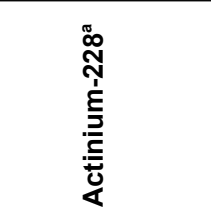 } & 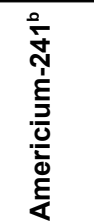 & \multicolumn{2}{|c|}{ 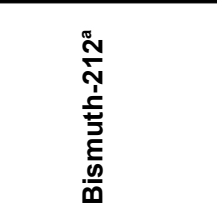 } & \multicolumn{2}{|c|}{ 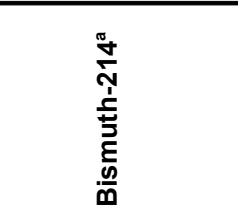 } & \multirow{3}{*}{ 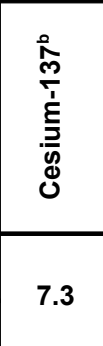 } & \multirow{3}{*}{ 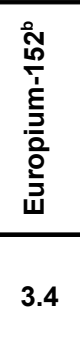 } & \multicolumn{2}{|c|}{ 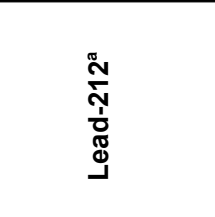 } & \multicolumn{2}{|c|}{ 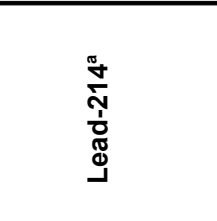 } & \multicolumn{2}{|c|}{ 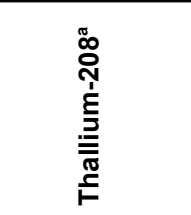 } & \multirow{3}{*}{ 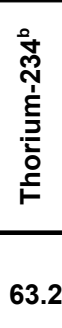 } \\
\hline Prelimir & ary Action & Levels & 5 & 15 & \multirow{2}{*}{7.62} & 5 & 15 & 5 & 15 & & & 5 & 15 & 5 & 15 & 5 & 15 & \\
\hline \multicolumn{3}{|c|}{ Depth bgs (cm) } & $<15$ & $>15$ & & $<15$ & $>15$ & $<15$ & $>15$ & & & $<15$ & $>15$ & $<15$ & $>15$ & $<15$ & $>15$ & \\
\hline \multirow{4}{*}{$\mathrm{C} 12$} & $322 \mathrm{C} 072$ & $0-1$ & NA & $1.84(\mathrm{G})$ & $7.28(\mathrm{~J})$ & NA & -- & NA & $1.16(G)$ & $5.45(\mathrm{G})$ & $\begin{array}{c}0.91 \\
(\mathrm{G}, \mathrm{TI})\end{array}$ & NA & $1.88(\mathrm{~J})$ & NA & $1.23(\mathrm{~J})$ & NA & $0.56(G)$ & -- \\
\hline & $322 \mathrm{C} 073$ & $49-50$ & NA & $2.04(G)$ & -- & NA & -- & NA & 0.97 (G) & - & -- & NA & 2.1 (J) & NA & $1.21(\mathrm{~J})$ & $\mathrm{NA}$ & $0.68(\mathrm{G})$ & -- \\
\hline & $322 \mathrm{C} 074$ & $59-60$ & NA & $1.93(\mathrm{G})$ & -- & $\mathrm{NA}$ & -- & NA & $0.87(\mathrm{G})$ & -- & -- & $\mathrm{NA}$ & $1.95(\mathrm{~J})$ & NA & $1.14(\mathrm{~J})$ & $\mathrm{NA}$ & $0.54(\mathrm{G})$ & -- \\
\hline & $322 \mathrm{C} 075$ & $69-70$ & NA & $2.05(\mathrm{G})$ & -- & NA & -- & $\mathrm{NA}$ & $1.11(\mathrm{G})$ & -- & - & NA & $2.25(\mathrm{~J})$ & $\mathrm{NA}$ & $1.45(\mathrm{~J})$ & $\mathrm{NA}$ & $0.71(\mathrm{G})$ & -- \\
\hline \multirow{4}{*}{$\mathrm{C} 19$} & $322 \mathrm{C} 095$ & $9-10$ & NA & $1.88(\mathrm{G})$ & -- & NA & -- & NA & $1.08(\mathrm{G}, \mathrm{J})$ & -- & -- & NA & $1.92(\mathrm{~J})$ & $\mathrm{NA}$ & $1.04(\mathrm{G}, \mathrm{J})$ & $\mathrm{NA}$ & $0.49(\mathrm{G})$ & -- \\
\hline & $322 \mathrm{C} 100$ & $49-50$ & NA & $1.73(\mathrm{G})$ & -- & NA & -- & NA & $1.26(\mathrm{G}, \mathrm{J})$ & -- & -- & NA & $1.84(\mathrm{~J})$ & NA & $1.18(\mathrm{G}, \mathrm{J})$ & NA & $0.61(\mathrm{G})$ & -- \\
\hline & 322C101 & $59-60$ & NA & $1.64(\mathrm{G})$ & -- & NA & -- & NA & $1.09(\mathrm{G}, \mathrm{J})$ & -- & -- & NA & $1.97(\mathrm{~J})$ & NA & $1.1(\mathrm{G}, \mathrm{J})$ & NA & $0.65(\mathrm{G})$ & -- \\
\hline & 322C102 & $69-70$ & NA & $1.74(\mathrm{G})$ & -- & NA & $1.45(\mathrm{G})$ & NA & $1.05(\mathrm{G}, \mathrm{J})$ & -- & -- & NA & $2.00(\mathrm{~J})$ & NA & $1.02(\mathrm{G}, \mathrm{J})$ & NA & $0.52(\mathrm{G})$ & $2.3(\mathrm{~J})$ \\
\hline
\end{tabular}

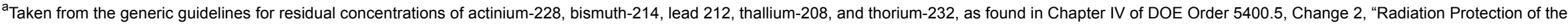

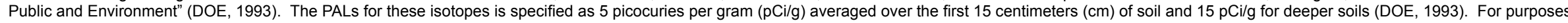
of this document, $15 \mathrm{~cm}$ is assumed to be equivalent to $0.5 \mathrm{ft}$ (6 inches); therefore, $5 \mathrm{pCi} / \mathrm{g}$ represents the PALs for these radionuclides in the surface soil ( 0 to $0.5 \mathrm{ft}$ depth).

${ }^{\mathrm{b}}$ Taken from the construction, commercial, industrial land use scenario in Table 2.1 of the NCRP Report No. 129, Recommended Screening Limits for Contaminated Surface Soil and Review Factors Relevant to Site-Specific Studies (NCRP, 1999). The values provided in this source document were scaled to a 15-mrem/yr dose.

$\mathrm{ft}$ bgs $=$ Feet below ground surface

$\mathrm{cm}=$ Centimeter

$\mathrm{pCi} / \mathrm{g}=$ Picocuries per gram

$--=$ Not detected above minimum reporting limits

$>=$ Greater than

$<=$ Less than

$\mathrm{G}=$ Sample density differs by more than 15 percent of laboratory control sample density.

$\mathrm{TI}=$ Tentatively identified

Estimated value. Qualifier added to laboratory data; record accepted. Sample does not meet counting geometry requirements.

LT $=$ Result is less than the requested minimum detectable concentration, greater than the specific minimum detectable concentration.
NA $=$ Not applicable 
to be confined to within the injection well casing. This is established by sample results for samples collected at locations C04, C08, C12, and C19 (Figure A.5-4).

\section{A.5.2.5.7 Plutonium}

Analytical results for plutonium in soil samples collected at CAS 03-20-05, that exceeded MDCs are presented in Table A.5-8. Plutonium contamination above PALs was found in two patterns at this site (i.e., surface contamination and contamination within the injection well vault).

Surface plutonium contamination was identified at four sample locations at concentrations above the PAL. Sample 322C038 at sample location C09 indicated a plutonium-239 result of $37.8 \mathrm{pCi} / \mathrm{g}$ at a depth of 0 to $1 \mathrm{ft}$ bgs. Samples collected around and beneath this location were below the PAL. Sample 322C079 at sample location C14 indicated a plutonium-239 result of $44.2 \mathrm{pCi} / \mathrm{g}$ at a depth of 0 to $0.5 \mathrm{pCi} / \mathrm{g} \mathrm{ft}$ bgs. Samples collected around and beneath this location were below the PAL. Sample 322C024 at sample location C08 indicated a plutonium-239 result of $40.4 \mathrm{pCi} / \mathrm{g}$ at a depth of 0 to $2 \mathrm{ft}$ bgs. Samples collected below this location were below the PAL; however, sample 322C078 at the adjacent sample location (C18) indicated a plutonium-239 result of $8.3 \mathrm{pCi} / \mathrm{g}$ at a depth of 0 to $0.5 \mathrm{ft}$ bgs. All of these were surface samples collected outside the injection well casing and are believed to be the result of deposition from atmospheric testing; therefore, the plutonium is not considered to be a COC detection at these locations. However, as a best management practice approximately $1 \mathrm{ft}^{3}$ of soil was removed from each of these locations and drummed for management as waste to mitigate potential personnel exposures. Verification samples were collected; however, these sample results are still pending and will be reported in the Final CADD.

Samples 322C020 and 322C021 at sample location C07 (inside the injection well vault) indicated plutonium-239 results of 15 and $29.1 \mathrm{pCi} / \mathrm{g}$ at depths of 3 to $4 \mathrm{ft}$ bgs and 5 to $6 \mathrm{ft}$ bgs, respectively. These detections are bounded laterally by uncontaminated sample results at locations C04, C08, C12, and C19 (Figure A.5-4). Additional samples were collected to determine the vertical extent of contamination. Samples collected below the original samples indicate the radiological contamination ends prior to $14 \mathrm{ft}$ bgs. Readings at this depth and those below this depth indicate a deficiency of the radiological contaminants relative to background levels. 


\section{A.5.2.5.8 Strontium-90}

Analytical results for Strontium-90 in soil samples collected at CAS 03-20-05, that exceeded MDCs are presented in Table A.5-8. Strontium-90 was not detected above the PAL.

\section{A.5.2.5.9 Uranium}

Analytical results for gamma-emitting radionuclides in soil samples collected at CAS 03-20-05, that exceeded MDCs are presented in Table A.5-8. Uranium was not detected above the PAL.

\section{A.5.2.6 Contaminants of Concern}

The COCs lead, Aroclor-1254, TPH-DRO, cesium-137, americium-141, and plutonium-239 were identified in samples taken from the injection well. In addition, Aroclor-1254 and TPH-DRO was identified at several surface locations at CAS 03-20-05. Lead and cadmium were identified above the FAL for samples within the injection well soils (cadmium was above the RCRA TCLP minimum for the characteristic of toxicity in the surface samples of soils within the injection well). Samples collected around the outside of the injection well and from deeper locations within the injection well provide results below the FALs and RCRA TCLP maximums for these metals.

Aroclor-1254 was identified above the FAL at three locations, two within the injection well vault and one at a surface location outside the vault. The surface location was excavated to remove colocated $\mathrm{Pu}-239$ contamination.

Total petroleum hydrocarbon-DRO contamination was identified within the injection well vault soils, within soils collected at the depth of the bottom of the injection well sump, and at various surface locations outside the injection well at concentrations above the PAL.

The radionuclides cesium-137, americium-141, and plutonium-239 are contaminants of concern only as their release can be associated with operations that occurred at the BOP Shop. This association requires that their presence be associated with samples collected from the injection well soils as a result of direct deposition from the activities within the BOP Shop via underground piping. Surface deposition of plutonium-239 outside the injection well from atmospheric testing is not considered to be a COC for this CAS, as its origin is not associated with processes occurring at the BOP Shop. 
Table A.5-8

Soil Sample Results for Isotopes Detected Above Minimum Reporting Limits at CAS 03-20-05, Injection Well

(Page 1 of 7 )

\begin{tabular}{|c|c|c|c|c|c|c|c|c|}
\hline \multirow{2}{*}{$\begin{array}{l}\text { Sample } \\
\text { Location }\end{array}$} & \multirow{2}{*}{$\begin{array}{l}\text { Sample } \\
\text { Number }\end{array}$} & \multirow{2}{*}{$\begin{array}{c}\text { Depth } \\
\text { (ft bgs) }\end{array}$} & \multicolumn{6}{|c|}{ Contaminants of Potential Concern $(\mathrm{pCi} / \mathrm{g})$} \\
\hline & & & Plutonium-238 & Plutonium-239 & Strontium-90 & Uranium-234 & Uranium-235 & Uranium-238 \\
\hline \multicolumn{3}{|c|}{ Preliminary Action Levels ${ }^{a}$} & 7.78 & 7.62 & 503 & 85.9 & 10.5 & 63.2 \\
\hline \multirow{3}{*}{$\mathrm{C} 01$} & $322 \mathrm{C} 001$ & $0-0.5$ & 0.142 & 0.45 & -- & 1.02 & -- & 1.04 \\
\hline & $322 \mathrm{C} 002$ & $2-3$ & -- & -- & -- & 0.98 & -- & 0.89 \\
\hline & $322 \mathrm{C} 003$ & $4-5$ & -- & -- & -- & 1.12 & -- & 0.94 \\
\hline \multirow{3}{*}{$\mathrm{C} 02$} & $322 \mathrm{C} 004$ & $0-0.5$ & 0.348 & 2.82 & -- & 1.11 & 0.073 & 0.97 \\
\hline & $322 \mathrm{C} 005$ & $2-3$ & - & - & -- & 0.96 & -- & 0.97 \\
\hline & $322 \mathrm{C} 006$ & $5-6$ & -- & -- & -- & 0.94 & -- & 1.07 \\
\hline \multirow{3}{*}{$\mathrm{CO3}$} & $322 \mathrm{C} 007$ & $0-0.5$ & 0.73 & 2.59 & -- & 0.91 & -- & 1.06 \\
\hline & $322 \mathrm{C} 008$ & $2-3$ & 0.36 & 2.64 & -- & 0.95 & 0.054 & 1.14 \\
\hline & 322C009 & $5-6$ & -- & -- & -- & 0.89 & -- & 0.8 \\
\hline \multirow{4}{*}{$\mathrm{CO} 4$} & $322 \mathrm{C} 010$ & $0-0.5$ & 0.154 & 0.82 & -- & 0.92 & -- & 1.05 \\
\hline & $322 \mathrm{C} 011$ & $4-5$ & -- & -- & -- & 1.13 & 0.054 & 1.11 \\
\hline & $322 \mathrm{C} 012$ & $7-8$ & -- & -- & -- & 1.18 & -- & 0.98 \\
\hline & $322 \mathrm{C} 013$ & $7-8$ & -- & -- & -- & 0.96 & -- & 1.11 \\
\hline
\end{tabular}


Table A.5-8

Soil Sample Results for Isotopes Detected Above Minimum Reporting Limits at CAS 03-20-05, Injection Well

(Page 2 of 7 )

\begin{tabular}{|c|c|c|c|c|c|c|c|c|}
\hline \multirow{2}{*}{$\begin{array}{l}\text { Sample } \\
\text { Location }\end{array}$} & \multirow{2}{*}{$\begin{array}{l}\text { Sample } \\
\text { Number }\end{array}$} & \multirow{2}{*}{$\begin{array}{c}\text { Depth } \\
\text { (ft bgs) }\end{array}$} & \multicolumn{6}{|c|}{ Contaminants of Potential Concern (pCi/g) } \\
\hline & & & Plutonium-238 & Plutonium-239 & Strontium-90 & Uranium-234 & Uranium-235 & Uranium-238 \\
\hline \multicolumn{3}{|c|}{ Preliminary Action Levels ${ }^{a}$} & 7.78 & 7.62 & 503 & 85.9 & 10.5 & 63.2 \\
\hline \multirow{3}{*}{$\mathrm{C} 05$} & $322 \mathrm{C} 013 \mathrm{~A}$ & $0-0.5$ & 0.052 & 0.97 & -- & 0.94 & -- & 0.8 \\
\hline & $322 \mathrm{C} 014$ & $2-3$ & 0.47 & 2.77 & -- & 0.76 & -- & 0.87 \\
\hline & $322 \mathrm{C} 015$ & $5-6$ & -- & 0.143 & -- & 1.08 & 0.088 & 1.24 \\
\hline \multirow{3}{*}{$\mathrm{C} 06$} & $322 \mathrm{C} 016$ & $0-1$ & 0.143 & 2.29 & -- & 1.99 & 0.074 & 0.97 \\
\hline & $322 \mathrm{C} 017$ & $3-4$ & 0.274 & 2.29 & -- & 1.24 & -- & 0.96 \\
\hline & $322 \mathrm{C} 018$ & $5-6$ & 0.76 & 5.56 & $0.51(\mathrm{~J})^{\mathrm{b}}$ & 1.78 & -- & 1.18 \\
\hline \multirow{6}{*}{$\mathrm{C} 07$} & $322 \mathrm{C} 019$ & $0-2$ & 0.266 & 2.54 & -- & 1.63 & -- & 0.86 \\
\hline & $322 \mathrm{C} 020$ & $3-4$ & 1.27 & $15(\mathrm{~J})^{\mathrm{c}}$ & -- & 1.71 & 0.081 & 1.02 \\
\hline & $322 \mathrm{C} 021$ & $5-6$ & 0.95 & 29.1 & -- & 1.47 & -- & 0.94 \\
\hline & $322 \mathrm{C091}$ & $14-15$ & -- & -- & -- & 0.94 & -- & 0.86 \\
\hline & $322 \mathrm{C} 092$ & $19-20$ & -- & $0.044(\mathrm{LT})$ & -- & 1.29 & 0.075 & 1.22 \\
\hline & $322 \mathrm{C093}$ & $24-25$ & -- & -- & -- & 1.27 & 0.081 & 1.11 \\
\hline
\end{tabular}


Table A.5-8

Soil Sample Results for Isotopes Detected Above Minimum Reporting Limits at CAS 03-20-05, Injection Well

(Page 3 of 7)

\begin{tabular}{|c|c|c|c|c|c|c|c|c|}
\hline \multirow{2}{*}{$\begin{array}{l}\text { Sample } \\
\text { Location }\end{array}$} & \multirow{2}{*}{$\begin{array}{l}\text { Sample } \\
\text { Number }\end{array}$} & \multirow{2}{*}{$\begin{array}{c}\text { Depth } \\
\text { (ft bgs) }\end{array}$} & \multicolumn{6}{|c|}{ Contaminants of Potential Concern (pCi/g) } \\
\hline & & & Plutonium-238 & Plutonium-239 & Strontium-90 & Uranium-234 & Uranium-235 & Uranium-238 \\
\hline \multicolumn{3}{|c|}{ Preliminary Action Levels ${ }^{a}$} & 7.78 & 7.62 & 503 & 85.9 & 10.5 & 63.2 \\
\hline \multirow{14}{*}{$\mathrm{C} 08$} & $322 \mathrm{C} 024$ & $0-2$ & 2.29 & 40.4 & -- & 0.98 & -- & 0.93 \\
\hline & $322 \mathrm{C} 025$ & $9-10$ & -- & -- & -- & 1.32 & -- & 1.16 \\
\hline & $322 \mathrm{C} 026$ & $20-21$ & -- & -- & -- & 1.22 & 0.083 & 1.12 \\
\hline & $322 \mathrm{C} 027$ & $30-31$ & -- & -- & -- & 1.06 & 0.06 & 1.05 \\
\hline & $322 \mathrm{C} 028$ & $40-41$ & -- & -- & -- & 1.03 & 0.056 & 1.01 \\
\hline & $322 C 029$ & $50-51$ & -- & -- & -- & 1 & -- & 0.96 \\
\hline & $322 \mathrm{C} 030$ & $60-61$ & -- & -- & -- & 0.89 & -- & 1 \\
\hline & $322 \mathrm{C} 031$ & $70-71$ & -- & -- & -- & 1.07 & 0.075 & 1.05 \\
\hline & $322 \mathrm{C} 032$ & $80-81$ & -- & -- & -- & 1.09 & -- & 1.07 \\
\hline & $322 \mathrm{C} 033$ & $91-92$ & -- & -- & -- & 1.36 & -- & 1.46 \\
\hline & $322 \mathrm{C} 034$ & $100-101$ & -- & -- & -- & 1.35 & 0.082 & 1.24 \\
\hline & $322 \mathrm{C} 035$ & $111-112$ & -- & -- & -- & 1.19 & 0.09 & 1.27 \\
\hline & $322 \mathrm{C} 036$ & $122-123$ & -- & -- & -- & 1.11 & -- & 1.16 \\
\hline & $322 \mathrm{C} 105$ & $0.5-1.5$ & 0.283 & 4.29 & -- & -- & -- & -- \\
\hline
\end{tabular}


Table A.5-8

Soil Sample Results for Isotopes Detected Above Minimum Reporting Limits at CAS 03-20-05, Injection Well (Page 4 of 7 )

\begin{tabular}{|c|c|c|c|c|c|c|c|c|}
\hline \multirow{2}{*}{$\begin{array}{l}\text { Sample } \\
\text { Location }\end{array}$} & \multirow{2}{*}{$\begin{array}{l}\text { Sample } \\
\text { Number }\end{array}$} & \multirow{2}{*}{$\begin{array}{c}\text { Depth } \\
\text { (ft bgs) }\end{array}$} & \multicolumn{6}{|c|}{ Contaminants of Potential Concern $(\mathrm{pCi} / \mathrm{g})$} \\
\hline & & & Plutonium-238 & Plutonium-239 & Strontium-90 & Uranium-234 & Uranium-235 & Uranium-238 \\
\hline \multicolumn{3}{|c|}{ Preliminary Action Levels ${ }^{a}$} & 7.78 & 7.62 & 503 & 85.9 & 10.5 & 63.2 \\
\hline \multirow{16}{*}{ Co9 } & $322 \mathrm{C} 037$ & $0-0.5$ & 0.078 & 0.74 & -- & 0.84 & -- & 0.88 \\
\hline & $322 \mathrm{C} 038$ & $0-0.5$ & 0.55 & 37.8 & -- & 1.01 & 0.071 & 1.08 \\
\hline & $322 \mathrm{C} 042$ & $10-11$ & -- & -- & -- & 1.18 & -- & 1.04 \\
\hline & $322 \mathrm{C} 043$ & $20-21$ & -- & -- & -- & 0.94 & 0.068 & 0.94 \\
\hline & $322 \mathrm{C} 044$ & $30-31$ & -- & -- & -- & 0.99 & 0.076 & 1.08 \\
\hline & $322 \mathrm{C} 045$ & $40-41$ & -- & -- & -- & 1.16 & 0.069 & 1.04 \\
\hline & $322 \mathrm{C} 046$ & $51-52$ & -- & $0.046(\mathrm{LT})$ & -- & 1.1 & 0.089 & 1.12 \\
\hline & $322 \mathrm{C} 047$ & $60-61$ & -- & -- & -- & 0.82 & -- & 0.72 \\
\hline & $322 \mathrm{C} 048$ & $70-71$ & -- & -- & -- & 1 & -- & 0.98 \\
\hline & $322 \mathrm{C} 049$ & $81-82$ & -- & -- & -- & 1.05 & -- & 1.21 \\
\hline & $322 \mathrm{C} 050$ & $92-93$ & -- & -- & -- & 1.53 & 0.094 & 1.61 \\
\hline & $322 \mathrm{C} 051$ & $101-102$ & -- & -- & -- & 1.64 & 0.085 & 1.58 \\
\hline & $322 \mathrm{C} 052$ & $111-112$ & -- & -- & -- & 1.26 & 0.056 & 1.32 \\
\hline & $322 \mathrm{C} 053$ & $121-122$ & -- & -- & -- & 1.02 & -- & 1.07 \\
\hline & $322 C 089$ & $1-2$ & 1.4 & 4.69 & -- & -- & -- & -- \\
\hline & $322 \mathrm{C} 103$ & $0.5-1.5$ & -- & 0.24 & -- & -- & -- & -- \\
\hline
\end{tabular}


Table A.5-8

Soil Sample Results for Isotopes Detected Above Minimum Reporting Limits at CAS 03-20-05, Injection Well (Page 5 of 7 )

\begin{tabular}{|c|c|c|c|c|c|c|c|c|}
\hline \multirow{2}{*}{$\begin{array}{l}\text { Sample } \\
\text { Location }\end{array}$} & \multirow{2}{*}{$\begin{array}{l}\text { Sample } \\
\text { Number }\end{array}$} & \multirow{2}{*}{$\begin{array}{c}\text { Depth } \\
\text { (ft bgs) }\end{array}$} & \multicolumn{6}{|c|}{ Contaminants of Potential Concern (pCi/g) } \\
\hline & & & Plutonium-238 & Plutonium-239 & Strontium-90 & Uranium-234 & Uranium-235 & Uranium-238 \\
\hline \multicolumn{3}{|c|}{ Preliminary Action Levels ${ }^{a}$} & 7.78 & 7.62 & 503 & 85.9 & 10.5 & 63.2 \\
\hline \multirow{12}{*}{ C10 } & $322 \mathrm{C} 056$ & $1-2$ & 0.191 & 0.88 & -- & 0.93 & -- & 0.9 \\
\hline & $322 \mathrm{C} 057$ & $10-11$ & -- & -- & -- & 0.94 & -- & 1 \\
\hline & $322 C 058$ & $21-22$ & -- & -- & -- & 0.82 & 0.075 & 0.72 \\
\hline & $322 C 059$ & $30-31$ & -- & -- & -- & 1.03 & -- & 0.98 \\
\hline & $322 \mathrm{C} 060$ & $41-42$ & -- & -- & -- & 1.09 & 0.059 & 1.19 \\
\hline & $322 \mathrm{C} 061$ & $51-52$ & -- & -- & -- & 0.92 & 0.058 & 1 \\
\hline & $322 \mathrm{C} 062$ & $60-61$ & -- & -- & -- & 0.99 & -- & 1.04 \\
\hline & $322 \mathrm{C} 063$ & $71-72$ & -- & -- & -- & 0.95 & -- & 0.9 \\
\hline & $322 \mathrm{C} 064$ & $81-82$ & -- & -- & -- & 0.99 & -- & 1 \\
\hline & $322 \mathrm{C} 065$ & $81-82$ & -- & -- & -- & 0.97 & -- & 1.09 \\
\hline & $322 \mathrm{C} 066$ & $91-92$ & -- & -- & -- & 0.89 & -- & 1.02 \\
\hline & $322 \mathrm{C} 067$ & $101-102$ & -- & -- & -- & 1.32 & -- & 1.39 \\
\hline \multirow{4}{*}{ C11 } & $322 \mathrm{C} 068$ & $0-1$ & -- & 2.46 & -- & 1 & -- & 0.94 \\
\hline & $322 C 069$ & $49-50$ & -- & -- & -- & 1.05 & $0.033(\mathrm{LT})$ & 1.16 \\
\hline & $322 \mathrm{C} 070$ & $59-60$ & -- & -- & -- & 1.04 & $0.037(\mathrm{LT})$ & 1.08 \\
\hline & $322 \mathrm{C} 071$ & $69-70$ & -- & -- & -- & 1.13 & 0.073 & 1.09 \\
\hline
\end{tabular}


Table A.5-8

Soil Sample Results for Isotopes Detected Above Minimum Reporting Limits at CAS 03-20-05, Injection Well (Page 6 of 7 )

\begin{tabular}{|c|c|c|c|c|c|c|c|c|}
\hline \multirow{2}{*}{$\begin{array}{l}\text { Sample } \\
\text { Location }\end{array}$} & \multirow{2}{*}{$\begin{array}{l}\text { Sample } \\
\text { Number }\end{array}$} & \multirow{2}{*}{$\begin{array}{c}\text { Depth } \\
\text { (ft bgs) }\end{array}$} & \multicolumn{6}{|c|}{ Contaminants of Potential Concern $(\mathrm{pCi} / \mathrm{g})$} \\
\hline & & & Plutonium-238 & Plutonium-239 & Strontium-90 & Uranium-234 & Uranium-235 & Uranium-238 \\
\hline \multicolumn{3}{|c|}{ Preliminary Action Levels ${ }^{a}$} & 7.78 & 7.62 & 503 & 85.9 & 10.5 & 63.2 \\
\hline \multirow{4}{*}{$\mathrm{C} 12$} & $322 \mathrm{C} 072$ & $0-1$ & $0.199(J)^{c}$ & 0.97 & - & 0.92 & -- & 0.97 \\
\hline & $322 \mathrm{C073}$ & $49-50$ & -- & -- & -- & 0.99 & 0.057 & 0.98 \\
\hline & $322 \mathrm{C} 074$ & $59-60$ & -- & - & - & 0.97 & -- & 0.99 \\
\hline & $322 \mathrm{C} 075$ & $69-70$ & -- & -- & -- & 1.21 & 0.062 & 1.09 \\
\hline \multirow{3}{*}{$\mathrm{C} 13$} & $322 \mathrm{C} 076$ & $0-0.5$ & $0.042(\mathrm{LT})$ & 0.47 & -- & -- & -- & - \\
\hline & $322 \mathrm{C} 077$ & $0-0.5$ & $0.032(\mathrm{LT})$ & 0.46 & -- & -- & -- & - \\
\hline & $322 C 078$ & $1-2$ & 0.105 & 1.21 & -- & -- & -- & -- \\
\hline \multirow{3}{*}{ C14 } & 322C079 & $0-0.5$ & 1.42 & 44.2 & -- & -- & -- & -- \\
\hline & $322 \mathrm{C} 080$ & $1-2$ & 0.103 & 0.46 & -- & -- & -- & -- \\
\hline & $322 \mathrm{C} 104$ & $0.5-1.5$ & -- & 0.297 & -- & -- & - & -- \\
\hline \multirow{2}{*}{ C15 } & $322 \mathrm{C} 081$ & $0.5-1$ & 0.074 & 0.45 & -- & -- & -- & -- \\
\hline & $322 \mathrm{C} 082$ & $1-2$ & 0.055 & 0.6 & -- & -- & -- & -- \\
\hline \multirow{2}{*}{ C16 } & $322 \mathrm{C} 083$ & $0.5-1$ & -- & 0.303 & -- & -- & -- & -- \\
\hline & $322 \mathrm{C} 084$ & $1-2$ & -- & 0.57 & -- & -- & -- & -- \\
\hline \multirow{2}{*}{ C17 } & $322 \mathrm{C} 085$ & $0.5-1$ & -- & 0.248 & -- & -- & - & - \\
\hline & $322 \mathrm{C} 086$ & $1-2$ & 1.05 & 5.82 & -- & -- & -- & -- \\
\hline
\end{tabular}


Table A.5-8

Soil Sample Results for Isotopes Detected Above Minimum Reporting Limits at CAS 03-20-05, Injection Well

(Page 7 of 7 )

\begin{tabular}{|c|c|c|c|c|c|c|c|c|}
\hline \multirow{2}{*}{$\begin{array}{l}\text { Sample } \\
\text { Location }\end{array}$} & \multirow{2}{*}{$\begin{array}{l}\text { Sample } \\
\text { Number }\end{array}$} & \multirow{2}{*}{$\begin{array}{c}\text { Depth } \\
\text { (ft bgs) }\end{array}$} & \multicolumn{6}{|c|}{ Contaminants of Potential Concern (pCi/g) } \\
\hline & & & Plutonium-238 & Plutonium-239 & Strontium-90 & Uranium-234 & Uranium-235 & Uranium-238 \\
\hline \multicolumn{3}{|c|}{ Preliminary Action Levels ${ }^{a}$} & 7.78 & 7.62 & 503 & 85.9 & 10.5 & 63.2 \\
\hline \multirow{3}{*}{ C18 } & $322 \mathrm{C} 087$ & $0.5-1$ & 0.131 & 8.3 & -- & -- & -- & -- \\
\hline & $322 \mathrm{C} 088$ & $1-2$ & 0.73 & 2.97 & -- & -- & -- & -- \\
\hline & $322 C 106$ & $0.5-1.5$ & -- & 0.7 & -- & -- & -- & -- \\
\hline \multirow{4}{*}{ C19 } & 322C095 & $9-10$ & -- & -- & -- & 1.1 & -- & 1.09 \\
\hline & $322 \mathrm{C} 100$ & $49-50$ & -- & -- & -- & 1.09 & 0.051 & 1.18 \\
\hline & $322 \mathrm{C} 101$ & $59-60$ & -- & -- & -- & 0.97 & -- & 0.87 \\
\hline & $322 \mathrm{C} 102$ & $69-70$ & -- & -- & -- & 1.08 & 0.082 & 0.097 \\
\hline
\end{tabular}

Taken from the construction, commercial, industrial land use scenario in Table 2.1 of the NCRP Report No. 129 Recommended Screening Limits for Contaminated Surface Soil and Review Factors Relevant to Site-Specific Studies (NCRP, 1999). The values provided in this source document were scaled to a 15-mrem/yr dose.

${ }^{b}$ Qualifier added to laboratory data; record accepted. Laboratory control sample and/or laboratory control sample duplicate recovery outside control limits.

${ }^{\circ}$ Qualifier added to laboratory data; record accepted. Duplicate precision analysis (relative percent difference) outside control limits.

$\mathrm{ft}$ bgs = Feet below ground surface

$\mathrm{pCi} / \mathrm{g}=$ Picocuries per gram

$\mathrm{LT}=$ Result is less than the requested minimum detectable concentration, greater than the specific minimum detectable

concentration.

$--=$ Not detected above minimum reporting limits

$\mathrm{J}=$ Estimated value. 
No other COCs were identified at this site.

\section{A.5.3 Nature and Extent of Contamination}

Contamination found within the injection well casing is believed to be the result of processes that occurred within the BOP Shop, as the waste from the Shop was routed to the injection well via underground piping. Additional contamination may have resulted from direct dumping of waste into the injection well casing, as reported by interviewees.

Lead and cadmium contamination was restricted to the injection well vault soils and is bounded vertically by samples collected outside the injection well casing and by samples collected at sampling intervals beneath the contamination.

Aroclor-1254 contamination was limited to the surface soil samples collected within the injection well, and to one location outside the injection well. The contamination outside the injection well was excavated to remove colocated $\mathrm{Pu}-239$ contamination. Vertical extent of Aroclor-1254 contamination was defined by samples collected beneath the surface contamination.

Total petroleum hydrocarbon-DRO was found to be present at levels above the PAL in the soil within the injection well casing. Additional sampling to a depth of $25 \mathrm{ft}$ bgs indicated that TPH-DRO contamination continues to exist above the PAL, and is assumed to be connected to the TPH-DRO contamination associated with samples collected at $60 \mathrm{ft} \mathrm{bgs,} \mathrm{the} \mathrm{depth} \mathrm{of} \mathrm{the} \mathrm{injection} \mathrm{well} \mathrm{sump.}$

Total petroleum hydrocarbon-DRO was also identified at a depth of 60 to $61 \mathrm{ft}$ bgs at drilling locations immediately adjacent to the injection well. Sample 322C030 at sample location C08 indicated a TPH-DRO result of $730 \mathrm{ppm}$. Samples collected above and below this location were below the PAL for TPH-DRO. The source of the TPH-DRO contamination is believed to be the injection well sump, which was determined to end $62 \mathrm{ft}$ bgs. Additional sampling was performed to determine that the TPH-DRO contamination at this depth was not the result of a plume of contamination from the soils within the injection well vault. An additional sample location (C19) was chosen that was closer to the injection well than sample location C08. Location C19 would intercept the plume of contamination (if it existed as an inverted cone) from the injection well soils before the 60 to $61 \mathrm{ft}$ bgs interval was reached. The analytical results indicated that no contamination was 
encountered until the 60 to $61 \mathrm{ft}$ bgs interval was reached. At the 60 to $61 \mathrm{ft}$ interval the TPH-DRO concentration was determined to be $1,800 \mathrm{mg} / \mathrm{kg}$. It is assumed that the surface soil contamination is connected as a cylindrical plume until the bottom of the injection well sump is reached.

Also found above their respective PALs was cesium-137, americium-241, and plutonium-239. Subsequent sampling and analysis indicated that the concentrations of these radiological contaminants dropped to below their respective PALs prior to $14 \mathrm{ft}$ bgs.

\section{A.5.4 Revised Conceptual Site Model}

No variations in the conceptual site model were identified. However, a more conclusive statement can be made regarding the conceptual site model for the injection well itself. Contamination identified at the 60 to $61 \mathrm{ft}$ bgs interval originates from the bottom of the injection well sump, not from the soils within the injection well vault. The process that placed contaminants within the injection well vault allowed for the percolation of the heavier components (e.g., metals, radionuclides) within the soil surrounding the sump, while the lighter components of the BOP Shop effluent (e.g., petroleum hydrocarbons) were directed down the sump. The location of contaminants identified in the injection well are consistent with its intended design. This conception was realized, as only TPH-DRO was identified at the depth of the injection well sump, and metals and radionuclides were identified within the soils of the injection well vault. 


\section{A.6.0 Waste Management}

Investigation-derived waste (IDW) was generated during the field investigation activities of CAU 322. The waste streams generated include disposable personal protective equipment (PPE), plastic, disposable sampling equipment, soil and debris, and miscellaneous waste removed as best management practice during the investigation activities. Investigation-derived waste was segregated to the greatest extent possible and waste minimization techniques were integrated into the field activities to reduce the amount of waste generated. Controls were in place to minimize the use of hazardous materials and the unnecessary generation of hazardous and/or mixed waste.

Decontamination activities were planned and executed to minimize the volume of rinsate generated.

The amount, type, and source of waste placed into each drum was recorded in waste management logbooks. Potentially hazardous or potentially radioactive wastes generated during the investigation were placed in containers and labeled as "Hazardous Waste - Pending Analysis, or "Radioactive Waste Pending Analysis.” Three Hazardous Waste Accumulation Areas (HWAAs) were established to manage hazardous and potentially hazardous waste generated during the CAI.

No drums of waste were generated during the investigation of CAS 01-25-01.

Four drums of waste were generated at CAS 03-25-03. One drum contains soil with plutonium-239 contamination and was labeled as "Radioactive Waste - Pending Analysis." One drum contains soil contaminated with TPH-DRO and was labeled as "Hydrocarbon Waste", and one drum contains hydrocarbon contaminated plastic liners. The remaining drum contains plastic sample sleeves, and has been deemed to be sanitary waste.

Nine drums of waste were generated at CAS 03-20-05. Three drums are sanitary, and contain plastic core liners from samples obtained during drilling activities and/or plastic sampling equipment and sample containers. One drum contains hydrocarbon-contaminated plastic sheeting that was placed underneath equipment used on site. Four drums contain sanitary soils removed from drilling activities. One drum contains soils removed from surface locations where plutonium-239 was identified, and they are both labeled "Radioactive Waste - Pending Analysis." 


\section{A.6.1 Characterization}

Analytical results for each drum of waste or associated samples were reviewed to ensure compliance with federal regulations, state regulations, DOE directives/policies, guidance, and waste disposal criteria. Analytical data was reviewed through Tier I, Tier II, and Tier III validation methods.

\section{A.6.2 Waste Streams}

Investigation-derived waste generated during the investigation was segregated into the following waste streams:

- PPE and disposable sampling equipment

- Plastic sheeting and plastic sample sleeves

- Debris including, but not limited to: glass/plastic sample jars, sampling scoops, aluminum foil, and bowls

- Soil and associated debris

\section{A.6.3 Investigation-derived Waste Generated}

A total of thirteen (13) drums of IDW have been generated during the investigation:

- Eight (8) drums were characterized as sanitary waste and recommended for disposal at the NTS-permitted sanitary facilities. These drums were generated at CASs $03-25-03$ and 03-20-05.

- Three (3) drums of IDW were characterized as hydrocarbon waste exceeding the regulatory threshold established by State of Nevada regulations (NDEP, 1997a and $b$ ). The recommended disposal of these drums is at the permitted NTS Hydrocarbon Landfill. The hydrocarbon waste was generated at CASs 03-25-03 and 03-20-05.

- Two (2) drums of soil were characterized as low-level radioactive waste (LLW) and recommended for disposal at the NTS in accordance with the requirements contained in the NTS Waste Acceptance Criteria (NTSWAC) (NNSA/NSO, 2003b). One drum, 322B03 (generated at CAS 03-25-03), is recommended for disposal at the LLW Landfill. Two drums of waste, 322C01 and 322 C09 (generated at CAS 03-20-05), are recommended for shipment to the Area 5 Radioactive Waste Management Site (RWMS). 
Office waste was disposed of throughout the project at the NTS sanitary landfill. Sanitary industrial waste was inspected and disposed of in the NTS industrial waste landfill. Additional waste (e.g., decontamination pad liners) may be generated during completion of waste management activities and closure of HWAAs.

\section{A.6.4 Waste Characterization Samples}

Waste characterization samples were collected from the holding tanks and sumps within the CAS 03-20-05 BOP Shop to facilitate full characterization of the liquids for disposal. A summary of the results of these waste characterization samples is presented in Section A.5.0. Complete results for all samples are maintained in project files. The following sections describe the waste characterization samples collected during the investigation of CAU 322.

\section{A.6.5 Additional Analytical Results Collected For Remediation Waste Characterization}

Several additional samples were collected and/or specific analyses added to samples for the purposes of providing information that can be used to characterize wastes removed from this CAS during potential closure activities. The results from these analyses are compared to disposal criteria and not to PALs.

\section{A.6.5.1 Results for Liquid and Oil Samples}

Liquid and oil samples were collected from the holding tanks, the tank sumps, and the injection well sump so that these materials could be characterized for disposal. Sample results are presented in Table A.6-1.

Table A.6-1

Liquid and Oil Samples Collected at CAS 03-20-05, Injection Well

(Page 1 of 4 )

\begin{tabular}{||c|c|c|c|c||}
\hline Sample Number & Sample Matrix & Parameter & Result & Units \\
\hline \hline 322C054L & Liquid & $\mathrm{H}-3$ & 6,500 & $\mathrm{pCi} / \mathrm{L}$ \\
\hline 322C055L & Liquid & $\mathrm{H}-3$ & 10,000 & $\mathrm{pCi} / \mathrm{L}$ \\
\hline 322C022A & Liquid & Uranium-238 & 0.53 & $\mathrm{pCi} / \mathrm{L}$ \\
\hline 322C022A & Liquid & Uranium-234 & $1.03(\mathrm{M} 3)$ & $\mathrm{pCi} / \mathrm{L}$ \\
\hline
\end{tabular}




\section{Table A.6-1 \\ Liquid and Oil Samples Collected at CAS 03-20-05, Injection Well}

(Page 2 of 4 )

\begin{tabular}{|c|c|c|c|c|}
\hline Sample Number & Sample Matrix & Parameter & Result & Units \\
\hline $322 \mathrm{C} 023 \mathrm{~A}$ & Liquid & Uranium-238 & 0.44 & $\mathrm{pCi} / \mathrm{L}$ \\
\hline $322 \mathrm{C} 023 \mathrm{~A}$ & Liquid & Uranium-234 & 0.63 & $\mathrm{pCi} / \mathrm{L}$ \\
\hline $322 C 039$ & Liquid & Uranium-235 & $0.41(\mathrm{M} 3)$ & $\mathrm{pCi} / \mathrm{L}$ \\
\hline $322 C 039$ & Liquid & Uranium-238 & 5 (M3) & $\mathrm{pCi} / \mathrm{L}$ \\
\hline $322 C 039$ & Liquid & Uranium-234 & $17.8(\mathrm{M} 3)$ & $\mathrm{pCi} / \mathrm{L}$ \\
\hline $322 \mathrm{C} 040$ & Liquid & Uranium-238 & $5.11(\mathrm{M} 3)$ & $\mathrm{pCi} / \mathrm{L}$ \\
\hline $322 \mathrm{C} 040$ & Liquid & Uranium-234 & $15.9(\mathrm{M} 3)$ & $\mathrm{pCi} / \mathrm{L}$ \\
\hline $322 \mathrm{C} 041$ & Liquid & Uranium-234 & 0.41 & $\mathrm{pCi} / \mathrm{L}$ \\
\hline $322 \mathrm{C} 022 \mathrm{~A}$ & Liquid & Gross Beta & 143 (M3) & $\mathrm{pCi} / \mathrm{L}$ \\
\hline $322 \mathrm{C} 023 \mathrm{~A}$ & Liquid & Gross Beta & 191 (M3) & $\mathrm{pCi} / \mathrm{L}$ \\
\hline $322 C 039$ & Liquid & Gross Beta & $54(\mathrm{M} 3)$ & $\mathrm{pCi} / \mathrm{L}$ \\
\hline $322 \mathrm{C} 040$ & Liquid & Gross Beta & $53(\mathrm{M} 3)$ & $\mathrm{pCi} / \mathrm{L}$ \\
\hline $322 \mathrm{C} 041$ & Liquid & Gross Alpha & 5 & $\mathrm{pCi} / \mathrm{L}$ \\
\hline $322 \mathrm{C} 041$ & Liquid & Gross Beta & 18.5 & $\mathrm{pCi} / \mathrm{L}$ \\
\hline $322 \mathrm{C} 054 \mathrm{~L}$ & Liquid & Strontium-90 & 1.19 & $\mathrm{pCi} / \mathrm{L}$ \\
\hline $322 \mathrm{C} 054 \mathrm{~L}$ & Liquid & Gross Beta & 46 & $\mathrm{pCi} / \mathrm{L}$ \\
\hline $322 \mathrm{C} 055 \mathrm{~L}$ & Liquid & Gross Beta & 28.7 & $\mathrm{pCi} / \mathrm{L}$ \\
\hline $322 \mathrm{C} 022 \mathrm{~A}$ & Liquid & Selenium & $0.054(\mathrm{~J}-)$ & $\mathrm{mg} / \mathrm{L}$ \\
\hline $322 \mathrm{C} 022 \mathrm{~A}$ & Liquid & Chromium & 0.34 & $\mathrm{mg} / \mathrm{L}$ \\
\hline $322 \mathrm{C} 022 \mathrm{~A}$ & Liquid & Lead & 0.39 & $\mathrm{mg} / \mathrm{L}$ \\
\hline $322 \mathrm{C} 022 \mathrm{~A}$ & Liquid & Cadmium & 1.8 & $\mathrm{mg} / \mathrm{L}$ \\
\hline $322 \mathrm{C} 023 \mathrm{~A}$ & Liquid & Lead & 0.33 & $\mathrm{mg} / \mathrm{L}$ \\
\hline $322 \mathrm{C} 023 \mathrm{~A}$ & Liquid & Cadmium & 0.87 & $\mathrm{mg} / \mathrm{L}$ \\
\hline $322 C 039$ & Liquid & Lead & $0.037(\mathrm{~J}-)$ & $\mathrm{mg} / \mathrm{L}$ \\
\hline $322 \mathrm{C} 041$ & Liquid & Lead & 0.3 & $\mathrm{mg} / \mathrm{L}$ \\
\hline $322 \mathrm{C} 022 \mathrm{~A}$ & Liquid & Mercury & 0.0074 & $\mathrm{mg} / \mathrm{L}$ \\
\hline $322 \mathrm{C} 023 \mathrm{~A}$ & Liquid & Mercury & 0.0045 & $\mathrm{mg} / \mathrm{L}$ \\
\hline $322 C 039$ & Liquid & Diesel Range Organics & $37(\mathrm{D}, \mathrm{H}, \mathrm{M})$ & $\mathrm{mg} / \mathrm{L}$ \\
\hline $322 \mathrm{C} 040$ & Liquid & Diesel Range Organics & $31(\mathrm{D}, \mathrm{H}, \mathrm{M})$ & $\mathrm{mg} / \mathrm{L}$ \\
\hline $322 \mathrm{C} 054 \mathrm{~L}$ & Liquid & Diesel Range Organics & $26(\mathrm{H}, \mathrm{M}, \mathrm{Z})$ & $\mathrm{mg} / \mathrm{L}$ \\
\hline $322 \mathrm{C} 055 \mathrm{~L}$ & Liquid & Diesel Range Organics & $29(\mathrm{H}, \mathrm{M}, \mathrm{Z})$ & $\mathrm{mg} / \mathrm{L}$ \\
\hline
\end{tabular}




\section{Table A.6-1 \\ Liquid and Oil Samples Collected at CAS 03-20-05, Injection Well}

(Page 3 of 4 )

\begin{tabular}{|c|c|c|c|c|}
\hline Sample Number & Sample Matrix & Parameter & Result & Units \\
\hline $322 \mathrm{C} 023$ & Liquid & Aroclor 1254 & $1(J)^{a}$ & $\mu \mathrm{g} / \mathrm{L}$ \\
\hline $322 C 039$ & Liquid & Aroclor 1254 & $0.98(J)^{b}$ & $\mu \mathrm{g} / \mathrm{L}$ \\
\hline $322 \mathrm{C} 022 \mathrm{~A}$ & Liquid & 2-Butanone & 20 & $\mu \mathrm{g} / \mathrm{L}$ \\
\hline $322 \mathrm{C} 022 \mathrm{~A}$ & Liquid & Acetone & 61 & $\mu \mathrm{g} / \mathrm{L}$ \\
\hline $322 \mathrm{C} 023 \mathrm{~A}$ & Liquid & Acetone & 26 & $\mu \mathrm{g} / \mathrm{L}$ \\
\hline $322 \mathrm{C} 041$ & Liquid & Acetone & 23 & $\mu \mathrm{g} / \mathrm{L}$ \\
\hline 322C054LRR1 & Liquid & Acetone & 1,100 & $\mu \mathrm{g} / \mathrm{L}$ \\
\hline 322C054LRR2 & Liquid & 4-Methyl-2-Pentanone & $32(J)^{c}$ & $\mu \mathrm{g} / \mathrm{L}$ \\
\hline 322C054LRR2 & Liquid & 2-Butanone & $130(J)^{c}$ & $\mu \mathrm{g} / \mathrm{L}$ \\
\hline $322 \mathrm{C} 055 \mathrm{~L}$ & Liquid & 4-Methyl-2-Pentanone & 55 & $\mu \mathrm{g} / \mathrm{L}$ \\
\hline 322C055LRR1 & Liquid & Methylene Chloride & $61(J)^{c}$ & $\mu \mathrm{g} / \mathrm{L}$ \\
\hline 322C055LRR1 & Liquid & 2-Butanone & $85(J)^{c}$ & $\mu \mathrm{g} / \mathrm{L}$ \\
\hline 322C055LRR1 & Liquid & Acetone & $540(\mathrm{~J})^{\mathrm{c}}$ & $\mu \mathrm{g} / \mathrm{L}$ \\
\hline $322 \mathrm{C} 022$ & Liquid & Phenol & 59 & $\mu \mathrm{g} / \mathrm{L}$ \\
\hline $322 \mathrm{C} 022$ & Liquid & 4-Methylphenol & 66 & $\mu \mathrm{g} / \mathrm{L}$ \\
\hline $322 \mathrm{C} 022$ & Liquid & Bis(2-Ethylhexyl)Phthalate & $160(J)^{d}$ & $\mu \mathrm{g} / \mathrm{L}$ \\
\hline $322 C 039$ & Liquid & Bis(2-Ethylhexyl)Phthalate & $25(J)^{d}$ & $\mu \mathrm{g} / \mathrm{L}$ \\
\hline $322 \mathrm{C} 040$ & Liquid & Bis(2-Ethylhexyl)Phthalate & $41(\mathrm{~J})^{\mathrm{d}}$ & $\mu \mathrm{g} / \mathrm{L}$ \\
\hline 322C054LRR1 & Liquid & Phenol & $4,200(J)^{e}$ & $\mu \mathrm{g} / \mathrm{L}$ \\
\hline 322C054LRR1 & Liquid & 4-Methylphenol & $11,000(J)^{f}$ & $\mu \mathrm{g} / \mathrm{L}$ \\
\hline $322 \mathrm{C} 055 \mathrm{~L}$ & Liquid & 4-Methylphenol & $1,300(J)^{f}$ & $\mu \mathrm{g} / \mathrm{L}$ \\
\hline 322C055LRR1 & Liquid & Phenol & $1,500(J)^{e}$ & $\mu \mathrm{g} / \mathrm{L}$ \\
\hline $322 \mathrm{C} 054 \mathrm{O}$ & Oil & Chromium & 9 & $\mathrm{mg} / \mathrm{kg}$ \\
\hline $322 \mathrm{C} 054 \mathrm{O}$ & Oil & Lead & 15 & $\mathrm{mg} / \mathrm{kg}$ \\
\hline $322 \mathrm{C} 054 \mathrm{O}$ & Oil & Cadmium & $17(J)^{g}$ & $\mathrm{mg} / \mathrm{kg}$ \\
\hline $322 \mathrm{C} 055 \mathrm{O}$ & Oil & Lead & 16 & $\mathrm{mg} / \mathrm{kg}$ \\
\hline $322 \mathrm{C} 055 \mathrm{O}$ & Oil & Cadmium & $16(J)^{g}$ & $\mathrm{mg} / \mathrm{kg}$ \\
\hline $322 \mathrm{C} 054 \mathrm{O}$ & Oil & Diesel Range Organics & $880,000(J)^{f}$ & $\mathrm{mg} / \mathrm{kg}$ \\
\hline $322 \mathrm{C} 0550$ & Oil & Diesel Range Organics & $990,000(J)^{f}$ & $\mathrm{mg} / \mathrm{kg}$ \\
\hline $322 \mathrm{C} 054 \mathrm{O}$ & Oil & Methylene Chloride & 340 & $\mu \mathrm{g} / \mathrm{kg}$ \\
\hline
\end{tabular}




\section{Table A.6-1 \\ Liquid and Oil Samples Collected at CAS 03-20-05, Injection Well} (Page 4 of 4 )

\begin{tabular}{||c|c|c|c|c|}
\hline Sample Number & Sample Matrix & Parameter & Result & Units \\
\hline \hline $322 \mathrm{C} 054 \mathrm{O}$ & Oil & Acetone & $350(\mathrm{~J})$ & $\mu \mathrm{g} / \mathrm{kg}$ \\
\hline $322 \mathrm{C} 054 \mathrm{O}$ & Oil & Bis(2-Ethylhexyl)Phthalate & $300,000(\mathrm{~J})^{\mathrm{h}}$ & $\mu \mathrm{g} / \mathrm{kg}$ \\
\hline $322 \mathrm{C} 0550$ & Oil & Bis(2-Ethylhexyl)Phthalate & $210,000(\mathrm{~J})^{\mathrm{h}}$ & $\mu \mathrm{g} / \mathrm{kg}$ \\
\hline
\end{tabular}

${ }^{a} Q u a l i f i e r$ added to laboratory data; record accepted. \%D between columns $>25$.

${ }^{b}$ Qualifier added to laboratory data; record accepted. $\% D$ between columns $>25$. Surrogate recovery $<10$ percent.

${ }^{c}$ Qualifier added to laboratory data; record accepted. Exceeded holding time.

${ }^{\mathrm{d}}$ Qualifier added to laboratory data; record accepted. Matrix effects may exist. Internal area response show extremely low count.

${ }^{e}$ Qualifier added to laboratory data; record accepted. Calibration verification did not meet criteria or was not performed. Surrogates diluted out.

${ }^{f}$ Qualifier added to laboratory data; record accepted. Surrogates diluted out.

${ }^{g}$ Qualifier added to laboratory data; record accepted. Matrix spike recovery outside control limits.

${ }^{\text {h}}$ Qualifier added to laboratory data; record accepted. Matrix effects may exist. Internal standard area count outside control limits

$\mathrm{pCi} / \mathrm{L}=$ Picocuries per liter

$\mathrm{mg} / \mathrm{L}=$ Milligrams per liter

$\mu \mathrm{g} / \mathrm{L}=$ Micrograms per liter

$\mu \mathrm{g} / \mathrm{kg}=$ Micrograms per kilogram

$\mathrm{mg} / \mathrm{kg}=$ Milligrams per kilogram

$\mathrm{D}=\mathrm{A}$ pattern resembling diesel was detected in the sample.

$\mathrm{H}=$ The fuel pattern was in the heavier end of the retention time window for the analyte of interest

$M=A$ pattern resembling motor oil was detected.

$Z=$ The reported result did not resemble the patterns of the following petroleum hydrocarbon products: gasoline, JP-4, JP-8, diesel, mineral spirits, motor oil, Stoddard solvent and bunker $C$.

M3 = The requested minimum detectable concentration was not met, but the reported activity is greater than the reported minimum detectable concentration.

$\mathrm{J}=$ Estimated value

$\mathrm{J}$ - = The result is an estimated quantity, but the result may be biased low. Negative bias found in continuing calibration/method blank.

\section{A.6.5.2 TCLP Metals}

Analytical results for TCLP metals for soil samples collected at CAS 03-20-05 are presented in Table A.6-2. High concentrations of total metals were detected in soils from within the injection well vault and removal of this soil was considered as a potential corrective action. Therefore, in order to provide sufficient data for the characterization of soil within the vault as a waste stream, samples from this location were analyzed for TCLP metals.

Cadmium was the only TCLP metal detected at a concentration above the RCRA toxicity characteristic level (CFR, 2002). Cadmium was detected in the uppermost layer of soil on either side of the well sump. Samples collected at the next lower interval were below the RCRA limit. If soil is 
removed from inside the well vault the first two feet of soil may need to be managed as hazardous waste.

Table A.6-2

Soil Samples for TCLP Metals Detected Above Minimum Reporting Limits at CAS 03-20-05, Injection Well

\begin{tabular}{|c|c|c|c|c|c|}
\hline Borehole & Sample Number & Parameter & Result & RCRA Limit & Units \\
\hline \multirow{6}{*}{$\mathrm{C} 06$} & \multirow{2}{*}{$322 \mathrm{C} 016$} & Lead & 1.3 & $\overline{5}$ & $\overline{\mathrm{mg} / \mathrm{L}}$ \\
\hline & & Cadmium & 2.9 & 1 & $\mathrm{mg} / \mathrm{L}$ \\
\hline & \multirow{2}{*}{$322 \mathrm{C} 017$} & Lead & 0.086 & 5 & $\mathrm{mg} / \mathrm{L}$ \\
\hline & & Cadmium & 0.41 & 1 & $\mathrm{mg} / \mathrm{L}$ \\
\hline & \multirow{2}{*}{$322 \mathrm{C} 018$} & Lead & 0.13 & 5 & $\mathrm{mg} / \mathrm{L}$ \\
\hline & & Cadmium & 0.6 & 1 & $\mathrm{mg} / \mathrm{L}$ \\
\hline \multirow{6}{*}{$\mathrm{C} 07$} & \multirow{2}{*}{$322 \mathrm{C} 019$} & Lead & 0.66 & 5 & $\mathrm{mg} / \mathrm{L}$ \\
\hline & & Cadmium & 1.9 & 1 & $\mathrm{mg} / \mathrm{L}$ \\
\hline & \multirow{2}{*}{$322 \mathrm{C} 020$} & Lead & 0.033 & 5 & $\mathrm{mg} / \mathrm{L}$ \\
\hline & & Cadmium & 0.24 & 1 & $\mathrm{mg} / \mathrm{L}$ \\
\hline & \multirow{2}{*}{$322 \mathrm{C} 021$} & Lead & ND & 5 & $\mathrm{mg} / \mathrm{L}$ \\
\hline & & Cadmium & 0.16 & 1 & $\mathrm{mg} / \mathrm{L}$ \\
\hline
\end{tabular}

a40 CFR 261 "Identification and Listing of Hazardous Waste," (CFR, 2002)

$\mathrm{mg} / \mathrm{L}=$ Milligrams per liter 


\section{A.7.0 Quality Assurance}

This section contains a summary of QA/QC measures implemented during the sampling and analysis activities conducted in support of the CAU 322 corrective action investigation. The following sections discuss the data validation process, QC samples, and nonconformances. A detailed evaluation of the DQIs is presented in Appendix B.

Laboratory analyses were conducted for samples used in the decision-making process to provide a quantitative measurement of any COPCs present. Rigorous QA/QC was implemented for all laboratory samples including documentation, verification and validation of analytical results, and affirmation of DQI requirements related to laboratory analysis. Detailed information regarding the QA program is contained in the Industrial Sites QAPP (NNSA/NV, 2002).

\section{A.7.1 Data Validation}

Data validation was performed in accordance with the Industrial Sites QAPP (NNSA/NV, 2002) and approved protocols and procedures. All laboratory data from samples collected and analyzed for CAU 322 were evaluated for data quality according to the EPA Functional Guidelines (EPA, 1994a and 1999). These guidelines are implemented in a tiered process and are presented in Section A.7.1.1, Section A.7.1.2, and Section A.7.1.3. Data were reviewed to ensure that samples were appropriately processed and analyzed, and the results were evaluated using validation criteria. Documentation of the data qualifications resulting from these reviews is retained in project files as a hard copy and electronic media.

One hundred percent of the data analyzed as part of this investigation were subjected to Tier I and Tier II evaluations. A Tier III evaluation was performed on approximately five percent of the data analyzed.

\section{A.7.1.1 Tier I Evaluation}

Tier I evaluation for chemical and radiochemical analysis examines, but is not limited to:

- Sample count/type consistent with chain of custody

- Analysis count/type consistent with chain of custody 
- Correct sample matrix

- Significant problems stated in cover letter or case narrative

- Completeness of certificates of analysis

- Completeness of Contract Laboratory Program (CLP) or CLP-like packages

- Completeness of signatures, dates, and times on chain of custody

- Condition-upon-receipt variance form included

- Requested analyses performed on all samples

- Date received/analyzed given for each sample

- Correct concentration units indicated

- Electronic data transfer supplied

- Results reported for field and laboratory QC samples

- Whether or not the deliverable met the overall objectives of the project

\section{A.7.1.2 Tier II Evaluation}

Tier II evaluation for chemical and radiochemical analysis examines, but is not limited to:

\section{Chemical:}

- Correct detection limits achieved

- Sample date, preparation date, and analysis date for each sample

- Holding time criteria met

- Quality control batch association for each sample

- Cooler temperature upon receipt

- Sample $\mathrm{pH}$ for aqueous samples, as required

- Detection limits properly adjusted for dilution, as required

- Blank contamination evaluated and applied to sample results/qualifiers

- Matrix spike (MS)/matrix spike duplicate (MSD) percent recoveries $(\% \mathrm{R})$ and relative percent differences (RPDs) evaluated and qualifiers applied to laboratory results, as necessary

- Field duplicate RPDs evaluated using professional judgment and qualifiers applied to laboratory results, as necessary

- Laboratory duplicate RPDs evaluated and qualifiers applied to laboratory results, as necessary

- Surrogate \%R evaluated and qualifiers applied to laboratory results, as necessary

- Laboratory control sample \%R evaluated and qualifiers applied to laboratory results, as necessary

- Initial and continuing calibration evaluated and qualifiers applied to laboratory results, as necessary

- Internal standard evaluation 
- Mass spectrometer tuning criteria

- Organic compound quantitation

- Inductively coupled plasma interference check sample evaluation

- Graphite furnace atomic absorption quality control

- Inductively coupled plasma serial dilution effects

- Recalculation of 10 percent of laboratory results from raw data

\section{Radioanalytical:}

- Correct detection limits achieved

- Blank contamination evaluated and, if significant, qualifiers are applied to sample results

- Certificate of Analysis consistent with data package documentation

- Quality control sample results (duplicates, laboratory control samples, laboratory blanks) evaluated and used to determine laboratory result qualifiers

- Sample results, uncertainty, and minimum detectable concentration evaluated

- Detector system calibrated with National Institute for Standards and Technology (NIST)traceable sources

- Calibration sources preparation was documented, demonstrating proper preparation and appropriateness for sample matrix, emission energies, and concentrations

- Detector system response to daily or weekly background and calibration checks for peak energy, peak centroid, peak full-width half-maximum, and peak efficiency, depending on the detection system

- Tracers NIST-traceable, appropriate for the analysis performed, and recoveries that met QC requirements

- Documentation of all QC sample preparation complete and properly performed

- Spectra lines, photon emissions, particle energies, peak areas, and background peak areas support the identified radionuclide and its concentration

\section{A.7.1.3 Tier III}

The Tier III review is an independent examination of the Tier II evaluation. The Tier III review duplicates the Tier II review for a limited number of samples (typically 5 percent) by an independent agency and includes the following additional evaluations:

\section{Chemical:}

- Recalculation of all laboratory results from raw data 


\section{Radioanalytical:}

- QC sample results (e.g., calibration source concentration, \%R, and RPD) verified

- Radionuclides and their concentration validated as appropriate considering their decay schemes, half-lives, and process knowledge and history of the facility and site

- Each identified line in spectra verified against emission libraries and calibration results

- Independent identification of spectra lines, area under the peaks, and quantification of radionuclide concentration in a random number of sample results

A Tier III review of at least five percent of the sample analytical data was performed by TechLaw, Inc., of Lakewood, Colorado. Tier II and Tier III results were compared and where differences were noted, data were reviewed and changes made accordingly.

\section{A.7.2 Field Quality Control Samples}

There were 31 trip blanks, 6 equipment rinsate blanks, 10 field blanks, 3 source blanks, $11 \mathrm{MS} / \mathrm{MSDs}$, and 12 field duplicates collected and submitted for analysis by laboratory analytical methods as specified in the CAIP. The quality control samples were assigned individual sample numbers and sent to the laboratory "blind." Additional samples were selected by the laboratory to be analyzed as laboratory duplicates.

\section{A.7.2.1 Field Quality Control Samples}

Review of the field blank analytical data for soil sampling indicates that there was no cross-contamination due to transportation practices or the ambient conditions, and that equipment decontamination was adequate. Field, equipment rinsate, and source blanks were analyzed for the applicable parameters listed in Table A.2-2 and trip blanks were analyzed for VOCs only.

During the sampling events, 12 field duplicates were sent as blind samples to the laboratory to be analyzed for the investigation parameters listed in the CAIP. For these samples, the duplicate results precision (i.e., RPDs between the environmental sample results and their corresponding field duplicate sample results) were evaluated to the guidance set forth in the EPA Functional Guidelines (EPA, 1994a). 


\section{A.7.2.2 Laboratory Quality Control Samples}

Analysis of method QC blanks were performed on each sample delivery group (SDG) for inorganics. Analysis for surrogate spikes and preparation blanks (PBs) were performed on each SDG for organics only. Initial and continuing calibration and laboratory control samples (LCSs) were performed for each SDG by Paragon Analytical, Inc. The results of these analyses were used to qualify associated environmental sample results according to the EPA Functional Guidelines (EPA, 1994a and 1999). Documentation of data qualifications resulting from the application of these guidelines is retained in project files as both hard copy and electronic media.

The laboratory included a PB, LCS, and a laboratory duplicate sample with each batch of field samples analyzed for radionuclides.

\section{A.7.3 Field Nonconformances}

There were no field nonconformances identified for the corrective action investigation.

\section{A.7.4 Laboratory Nonconformances}

Laboratory nonconformances are generally due to inconsistencies in the analytical instrumentation operation, sample preparations, extractions, missed holding times, and fluctuations in internal standard and calibration results. Fourteen nonconformances were issued by the laboratory that resulted in qualifying data and have been accounted for during the data qualification process. 


\section{A.8.0 Summary}

Analytes detected in soil samples during the CAI were evaluated against FALs to determine the nature and extent of COCs for CAU 322. Assessment of the data generated from investigation activities indicates the FALs were exceeded in soil samples at all CAU 322 CASs. The following summarizes the results for each CAS.

CAS 01-25-01, AST Berm. Analytical results from all locations within the AST berm indicate that TPH-DRO is present at concentrations above the FAL. The vertical extent of contamination is limited to approximately $12 \mathrm{ft}$ bgs. The lateral extent of contamination was limited to the confines of the berm, as demonstrated by step-out samples.

CAS 03-25-03, AST Berm, Area A. Based on observations made and analytical results of samples collected at CAS 03-25-03 Area A, two locations identified TPH-DRO concentrations above the PALs. The positive result at one of these locations may be due to the presence of oil based paint chips observed on the surface. The source of the paint chips, the paint chips, and the surface soil from this location were removed. Confirmation sampling indicated the contamination was removed. The second location contained TPH-DRO contamination at the 2 to $3 \mathrm{ft}$ bgs interval. Sample collected above and below this interval indicated no contamination. Removal of the upper two feet of the soil, followed by drumming of the 2 to $3 \mathrm{ft}$ interval and confirmation sampling indicated the contamination had been removed. No contamination remains at this site.

CAS 03-25-03 Area B, Mud Plant. Based on observations made and analytical results of samples collected at CAS 03-25-03 Area B, TPH-DRO contamination was identified at various locations and at varying depth throughout the area of interest, However, there was no contiguous TPH-DRO contamination that would allow for the identification of a contaminant plume from any specific source at the site. One sampling location contained plutonium-239 at the surface. The Pu-239 contaminated soil was removed and drummed, and confirmation samples were collected. The confirmation samples indicated that the contamination was removed. It is believed that the surface plutonium-239 contamination arose from surface deposition resulting from atmospheric testing, a common phenomenon in this area of the NTS. 
CAS 03-20-05, Injection Wells. Analytical results indicated several COPCs including TPH, PCBs, lead, and radiological constituents are present at the site above the PAL.

Total petroleum hydrocarbon-DRO contamination was identified at several surface locations on the grounds around the injection well. However, these are bounded laterally by step-out samples and vertically by clean samples beneath the identified contamination, and are believed to be the result of asphalt associated with these sample locations. Soils within the injection well casing showed radiological, metals, and TPH-DRO contamination. The contamination is bounded laterally by samples collected just outside the casing and the metal casing comprising the injection well vault. Vertical extent of contamination was identified by additional samples taken with a drill rig modified to gain access to specific sampling locations.

Plutonium-239 surface contamination was identified at several locations at this CAS, and is believed to be the result of aerial deposition from atmospheric testing. The locations were not contiguous, and not believed to be associated with activities ascribed to the historical use of the site. Removal of these areas of elevated radiological activity was performed as a best management practice to mitigate potential personnel exposure. 


\section{A.9.0 References}

Alderson, S.L., Stoller-Navarro Joint Venture. 2004. Memorandum to R. Boehlecke

(Stoller-Navarro Joint Venture), "CAU 322 Radiological Land Area Surveys," 4 May.

Las Vegas, NV.

BN, see Bechtel Nevada.

Bechtel Nevada. 1995. Nevada Test Site Performance Objective for Certification of Nonradioactive Hazardous Waste, Rev. 0, G-E11/96.01. Las Vegas, NV.

CFR, see Code of Federal Regulations.

Code of Federal Regulations. 2002. Title 40 CFR, "Protection of Environment," Parts 260-282,

"Hazardous Waste Management." Washington, DC: U.S. Government Printing Office.

DOE, see U.S. Department of Energy.

DOE/NV, see U.S. Department of Energy, Nevada Operations Office.

DRI, see Desert Research Institute.

Desert Research Institute. 1985. Additional Intensity Duration Analyses and Design Hyetograph Parameters for Various Parameters for Various Precipitation Stations of the Nevada Test Site, Nevada, August. Prepared by R.H. French. Las Vegas, NV: Water Resources Center.

Desert Research Institute and Carey \& Co., Inc. 1996. Nevada Test Site Historic Building Survey, November. Las Vegas, NV.

EPA, see U.S. Environmental Protection Agency.

FFACO, see Federal Facility Agreement and Consent Order.

Federal Facility Agreement and Consent Order. 1996 (as amended). Agreed to by the State of Nevada, the U.S. Department of Energy, and the U.S. Department of Defense.

Moore, J., Science Applications International Corporation. 1999. Memorandum to M. Todd (SAIC), "Background Concentrations for NTS and TTR Soil Samples," 3 February. Las Vegas, NV.

NAC, see Nevada Administrative Code.

NBMG, see Nevada Bureau of Mines and Geology.

NCRP, see National Council on Radiation Protection and Measurements. 
NDEP, see Nevada Division of Environmental Protection.

NNSA/NV, see U.S. Department of Energy, National Nuclear Security Administration Nevada Operations Office.

NNSA/NSO, see U.S. Department of Energy, National Nuclear Security Administration Nevada Site Office.

National Council on Radiation Protection and Measurements. 1999. Recommended Screening Limits for Contaminated Surface Soil and Review of Factors Relevant to Site-Specific Studies, Report No. 129. Bethesda, MD.

Nevada Administrative Code. 2002. NAC 445A.2272, "Contamination of Soil: Establishment of Action Levels." Carson City, NV.

Nevada Bureau of Mines and Geology. 1998. Mineral and Energy Resource Assessment of the Nellis Air Force Range, Open-File Report 98-1. Reno, NV.

Nevada Division of Environmental Protection. 1997a (as amended). Class III Solid Waste Disposal Site for Hydrocarbon Burdened Soils, Area 6 of the NTS, Permit SW 13097 02. Reno, NV.

Nevada Division of Environmental Protection. 1997b (as amended). Class III Solid Waste Disposal Site; U10C, Area 9 of the NTS, Permit SW 1309703. Carson City, NV.

Stoller-Navarro Joint Venture. 2003. Site-Specific Health and Safety Plan for CAU 322, Areas 1 and 3, Release Sites and Injection Wells, Nevada Test Site, Nevada. Las Vegas, NV.

U.S. Department of Energy. 1993. DOE Order 5400.5 Change 2, "Radiation Protection of the Public and the Environment." Washington, DC.

U.S. Department of Energy, Nevada Operations Office. 2000. NV/YMP Radiological Control Manual, Rev. 4, DOE/NV/11718-079. Prepared by A.L. Gile of Bechtel Nevada. Las Vegas, NV.

U.S. Department of Energy, National Nuclear Security Administration Nevada Operations Office. 2002. Industrial Sites Quality Assurance Project Plan, Nevada Test Site, Nevada, Rev. 3, DOE/NV--372. Las Vegas, NV.

U.S. Department of Energy, National Nuclear Security Administration Nevada Site Office. 2003a. Corrective Action Investigation Plan for Corrective Action Unit 322: Areas 1 and 3, Release Sites and Injection Wells, Nevada Test Site, Nevada, DOE/NV--893, Rev. 0. Las Vegas, NV.

U.S. Department of Energy, National Nuclear Security Administration Nevada Site Office. $2003 \mathrm{~b}$. Nevada Waste Acceptance Criteria, Rev. 5, DOE/NV--325. Las Vegas, NV. 
U.S. Environmental Protection Agency. 1994a. Contract Laboratory Program National Functional Guidelines for Inorganic Data Review, EPA/540/R-94/013. Washington, DC.

U.S. Environmental Protection Agency. 1994b. Guidance for the Data Quality Objectives Process, EPA QA/G-4. Washington, DC.

U.S. Environmental Protection Agency. 1996. Test Methods for Evaluating Solid Waste, Physical/Chemical Methods, SW-846, 3rd Edition, CD-ROM PB97-501928GEI. Washington, DC.

U.S. Environmental Protection Agency. 1999. Contract Laboratory Program National Functional Guidelines for Organic Data Review, EPA 540/R-99/008. Washington, DC.

U.S. Environmental Protection Agency. 2002. Region IX Preliminary Remediation Goals (PRGs). Available at www.epa.gov/region09/waste/sfund/prg. San Francisco, CA. 
Appendix B

Data Assessment 


\section{B.1.0 Data Assessment}

This appendix provides an assessment of the CAU 322 investigation results to determine whether the data collected met the DQOs and can support their intended use in the decision-making process. This assessment includes a reconciliation of the data with the general CSMs established for this project.

The following sections provide an evaluation of the DQIs in determining the degree of acceptability or usability of the reported data for the decision-making process.

\section{B.1.1 Precision}

Precision is a measure of agreement among a replicate set of measurements of the same property under similar conditions. This agreement is expressed as the RPD between duplicate measurements (EPA, 1996).

For the purpose of determining data precision of sample analyses, all water and soil samples, including field QC samples (e.g., trip blanks, equipment rinsate samples, field blanks) were evaluated and incorporated into the precision calculation.

The RPD is determined by dividing the difference between the replicate measurement values by the average measurement value and multiplying the result by 100 , or:

$$
\operatorname{RPD}=\left|100 \times\left[\left\{\left(a_{1}-a_{2}\right) /\left(a_{1}+a_{2}\right) / 2\right\}\right]\right|
$$

Where:

$\mathrm{a}_{1}=$ The sample value

$\mathrm{a}_{2}=$ The duplicate sample value

Determinations of precision can be made for field samples, laboratory duplicates (LD), or both. For field samples, duplicates are collected simultaneously with a sample from the same source under similar conditions in separate containers. The duplicate sample is treated independently of the original sample in order to assess field impacts and laboratory performance on precision through a comparison of results. Laboratory precision is evaluated as part of the required QC program to assess performance of analytical procedures. The laboratory sample duplicates are an aliquot or subset of a 
field sample generated in the laboratory. They are not a separate sample but portions of an existing sample. Typically, other laboratory duplicate QC samples include MSD and laboratory control sample duplicate (LCSD).

The variability in the results from the analysis of field duplicates is generally greater than the variability in the results of laboratory duplicates. This higher variability for field duplicates results from the increased potential to introduce factors influencing the analytical results during sampling, sample preparation, containerization, handling, packaging, preservation, and environmental conditions before the samples reach the laboratory. Laboratory QC samples only assess the variability of results introduced by sample handling and preparation in the laboratory and by the analytical procedure, which also impacts field duplicates. In addition, the variability in duplicate results is expected to be greater for soil samples than water samples, primarily due to the inherent heterogeneous nature of soil samples, despite sample preparation methods that include mixing to improve sample homogeneity.

\section{B.1.1.1 Precision for Chemical Analysis}

The RPD criteria used for assessment of laboratory sample duplicate precision for analytical results of samples collected at CAU 322 were established as follows:

- Inorganic analysis RPD criteria is obtained from the EPA's Contract Laboratory Functional Guidelines for Inorganic Data Review (EPA, 1994).

- Organic analysis RPD criteria is established by the laboratory to evaluate precision for MSD and LCSD analyses.

The control limits are evaluated at the laboratory on a quarterly basis by monitoring the historical data and performance for each method. No review criteria for organic field duplicate RPD comparability have been established by EPA; therefore, the laboratory MS/MSD RPD criteria is applied for precision evaluation of field duplicates.

Precision values for organic and inorganic analysis that are within the established control criteria indicate that analytical results for associated samples are valid. Laboratory duplicate RPD values that are outside the criteria for organic analysis do not necessarily result in the qualification of analytical data. It is only one factor in making an overall judgment about the quality of the reported analytical 
results. Inorganic laboratory duplicate RPD values outside the established control criteria do result in the qualification of associated analytical results as estimated. Field duplicate RPD values that are outside the criteria for organic and inorganic analyses do not result in the qualification of analytical data. Out of control RPD values do not necessarily indicate that the data is not useful for the purpose intended; however, it is an indication data precision should be considered for the overall assessment of the data quality and potential impact on data application in meeting project site characterization objectives. Method-specific precision as RPD is determined by taking the number of measurements within criteria, dividing that by the number of measurements analyzed, and multiplying by 100 .

For the purpose of determining data precision of sample analyses for CAU 322, all soil and water samples, including field QC samples (e.g., trip blanks, equipment rinsate samples, field blanks) were evaluated and incorporated into the precision calculation.

Precision for the measurement of target compounds or analytes collected at CAU 322 was determined for total RCRA metals plus beryllium, SVOCs, VOCs, PCBs, TPH-DRO, and TPH-GRO. Table B.1-1 provides the chemical precision analysis results.

Inorganic laboratory duplicate RPD values outside the established control criteria result in estimation for that measurement of all associated samples in the SDG. For example, if a laboratory duplicate had a RPD value for lead outside the established control criteria, lead results for all of the samples in that SDG would be qualified as estimated.

Out of control RPD values do not necessarily indicate that the data is not useful for the purpose intended. It does indicate that precision should be considered in the overall assessment of the data quality and impact to the application of associated data to meeting the project's objectives.

\section{B.1.1.2 Precision for Radiochemical Analysis}

The precision of radiochemical measurements is evaluated by measuring two aliquots of a sample and comparing the results. A laboratory duplicate is measured with every batch of samples analyzed by the laboratory. Field duplicate data is available when two aliquots of a sample are submitted to the laboratory for analysis. Matrix spike duplicates, also used to evaluate precision, are performed by the laboratory upon request. 
Table B.1-1

Chemical Precision Measurements for CAU 322

\begin{tabular}{|c|c|c|c|c|c|c|c|}
\hline & \multicolumn{5}{|c|}{ ORGANICS } & \multicolumn{2}{|c|}{ INORGANICS } \\
\hline & VOCs & SVOCs & $\begin{array}{l}\text { TPH- } \\
\text { DRO }\end{array}$ & $\begin{array}{l}\text { TPH- } \\
\text { GRO }\end{array}$ & PCBs & Metals* & Mercury \\
\hline \multicolumn{8}{|c|}{ Matrix Spike Duplicate (MSD) Precision } \\
\hline Total Number of MSD Measurements & 85 & 176 & 16 & 15 & 30 & 103 & 13 \\
\hline Total Number of RPDs Within Criteria & 85 & 175 & 16 & 15 & 30 & 102 & 13 \\
\hline MSD Percent Precision & 100 & 99.4 & 100 & 100 & 100 & 99 & 100 \\
\hline \multicolumn{8}{|c|}{ Laboratory Control Sample Duplicate (LCSD) Precision } \\
\hline Total Number of LCSD Measurements & 100 & 253 & 23 & 20 & 46 & 173 & 17 \\
\hline Total Number of RPDs Within Criteria & 100 & 253 & 23 & 20 & 46 & 173 & 17 \\
\hline LCSD Percent Precision & 100 & 100 & 100 & 100 & 100 & 100 & 100 \\
\hline \multicolumn{8}{|c|}{ Field Sample Duplicate (FD) Precision } \\
\hline Total Number of FD Measurements & 621 & 639 & 9 & 9 & 63 & 72 & 9 \\
\hline Total Number of RPDs Within Criteria & 614 & 638 & 8 & 8 & 62 & 67 & 8 \\
\hline FD Percent Precision & 98.9 & 99.8 & 88.9 & 88.9 & 98.4 & 93.1 & 88.9 \\
\hline \multicolumn{8}{|c|}{ Laboratory Sample Duplicate (Lab-Dup) Precision } \\
\hline Total Number of Lab-Dup Measurements & NA & NA & NA & NA & NA & 103 & 13 \\
\hline Total Number of RPDs Within Criteria & NA & NA & NA & NA & NA & 103 & 13 \\
\hline Lab-Dup Percent Precision & NA & NA & NA & NA & NA & 100 & 100 \\
\hline
\end{tabular}

*Measurements include arsenic, barium, beryllium, cadmium, chromium, lead, selenium, silver

NA $=$ Not applicable 
The duplicate precision is evaluated using the RPD or normalized difference. The RPD is applicable when both the sample and its duplicate have concentrations of the target radionuclide exceeding five times their minimum detectable concentration. This excludes many measurements because the samples contain nondetectable or low levels of the target radionuclide. In situations where the RPD does not apply, duplicate results are evaluated using the normalized difference (ND) which is expressed by:

$$
\text { Normalized Difference }=\frac{\mathrm{S}-\mathrm{D}}{\sqrt{\left(\mathrm{TPU}_{\mathrm{S}}\right)^{2}+\left(\mathrm{TPU}_{\mathrm{D}}\right)^{2}}}
$$

Where:

$$
\begin{array}{ll}
\mathrm{S} & =\text { Sample result } \\
\mathrm{D} & =\text { Duplicate Result } \\
\mathrm{TPU}_{\mathrm{S}} & =2 \mathrm{~F} \text { total propagated uncertainty of the sample } \\
\mathrm{TPU}_{\mathrm{D}} & =2 \mathrm{~F} \text { total propagated uncertainty of the duplicate } \\
\mathrm{F} & =\text { Standard deviation }
\end{array}
$$

The control limit for the normalized difference is a unitless value from -1.96 to 1.96, which represent a confidence level of 95 percent. Depending on the sample concentration, only one duplicate evaluation needs to be performed. If the sample duplicate RPD or normalized difference is outside the control limit, the field samples measured in the same analytical batch will be qualified. Samples are not qualified based on field duplicates or MSDs.

A duplicate comparison that is outside control limits does not necessarily indicate that the data is not useful for the purpose intended; however, it is an indication that data precision should be considered for the overall assessment of the data quality and potential impact on data application in meeting project site characterization objectives.

Table B.1-2 provides the radiological precision analysis results. The low field duplicate precision, 33 percent RPD, for plutonium is due to the nonhomogeneous plutonium contamination of the soil samples. 
Table B.1-2

Radiological Precision Measurements for CAU 322

\begin{tabular}{|c|c|c|c|c|c|c|c|}
\hline & $\begin{array}{c}\text { Gamma } \\
\text { Spectroscopy }\end{array}$ & $\begin{array}{l}\text { Isotopic } \\
\text { Uranium }\end{array}$ & $\begin{array}{l}\text { Isotopic } \\
\text { Plutonium }\end{array}$ & Strontium-90 & $\begin{array}{l}\text { Gross } \\
\text { Alpha }\end{array}$ & $\begin{array}{c}\text { Gross } \\
\text { Beta }\end{array}$ & Tritium \\
\hline \multicolumn{8}{|c|}{ Matrix Spike Duplicate (MSD) Precision } \\
\hline $\begin{array}{l}\text { Total Number of MSD } \\
\text { Measurements }\end{array}$ & 0 & 0 & 0 & 0 & 5 & 5 & 0 \\
\hline $\begin{array}{l}\text { Total Number of RPDs } \\
\text { Within Criteria }\end{array}$ & 0 & 0 & 0 & 0 & 5 & 5 & 0 \\
\hline $\begin{array}{l}\text { MSD Percent } \\
\text { Precision }\end{array}$ & NA & NA & NA & NA & 100 & 100 & NA \\
\hline \multicolumn{8}{|c|}{ Laboratory Sample Duplicate (Lab-Dup) Precision (as RPD) } \\
\hline $\begin{array}{l}\text { Total Number of } \\
\text { Measurements }\end{array}$ & 24 & 34 & 18 & 4 & 7 & 4 & 0 \\
\hline $\begin{array}{l}\text { Total Number of RPDs } \\
\text { Within Criteria }\end{array}$ & 24 & 34 & 16 & 4 & 6 & 4 & 0 \\
\hline Percent Precision & 100 & 100 & 89 & 100 & 86 & 100 & NA \\
\hline \multicolumn{8}{|c|}{ Normalized Difference } \\
\hline $\begin{array}{l}\text { Total Number of } \\
\text { Measurements }\end{array}$ & 438 & 26 & 30 & 13 & 5 & 8 & 10 \\
\hline $\begin{array}{l}\text { Total Number of NDs } \\
\text { Within Criteria }\end{array}$ & 436 & 26 & 30 & 13 & 5 & 8 & 10 \\
\hline Percent Precision & 99.5 & 100 & 100 & 100 & 100 & 100 & 100 \\
\hline \multicolumn{8}{|c|}{ Field Sample Duplicate (FD) Precision (as RPD) } \\
\hline $\begin{array}{l}\text { Total Number of } \\
\text { Measurements }\end{array}$ & 8 & 10 & 3 & 0 & 2 & 0 & 0 \\
\hline $\begin{array}{l}\text { Total Number of RPDs } \\
\text { Within Criteria }\end{array}$ & 8 & 10 & 1 & 0 & 1 & 0 & 0 \\
\hline Percent Precision & 100 & 100 & 33 & NA & 50 & NA & NA \\
\hline \multicolumn{8}{|c|}{ Normalized Difference } \\
\hline $\begin{array}{l}\text { Total Number of } \\
\text { Measurements }\end{array}$ & 102 & 5 & 9 & 5 & 1 & 3 & 3 \\
\hline $\begin{array}{l}\text { Total Number of NDs } \\
\text { Within Criteria }\end{array}$ & 102 & 5 & 7 & 5 & 1 & 3 & 3 \\
\hline Percent Precision & 100 & 100 & 78 & 100 & 100 & 100 & 100 \\
\hline
\end{tabular}

$\mathrm{NA}=$ Not applicable 
For the purpose of determining data precision of sample analyses for CAU 322, all liquid and soil duplicates were evaluated and incorporated into Table B.1-2.

The isotopic gamma analysis provides results for 22 radionuclides. Only two or three of these radionuclides are usually present in sufficient concentration to allow the determination of their RPDs. The duplicate data for the remaining radionuclides is compared using the normalized difference. Matrix spike duplicate samples were not analyzed by the laboratory because of the difficulty in preparing homogeneous spiked duplicates and the radioactive waste produced. The results of the precision tests for laboratory isotopic gamma measurements are included in Table B.1-2.

Thirty duplicate pairs were measured with each containing 22 radionuclides. One-hundred percent of the RPD and 99 percent of the normalized difference comparisons were acceptable.

The isotopic uranium analysis includes the measurement of three radionuclides, two of which often occur in concentrations sufficient for RPD evaluation. As shown by the laboratory uranium precision results in Table B.1-2, 100 percent of both the RPD tests and the normalized difference tests were within limits.

The isotopic plutonium analysis measures two radionuclides, but usually their concentrations in samples are too low to permit the evaluation of the RPD. Table B.1-2 contains the precision results for the laboratory duplicates measured with the plutonium laboratory batches.

The strontium-90 laboratory duplicate analyses are listed in Table B.1-2. One-hundred percent of the RPD and normalized difference tests were within control limits.

The were no MS and MSD analyses conducted for radiological measurements in CAU 322.

The results of the comparison of the field duplicates are provided in Table B.1-2. Two isotopic plutonium RPDs and one gross alpha RPD were outside the control limits. The duplicates are taken from locations adjacent to the original sample. Of the 151 precision tests performed for field duplicate samples, 146 or 97 percent were acceptable. 


\section{B.1.1.3 Precision Summary}

Overall, the precision for CAU 322 measurements were within DQI specifications. The results of the duplicate comparison of the field and laboratory duplicates for chemical analyses are provided in Table B.1-1. Of the 1,422 precision tests performed on FDs, 1,405 or 98.8 percent were within control limits. Of the 1,011 precision tests for LDs, LCSD, and MSDs, 1,009 or 99.8 percent were within control limits. More importantly, individual precision summaries for the designated analyses, as shown in the individual tables, were also within control limits.

The results of LDs for radiochemical analyses are provided in Table B.1-2. Of the 563 precision tests performed for LDs, 558 or 99.1 percent were within control limits. The results of the duplicate comparison of the FDs for radiochemical analyses are provided in Table B.1-2. Of the 151 precision tests performed on the FDs, 146 or 96.7 percent were within the control limits.

In summary, precision for CAU 322 should be considered to be within acceptable limits for evaluation of the resulting data, thereby achieving established DQOs.

\section{B.1.2 Accuracy}

Accuracy is a measure of the closeness of an individual measurement or the average of a number of measurements to the true value. Accuracy includes a combination of random error (precision) and systematic error (bias) components that result from sampling and analytical operations. This closeness is expressed as \% $\mathrm{R}$ (EPA, 1996).

For the purpose of determining data precision of sample analyses, all water and soil samples, including field QC samples (e.g., trip blanks, equipment rinsate samples, field blanks) were evaluated and incorporated into the precision calculation.

\section{B.1.2.1 Accuracy for Chemical Analysis}

Table B.1-3 provides the chemical accuracy analysis results.

The MS percent accuracy for DROs is 60.0 percent. Only one sample (322C022) was qualified as estimated due to matrix spike recoveries exceeding criteria for DROs. All other sample results were not affected by matrix spike recoveries. 
Table B.1-3

Chemical Accuracy Measurements for CAU 322

\begin{tabular}{|c|c|c|c|c|c|c|c|}
\hline & \multicolumn{5}{|c|}{ ORGANICS } & \multicolumn{2}{|c|}{ INORGANICS } \\
\hline & VOCs & svocs & $\begin{array}{l}\text { TPH- } \\
\text { DRO }\end{array}$ & $\begin{array}{l}\text { TPH- } \\
\text { GRO }\end{array}$ & PCBs & Metals* & Mercury \\
\hline \multicolumn{8}{|c|}{ Matrix Spike (MS) Accuracy } \\
\hline $\begin{array}{l}\text { Total Number of MS } \\
\text { Measurements }\end{array}$ & 170 & 352 & 30 & 32 & 60 & 206 & 26 \\
\hline $\begin{array}{l}\text { Total Number of MS } \\
\text { Measurements Within Criteria }\end{array}$ & 139 & 337 & 18 & 29 & 54 & 199 & 25 \\
\hline MS Percent Accuracy & 81 & 95.7 & 60.0 & 90.6 & 90.0 & 96.6 & 96.2 \\
\hline \multicolumn{8}{|c|}{ Laboratory Control Sample (LCS) Accuracy } \\
\hline $\begin{array}{l}\text { Total Number of LCS } \\
\text { Measurements }\end{array}$ & 200 & 517 & 46 & 40 & 92 & 346 & 34 \\
\hline $\begin{array}{l}\text { Total Number of LCS } \\
\text { Measurements Within Criteria }\end{array}$ & 200 & 509 & 46 & 40 & 92 & 346 & 34 \\
\hline LCS Percent Accuracy & 100 & 98.5 & 100 & 100 & 100 & 100 & 100 \\
\hline \multicolumn{8}{|c|}{ Surrogate Accuracy } \\
\hline $\begin{array}{l}\text { Total Number of Measurements } \\
\text { Analyzed }\end{array}$ & 13,593 & 12,567 & 171 & 163 & 1,197 & NA & NA \\
\hline $\begin{array}{l}\text { Total Number of Measurements } \\
\text { Not Affected by Out-of-Control } \\
\text { Surrogates }\end{array}$ & 13,589 & 12,283 & 160 & 163 & 952 & NA & NA \\
\hline Surrogate Percent Accuracy & 100 & 97.7 & 93.6 & 100 & 79.5 & NA & NA \\
\hline
\end{tabular}

*Measurements include arsenic, barium, beryllium, cadmium, chromium, lead, selenium, silver NA = Not applicable

Accuracy is determined by analyzing a reference material of known pollutant concentration or by reanalyzing a sample to which a material of known concentration or amount of pollutant has been added (spiked). Accuracy is expressed as percent recovery for the purposes of evaluating the quality of data reported for CAU 322.

Matrix spike samples are prepared by adding a known concentration of a target analyte to a specified amount of matrix sample for which an independent estimate of the target analyte concentration is available. Spiked samples are used to determine the laboratory's overall efficiency by comparing the percent recovered to the known true value. For example, a sample that is spiked with $10 \mathrm{ppm}$ of a 
known analyte should produce a reported result of $10 \mathrm{ppm}$ greater than the value of the sample itself. Consequently, the accuracy for this analysis would be reported as 100 percent. Matrix spike recoveries within the specified criteria for organic and inorganic analyses indicate the laboratory is operating within established controls and producing valid, quality results. Matrix spike results outside the control limits for organic analyses may not result in qualification of the data. An assessment of the entire analytical process is performed to determine the quality of the data and whether qualification is necessary.

Laboratory control samples are generated to provide accuracy of analytical methods and laboratory performance. They are prepared, extracted (as required by method), analyzed, and reported once per SDG per matrix. For organic analyses, laboratory control limits are used to evaluate the accuracy of all analyses. The control limits are evaluated at the laboratory quarterly by monitoring the historical data and performance for each method. The acceptable limits for inorganic analyses are established in the EPA Contract Laboratory Functional Guidelines for Inorganic Data Review (1994). Sample results within established control ranges for organic and inorganic analyses show that the analytical method is accurate and the data provided are valid.

Surrogates (system monitoring compounds) are used to assess the method performance for each sample analyzed for organic analyses. Control limits established by the laboratory are used to evaluate the accuracy of the surrogate recoveries. Factors beyond the laboratory's control, such as sample matrix effects, can cause the measured values to be outside of the established criteria. Therefore, the entire sampling and analytical process must be evaluated when determining the quality of the analytical data provided.

Table B.1-3 identifies the number of matrix spike, laboratory control, and surrogate measurements performed for CAU 322. The table presents the total number of measurements analyzed, the number of measurements within the specified criteria, and the percent-accuracy of each method. Methodspecific accuracy is determined by taking the number of measurements within criteria, dividing that by the total number of measurements analyzed, and multiplying by 100 . For organic analyses, each sample had surrogates analyzed; therefore, the number of surrogates is significantly greater than the number of matrix spike and laboratory control samples. 
The matrix spike accuracy results for organic analyses in Table B.1-3 include the total number of matrix spike measurements per analysis and the number of matrix spike measurements within criteria. All samples for organic analyses within the associated SDG are not qualified, only the native sample in which the spike was added. Inorganic matrix spike results outside of the established control criteria do result in data qualified as estimated for all the samples in that batch. However, only the analyte(s) outside of control requires qualification.

Table B.1-3 includes the total number of LCS measurements per analysis and the number of LCS measurements within criteria. Laboratory control samples within the specified criteria for organic and inorganic analyses indicate the laboratory is producing valid data. Laboratory control samples outside of the established criteria result in the qualification of inorganic data and may result in the qualification of organic data. For organic analyses, an evaluation of the overall analytical process is performed to determine if data qualification is necessary. Inorganic LCS recoveries outside of established controls require data to be qualified for the individual analyte out of control. If the LCS criteria are not met, the laboratory performance and method accuracy are in question.

Surrogates reported within established control criteria indicate good laboratory method performance and the absence of matrix influences on the samples and result in quality, valid data. Table B.1-3 includes the total number of sample measurements performed for each method and the total number of sample measurements qualified for surrogate recoveries exceeding criteria. The estimated organic data in this CAU do not necessarily indicate the data is not useful. Data qualification is one factor to be considered in the overall assessment of the data quality and the impact to the project's objectives.

Accuracy for the measurement of target analytes collected at CAU 322 was determined for total RCRA metals plus beryllium, TCLP metals, SVOCs, VOCs, PCBs, TPH-DRO, and TPH-GRO.

For the purpose of determining data accuracy of sample analysis for CAU 322, all soil and water samples including field QC samples (e.g., trip blanks, equipment rinsate samples, field blanks) were evaluated and incorporated into the accuracy calculation.

\section{B.1.2.2 Accuracy for Radiochemical Analysis}

Table B.1-4 provides the radiological accuracy analysis results. 
Table B.1-4

Radiological Accuracy Measurements for CAU 322

\begin{tabular}{|c|c|c|c|c|c|c|c|}
\hline & $\begin{array}{c}\text { Gamma } \\
\text { Spectroscopy }\end{array}$ & $\begin{array}{l}\text { Isotopic } \\
\text { Uranium }\end{array}$ & $\begin{array}{l}\text { Isotopic } \\
\text { Plutonium }\end{array}$ & Strontium-90 & $\begin{array}{l}\text { Gross } \\
\text { Alpha }\end{array}$ & $\begin{array}{l}\text { Gross } \\
\text { Beta }\end{array}$ & Tritium \\
\hline \multicolumn{8}{|c|}{ Matrix Spike (MS) Accuracy } \\
\hline $\begin{array}{l}\text { Total Number of MS } \\
\text { Measurements }\end{array}$ & 0 & 0 & 0 & 0 & 10 & 10 & 3 \\
\hline $\begin{array}{l}\text { Total Number of MS } \\
\text { Measurements } \\
\text { Within Criteria }\end{array}$ & 0 & 0 & 0 & 0 & 6 & 10 & 3 \\
\hline $\begin{array}{l}\text { MS Percent } \\
\text { Accuracy }\end{array}$ & NA & NA & NA & NA & 60 & 100 & 100 \\
\hline \multicolumn{8}{|c|}{ Laboratory Control Sample (LCS) Accuracy } \\
\hline $\begin{array}{l}\text { Total Number of } \\
\text { Measurements }\end{array}$ & 69 & 42 & 27 & 18 & 10 & 10 & 8 \\
\hline $\begin{array}{l}\text { Total Number of } \% \\
\text { RECs Within Criteria }\end{array}$ & 69 & 42 & 27 & 16 & 10 & 10 & 8 \\
\hline Percent Accuracy & 100 & 100 & 100 & 88 & 100 & 100 & 100 \\
\hline
\end{tabular}

Laboratory control samples and MS samples are used to determine the accuracy of radioanalytical measurements. The LCS is prepared by adding a known concentration of the radionuclide being measured to a sample that does not contain radioactivity (i.e., distilled water). This sample is analyzed with the field samples using the same sample preparation, reagents, and analytical methods employed for the samples. One LCS is prepared with each batch of samples for analysis by a specific measurement.

Matrix spike samples are prepared by adding a known concentration of a target radionuclide to a specified field sample with a measured concentration. The MS samples are analyzed to determine if the measurement accuracy is affected by the sample matrix. The MS samples are analyzed with sample batches when requested. For CAU 322, MS samples were performed for the tritium, gross alpha and gross beta analyses. Normally, a MS analysis is not performed for gamma measurements since this is a nondestructive analysis using large sample aliquots. This results in radioactive waste and it is difficult to prepare homogeneous solid spike samples. 
The accuracy of the LCS determination is expressed as a percent recovery by the following:

$$
\% R=\frac{\text { Amount of Analyte Measured }}{\text { Amount of Analyte Added }} \times 100
$$

The accuracy of the MS determination is expressed as a percent recovery by the following:

$$
\% R=\frac{\text { MS Result }- \text { Sample Result }}{\text { Amount of Analyte Added }} \times 100
$$

If the LCS recoveries are outside acceptable control limits, qualifiers will be added to the field samples analyzed with the LCS. However, MS results outside this control range may not result in qualification of the data. An assessment of the entire analytical process including the sample matrix is performed to determine if qualification is necessary.

Table B.1-4 identifies the number of LCS samples, including soil and water matrices, measured for each radiochemical measurement for CAU 322. The percent accuracy for the procedure is determined as the number of LCS samples analyzed within the control limits, divided by the total number analyzed, and multiplied by 100. MS analyses were not conducted as part of this CAU for radiological parameters.

Each isotopic gamma LCS sample contains four radionuclides, each of which has a percent recovery determined. As indicated in Table B.1-4, 100 percent of the gamma LCS measurements were within control limits.

Three uranium radionuclides are added to the isotopic uranium LCS samples, but the uranium-235 concentration is usually too low to allow evaluation. The isotopic plutonium, strontium-90, and gross beta LCS samples contain one added radionuclide.

Laboratory control samples within the specified criteria for radiological analyses indicate the laboratory is producing valid data. If the LCS criteria are not met, the laboratory performance and method accuracy are in question. Radiological LCS recoveries outside of established controls require 
data to be qualified for the individual radionuclide out of control. Since LCS recoveries were 100 percent for all analyses, no field samples were qualified based on LCS performance.

\section{B.1.2.3 Accuracy Summary}

Overall accuracy for CAU 322 was within acceptable limits. Surrogate recoveries, which gauge the accuracy of individual sample results for specified chemical analyses, were within acceptable accuracy ranges ( 80 percent or better). Acceptable MS recovery results were 81 percent or better for chemical and radiochemical analyses. The percentage of acceptable LCS recoveries was at least 98 percent for all chemical analyses, and at least 88 percent for radioanalytical LCS recoveries.

In summary, accuracy results for CAU 322 should be considered acceptable and meet DQO requirements.

\section{B.1.3 Completeness}

Completeness is defined as the acquisition of sufficient data of the appropriate quality to satisfy DQO decision data requirements. Table B.1-5 and Table B.1-6 provide the chemical and radiological completeness analysis results, respectively.

Table B.1-5

Chemical Completeness Measurements for CAU 322

\begin{tabular}{|c|c|c|c|c|c|c|c|}
\hline \multirow[b]{2}{*}{ Completeness Parameters } & \multicolumn{5}{|c|}{ ORGANICS } & \multicolumn{2}{|c|}{ INORGANICS } \\
\hline & VOCs & SVOCs & $\begin{array}{l}\text { TPH- } \\
\text { DRO }\end{array}$ & $\begin{array}{l}\text { TPH- } \\
\text { GRO }\end{array}$ & PCBs & Metals* & Mercury \\
\hline \multicolumn{8}{|c|}{ Sample Analysis Completeness } \\
\hline Total Samples Sent to Laboratory & 194 & 171 & 171 & 163 & 171 & 171 & 171 \\
\hline Total Samples Analyzed & 194 & 171 & 171 & 163 & 171 & 171 & 171 \\
\hline $\begin{array}{l}\text { Total Samples Not Analyzed by the } \\
\text { Laboratory }\end{array}$ & 0 & 0 & 0 & 0 & 0 & 0 & 0 \\
\hline Percent Completeness & 100 & 100 & 100 & 100 & 100 & 100 & 100 \\
\hline \multicolumn{8}{|c|}{ Measurement Usability Completeness } \\
\hline Total Measurements ** & 13,593 & 12,567 & 171 & 163 & 1,197 & 1,360 & 171 \\
\hline Total Measurements Rejected - Field & 0 & 0 & 0 & 0 & 0 & 0 & 0 \\
\hline Total Measurements Rejected - Lab/Matrix & 19 & 341 & 0 & 0 & 26 & 0 & 0 \\
\hline Percent Completeness & 99.9 & 97.3 & 100 & 100 & 97.8 & 100 & 100 \\
\hline
\end{tabular}

${ }^{*}$ Measurements include arsenic, barium, beryllium, cadmium, chromium, lead, selenium, silver

${ }^{* *}$ Measurements include reanalysis 
Table B.1-6

Radiological Completeness Measurements for CAU 322

\begin{tabular}{|c|c|c|c|c|c|c|}
\hline Completeness Parameters & $\begin{array}{c}\text { Gamma } \\
\text { Spectroscopy }\end{array}$ & $\begin{array}{l}\text { Isotopic } \\
\text { Uranium }\end{array}$ & $\begin{array}{l}\text { Isotopic } \\
\text { Plutonium }\end{array}$ & Strontium-90 & $\begin{array}{c}\text { Gross } \\
\text { Alpha/Beta }\end{array}$ & Tritium \\
\hline \multicolumn{7}{|c|}{ Sample Analysis Completeness } \\
\hline $\begin{array}{l}\text { Total Samples Sent to } \\
\text { Laboratory }\end{array}$ & 117 & 116 & 120 & 116 & 67 & 63 \\
\hline Total Samples Analyzed & 117 & 116 & 120 & 116 & 67 & 63 \\
\hline $\begin{array}{l}\text { Total Samples Not Analyzed } \\
\text { by the Laboratory }\end{array}$ & 0 & 0 & 0 & 0 & 0 & 0 \\
\hline Percent Completeness & 100 & 100 & 100 & 100 & 100 & 100 \\
\hline \multicolumn{7}{|c|}{ Measurement Usability Completeness } \\
\hline Total Measurements * & 2,574 & 348 & 240 & 116 & 134 & 63 \\
\hline $\begin{array}{l}\text { Total Measurements } \\
\text { Rejected - Field }\end{array}$ & 0 & 0 & 0 & 0 & 0 & 0 \\
\hline $\begin{array}{l}\text { Total Measurements } \\
\text { Rejected - Lab/Matrix }\end{array}$ & 0 & 0 & 0 & 0 & 0 & 0 \\
\hline Percent Completeness & 100 & 100 & 100 & 100 & 100 & 100 \\
\hline
\end{tabular}

${ }^{*}$ Measurements include reanalyses

In accordance with Table 6-1 of the CAU 322 CAIP, 80 percent of CAS-specific non-critical samples and analyses required valid results and 90 percent of CAS-specific critical parameters required valid results.

A measure of completeness is the amount of data that are judged to be valid. Percent completeness for sample analyses was determined by dividing the total number of samples analyzed (per method) by the total number of samples sent to the laboratory and multiplied by 100 . Percent completeness for measurement usability (not rejected) was determined by dividing the total number of nonrejected measurements by the total number measurements (per method) and multiplied by 100 . All measurements for completeness include reanalyses. Table B.1-5 and Table B.1-6 contain results of completeness per analytical method.

The specified sampling locations were used as planned and all samples were collected as specified in the CAU 322 CAIP (NNSA/NSO, 2003). 


\section{B.1.3.1 Completeness Summary}

As shown in Table B.1-5 and Table B.1-6, completeness objectives for this CAU have been achieved. Completeness for chemical analyses were 97.5 percent or better. Completeness for radiochemical analyses were 100 percent. Rejected data have been thoroughly reviewed and questions concerning these data have been addressed on a CAS-by-CAS basis. Rejected data have been determined to have no affect on closure decisions for this CAU. Overall, measurements and sampling completeness criteria have been satisfied for the CAU 322 CAI.

\section{B.1.4 Rejected Data}

\section{CAS 01-25-01, AST - Rejected Data}

Table B.1-7 contains the rejected results analytical results for CAS 01-25-01. The results for several of the late eluting polycyclics are rejected for samples 322A001 and 322A003. These results are rejected due to interference from the high level of TPH-DRO found in the samples. Based on the nature of the site and process knowledge, these analytes were not expected to be present and they were not detected above the MRL in any of the samples collected at this site. Therefore, there is no reason to believe that the absence of this data has any adverse affect on the corrective action decision.

\section{CAS 03-25-03, AST and Mud Plant - Rejected Data}

Table B.1-8 contains the rejected results per analytical method for CAS 03-25-03. As with the samples from CAS 01-25-01, the rejected late eluting polycyclics were rejected owing to the presence of TPH-DRO, which interferes with the latter portion of the chromatogram for SVOCs. This is true for all CAS 03-25-03 samples except for 322B034, which is due to low recovery of the internal standard related to the late eluting polycyclics only. Based on the nature of the site and process knowledge, these analytes were not expected to be present and they were not detected above the MRL in any of the samples collected at this site. Therefore, there is no reason to believe that the absence of this data has any adverse affect on the corrective action decision. 
Table B.1-7

CAU 322 Rejected Data at CAS 01-25-01, AST

\begin{tabular}{|c|c|c|c|}
\hline $\begin{array}{l}\text { Sample } \\
\text { Number }\end{array}$ & $\begin{array}{l}\text { Laboratory } \\
\text { Method }\end{array}$ & Parameter & $\begin{array}{c}\text { Sample } \\
\text { Matrix }\end{array}$ \\
\hline 322A001 & SW8270 & Benzo(A)Pyrene & $\overline{\text { Soil }}$ \\
\hline $322 \mathrm{~A} 001$ & SW8270 & Benzo(B)Fluoranthene & Soil \\
\hline $322 \mathrm{~A} 001$ & SW8270 & Benzo(G,H,I)Perylene & Soil \\
\hline $322 \mathrm{~A} 001$ & SW8270 & Benzo(K)Fluoranthene & Soil \\
\hline $322 \mathrm{~A} 001$ & SW8270 & Dibenzo(A,H)Anthracene & Soil \\
\hline $322 \mathrm{~A} 001$ & SW8270 & Indeno(1,2,3-CD)Pyrene & Soil \\
\hline $322 \mathrm{~A} 003$ & SW8270 & Indeno(1,2,3-CD)Pyrene & Soil \\
\hline $322 \mathrm{~A} 003$ & SW8270 & Benzo(A)Pyrene & Soil \\
\hline $322 \mathrm{~A} 003$ & SW8270 & Benzo(B)Fluoranthene & Soil \\
\hline $322 \mathrm{~A} 003$ & SW8270 & Benzo(G,H,I)Perylene & Soil \\
\hline $322 \mathrm{~A} 003$ & SW8270 & Benzo(K)Fluoranthene & Soil \\
\hline $322 \mathrm{~A} 003$ & SW8270 & Dibenzo $(\mathrm{A}, \mathrm{H})$ Anthracene & Soil \\
\hline $322 \mathrm{~A} 004$ & SW8270 & Benzo(A)Pyrene & Soil \\
\hline $322 \mathrm{~A} 004$ & SW8270 & Benzo(B)Fluoranthene & Soil \\
\hline $322 \mathrm{~A} 004$ & SW8270 & Benzo(G,H,I)Perylene & Soil \\
\hline $322 \mathrm{~A} 004$ & SW8270 & Benzo(K)Fluoranthene & Soil \\
\hline $322 \mathrm{~A} 004$ & SW8270 & Dibenzo(A,H)Anthracene & Soil \\
\hline $322 \mathrm{~A} 004$ & SW8270 & Indeno(1,2,3-CD)Pyrene & Soil \\
\hline $322 \mathrm{~A} 005$ & SW8270 & Dibenzo(A,H)Anthracene & Soil \\
\hline $322 \mathrm{~A} 005$ & SW8270 & Benzo(A)Pyrene & Soil \\
\hline $322 \mathrm{~A} 005$ & SW8270 & Benzo(B)Fluoranthene & Soil \\
\hline $322 \mathrm{~A} 005$ & SW8270 & Benzo(G,H,I)Perylene & Soil \\
\hline $322 \mathrm{~A} 005$ & SW8270 & Benzo(K)Fluoranthene & Soil \\
\hline $322 \mathrm{~A} 005$ & SW8270 & Indeno(1,2,3-CD)Pyrene & Soil \\
\hline
\end{tabular}


Table B.1-8

CAU 322 Rejected Data at CAS 03-25-03, Mud Plant AST Diesel Release (Page 1 of 2)

\begin{tabular}{|c|c|c|c|}
\hline Sample Number & Laboratory Method & Parameter & Sample Matrix \\
\hline 322B010 & SW8270 & $\overline{\text { Benzo(B)Fluoranthene }}$ & $\overline{\overline{\text { Soil }}}$ \\
\hline 322B010 & SW8270 & Benzo(K)Fluoranthene & Soil \\
\hline 322B010 & SW8270 & Benzo(G,H,I)Perylene & Soil \\
\hline 322B010 & SW8270 & Dibenzo $(\mathrm{A}, \mathrm{H})$ Anthracene & Soil \\
\hline 322B010 & SW8270 & Indeno(1,2,3-CD)Pyrene & Soil \\
\hline 322B010 & SW8270 & Benzo(A)Pyrene & Soil \\
\hline 322B012 & SW8270 & Dibenzo $(\mathrm{A}, \mathrm{H})$ Anthracene & Soil \\
\hline 322B012 & SW8270 & Indeno(1,2,3-CD)Pyrene & Soil \\
\hline 322B012 & SW8270 & Benzo(G,H,I)Perylene & Soil \\
\hline 322B012 & SW8270 & Benzo(A)Pyrene & Soil \\
\hline 322B012 & SW8270 & Benzo(B)Fluoranthene & Soil \\
\hline 322B012 & SW8270 & Benzo(K)Fluoranthene & Soil \\
\hline 322B014 & SW8270 & Benzo(G,H,I)Perylene & Soil \\
\hline 322B014 & SW8270 & Benzo(A)Pyrene & Soil \\
\hline 322B014 & SW8270 & Benzo(B)Fluoranthene & Soil \\
\hline 322B014 & SW8270 & Benzo(K)Fluoranthene & Soil \\
\hline 322B014 & SW8270 & Dibenzo(A,H)Anthracene & Soil \\
\hline 322B014 & SW8270 & Indeno(1,2,3-CD)Pyrene & Soil \\
\hline 322B015 & SW8270 & Benzo(A)Pyrene & Soil \\
\hline 322B015 & SW8270 & Benzo(B)Fluoranthene & Soil \\
\hline 322B015 & SW8270 & Benzo(G,H,I)Perylene & Soil \\
\hline 322B015 & SW8270 & Benzo(K)Fluoranthene & Soil \\
\hline 322B015 & SW8270 & Dibenzo(A,H)Anthracene & Soil \\
\hline 322B015 & SW8270 & Indeno(1,2,3-CD)Pyrene & Soil \\
\hline 322B020 & SW8270 & Benzo(A)Pyrene & Soil \\
\hline 322B020 & SW8270 & 3,3'-Dichlorobenzidine & Soil \\
\hline 322B020 & SW8270 & Benzo(A)Anthracene & Soil \\
\hline 322B020 & SW8270 & Benzo(B)Fluoranthene & Soil \\
\hline $322 \mathrm{~B} 020$ & SW8270 & Benzo(G,H,I)Perylene & Soil \\
\hline 322B020 & SW8270 & Benzo(K)Fluoranthene & Soil \\
\hline 322B020 & SW8270 & Di-N-Octyl Phthalate & Soil \\
\hline 322B020 & SW8270 & Butyl Benzyl Phthalate & Soil \\
\hline 322B020 & SW8270 & Dibenzo(A,H)Anthracene & Soil \\
\hline 322B020 & SW8270 & Indeno(1,2,3-CD)Pyrene & Soil \\
\hline
\end{tabular}


Table B.1-8

CAU 322 Rejected Data at CAS 03-25-03, Mud Plant AST Diesel Release (Page 2 of 2)

\begin{tabular}{|c|c|c|c|}
\hline Sample Number & Laboratory Method & Parameter & Sample Matrix \\
\hline 322B020 & SW8270 & Chrysene & Soil \\
\hline 322B034 & SW8270 & Benzo(A)Pyrene & Soil \\
\hline 322B034 & SW8270 & Benzo(B)Fluoranthene & Soil \\
\hline 322B034 & SW8270 & Benzo(G,H,I)Perylene & Soil \\
\hline 322B034 & SW8270 & Benzo(K)Fluoranthene & Soil \\
\hline 322B034 & SW8270 & Dibenzo(A,H)Anthracene & Soil \\
\hline 322B034 & SW8270 & Indeno(1,2,3-CD)Pyrene & Soil \\
\hline 322B053 & SW8270 & Chrysene & Soil \\
\hline 322B053 & SW8270 & Pyrene & Soil \\
\hline 322B053 & SW8270 & Dibenzo(A,H)Anthracene & Soil \\
\hline 322B053 & SW8270 & Benzo(A)Pyrene & Soil \\
\hline 322B053 & SW8270 & Benzo(A)Anthracene & Soil \\
\hline 322B053 & SW8270 & Benzo(B)Fluoranthene & Soil \\
\hline 322B053 & SW8270 & Benzo(G,H,I)Perylene & Soil \\
\hline 322B053 & SW8270 & Benzo(K)Fluoranthene & Soil \\
\hline 322B053 & SW8270 & Di-N-Octyl Phthalate & Soil \\
\hline 322B053 & SW8270 & 3,3'-Dichlorobenzidine & Soil \\
\hline 322B053 & SW8270 & Butyl Benzyl Phthalate & Soil \\
\hline 322B053 & SW8270 & Indeno(1,2,3-CD)Pyrene & Soil \\
\hline 322B053 & SW8270 & Bis(2-Ethylhexyl)Phthalate & Soil \\
\hline 322B062 & SW8270 & Benzo(B)Fluoranthene & Soil \\
\hline 322B062 & SW8270 & Benzo(G,H,I)Perylene & Soil \\
\hline 322B062 & SW8270 & Benzo(K)Fluoranthene & Soil \\
\hline 322B062 & SW8270 & Indeno(1,2,3-CD)Pyrene & Soil \\
\hline 322B062 & SW8270 & Dibenzo(A,H)Anthracene & Soil \\
\hline 322B062 & SW8270 & Benzo(A)Pyrene & Soil \\
\hline
\end{tabular}




\section{CAS 03-20-05, Injection Wells - Rejected Data}

Table B.1-9 contains the rejected analytical results for CAS 03-20-05. Results for the late eluting polycyclic SVOCs were rejected in the samples listed in Table B.1-9 due to the presence of TPH-DRO, which routinely interferes with these analytes. Several VOC results were rejected in sample 322C019 due to extremely low area counts for some of the internal standards. The low area counts for the internal standards are possibly due to matrix interference, as identified in the data validation process, and due to the presence of very high levels of TPH-DRO $(35,000 \mathrm{mg} / \mathrm{kg})$, phthalates, and a level of Aroclor-1254 above its PAL. Because the low area counts for the internal standard translate into inflated values (or at least, accurate values in the event that the target analytes are affected similarly) for these target analytes and there were no detectable concentrations of these VOCs in the sample, the rejected data has no adverse affect on the corrective action decision. Also these analytes were not expected to be present and they were not detected above the MRL (except for bis(2-ethylhexyl)phthalate) in any of the samples collected at this site. Bis(2-ethylhexyl)phthalate was detected above the MRL but well below the PAL in two samples. Therefore, there is no reason to believe that the absence of this data has any adverse affect on the corrective action decision.

Aroclor results for samples 322C039, 322C040, 322C041, 322C054L, and 322C055L were rejected due to an extremely low surrogate standard recovery. However, all of these samples are liquids which is a sample matrix in which the recovery of the surrogate decachlorobiphenyl rarely is within acceptable recovery windows. True to the nature of their associated surrogate standard, the presence of Aroclors in liquid samples is not favored physically or chemically, as reflected in their octanol-water partition coefficients, which are some of the highest measured. The liquid samples, except for sample 322C041, were all collected from contained wastes; therefore, there is no concern that the rejected PCB data for these samples would impact decisions on corrective actions for environmental soil contamination. Sample 322C041 was collected from the bottom of the injection well. Soil samples collected from the same horizon did not indicate any PCB contamination above PALs. Therefore, there is no reason to believe that the absence of this data has any adverse affect on the corrective action decision. 
Table B.1-9

CAU 322 Rejected Data at CAS 03-20-05, Injection Well (Page 1 of 9)

\begin{tabular}{|c|c|c|c|}
\hline Sample Number & Laboratory Method & Parameter & Sample Matrix \\
\hline $322 \mathrm{C010}$ & SW8270 & Benzo(A)Pyrene & Soil \\
\hline $322 \mathrm{C010}$ & SW8270 & Dibenzo(A,H)Anthracene & Soil \\
\hline $322 \mathrm{C} 010$ & SW8270 & Indeno(1,2,3-CD)Pyrene & Soil \\
\hline $322 \mathrm{C} 010$ & SW8270 & Benzo(B)Fluoranthene & Soil \\
\hline $322 \mathrm{C} 010$ & SW8270 & Benzo(G,H,I)Perylene & Soil \\
\hline $322 \mathrm{C} 010$ & SW8270 & Benzo(K)Fluoranthene & Soil \\
\hline $322 \mathrm{C} 016$ & SW8270 & Benzo(A)Anthracene & Soil \\
\hline $322 \mathrm{C} 016$ & SW8270 & Pyrene & Soil \\
\hline $322 \mathrm{C} 016$ & SW8270 & Chrysene & Soil \\
\hline $322 \mathrm{C} 016$ & SW8270 & Benzo(A)Pyrene & Soil \\
\hline $322 \mathrm{C} 016$ & SW8270 & Benzo(B)Fluoranthene & Soil \\
\hline $322 \mathrm{C} 016$ & SW8270 & Benzo(G,H,I)Perylene & Soil \\
\hline $322 \mathrm{C} 016$ & SW8270 & Benzo(K)Fluoranthene & Soil \\
\hline $322 \mathrm{C} 016$ & SW8270 & Di-N-Octyl Phthalate & Soil \\
\hline $322 \mathrm{C} 016$ & SW8270 & 3,3'-Dichlorobenzidine & Soil \\
\hline $322 \mathrm{C} 016$ & SW8270 & Butyl Benzyl Phthalate & Soil \\
\hline $322 \mathrm{C} 016$ & SW8270 & Dibenzo(A,H)Anthracene & Soil \\
\hline $322 \mathrm{C} 016$ & SW8270 & Indeno(1,2,3-CD)Pyrene & Soil \\
\hline $322 \mathrm{C} 017$ & SW8270 & Indeno(1,2,3-CD)Pyrene & Soil \\
\hline $322 \mathrm{C} 017$ & SW8270 & Butyl Benzyl Phthalate & Soil \\
\hline $322 \mathrm{C} 017$ & SW8270 & Dibenzo(A,H)Anthracene & Soil \\
\hline $322 \mathrm{C} 017$ & SW8270 & Bis(2-Ethylhexyl)Phthalate & Soil \\
\hline $322 \mathrm{C} 017$ & SW8270 & Benzo(A)Anthracene & Soil \\
\hline $322 \mathrm{C} 017$ & SW8270 & Pyrene & Soil \\
\hline $322 \mathrm{C} 017$ & SW8270 & Chrysene & Soil \\
\hline $322 \mathrm{C} 017$ & SW8270 & Benzo(B)Fluoranthene & Soil \\
\hline $322 \mathrm{C} 017$ & SW8270 & Benzo(G,H,I)Perylene & Soil \\
\hline $322 \mathrm{C} 017$ & SW8270 & Benzo(K)Fluoranthene & Soil \\
\hline $322 \mathrm{C} 017$ & SW8270 & Benzo(A)Pyrene & Soil \\
\hline $322 \mathrm{C} 017$ & SW8270 & Di-N-Octyl Phthalate & Soil \\
\hline $322 \mathrm{C} 017$ & SW8270 & 3,3'-Dichlorobenzidine & Soil \\
\hline $322 \mathrm{C} 018$ & SW8270 & Benzo(A)Pyrene & Soil \\
\hline $322 \mathrm{C} 018$ & SW8270 & Benzo(A)Anthracene & Soil \\
\hline $322 \mathrm{C} 018$ & SW8270 & Benzo(B)Fluoranthene & Soil \\
\hline
\end{tabular}


Table B.1-9

CAU 322 Rejected Data at CAS 03-20-05, Injection Well (Page 2 of 9 )

\begin{tabular}{|c|c|c|c|}
\hline Sample Number & Laboratory Method & Parameter & Sample Matrix \\
\hline 322C018 & SW8270 & Benzo(G,H,I)Perylene & Soil \\
\hline $322 \mathrm{C018}$ & SW8270 & Benzo(K)Fluoranthene & Soil \\
\hline $322 \mathrm{C} 018$ & SW8270 & Di-N-Octyl Phthalate & Soil \\
\hline $322 \mathrm{C} 018$ & SW8270 & 3,3'-Dichlorobenzidine & Soil \\
\hline $322 \mathrm{C} 018$ & SW8270 & Butyl Benzyl Phthalate & Soil \\
\hline $322 \mathrm{C} 018$ & SW8270 & Dibenzo(A,H)Anthracene & Soil \\
\hline $322 \mathrm{C} 018$ & SW8270 & Indeno(1,2,3-CD)Pyrene & Soil \\
\hline $322 \mathrm{C} 018$ & SW8270 & Bis(2-Ethylhexyl)Phthalate & Soil \\
\hline $322 \mathrm{C} 018$ & SW8270 & Pyrene & Soil \\
\hline $322 \mathrm{C} 018$ & SW8270 & Chrysene & Soil \\
\hline 322C019 & SW8270 & 4-Nitrophenol & Soil \\
\hline $322 \mathrm{C} 019$ & SW8270 & Benzo(A)Anthracene & Soil \\
\hline 322C019 & SW8270 & Benzo(K)Fluoranthene & Soil \\
\hline 322C019 & SW8270 & Benzo(B)Fluoranthene & Soil \\
\hline $322 \mathrm{C} 019$ & SW8270 & Benzo(G,H,I)Perylene & Soil \\
\hline 322C019 & SW8260 & P-Isopropyltoluene & Soil \\
\hline 322C019 & SW8260 & 1,2-Dichlorobenzene & Soil \\
\hline $322 \mathrm{C} 019$ & SW8260 & 1,3-Dichlorobenzene & Soil \\
\hline $322 \mathrm{C} 019$ & SW8260 & 1,4-Dichlorobenzene & Soil \\
\hline 322C019 & SW8260 & Hexachlorobutadiene & Soil \\
\hline $322 \mathrm{C019}$ & SW8260 & 1,2,3-Trichlorobenzene & Soil \\
\hline $322 \mathrm{C} 019$ & SW8260 & 1,2,3-Trichloropropane & Soil \\
\hline $322 \mathrm{C} 019$ & SW8260 & 1,2,4-Trichlorobenzene & Soil \\
\hline $322 \mathrm{C} 019$ & SW8260 & 1,2,4-Trimethylbenzene & Soil \\
\hline $322 \mathrm{C} 019$ & SW8260 & 1,3,5-Trimethylbenzene & Soil \\
\hline 322C019 & SW8260 & Bromobenzene & Soil \\
\hline 322C019 & SW8260 & 1,1,2,2-Tetrachloroethane & Soil \\
\hline 322C019 & SW8260 & 1,2-Dibromo-3-Chloropropane & Soil \\
\hline $322 \mathrm{C} 019$ & SW8260 & N-Butylbenzene & Soil \\
\hline 322C019 & SW8260 & 2-Chlorotoluene & Soil \\
\hline 322C019 & SW8260 & 4-Chlorotoleuene & Soil \\
\hline 322C019 & SW8260 & N-Propylbenzene & Soil \\
\hline $322 \mathrm{C} 019$ & SW8260 & Tert-Butylbenzene & Soil \\
\hline 322C019 & SW8270 & Di-N-Octyl Phthalate & Soil \\
\hline
\end{tabular}


Table B.1-9

CAU 322 Rejected Data at CAS 03-20-05, Injection Well (Page 3 of 9 )

\begin{tabular}{|c|c|c|c|}
\hline Sample Number & Laboratory Method & Parameter & Sample Matrix \\
\hline 322C019 & SW8270 & 3,3'-Dichlorobenzidine & Soil \\
\hline $322 \mathrm{C019}$ & SW8270 & Butyl Benzyl Phthalate & Soil \\
\hline $322 \mathrm{C} 019$ & SW8270 & Dibenzo(A,H)Anthracene & Soil \\
\hline $322 \mathrm{C} 019$ & SW8270 & Indeno(1,2,3-CD)Pyrene & Soil \\
\hline $322 \mathrm{C} 019$ & SW8270 & Benzo(A)Pyrene & Soil \\
\hline 322C019 & SW8260 & Sec-Butylbenzene & Soil \\
\hline 322C019 & SW8270 & Pyrene & Soil \\
\hline $322 \mathrm{C} 019$ & SW8270 & Chrysene & Soil \\
\hline $322 \mathrm{C} 020$ & SW8270 & Pyrene & Soil \\
\hline $322 \mathrm{C} 020$ & SW8270 & Chrysene & Soil \\
\hline $322 \mathrm{C020}$ & SW8270 & Bis(2-Ethylhexyl)Phthalate & Soil \\
\hline $322 \mathrm{C} 020$ & SW8270 & Benzo(G,H,I)Perylene & Soil \\
\hline $322 \mathrm{C} 020$ & SW8270 & Benzo(K)Fluoranthene & Soil \\
\hline $322 \mathrm{C} 020$ & SW8270 & Di-N-Octyl Phthalate & Soil \\
\hline $322 \mathrm{C} 020$ & SW8270 & 3,3'-Dichlorobenzidine & Soil \\
\hline $322 \mathrm{C0} 20$ & SW8270 & Butyl Benzyl Phthalate & Soil \\
\hline $322 \mathrm{C} 020$ & SW8270 & Dibenzo(A,H)Anthracene & Soil \\
\hline $322 \mathrm{C} 020$ & SW8270 & Indeno(1,2,3-CD)Pyrene & Soil \\
\hline $322 \mathrm{C} 020$ & SW8270 & Benzo(A)Pyrene & Soil \\
\hline $322 \mathrm{C} 020$ & SW8270 & Benzo(A)Anthracene & Soil \\
\hline $322 \mathrm{C020}$ & SW8270 & Benzo(B)Fluoranthene & Soil \\
\hline $322 \mathrm{C} 021$ & SW8270 & Bis(2-Ethylhexyl)Phthalate & Soil \\
\hline $322 \mathrm{C} 021$ & SW8270 & Pyrene & Soil \\
\hline $322 \mathrm{C} 021$ & SW8270 & Chrysene & Soil \\
\hline $322 \mathrm{C} 021$ & SW8270 & Benzo(A)Pyrene & Soil \\
\hline $322 \mathrm{C} 021$ & SW8270 & Benzo(A)Anthracene & Soil \\
\hline $322 \mathrm{C} 021$ & SW8270 & Dibenzo(A,H)Anthracene & Soil \\
\hline $322 \mathrm{C} 021$ & SW8270 & Benzo(B)Fluoranthene & Soil \\
\hline $322 \mathrm{C} 021$ & SW8270 & Benzo(G,H,I)Perylene & Soil \\
\hline $322 \mathrm{C} 021$ & SW8270 & Benzo(K)Fluoranthene & Soil \\
\hline $322 \mathrm{C} 021$ & SW8270 & Di-N-Octyl Phthalate & Soil \\
\hline $322 \mathrm{C} 021$ & SW8270 & 3,3'-Dichlorobenzidine & Soil \\
\hline $322 \mathrm{C} 021$ & SW8270 & Butyl Benzyl Phthalate & Soil \\
\hline $322 \mathrm{C} 021$ & SW8270 & Indeno(1,2,3-CD)Pyrene & Soil \\
\hline
\end{tabular}


Table B.1-9

CAU 322 Rejected Data at CAS 03-20-05, Injection Well (Page 4 of 9)

\begin{tabular}{|c|c|c|c|}
\hline Sample Number & Laboratory Method & Parameter & Sample Matrix \\
\hline 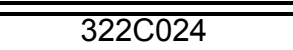 & SW8270 & Dibenzo(A,H)Anthracene & 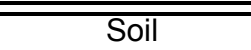 \\
\hline $322 \mathrm{C} 024$ & SW8270 & Pyrene & Soil \\
\hline $322 \mathrm{C} 024$ & SW8270 & Benzo(G,H,I)Perylene & Soil \\
\hline $322 \mathrm{C} 024$ & SW8270 & Di-N-Octyl Phthalate & Soil \\
\hline $322 \mathrm{C} 024$ & SW8270 & 3,3'-Dichlorobenzidine & Soil \\
\hline $322 \mathrm{C} 024$ & SW8270 & Butyl Benzyl Phthalate & Soil \\
\hline $322 \mathrm{C} 024$ & SW8270 & Indeno(1,2,3-CD)Pyrene & Soil \\
\hline $322 \mathrm{C} 024$ & SW8270 & Benzo(A)Pyrene & Soil \\
\hline $322 \mathrm{C} 024$ & SW8270 & Benzo(A)Anthracene & Soil \\
\hline $322 \mathrm{C} 024$ & SW8270 & Benzo(K)Fluoranthene & Soil \\
\hline $322 \mathrm{C} 024$ & SW8270 & Benzo(B)Fluoranthene & Soil \\
\hline $322 \mathrm{C} 024$ & SW8270 & Chrysene & Soil \\
\hline $322 \mathrm{C029}$ & SW8270 & Benzo(A)Anthracene & Soil \\
\hline $322 \mathrm{C029}$ & SW8270 & Benzo(B)Fluoranthene & Soil \\
\hline $322 C 029$ & SW8270 & Benzo(G,H,I)Perylene & Soil \\
\hline $322 \mathrm{C029}$ & SW8270 & Benzo(K)Fluoranthene & Soil \\
\hline $322 \mathrm{C029}$ & SW8270 & Di-N-Octyl Phthalate & Soil \\
\hline $322 \mathrm{C} 029$ & SW8270 & 3,3'-Dichlorobenzidine & Soil \\
\hline $322 C 029$ & SW8270 & Butyl Benzyl Phthalate & Soil \\
\hline $322 \mathrm{C} 029$ & SW8270 & Dibenzo(A,H)Anthracene & Soil \\
\hline $322 \mathrm{C} 029$ & SW8270 & Indeno(1,2,3-CD)Pyrene & Soil \\
\hline $322 \mathrm{C029}$ & SW8270 & Pyrene & Soil \\
\hline $322 \mathrm{C029}$ & SW8270 & Chrysene & Soil \\
\hline $322 \mathrm{C029}$ & SW8270 & Benzo(A)Pyrene & Soil \\
\hline $322 C 029$ & SW8270 & Bis(2-Ethylhexyl)Phthalate & Soil \\
\hline $322 \mathrm{C} 030$ & SW8270 & Dibenzo(A,H)Anthracene & Soil \\
\hline $322 \mathrm{C0} 30$ & SW8270 & Indeno(1,2,3-CD)Pyrene & Soil \\
\hline $322 \mathrm{C0} 30$ & SW8270 & Benzo(A)Pyrene & Soil \\
\hline $322 \mathrm{C0} 030$ & SW8270 & Benzo(B)Fluoranthene & Soil \\
\hline $322 \mathrm{C0} 030$ & SW8270 & Benzo(G,H,I)Perylene & Soil \\
\hline $322 \mathrm{C} 030$ & SW8270 & Benzo(K)Fluoranthene & Soil \\
\hline $322 \mathrm{C} 037$ & SW8270 & Benzo(A)Anthracene & Soil \\
\hline $322 \mathrm{C} 037$ & SW8270 & Benzo(G,H,I)Perylene & Soil \\
\hline $322 \mathrm{C} 037$ & SW8270 & Benzo(K)Fluoranthene & Soil \\
\hline
\end{tabular}


Table B.1-9

CAU 322 Rejected Data at CAS 03-20-05, Injection Well (Page 5 of 9 )

\begin{tabular}{|c|c|c|c|}
\hline Sample Number & Laboratory Method & Parameter & Sample Matrix \\
\hline 322C037 & SW8270 & Di-N-Octyl Phthalate & Soil \\
\hline $322 \mathrm{C037}$ & SW8270 & 3,3'-Dichlorobenzidine & Soil \\
\hline $322 \mathrm{C} 037$ & SW8270 & Butyl Benzyl Phthalate & Soil \\
\hline $322 \mathrm{C} 037$ & SW8270 & Dibenzo(A,H)Anthracene & Soil \\
\hline $322 \mathrm{C} 037$ & SW8270 & Indeno(1,2,3-CD)Pyrene & Soil \\
\hline $322 \mathrm{C} 037$ & SW8270 & Benzo(B)Fluoranthene & Soil \\
\hline $322 \mathrm{C} 037$ & SW8270 & Benzo(A)Pyrene & Soil \\
\hline $322 \mathrm{C} 037$ & SW8270 & Pyrene & Soil \\
\hline $322 \mathrm{C} 037$ & SW8270 & Chrysene & Soil \\
\hline $322 \mathrm{C038}$ & SW8270 & Benzo(B)Fluoranthene & Soil \\
\hline $322 \mathrm{C038}$ & SW8270 & Benzo(G,H,I)Perylene & Soil \\
\hline $322 \mathrm{C} 038$ & SW8270 & Benzo(K)Fluoranthene & Soil \\
\hline $322 \mathrm{C} 038$ & SW8270 & Di-N-Octyl Phthalate & Soil \\
\hline $322 \mathrm{C038}$ & SW8270 & 3,3'-Dichlorobenzidine & Soil \\
\hline $322 \mathrm{C} 038$ & SW8270 & Butyl Benzyl Phthalate & Soil \\
\hline $322 \mathrm{C0} 038$ & SW8270 & Indeno(1,2,3-CD)Pyrene & Soil \\
\hline $322 \mathrm{C} 038$ & SW8270 & Pyrene & Soil \\
\hline $322 \mathrm{C038}$ & SW8270 & Chrysene & Soil \\
\hline $322 \mathrm{C} 038$ & SW8270 & Dibenzo(A,H)Anthracene & Soil \\
\hline $322 \mathrm{C} 038$ & SW8270 & Benzo(A)Pyrene & Soil \\
\hline $322 \mathrm{C038}$ & SW8270 & Benzo(A)Anthracene & Soil \\
\hline $322 \mathrm{C} 091$ & SW8270 & Pyrene & Soil \\
\hline 322C091 & SW8270 & Chrysene & Soil \\
\hline 322C091 & SW8270 & Benzo(A)Pyrene & Soil \\
\hline $322 \mathrm{C} 091$ & SW8270 & Bis(2-Ethylhexyl)Phthalate & Soil \\
\hline 322C091 & SW8270 & Benzo(A)Anthracene & Soil \\
\hline 322C091 & SW8270 & Benzo(B)Fluoranthene & Soil \\
\hline 322C091 & SW8270 & Benzo(G,H,I)Perylene & Soil \\
\hline $322 \mathrm{C} 091$ & SW8270 & Benzo(K)Fluoranthene & Soil \\
\hline 322C091 & SW8270 & Di-N-Octyl Phthalate & Soil \\
\hline $322 \mathrm{C} 091$ & SW8270 & 3,3'-Dichlorobenzidine & Soil \\
\hline $322 \mathrm{C} 091$ & SW8270 & Butyl Benzyl Phthalate & Soil \\
\hline $322 \mathrm{C} 091$ & SW8270 & Dibenzo(A,H)Anthracene & Soil \\
\hline 322C091 & SW8270 & Indeno(1,2,3-CD)Pyrene & Soil \\
\hline
\end{tabular}


Table B.1-9

CAU 322 Rejected Data at CAS 03-20-05, Injection Well (Page 6 of 9)

\begin{tabular}{|c|c|c|c|}
\hline Sample Number & Laboratory Method & Parameter & Sample Matrix \\
\hline $322 \mathrm{C092}$ & SW8270 & Chyrsene & Soil \\
\hline $322 \mathrm{C092}$ & SW8270 & Pyrene & Soil \\
\hline 322C092 & SW8270 & Benzo(A)Pyrene & Soil \\
\hline $322 \mathrm{C} 092$ & SW8270 & Benzo(A)Anthracene & Soil \\
\hline $322 \mathrm{C} 092$ & SW8270 & Benzo(B)Fluoranthene & Soil \\
\hline 322C092 & SW8270 & Benzo(G,H,I)Perylene & Soil \\
\hline 322C092 & SW8270 & Benzo(K)Fluoranthene & Soil \\
\hline 322C092 & SW8270 & Di-N-Octyl Phthalate & Soil \\
\hline 322C092 & SW8270 & 3,3'-Dichlorobenzidine & Soil \\
\hline $322 \mathrm{C} 092$ & SW8270 & Butyl Benzyl Phthalate & Soil \\
\hline 322C092 & SW8270 & Dibenzo(A,H)Anthracene & Soil \\
\hline $322 \mathrm{C} 092$ & SW8270 & Indeno(1,2,3-CD)Pyrene & Soil \\
\hline 322C092 & SW8270 & Bis(2-Ethylhexyl)Phthalate & Soil \\
\hline $322 \mathrm{C093}$ & SW8270 & Bis(2-Ethylhexyl)Phthalate & Soil \\
\hline $322 \mathrm{C} 093$ & SW8270 & Chyrsene & Soil \\
\hline $322 \mathrm{C} 093$ & SW8270 & Benzo(B)Fluoranthene & Soil \\
\hline $322 \mathrm{C093}$ & SW8270 & Benzo(G,H,I)Perylene & Soil \\
\hline $322 \mathrm{C} 093$ & SW8270 & Benzo(K)Fluoranthene & Soil \\
\hline $322 \mathrm{C} 093$ & SW8270 & Di-N-Octyl Phthalate & Soil \\
\hline $322 \mathrm{C} 093$ & SW8270 & 3,3'-Dichlorobenzidine & Soil \\
\hline $322 \mathrm{C093}$ & SW8270 & Butyl Benzyl Phthalate & Soil \\
\hline $322 \mathrm{C093}$ & SW8270 & Dibenzo(A,H)Anthracene & Soil \\
\hline $322 \mathrm{C} 093$ & SW8270 & Indeno(1,2,3-CD)Pyrene & Soil \\
\hline $322 \mathrm{C} 093$ & SW8270 & Pyrene & Soil \\
\hline $322 \mathrm{C} 093$ & SW8270 & Benzo(A)Pyrene & Soil \\
\hline $322 \mathrm{C093}$ & SW8270 & Benzo(A)Anthracene & Soil \\
\hline $322 \mathrm{C} 101$ & SW8270 & Benzo(B)Fluoranthene & Soil \\
\hline $322 \mathrm{C} 101$ & SW8270 & Pyrene & Soil \\
\hline $322 \mathrm{C} 101$ & SW8270 & Chrysene & Soil \\
\hline 322C101 & SW8270 & Benzo(A)Pyrene & Soil \\
\hline $322 \mathrm{C} 101$ & SW8270 & Benzo(A)Anthracene & Soil \\
\hline $322 \mathrm{C} 101$ & SW8270 & Benzo(G,H,I)Perylene & Soil \\
\hline $322 \mathrm{C} 101$ & SW8270 & Benzo(K)Fluoranthene & Soil \\
\hline $322 \mathrm{C} 101$ & SW8270 & 3,3'-Dichlorobenzidine & Soil \\
\hline
\end{tabular}


Table B.1-9

CAU 322 Rejected Data at CAS 03-20-05, Injection Well (Page 7 of 9 )

\begin{tabular}{|c|c|c|c|}
\hline Sample Number & Laboratory Method & Parameter & Sample Matrix \\
\hline $322 \mathrm{C} 101$ & SW8270 & Butyl Benzyl Phthalate & Soil \\
\hline $322 \mathrm{C} 101$ & SW8270 & Dibenzo(A,H)Anthracene & Soil \\
\hline $322 \mathrm{C} 101$ & SW8270 & Indeno(1,2,3-CD)Pyrene & Soil \\
\hline 322C101 & SW8270 & Bis(2-Ethylhexyl)Phthalate & Soil \\
\hline $322 \mathrm{C} 101$ & SW8270 & Di-N-Octyl Phthalate & Soil \\
\hline $322 \mathrm{C} 022$ & SW8270 & 3,3'-Dichlorobenzidine & Liquid \\
\hline $322 \mathrm{C} 022$ & SW8270 & Butyl Benzyl Phthalate & Liquid \\
\hline $322 \mathrm{C} 022$ & SW8270 & Dibenzo(A,H)Anthracene & Liquid \\
\hline $322 \mathrm{C} 022$ & SW8270 & Indeno(1,2,3-CD)Pyrene & Liquid \\
\hline $322 \mathrm{C} 022$ & SW8270 & Benzo(A)Pyrene & Liquid \\
\hline $322 \mathrm{C} 022$ & SW8270 & Benzo(A)Anthracene & Liquid \\
\hline $322 \mathrm{C} 022$ & SW8270 & Benzo(G,H,I)Perylene & Liquid \\
\hline $322 \mathrm{C} 022$ & SW8270 & Benzo(K)Fluoranthene & Liquid \\
\hline $322 \mathrm{C} 022$ & SW8270 & Di-N-Octyl Phthalate & Liquid \\
\hline $322 \mathrm{C} 022$ & SW8270 & Pyrene & Liquid \\
\hline $322 \mathrm{C} 022$ & SW8270 & Chrysene & Liquid \\
\hline $322 \mathrm{C} 022$ & SW8270 & Benzo(B)Fluoranthene & Liquid \\
\hline $322 \mathrm{C} 023$ & SW8270 & Benzo(A)Pyrene & Liquid \\
\hline $322 \mathrm{C} 023$ & SW8270 & Di-N-Octyl Phthalate & Liquid \\
\hline $322 \mathrm{C} 023$ & SW8270 & 3,3'-Dichlorobenzidine & Liquid \\
\hline $322 \mathrm{C} 023$ & SW8270 & Butyl Benzyl Phthalate & Liquid \\
\hline $322 \mathrm{C023}$ & SW8270 & Dibenzo(A,H)Anthracene & Liquid \\
\hline $322 \mathrm{C} 023$ & SW8270 & Indeno(1,2,3-CD)Pyrene & Liquid \\
\hline $322 \mathrm{C} 023$ & SW8270 & Bis(2-Ethylhexyl)Phthalate & Liquid \\
\hline $322 \mathrm{C} 023$ & SW8270 & Benzo(A)Anthracene & Liquid \\
\hline $322 \mathrm{C} 023$ & SW8270 & Benzo(B)Fluoranthene & Liquid \\
\hline $322 \mathrm{C} 023$ & SW8270 & Benzo(G,H,I)Perylene & Liquid \\
\hline $322 \mathrm{C} 023$ & SW8270 & Benzo(K)Fluoranthene & Liquid \\
\hline $322 \mathrm{C} 023$ & SW8270 & Pyrene & Liquid \\
\hline $322 \mathrm{C} 023$ & SW8270 & Chrysene & Liquid \\
\hline $322 C 039$ & SW8082 & Aroclor 1016 & Liquid \\
\hline $322 C 039$ & SW8082 & Aroclor 1221 & Liquid \\
\hline $322 \mathrm{C} 039$ & SW8082 & Aroclor 1232 & Liquid \\
\hline $322 \mathrm{C} 039$ & SW8082 & Aroclor 1242 & Liquid \\
\hline
\end{tabular}


Table B.1-9

CAU 322 Rejected Data at CAS 03-20-05, Injection Well

(Page 8 of 9)

\begin{tabular}{|c|c|c|c|}
\hline Sample Number & Laboratory Method & Parameter & Sample Matrix \\
\hline $322 C 039$ & SW8082 & Aroclor 1260 & Liquid \\
\hline $322 C 039$ & SW8082 & Aroclor 1248 & Liquid \\
\hline $322 C 039$ & SW8270 & Pyrene & Liquid \\
\hline $322 C 039$ & SW8270 & Chrysene & Liquid \\
\hline $322 C 039$ & SW8270 & Benzo(B)Fluoranthene & Liquid \\
\hline $322 C 039$ & SW8270 & Benzo(G,H,I)Perylene & Liquid \\
\hline $322 C 039$ & SW8270 & Benzo(K)Fluoranthene & Liquid \\
\hline $322 C 039$ & SW8270 & Di-N-Octyl Phthalate & Liquid \\
\hline $322 C 039$ & SW8270 & 3,3'-Dichlorobenzidine & Liquid \\
\hline $322 C 039$ & SW8270 & Butyl Benzyl Phthalate & Liquid \\
\hline $322 C 039$ & SW8270 & Dibenzo(A,H)Anthracene & Liquid \\
\hline $322 C 039$ & SW8270 & Indeno(1,2,3-CD)Pyrene & Liquid \\
\hline $322 C 039$ & SW8270 & Benzo(A)Pyrene & Liquid \\
\hline $322 C 039$ & SW8270 & Benzo(A)Anthracene & Liquid \\
\hline $322 \mathrm{C040}$ & SW8270 & Benzo(A)Anthracene & Liquid \\
\hline $322 \mathrm{C040}$ & SW8082 & Aroclor-1221 & Liquid \\
\hline $322 \mathrm{C040}$ & SW8270 & Benzo(B)Fluoranthene & Liquid \\
\hline $322 \mathrm{C040}$ & SW8270 & Benzo(G,H,I)Perylene & Liquid \\
\hline $322 \mathrm{C040}$ & SW8270 & Benzo(K)Fluoranthene & Liquid \\
\hline $322 \mathrm{C040}$ & SW8082 & Aroclor 1016 & Liquid \\
\hline $322 \mathrm{C040}$ & SW8082 & Aroclor 1232 & Liquid \\
\hline $322 \mathrm{C040}$ & SW8082 & Aroclor 1242 & Liquid \\
\hline $322 \mathrm{C040}$ & SW8082 & Aroclor 1260 & Liquid \\
\hline $322 \mathrm{C040}$ & SW8270 & Di-N-Octyl Phthalate & Liquid \\
\hline $322 \mathrm{C040}$ & SW8082 & Aroclor 1248 & Liquid \\
\hline $322 \mathrm{C040}$ & SW8270 & 3,3'-Dichlorobenzidine & Liquid \\
\hline $322 \mathrm{C040}$ & SW8270 & Butyl Benzyl Phthalate & Liquid \\
\hline $322 \mathrm{C040}$ & SW8270 & Pyrene & Liquid \\
\hline $322 \mathrm{C040}$ & SW8270 & Chrysene & Liquid \\
\hline $322 \mathrm{C} 040$ & SW8270 & Dibenzo(A,H)Anthracene & Liquid \\
\hline $322 \mathrm{C040}$ & SW8270 & Indeno(1,2,3-CD)Pyrene & Liquid \\
\hline $322 \mathrm{C040}$ & SW8270 & Benzo(A)Pyrene & Liquid \\
\hline $322 \mathrm{C} 041$ & SW8270 & Benzo(B)Fluoranthene & Liquid \\
\hline $322 \mathrm{C} 041$ & SW8270 & Benzo(G,H,I)Perylene & Liquid \\
\hline
\end{tabular}


Table B.1-9

CAU 322 Rejected Data at CAS 03-20-05, Injection Well (Page 9 of 9 )

\begin{tabular}{|c|c|c|c|}
\hline Sample Number & Laboratory Method & Parameter & Sample Matrix \\
\hline $322 \mathrm{C} 041$ & SW8270 & Benzo(K)Fluoranthene & Liquid \\
\hline $322 \mathrm{C} 041$ & SW8270 & Dibenzo(A,H)Anthracene & Liquid \\
\hline $322 \mathrm{C} 041$ & SW8270 & Indeno(1,2,3-CD)Pyrene & Liquid \\
\hline $322 \mathrm{C} 041$ & SW8270 & Benzo(A)Pyrene & Liquid \\
\hline 322C054L & SW8082 & Aroclor 1260 & Liquid \\
\hline 322C054L & SW8082 & Aroclor 1016 & Liquid \\
\hline 322C054L & SW8082 & Aroclor 1221 & Liquid \\
\hline 322C054L & SW8082 & Aroclor 1232 & Liquid \\
\hline 322C054L & SW8082 & Aroclor 1242 & Liquid \\
\hline 322C054L & SW8082 & Aroclor 1248 & Liquid \\
\hline 322C054L & SW8082 & Aroclor 1254 & Liquid \\
\hline 322C055L & SW8082 & Aroclor 1016 & Liquid \\
\hline $322 \mathrm{C055L}$ & SW8082 & Aroclor 1221 & Liquid \\
\hline 322C055L & SW8082 & Aroclor 1232 & Liquid \\
\hline 322C055L & SW8082 & Aroclor 1242 & Liquid \\
\hline 322C055L & SW8082 & Aroclor 1248 & Liquid \\
\hline 322C055L & SW8082 & Aroclor 1260 & Liquid \\
\hline $322 \mathrm{C} 055 \mathrm{~L}$ & SW8082 & Aroclor 1254 & Liquid \\
\hline $322 \mathrm{C} 054 \mathrm{O}$ & SW8270 & Benzo(K)Fluoranthene & Oil \\
\hline $322 \mathrm{C} 054 \mathrm{O}$ & SW8270 & Benzo(A)Pyrene & Oil \\
\hline $322 \mathrm{C} 054 \mathrm{O}$ & SW8270 & Benzo(B)Fluoranthene & Oil \\
\hline $322 \mathrm{C} 054 \mathrm{O}$ & SW8270 & Benzo(G,H,I)Perylene & Oil \\
\hline $322 \mathrm{C054O}$ & SW8270 & Dibenzo(A,H)Anthracene & Oil \\
\hline $322 \mathrm{C054O}$ & SW8270 & Indeno(1,2,3-CD)Pyrene & Oil \\
\hline $322 \mathrm{C} 055 \mathrm{O}$ & SW8270 & Benzo(A)Pyrene & Oil \\
\hline $322 \mathrm{C} 055 \mathrm{O}$ & SW8270 & Benzo(K)Fluoranthene & Oil \\
\hline $322 \mathrm{C} 055 \mathrm{O}$ & SW8270 & Dibenzo(A,H)Anthracene & Oil \\
\hline $322 \mathrm{C} 055 \mathrm{O}$ & SW8270 & Indeno(1,2,3-CD)Pyrene & Oil \\
\hline $322 \mathrm{C055O}$ & SW8270 & Benzo(G,H,I)Perylene & Oil \\
\hline $322 \mathrm{C055O}$ & SW8270 & Benzo(B)Fluoranthene & Oil \\
\hline
\end{tabular}




\section{B.1.5 Representativeness}

Representativeness is a qualitative evaluation of measurement system performance. It is the degree to which sample data accurately and precisely represents a characteristic of a population, parameter variations at a sampling point, or an environmental condition (EPA, 1996). Representativeness is assured by a carefully developed sampling strategy, collecting a specified number of samples from proper sampling locations, and analyzing them by approved analytical methods.

\section{B.1.6 Comparability}

Field sampling, as described in the CAU 322 CAIP (NNSA/NSO, 2003), was performed and documented in accordance with approved procedures that are comparable to standard industry practices. Approved analytical methods and procedures were used to analyze, report, and validate the data. These are comparable to other methods used not only in industry and government practices, but most importantly are comparable to other investigations conducted for the NTS. Therefore, datasets within this project are considered comparable to other datasets generated using these same standardized DOE procedures, thereby meeting DQO requirements.

In addition, the use of standard, approved field and analytical methods ensured that data were appropriate for comparison to the investigation action levels specified in the CAIP.

\section{B.1.7 Reconciliation of Conceptual Site Models to the Data}

This section provides a reconciliation of the data collected and analyzed during this investigation with the CSMs established in the DQO process.

\section{B.1.7.1 Conceptual Site Models}

Two CSMs were developed for the CAU 322 CASs as presented in the CAIP (NNSA/NSO, 2003). The CSMs were based on historical information and process knowledge. Each CSM is discussed in the following sections. In some instances, both CSMs apply to several of the CAU 322 CASs. 


\section{B.1.7.1.1 Leakage or Spilling from ASTs and Associated Processes Conceptual Site Model}

This section describes CSM elements for CAU 322 CASs designated as leakage or spilling from equipment and stored materials. The following CASs are included in this category:

- $01-25-01$

- 03-25-03, Areas A and B

The primary source of potential contamination for the CASs listed above is associated with the potential releases of contaminants to the surface soil surrounding and/or below storage containers as a result of leakage and overfilling of both ASTs and vehicles fueled from these ASTs. Therefore, the general CSM included soil potentially impacted by surface release of contaminants. The mechanisms for this type of release include both designed (e.g., surface discharge point) and/or accidental (e.g., filling spillage, container leakage) releases. This model assumed that any contamination would be concentrated in the soil located immediately beneath and adjacent to the system component (e.g., storage containers, transfer lines). The extent of underlying soil impact is expected to be variable and is dependent upon the volume of effluent released, system design, geologic conditions, nature of COPCs, and other factors. The CSM and system configurations were consistent with those provided in the CAIP (NNSA/NSO, 2003).

\section{B.1.7.1.2 Injection Wells and Associated Soils Conceptual Site Model}

This section describes CSM elements for CAU 322 CASs designated as injection wells and associated soils. The following CAS is included in this category:

$$
\text { - } 03-20-05
$$

The primary source of potential contamination for the CAS listed above is associated with the potential releases of effluent to the soil surrounding or the subsurface below the facilities and/or injection wells. Therefore, the general CSM included soil potentially impacted by subsurface release (via holding tank and injection well) and surface release (via lateral movement along the concrete floors) of effluent. The mechanisms for this type of release include both designed (e.g., surface discharge point) and accidental (e.g., leakage) releases. This model assumed that any contamination would migrate away from the release point, primarily downward, and to a lesser degree horizontally. 
The highest concentration of contaminants would be located in the immediate vicinity of a subsurface release, and would decrease with distance, both horizontally and vertically. The extent of soil impact (underlying and lateral) is expected to be variable and is dependent upon the volume of effluent released, system design, geologic conditions, nature of COPCs, and other factors. The CSM and system configurations were consistent with those provided in the CAIP (NNSA/NSO, 2003).

\section{B.1.7.2 Contaminant Nature and Extent}

The presence of contamination was identified by sample results showing COPC soil concentrations exceeding the PALs identified in the CAIP, thereby defining COCs at the CASs. In general, soil sample results demonstrated that the vertical and lateral extent of COCs was limited to the physical boundaries of the CSMs defined in the CAIP (NNSA/NSO, 2003). Field screening was conducted and samples were collected at locations to bound contaminated areas with results below action levels. This confirmed that the extent of contamination was limited to regions defined by the CAS-specific CSMs. The CAS-specific investigation findings, analytical results, and descriptions of site conditions are presented in Appendix A.

\section{B.1.8 Conclusions}

Samples were collected and analyzed as planned and within acceptable performance limits, except as specified in Section B.1.4. The DQIs have been met; therefore, the DQO objectives related to data quality have been satisfied. 


\section{B.2.0 References}

EPA, see U.S. Environmental Protection Agency.

NNSA/NSO, see U.S. Department of Energy, National Nuclear Security Administration Nevada Site Office.

U.S. Department of Energy, National Nuclear Security Administration Nevada Site Office. 2003. Corrective Action Investigation Plan for Corrective Action Unit 322: Areas 1 and 3 Release Sites and Injection Wells, Nevada Test Site, Nevada. Las Vegas, NV.

U.S. Environmental Protection Agency. 1994. Contract Laboratory Program National Functional Guidelines for Inorganic Data Review, EPA/540/R-94/013. Washington, DC.

U.S. Environmental Protection Agency. 1996. Test Methods for Evaluating Solid Waste, Physical/Chemical Methods, SW-846, 3rd Edition, CD-ROM PB97-501928GEI. Washington, DC. 


\section{Appendix C \\ Cost Estimates for CAU 322}

(6 Pages) 
EST ID: CAU 322

COST ESTIMATE PROPOSAL DATA SHEET

Date:

30-Nov-04

CAS 01-25-01

TO: Glenn Richardson

FROM: Charles Denson

SUBJECT: CADD Alternative Cost Estimates for CAU-322: Area 1 and 3 Release Sites and

Injection Wells, NTS

ESTIMATOR: Charles Denson

REF \#:

TYPE OF ESTIMATE:

$\mathbf{X}$

ORDER OF MAGNITUDE

PRELIMINARY / PLANNING / STUDY

CONCEPTUAL / BUDGET

TITLE I

BECHTEL NEVADA

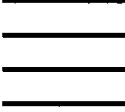

TYPE OF WORK:

PROJECT WORK SCOPE IS EXPECTED TO BE PERFORMED BY:

DOE PRIME (LUMP SUM)

BN CONSTRUCTION

BN MAINTENANCE
SUBCONTRACT

OTHER

\section{STATEMENT OF WORK}

This estimate has been prepared to provide remedial alternative costs for the closure of Corrective Action Site (CAS) 01-25-01, which is included within Corrective Action Unit (CAU) 322. CAU 322 CAS 01-25-01 is an environmental restoration site listed in the Federal Facility Agreement and Consent Order (FFACO). CAS 01-25-01 described within the FFACO as the Area 1 AST Release is at the top edge of a bluff overlooking the Area 1 Shaker Plant. Two alternatives have been evaluated for closure of the CAS: Alternative I. No Further Action and Alternative III. Closure in Place with Administrative Controls. Alternative II. Clean Closure is not feasible due to physical access restrictions and safety considerations. This estimate will be used to identify the most cost effective alternative for closure of the site while remaining protective of human health and the environment. The total estimated costs are intended for comparative analysis of remedial fieldwork cost only. Cost for project management, plan preparation, project support and/or other activities are not included herein.

\section{SCOPE:}

Provide site closure using one of the following alternatives:

I) NO FURTHER ACTION

II) CLEAN CLOSURE BY EXCAVATION AND REMOVAL

III) CLOSURE IN PLACE WITH ADMINISTRATIVE CONTROLS

\section{BASIS:}

The characterization contractor recently completed field measurements within a gravel containment pit that detected elevated TPH at various depths within the subsurface. The gravel containment pit was constructed to hold an aboveground storage tank that is believed to have stored diesel fuel for the Area 1 Shaker Plant. A site closure estimate for the closure in place alternative was priced using standard construction references such as RS Means, Richardson's, and the BN estimating database. An estimate for clean closure was not developed because the site location posed access restrictions and compromised a safe working environment to perform a cleanup action. There is no estimate required for evaluation of the No Further Action alternative since no cost is incurred.

\section{ALTERNATIVE SPECIFIC BASIS OF ESTIMATE/ASSUMPTIONS}

Alternative I: No Further Action

Alternative II: Clean Closure

- None.

Alternative III: Closure in Place with Administrative Controls

- Implement and install administrative controls.

- Develop and document appropriate use restrictions. 


\section{ASSUMPTIONS:}

- No corrective actions are required for the surrounding areas outside the CAS boundary.

- The COC's discovered during the site investigation only include TPH-DRO.

- Clean Closure is not a preferred option due to access restrictions and safety considerations.

- There will be no surface impediments.

- No radiological COCs were discovered at this CAS.

- All COCs at the site have been identified during the site investigation and analytical data accurately represents site conditions and waste characteristics.

- Equipment will be available and remain operational to support the planned/scheduled completion of each CADD alternative.

- Work to be performed by BN during a "normal" workday (no provision for overtime has been provided). Shifts are based on 10-hour days / 4-days per week.

- This estimate does not include efficiencies which may be realized if work for similar activities at similar sites can be completed concurrently.

- This estimate does not include costs for preparation of required project plans, permits, reports, mobilization and demobilization, site preparations, or project management.

- Dimensions, waste volumes, measurements, and analytical data provided by the characterization contractor accurately represent site conditions and waste characteristics.

\section{ESCALATION:}

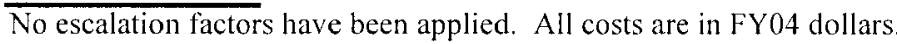

\section{CONTINGENCY:}

Contingency costs are not included in this estimate.

\section{RATES:}

Rates are based on FY04 Final rates (Rev 4) effective 7/28/04 and were applied using the BN FY04 cost model.

\section{COST ALTERNATIVES SUMMARY:}

Alternative I: No Further Action

Alternative III: Closure in Place with Administrative Controls

a. Implement and Install Administrative Controls

b. Use Restrictions, Survey, and Post Closure Care

\section{REVIEW/CONCURRENCE:}
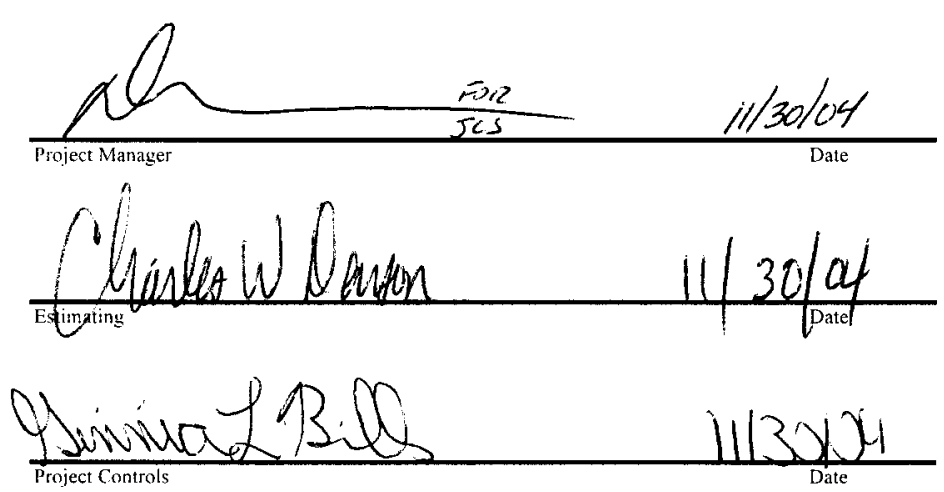
BECHTEL NEVADA

CAS 03-25-03

SUBJECT: CADD Alternative Cost Estimates for CAU-322: Area 1 and 3 Release Sites and

$$
\text { Injection Wells, NTS }
$$

ESTIMATOR: Charles Denson REF \#:

\section{TYPE OF ESTIMATE:}

$\begin{array}{ll}\mathbf{X} & \text { ORDER OF MAGNITUDE } \\ \text { PRELIMINARY / PLANNING / STUDY } \\ \text { CONCEPTUAL / BUDGET } \\ \text { TITLE I }\end{array}$

\section{PROJECT WORK SCOPE IS EXPECTED TO BE PERFORMED BY:}

\author{
DOE PRIME (LUMP SUM) \\ BN CONSTRUCTION
} BN MAINTENANCE

$-\frac{X}{-}$

\section{TITLE II}

WORK ORDER

COMPARATIVE

OTHER

\section{TYPE OF WORK:}

\begin{tabular}{ll} 
& NON-MANUAL ONLY \\
\hline $\mathbf{X} \quad$ MANUAL ONLY \\
\hline & MANUAL \& NON-MANUAL \\
& OTHER
\end{tabular}

\section{STATEMENT OF WORK}

This estimate has been prepared to provide remedial alternative costs for the closure of Corrective Action Site (CAS) 03-25-03, which is included within Corrective Action Unit (CAU) 322. CAU 322 CAS 03-25-03 is an environmental restoration site listed in the Federal Facility Agreement and Consent Order (FFACO). CAS 03-25-03 is specifically described within the FFACO as the "Mud Plant AST Diesel Release" site located within the former Area 3 Camp.

\section{SCOPE:}

Provide site closure using one of the following alternatives:

I) NO FURTHER ACTION

II) CLEAN CLOSURE BY EXCAVATION AND REMOVAL

III) CLOSURE IN PLACE WITH ADMINISTRATIVE CONTROLS

\section{BASIS:}

The characterization contractor recently completed field measurements within the surrounding areas of the Mud Plant Facility which detected elevated TPHDRO that exceeded the preliminary action level (PAL). Site closure estimates for each alternative were priced using standard construction references as RS Means, Richardson's, and the BN estimating database. There is no estimate required for evaluation of the No Further Action alternative since no cost is incurred.

\section{ALTERNATIVE SPECIFIC BASIS OF ESTIMATE/ASSUMPTIONS}

\section{Alternative II: Clean Closure}

- Excavate and transport approximately $333 \mathrm{cu}$. yds. of TPH impacted soil at Area A sampling location for disposal.

- Field Screening Analysis and Verification sampling.

- Backfill clean soil at Area A (includes a $20 \%$ expansion factor)

- Excavate and transport approximately $370 \mathrm{cu}$. yds. of TPH impacted soil at Area B sampling location for disposal.

- Field Screening Analysis and Verification sampling.

- Backfill clean soil at Area B (includes a $20 \%$ expansion factor).

- Excavate and transport approximately $889 \mathrm{cu}$. yds. of TPH impacted soil at Area C sampling location for disposal.

- Field Screening Analysis and Verification sampling.

- Backfill clean soil at Area C (includes a $20 \%$ expansion factor)

Alternative III: Closure in Place with Administrative Controls

- Implement and install administrative controls (i.e. postings, signs, fencing, etc.).

- Develop and document appropriate use restrictions.

\section{ASSUMPTIONS:}

- No corrective actions are required for the surrounding areas outside of the CAS boundary.

- Verification sampling will be performed after the field screening analysis

- Radioactive and hazardous constituents are not present in this CAS.

- Equipment will remain operational to support the planned/scheduled completion of each CADD alternative.

- Waste volumes are based on field measurements collected during the corrective action investigation and may be affected by weather events prior to completing the corrective actions. 


\section{ASSUMPTIONS - Continued:}

-Work to be performed by BN during a "normal" workday (no provision for overtime has been provided). Shifts are based on 10-hour days / 4-days per week.

- This estimate does not include the efficiencies which may be realized if work for similar activities at similar sites can be completed concurrently.

- This estimate does not include costs for preparation of required project plans, permits, reports, mobilization and demobilization, site preparations, or project management.

- A soll borrow area is located within one mile of the site

- There will be no surface impediments.

- Dimensions, waste volumes, measurements, and analytical data provided by the characterization contractor accurately represent site conditions and waste characteristics.

\section{ESCALATION:}

No escalation factors have been applied. All costs are in FY04 dollars.

\section{CONTINGENCY:}

Contingency costs are not included in this estimate.

RATES:

Rates are based on FY04 Final rates (Rev 4) effective 7/28/04 and were applied using the BN FY04 cost model.

\section{COST ALTERNATIVES SUMMARY:}

Alternative I: No Further Action

Alternative II: Clean Closure

\footnotetext{
a. Excavate and Transport TPH Impacted Soil at Area A

b. Field Screening Analysis

c. Verification Sampling

d. Backtill with Clean Soil

e. Excavate and Transport TPH Impacted Soil at Area B

f. Field Screening Analysis

g. Verification Sampling

h. Backfill with Clean Soil

I. Excavate and Transport TPH Impacted Soil at Area C

j. Field Screening Analysis

k. Verification Sampling

i. Backfill with Clean Soil
}

Alternative III Closure in Place with Administrative Controls

a. Install Administrative Controls (Postings, Signage, etc.)

d. Use Restrictions, Survey, and Post Closure Care

\section{REVIEW/CONCURRENCE:}
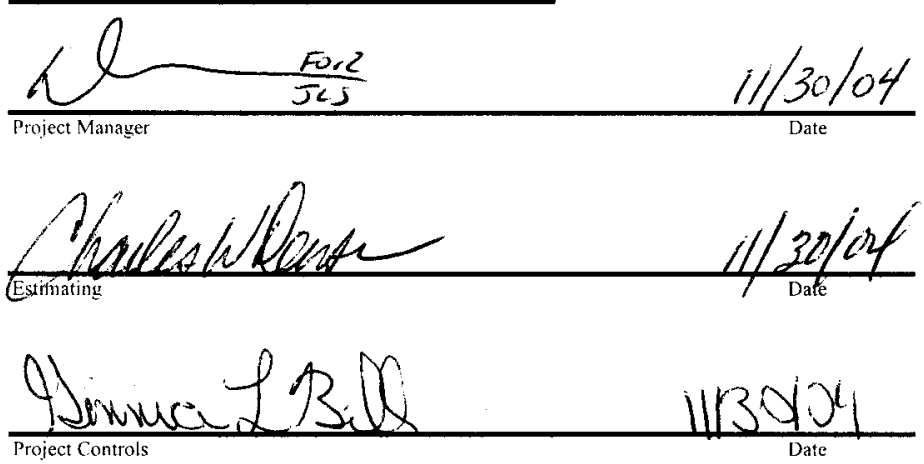
BECHTEL NEVADA

CAS 03-20-05

TO: Glenn Richardson

FROM: Charles Denson

SUBJECT: CADD Alternative Cost Estimates for CAU-322: Area 1 and 3 Release Sites and

\section{Injection Wells, NTS}

ESTIMATOR: Charles Denson

REF \#:

TYPE OF ESTIMATE:

$\mathrm{X}$ ORDER OF MAGNITUDE
PRELIMINARY / PLANNING / STUDY
CONCEPTUAL / BUDGET
TITLE I $\quad \begin{aligned} & \text { TITLE II } \\ & \text { WORK ORDER } \\ & \text { COMPARATIVE } \\ & \text { OTHER }\end{aligned}$

TYPE OF WORK:

PROJECT WORK SCOPE IS EXPECTED TO BE PERFORMED BY:

DOE PRIME (LUMP SUM)
BN CONSTRUCTION $\mathrm{X}$
BN MAINTENANCE

SUBCONTRACT

GPP

OTHER

\section{STATEMENT OF WORK}

This estimate has been prepared to provide remedial alternative costs for the closure of Corrective Action Site (CAS) 03-20-05, which is included within Corrective Action Unit (CAU) 322. CAU 322 (CAS) 03-20-05 is an environmental restoration site listed in the Federal Facility Agreement and Consent Order (FFACO). CAS 03-20-05 is specifically described within the FFACO as Area 3 Injection Wells. Three alternatives have been evaluated for closure of the CAS I. No Further Action; II. Clean Closure; and III (B) Closure in Place with Best Management Practice of Removal. This estimate will be used to identify the most cost effective alternative for closure of the site while remaining protective of human health and the environment. The total estimated costs are intended for comparative analysis of remedial fieldwork cost only. Cost for project management, plan preparation, project support, and/or other activities are not included herein.

\section{SCOPE:}

Provide site closure using one of the following alternatives:

I) NO FURTHER ACTION

II) CLEAN CLOSURE BY EXCAVATION AND REMOVAL

III(B) CLOSURE IN PLACE WITH BEST MANAGEMENT PRACTICE OF

REMOVAL

\section{BASIS:}

The characterization contractor recently completed field measurements in Area 3 of the BOP Shop Building, three below grade holding tanks, and an injection well. Therefore, each closure alternative was evaluated with a knowledge of TPH and potential mixed waste (rad and metals) on the surface and subsurface of the soil. Site closure estimates for each alternative were priced using standard construction references such as RS Means, Richardson's, and the BN estimating database. There is no estimate required for evaluation of the No Further Action alternative since no cost is incurred.

\section{ALTERNATIVE SPECIFIC BASIS OF ESTIMATE/ASSUMPTIONS}

\section{Alternative I: No Further Action}

None.

Alternative II: Clean Closure

- Not practical or feasible, primarily due to depth and volume of contamination (specifically TPH-DRO)

Alternative III (B): Closure in Place with Administrative Controls

- Remove metal casing from around the injection well.

- Remove radiological and hazardous impacted soils from the injection well casing area

- Grout the injection well casing area, applicable sumps, and the three below grade holding tanks

- Perform field screening analysis and collect verification samples.

- Backfill excavated area with clean fill material.

- Install an engineer designed concrete cover over the injection well area (if necessary)

- Waste Management and disposal.

- Perform housekeeping and debris removal (if necessary)

- Develop and implement document appropriate use restrictions.

\section{ASSUMPTIONS:}

- Mixed waste disposal is based upon the maximum value $(\$ 20 \mathrm{~K})$ for the smallest bulk volume.

- Install and engineer designed concrete cover over the injection well area if COCs other than TPH-DRO remain in the soil.

- Verification samples will be collected subseguent to field screening analyses.

- The Closure in Place Alternative with Best Management Practices includes cadmium and radiological removal activities from CAS 03-20-05. 


\section{ASSUMPTIONS: Continued}

- Assume a widespread TPH-DRO volume is $60 \mathrm{ft}$ below grade surface and originated from the injection well sump.

- The appropriate PPE will be available to support field activities (Level $\mathrm{C}$ with respirators), if necessary.

- Equipment will remain operational to support the planned/scheduled completion of each CADD alternative.

- Waste volumes are based on field measurements collected during the corrective action investigation and may be affected by weather events prior to completing the corrective actions.

- Work to be performed by BN during a "normal" workday (no provision for overtime has been provided). Shifts are based on 10-hour days / 4-days per week.

- This estimate does not include the efficiencies which may be realized if work for similar activities at similar sites can be completed concurrently.

- This estimate does not include costs for preparation of required project plans, permits, reports, or project management.

- A soil borrow area is located within one mile of the site.

- Dimensions, volumes, measurements, and analytical data provided by the characterization contractor accurately represent site conditions and waste characteristics.

\section{ESCALATION:}

No escalation factors have been applied. All costs are in FY04 dollars.

\section{CONTINGENCY:}

Contingency costs are not included in this estimate.

\section{RATES:}

Rates are based on FY04 Final rates (Rev 4) effective 7/28/04 and were applied using the BN FY04 cost model.

\section{COST ALTERNATIVES SUMMARY:}

Alternative No Further Action

\section{Alternative Clean Closure}

$$
\text { a. None. }
$$

Alternative Closure in Place with Best Management Practice of Removal

a. Removal of Metal Casing Around the Injection Well

b. Removal of Radiological and Hazardous Impacted Soils from the Injection Well Casing Area

c. Grout the injection well casing area, applicable sumps, and the three below grade holding tanks.

d. Perforn Field Screening Analysis and Collect Verification Samples

e. Backfill Excavated Area with Clean Fill

f. Install an Engineer Designed Concrete Cover

g. Housekeeping and Debris Removal

I. Use Restrictions, Survey, and Post Closure Care

\section{REVIEW/CONCURRENCE:}
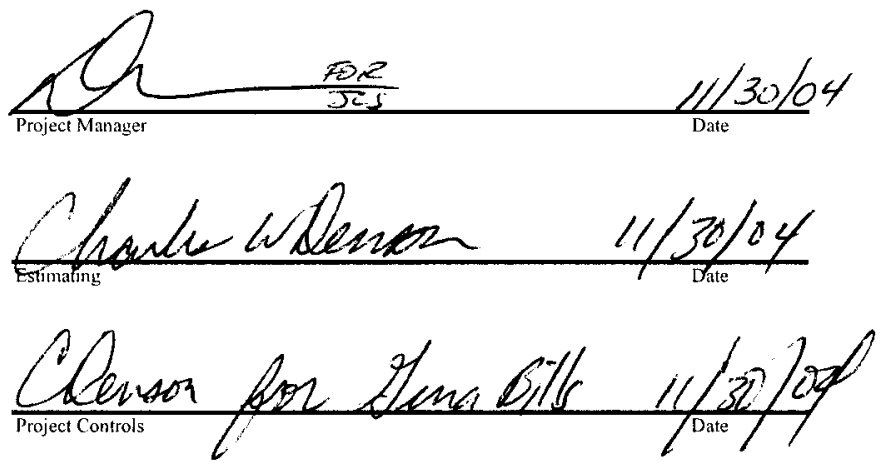


\section{Appendix D}

Sample Location Coordinates for CAU 322:

Release Sites and Injection Wells

Nevada Test Site, Nevada 


\section{D.1.0 Sample Location Coordinates}

Sample location coordinates were collected during the corrective action investigation using a Trimble GPS, Model TSCI. These coordinates identify the field sampling locations and corner points of interest at each CAS in CAU 322. Coordinates are presented in easting, northing, longitude, and latitude.

\section{D.1.1 CAS 01-25-01, AST}

Sample locations at CAS 01-25-01 are shown on Figure A.3-1. GPS coordinates for sample locations at this CAS are presented in Table D.1-1.

Table D.1-1

Sample Location GPS Coordinates for CAS 01-25-01

\begin{tabular}{||c|c|c|c|c|c|c|}
\hline Location & Latitude & Longitude & Northing & Easting & $\begin{array}{c}\text { Vertical } \\
\text { Precision }\end{array}$ & $\begin{array}{c}\text { Horizontal } \\
\text { Precision }\end{array}$ \\
\hline \hline A01 & 37.06845376 & -116.1375293 & 4102610.715 & 576673.073 & 0.7 & 0.5 \\
\hline A02 & 37.06842302 & -116.1376159 & 4102607.236 & 576668.403 & 1 & 0.6 \\
\hline A04 & 37.06834107 & -116.1375647 & 4102598.185 & 576670.041 & 1 & 0.6 \\
\hline A05 & 37.06837461 & -116.1374716 & 4102601.981 & 576678.282 & 0.7 & 0.5 \\
\hline
\end{tabular}

\section{D.1.2 CAS 03-20-03, AST and Mud Plant}

Sample locations at CAS 03-25-03 are shown on Figure A.4-1. The GPS coordinates for sample locations at this CAS are presented in Table D.1-2.

\section{D.1.3 CAS 03-20-05, Injection Wells}

Sample locations at CAS 03-20-05 are shown on Figure A.5-1. The GPS coordinates for sample locations at this CAS are presented in Table D.1-3. 
Table D.1-2

Sample Location GPS Coordinates for CAS 03-25-03

\begin{tabular}{|c|c|c|c|c|c|c|}
\hline Location & Latitude & Longitude & Northing & Easting & $\begin{array}{c}\text { Vertical } \\
\text { Precision }\end{array}$ & $\begin{array}{l}\text { Horizontal } \\
\text { Precision }\end{array}$ \\
\hline B01 & 37.04842688 & -116.0310217 & 4100480.237 & 586164.413 & 1.2 & 0.6 \\
\hline B02 & 37.0484164 & -1160309793 & 4100479.113 & 586168.19 & 0.5 & 0.3 \\
\hline B03 & 37.04848058 & -116.0309798 & 4100486.232 & 586168.071 & 0.6 & 0.4 \\
\hline B04 & 37.04834911 & -116.0309865 & 4100471.641 & 586167.629 & 0.5 & 0.3 \\
\hline B05 & 37.04828059 & -116.0309893 & 4100464.037 & 586167.457 & 1.2 & 0.5 \\
\hline B06 & 37.04839414 & -116.0308882 & 4100476.726 & 586176.321 & 1.1 & 0.5 \\
\hline B07 & 37.04839126 & -116.0308215 & 4100476.467 & 586182.252 & 1.1 & 0.5 \\
\hline B08 & 37.04823091 & -116.0295203 & 4100459.858 & 586298.143 & 1.3 & 0.6 \\
\hline B09 & 37.04833421 & -116.0294495 & 4100471.383 & 586304.325 & 0.5 & 0.5 \\
\hline B10 & 37.04841616 & -116.0295349 & 4100480.396 & 586296.639 & 1.4 & 0.7 \\
\hline B11 & 37.04845815 & -116.0294078 & 4100485.169 & 586307.886 & 0.6 & 0.5 \\
\hline B12 & 37.04845782 & -116.0294743 & 4100485.072 & 586301.979 & 0.6 & 0.5 \\
\hline $\mathrm{B} 12 \mathrm{a}$ & 37.04844471 & -116.0294685 & 4100483.623 & 586302.51 & 0.6 & 0.5 \\
\hline $\mathrm{B} 12 \mathrm{~b}$ & 37.04845842 & -116.0294863 & 4100485.129 & 586300.912 & 0.6 & 0.5 \\
\hline B12c & 37.04847208 & -116.0294598 & 4100486.667 & 586303.25 & 0.6 & 0.5 \\
\hline B13 & 37.04859613 & -116.0295816 & 4100500.319 & 586292.277 & 0.6 & 0.5 \\
\hline B14 & 37.04851552 & -116.0294073 & 4100491.534 & 586307.871 & 0.8 & 0.6 \\
\hline B15 & 37.04835596 & -116.0308687 & 4100472.508 & 586178.095 & 1.1 & 0.5 \\
\hline B16 & 37.04861207 & -116.0293464 & 4100502.301 & 586313.18 & 1.4 & 0.7 \\
\hline B17 & 37.04855336 & -116.029315 & 4100495.816 & 586316.037 & 0.6 & 0.5 \\
\hline B18 & 37.04859235 & -116.0294321 & 4100500.034 & 586305.576 & 1.4 & 0.7 \\
\hline B19 & 37.04843689 & -116.0310696 & 4100481.303 & 586160.141 & 0.6 & 0.4 \\
\hline B20 & 37.04859836 & -116.0292436 & 4100500.871 & 586322.092 & 0.6 & 0.5 \\
\hline
\end{tabular}


Table D.1-3

Sample Location GPS Coordinates for CAS 03-20-05

\begin{tabular}{|c|c|c|c|c|c|c|}
\hline Location & Latitude & Longitude & Northing & Easting & $\begin{array}{c}\text { Vertical } \\
\text { Precision }\end{array}$ & $\begin{array}{l}\text { Horizontal } \\
\text { Precision }\end{array}$ \\
\hline$\overline{\mathrm{C} 01}$ & 37.03552661 & -116.0362324 & 4099044.426 & 585744.236 & 1.6 & 0.8 \\
\hline $\mathrm{C02}$ & 37.03555515 & -116.0360989 & 4099047.712 & 585727.387 & 1.8 & 0.7 \\
\hline $\mathrm{CO3}$ & 37.03563503 & -116.0362272 & 4099056.458 & 585715.891 & 1.2 & 1.7 \\
\hline C04 & 37.03553034 & -116.035967 & 4099045.079 & 585739.153 & 1 & 0.5 \\
\hline $\mathrm{C05}$ & 37.0356082 & -116.0331417 & 4099053.713 & 585728.097 & 0.9 & 0.5 \\
\hline $\mathrm{C06}$ & 37.03553421 & -116.035922 & 4099045.549 & 585743.149 & 0.9 & 0.5 \\
\hline $\mathrm{C07}$ & 37.03553782 & -116.0359095 & 4099045.96 & 585744.256 & 0.9 & 0.4 \\
\hline C08 & 37.03556487 & -116.0359094 & 4099048.962 & 585744.236 & 1.5 & 0.7 \\
\hline C09 & 37.03560893 & -116.0360609 & 4099053.713 & 585730.706 & 1.2 & 0.4 \\
\hline C10 & 37.03566205 & -116.0362694 & 4099059.418 & 585712.107 & 1.4 & 0.7 \\
\hline C11 & 37.03559942 & -116.0358967 & 4099052.805 & 585745.328 & 1.5 & 0.7 \\
\hline C12 & 37.03547621 & -116.035873 & 4099039.159 & 585747.568 & 1.6 & 0.7 \\
\hline C13 & 37.0355826 & -116.0359239 & 4099050.915 & 585742.924 & 1.5 & 0.7 \\
\hline C14 & 37.0355596 & -116.0359389 & 4099048.35 & 585741.619 & 1.6 & 0.7 \\
\hline C15 & 37.03564998 & -116.0360898 & 4099058.241 & 585728.097 & 1.7 & 0.9 \\
\hline C16 & 37.03563683 & -116.0360567 & 4099056.812 & 585731.056 & 1.7 & 0.9 \\
\hline C17 & 37.0355853 & -116.0360423 & 4099051.108 & 585732.387 & 1.1 & 0.6 \\
\hline C18 & 37.03555982 & -116.0358941 & 4099048.415 & 585745.604 & 1.5 & 0.7 \\
\hline C19 & 37.0355415 & -116.0361236 & 4099046.325 & 585743.149 & 1 & 0.5 \\
\hline
\end{tabular}




\section{Appendix E}

Evaluation of Risk 


\section{E.1.0 Evaluation of Risk}

The proposed corrective action alternative for CASs 01-25-01, AST Release, 03-25-03 Mud Plant AST Diesel Release (Area B), and 03-20-05, Injection Wells results in TPH-DRO remaining in the soil at concentrations exceeding PALs. An evaluation of risk for TPH in soil at these CASs is presented in the following sections.

\section{E.1.1 Human Health Screening}

A human health screening evaluation is used in this analysis to identify the risk to human receptors from TPH levels in the soil present at CASs 01-25-01, 03-25-03, and 03-20-05. The TPH contamination was evaluated by comparing actual contaminant levels in the surface and subsurface soils to screening level concentrations for contaminants in soil. The sample results above PALs for TPH-DRO are shown in Table A.3-4, Table A.4-7, and Table A.5-6 of Appendix A. The highest levels that will remain in soil after recommended corrective actions are 7,000 $\mathrm{mg} / \mathrm{kg}$ for CAS 01-25-01; 23,000 mg/kg for CAS 03-25-03; and 1,800 for CAS 03-20-05.

The TPH action level is defined in the Nevada Administrative Code (NAC, 2003) as $100 \mathrm{mg} / \mathrm{kg}$. The Massachusetts Department of Environmental Protection (MADEP) has issued risk-based guidance for the screening of petroleum contaminated sites (MADEP, 2002). The guidance, developed by MADEP, includes three levels of cleanup standards including a generic soil cleanup standard designed to be protective at most sites (i.e., it does not consider site-specific factors). This generic standard was developed using a series of conservative site scenarios to evaluate risks to human health, public welfare, and the environment via a number of exposure pathways and concerns, including direct contact, ingestion, and leaching.

The MADEP generic standard has different action levels based on site-specific factors for exposure to soil and groundwater (MADEP, 2002). For purposes of this evaluation, the low risk scenario for soil exposure (i.e., "isolated soils, and/or soils where the frequency and/or intensity of exposure is low.") and the least restrictive risk scenario for groundwater exposure were selected to support the recommended closure alternatives and determine the future risk to site workers. The low risk scenario for soil was chosen based on the restricted access to the NTS and implementation of 
recommended use restrictions at each of the CASs, thereby reducing the potential of future exposure. The least restrictive risk scenario for exposure to groundwater was chosen for this site based on the $\mathrm{a}-\mathrm{k}$ analysis provided in Section 3.3 of the CADD which indicates potential groundwater contamination is not a concern at any of the CAU 322 CASs. Using these criteria for the site and the TPH analytical data, the MADEP guidance document indicates a clean-up level of 5,000 micrograms per gram (which is equivalent to $5,000 \mathrm{mg} / \mathrm{kg}$ ) (MADEP, 2002). However, this level is based on the potential for a future impact to groundwater; thus, when applied to the desert environment is more conservative than initially planned by MADEP. There is no driving force that will move the contamination deeper into the soil, all potential sources are no longer present, and the depth to groundwater is at least 500 feet below the deepest contamination at any of the CASs under consideration. In addition, the contaminants under consideration (TPH-DRO) are the long-chained, heavier fraction of TPH. These long-chained hydrocarbons typically have very high adsorption coefficients and low volatility; therefore, they are considered very immobile in the unsaturated zone. Based on these factors the potential impact to groundwater and future exposure to various receptors is not considered a complete pathway and the $5,000 \mathrm{mg} / \mathrm{kg}$ action level is considered more conservative than necessary.

\section{E.1.2 Risk Evaluation}

Corrective Action Sites 01-25-01, 03-25-03, and 03-20-05 are located in Areas 1 and 3 of the NTS. The NTS is a government-controlled restricted access area that is guarded on a 24-hour, 365-day per year basis. Areas 1 and 3 are located within a nonresidential restricted use zone classified as "Nuclear and High Explosive Test Land-Use Zone" (DOE/NV, 1998). Under this land-use scenario, NNSA/NSO operations and interagency programs and operations would continue as they have in the past. Currently, there are limited activities in Areas 1 and 3 and there is no known construction scheduled in the area of these CASs. Because of the planned future land use, current institutional controls would continue. Therefore, the potential exposure to industrial or construction workers is considered minimal and is not anticipated to meet or exceed the 250 days per year, 8 -hour per day, 25 year exposure frequency suggested under the industrial or construction worker exposure scenario. These sites fall more under the limited occupancy exposure scenario of 335 hours per year for a 25-year carrier. All that is anticipated for these sites is the annual inspections and routine 
maintenance of the use restrictions. Under this scenario, the risk to future site workers is considered to be much less than what would be indicated under an industrial reuse exposure frequency.

At CAS 01-25-01 the TPH concentrations that exceed PALs are present in soils directly under the gravel surface at concentrations between 2,900 and $5,900 \mathrm{mg} / \mathrm{kg}$. The concentration of TPH-DRO in deeper soils range from $7,000 \mathrm{mg} / \mathrm{kg}$ at 2 to $3 \mathrm{ft}$ bgs to $140 \mathrm{mg} / \mathrm{kg}$ at 9 to $10 \mathrm{ft}$ bgs. The area of contamination above PALs is relatively small (i.e., approximately 1,000 $\mathrm{ft}^{2}$ ) and situated within a bermed area. The gravel cover and berms will further limit the exposure routes that may adversely impact site workers. Additionally, the site is situated adjacent to a very steep slope and located away from traffic areas. Safety considerations will also prevent any future construction or development of this site. The removal activities would present a much higher safety risk to site workers than leaving the contamination in place.

At CAS 03-25-03 the TPH contamination above PALs is present at the surface. However, the highest detected surface concentration is $370 \mathrm{mg} / \mathrm{kg}$ and is significantly less than the $5,000 \mathrm{mg} / \mathrm{kg}$ identified in the MADEP guidance (the higher concentrations of up to $23,000 \mathrm{mg} / \mathrm{kg}$ were detected at depths of between 1 and $15 \mathrm{ft}$ bgs). Additionally, the sites containing surface TPH-DRO contamination are relatively small (i.e., approximately $30 \mathrm{ft}^{2}$ total) as demonstrated by step-out sampling and situated between two CASs (CAS 03-09-06, Mud Disposal Crater and CAS 03-47-02 Mud Plant Pond) that are closed and use restricted because of TPH contamination. Because the highest concentrations of TPH identified at this site are in the subsurface, significant exposure to site workers would not occur unless intrusive activities are initiated. The use restriction and close proximity to buildings and other structures will prevent any inadvertent excavations in this area.

At CAS 03-20-05 the TPH contamination above PALs that will remain in place will be at depths greater than $10 \mathrm{ft}$ bgs. Soil above $10 \mathrm{ft}$ bgs will be removed due to lead, PCB, and radiological contamination above PALs. The highest concentrations of TPH near the surface will be removed during the proposed corrective actions. The remaining TPH contamination is less than $3,300 \mathrm{mg} / \mathrm{kg}$ which is below the $5,000 \mathrm{mg} / \mathrm{kg}$ identified in the MADEP guidance. The contaminated area has been determined to be relatively small (i.e., approximately $100 \mathrm{ft}^{2}$ ). The remaining TPH contaminated soils will be at depths greater than 10 feet. The EPA risk assessment guidance (EPA, 1991), for the construction scenario, does not consider contamination at depths greater than 10 feet because this 
exceeds the average depth of foundations or footers. The concentrations of TPH remaining at depths deeper than 10 feet would not be considered to have a complete exposure pathway under the construction scenario; thus, they would not present an unacceptable risk to human health if left in place regardless of the concentrations. The primary concern for the deep contamination is the potential impact to groundwater. This exposure route is not considered significant at the NTS because of the limited precipitation and large evapotranspiration associated with the desert climates as demonstrated in the a-k analysis. In addition to the removal of the surface contamination and the initiation of a use restriction at this CAS, the well will be grouted and sealed which will further limit the exposure routes for the residual contamination.

In summary, the size of the contaminated areas, limited access, depth of contamination, and/or safety concerns preclude the removal of TPH contamination at these three CASs In addition, the proposed land-use restrictions for each of these CASs will provide notification of the contaminates to potential site visitors and future users through site postings. This will further control potential exposures to the residual TPH-DRO.

\section{E.1.3 Uncertainty Analysis}

As with all risk evaluations there is some uncertainty in the assessment. For these sites the future use, although outlined in a DOE programatic document (DOE/NV, 1998), is subject to changes in the DOE and NTS mission. Along with this uncertainty there is the possibility that inadvertent excavations may occur at the various CAS without adhering to the use restrictions. To account for these uncertainties, the evaluations are usually based on conservative assumptions that allow for some error without increasing the real risk. Examples of conservative assumptions used in the risk assessment include:

- Risk assessment methods assume long-term exposure. Any realistic exposure scenario for these sites would be of very limited duration. The primary access to these sites would be to maintain use restriction or other limited maintenance activities. All of the sites are closed and abandoned with no planned future use for which they were constructed.

- Risk assessments assume that no controls would be used to reduce potential exposure to the contaminants. Under the system currently in place at the NTS, the use restrictions are incorporated into the Real Estate Operation Permits that are required to conduct work at any 
site throughout the NTS and since the NTS will remain an active DOE site for the foreseeable future, work on the site without appropriate controls is improbable.

- The risk assessment does consider the visual identification of the location and types of contamination present at a given facility. The posting of the sites with signs identifying the type of contamination further reduces any potential for inadvertent exposure to the contaminated soils.

\section{E.1.4 Interpretation}

Analytical TPH concentrations at discreet locations within CASs 01-25-01, 03-25-03, and 03-20-05 exceed the PAL of $100 \mathrm{mg} / \mathrm{kg}$. Although the PAL is not risk based, an additional regulatory source for risk-based screening levels for TPH (MADEP) indicates the levels of TPH that can remain at a site without causing an unacceptable risk to human health or the environment is considerably higher. The methods used to calculate this screening level assume exposure parameters that are very unlikely to occur at these sites. Residual contamination at all three CASs could pose an unacceptable risk to industrial and construction workers if allowed uncontrolled access. Site-specific considerations including relatively small areas of contamination, depth of contamination, restricted access to the NTS, limited vertical migration, and posting of signs warning of exposure hazards at each CAS, limit the potential risk of an inadvertent exposure resulting in adverse effects from these sites.

In conclusion, based on the limited lateral and vertical extent of the COCs, the access restrictions in place for the NTS, and the depth to ground water, the potential exposure to industrial and construction workers is considered extremely low and no adverse impacts should result from leaving theses COCs at the site considering the institutional controls proposed in the remedial alternative. 


\section{E.2.0 References}

DOE/NV, see U.S. Department of Energy, Nevada Operations Office.

EPA, see U.S. Environmental Protection Agency.

MADEP, see Massachusetts Department of Environmental Protection.

Massachusetts Department of Environmental Protection. 2002. Characterizing Risks Posed by Petroleum Contaminated Sites: Implementation of the MADEP VPH/EPH Approach, Final Policy, 31 October, Policy \#WSC-02-411. Boston, MA.

NAC, see Nevada Administrative Code.

Nevada Administrative Code. 2003. NAC 445A.2272, "Contamination of Soil: Establishment of Action Levels." Carson City, NV.

U.S. Department of Energy, Nevada Operations Office. 1998. Nevada Test Site Resource Management Plan, DOE/NV--518. Las Vegas, NV.

U.S. Environmental Protection Agency. 1991. Risk Assessment Guidance for Superfund: Volume 1 Human Health Evaluation Manual, Publication 9285.7-01C. 
Appendix F

Project Organization for CAU 322 


\section{F.1.0 Project Organization}

The NNSA/NSO Project Manager is Janet Appenzeller-Wing and her telephone number is (702) 295-0461.

The identification of the project Health and Safety Officer and the Quality Assurance Officer can be found in the appropriate plan. However, personnel are subject to change and it is suggested that the appropriate U.S. Department of Energy Project Manager be contacted for further information. The Task Manager will be identified in the FFACO Monthly Activity Report prior to the start of field activities. 


\section{Appendix G}

Nevada Division of Environmental Protection Comments 


\section{NEVADA ENVIRONMENTAL RESTORATION PROJECT} DOCUMENT REVIEW SHEET

\begin{tabular}{|c|c|c|c|c|c|}
\hline \multicolumn{4}{|c|}{$\begin{array}{l}\text { 1. Document Title/Number: Final Corrective Action Decision Document for Corrective Action Unit 322: Area } 1 \\
\text { and } 3 \text { Release Sites and Injection Wells, Nevada Test Site, Nevada }\end{array}$} & \multicolumn{2}{|l|}{ 2. Document Date: October 2004} \\
\hline \multicolumn{4}{|c|}{ 3. Revision Number: 0} & \multicolumn{2}{|c|}{ 4. Originator/Organization: Stoller-Navarro } \\
\hline \multicolumn{4}{|c|}{ 5. Responsible DOE/NV ERP Subproject Mgr.: Sabine Curtis } & \multicolumn{2}{|l|}{ 6. Date Comments Due: $11 / 05 / 2004$} \\
\hline \multicolumn{6}{|c|}{ 7. Review Criteria: All } \\
\hline \multicolumn{4}{|c|}{ 8. Reviewer/Organization/Phone No.: Greg Raab/NDEP (702) 486-2867 } & \multicolumn{2}{|l|}{ 9. Reviewer's Signature: } \\
\hline $\begin{array}{l}\text { 10. Comment } \\
\text { Number/ } \\
\text { Location }\end{array}$ & 11. Type ${ }^{*}$ & 12. Comment & & 13. Comment Response & 14. Accept \\
\hline $\begin{array}{l}\text { 1. Section 3.3.3.3, } \\
\text { page } 32 \text { of } 42 \text {, last } \\
\text { bullet }\end{array}$ & & $\begin{array}{l}\text { "Grouting of the injection well sump and the area within the injection } \\
\text { well vault" Although it is assumed the injection well sump is the } \\
\text { injection well, it is not clear if the grouting includes the injection well. } \\
\text { Provide clarification that they are on and the same entity. }\end{array}$ & $\begin{array}{l}\text { For clarity the I } \\
\text { follows: } \\
\text { "Grouting of th } \\
\text { Additional char } \\
\text { this paragraph }\end{array}$ & $\begin{array}{l}\text { ast bullet has been revised to read as } \\
\text { injection well" } \\
\text { ges were made to the other bullets in } \\
\text { to further clarify the actions to be taken. }\end{array}$ & \\
\hline
\end{tabular}

${ }^{a}$ Comment Types: $M=$ Mandatory, $S$ = Suggested.

Return Document Review Sheets to NNSA/NSO Environmental Restoration Division, Attn: QAC, M/S 505 


\section{Library Distribution List}

\section{$\underline{\text { Copies }}$}

U.S. Department of Energy

1 (Uncontrolled)

National Nuclear Security Administration

Nevada Site Office

Technical Library

P.O. Box 98518, M/S 505

Las Vegas, NV 89193-8518

U.S. Department of Energy

1 (Uncontrolled, electronic copy)

Office of Scientific and Technical Information

P.O. Box 62

Oak Ridge, TN 37831-0062

Southern Nevada Public Reading Facility

2 (Uncontrolled, electronic copy)

c/o Nuclear Testing Archive

P.O. Box 98521, M/S 400

Las Vegas, NV 89193-8521

Manager, Northern Nevada FFACO

2 (Uncontrolled, electronic copy)

Public Reading Facility

c/o Nevada State Library \& Archives

Carson City, NV 89701-4285 